Water Availability and Use Science Program

U.S. Geological Survey Karst Interest Group Proceedings, October 19-20, 2021

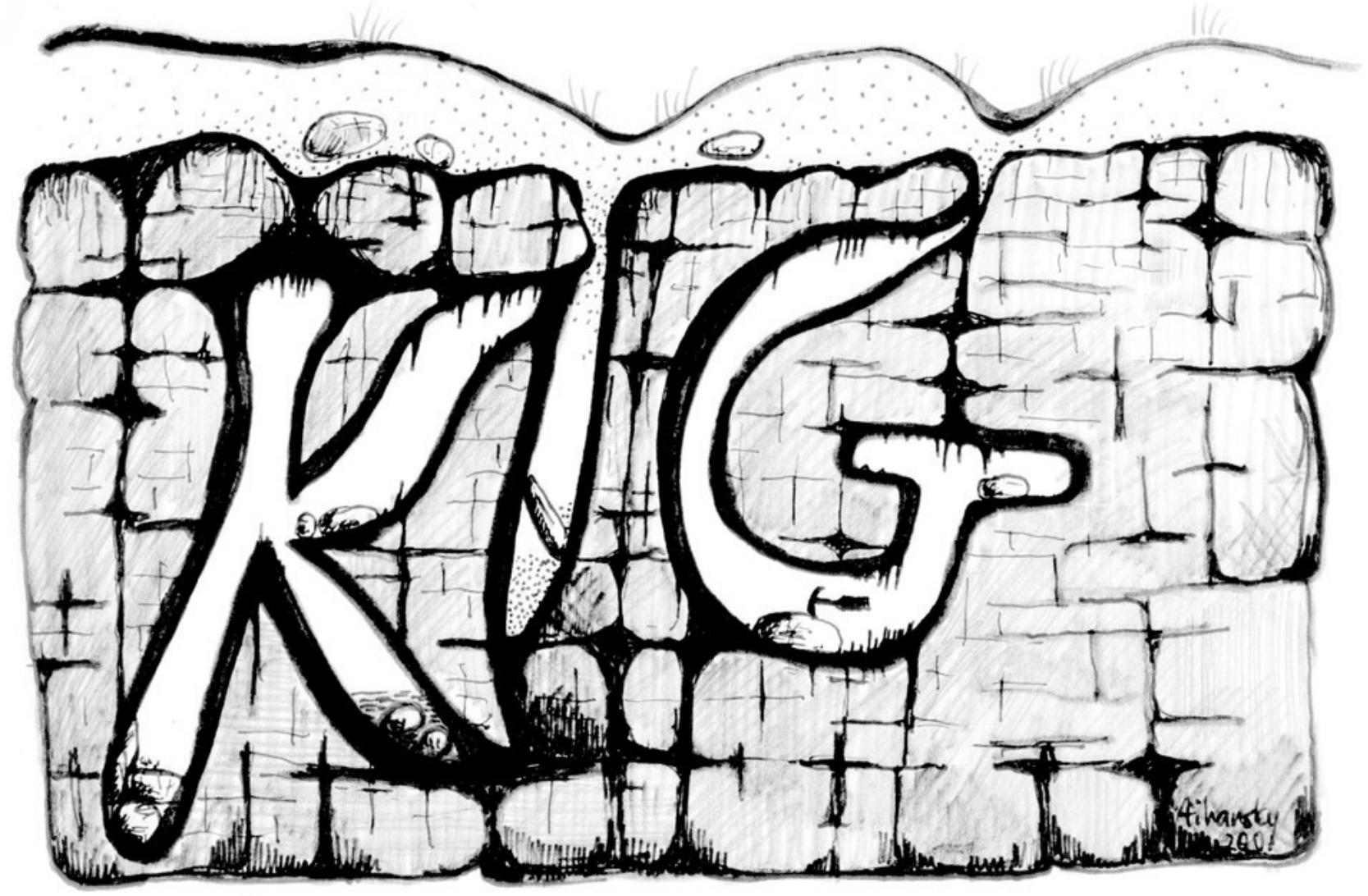

Scientific Investigations Report 2020-5019 



\section{U.S. Geological Survey Karst Interest Group Proceedings, October 19-20, 2021}

Edited by Eve L. Kuniansky and Lawrence E. Spangler

Water Availability and Use Science Program

Scientific Investigations Report 2020-5019 


\section{U.S. Geological Survey, Reston, Virginia: 2021}

For more information on the USGS - the Federal source for science about the Earth, its natural and living resources, natural hazards, and the environment-visit - or call 1-888-ASK-USGS.

For an overview of USGS information products, including maps, imagery, and publications, visit https://store.usgs.gov/.

Any use of trade, firm, or product names is for descriptive purposes only and does not imply endorsement by the U.S. Government.

Although this information product, for the most part, is in the public domain, it also may contain copyrighted materials as noted in the text. Permission to reproduce copyrighted items must be secured from the copyright owner.

Suggested citation:

Kuniansky, E.L., and Spangler, L.E., eds., 2021, U.S. Geological Survey Karst Interest Group Proceedings, October 19-20, 2021: U.S. Geological Survey Scientific Investigations Report 2020-5019, 147 p., https://doi.org/10.3133/sir20205019.

ISSN 2328-0328 (online) 


\section{Contents}

Introduction and Acknowledgments ..........................................................................................

Virtual Agenda for Online Participation, U.S. Geological Survey Karst Interest Group

Workshop, October 19-20, 2021 ........................................................................................

Original Agenda for U.S. Geological Survey Karst Interest Group Workshop, Nashville,

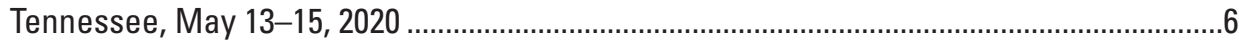

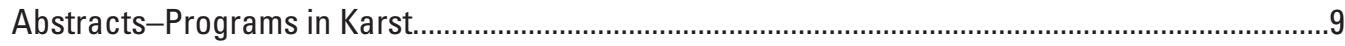

Promoting Diversity in the Geosciences Through University—Government

Partnerships and Karst Research ...........................................................................9

Next Generation Water Observing System Monitoring in the Little Lehigh Karst

Basin, Pennsylvania ................................................................................................

History and Future Directions of Karst in StreamStats ..........................................................16

Waters of the United States (WOTUS) Revisions Imperil Streams and Source

Waters for Vulnerable Karst Aquifers......................................................................17

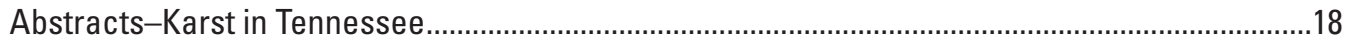

A Summary of Karst Regions in Tennessee ………………………....................................18

A Structural Explanation for the Relatively Large Mapped Length of Snail Shell

Cave, Central Tennessee.................................................................................................31

Karst Hydrogeology at the Tennessee Valley Authority Gallatin Fossil Plant and Impacts on the Fate and Transport of Coal Combustion Residuals ..............................32

Karst Hydrology of the Western Great Smoky Mountains ......................................................33

Abstracts-Agriculture and Karst Issues ...............................................................................

Communicating Karst Science-Lessons Learned From Hydrogeologic

Characterization of a Mantled Karst Near a Concentrated Animal Feeding

Operation in the Southern Ozarks, Northern Arkansas ..............................................34

Stimulation of Plant Growth by Karst Groundwater Naturally Rich in Sulfide

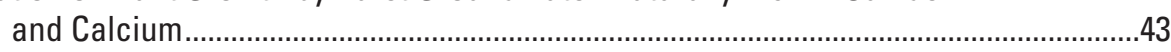

Abstracts-Contaminant Transport in Karst ............................................................................. 44

Identifying the Intersection of Contaminated Karst Water Sources and

Plain Communities in South-Central Kentucky Using a Geographic

Information System .............................................................................................4

Vulnerability of Karst Groundwater to Contamination From Emerging Contaminants............45

Groundwater Residence Time and Vulnerability in Carbonate Principal Aquifers

Across the United States ........................................................................................

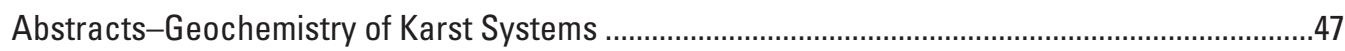

A Reactive Transport Framework for Understanding Geochemical Transformations

in Cave and Karst Systems ....................................................................................4

Using Initial Uranium Isotope Ratios in Speleothems as Paleoenvironmental Indicators .....48

A Quantitative Record of Rainfall Using Speleothem Calcium and Strontium Isotopes.........49

Geochemical Characterization and Comparison of Karst and Mineral Springs of Southwest Central Indiana ...........................................................................................51

Comparing Land Use and Groundwater Chemistry Across Karst Basins in the Mitchell Plateau of South-Central Indiana ................................................................52

Source Water Investigation of the Fort Stanton-Snowy River Cave System, New Mexico 
Stable Isotope and Geochemical Characterization of Nutrient Sources and Surface Water Near a Confined Animal Feeding Operation in the Big Creek

Watershed of Northwest Arkansas.

Preliminary Analysis of Hydrologic and Geochemical Data to Guide Groundwater-Flow Model Development for Two Karst Aquifers in Colorado .............64

Refining Methods to Estimate the Atmospheric Carbon Sink by Carbonate Dissolution ........76

Abstracts-Tracers in Karst . .77

Using Groundwater Fauna as Biological Tracers to Determine Hydrogeological Parameters in Karst Aquifers. . .77

Recharge Area Delineation for Manitou Cave, DeKalb County, Alabama ..............................82

Abstracts-Karst Hazards . .83

Methodology for a Preliminary Karst Depression Density Map of the Conterminous United States.

Salt Dissolution Tectonism and Spatiotemporal Aspects of Juxtaposed Sinkholes and Pseudo-Sinkholes of the Foreland Alberta Basin, Canada ...................................86

Abstracts-Geologic Framework of Karst Systems.

Geologic Framework and Hydrostratigraphy of the Edwards and Trinity Aquifers Within Hays County, Texas.

Lithologic and Tectonic Controls on the Hydrogeology of the Boone Formation in the Southern Ozarks, Northern Arkansas.

Hypogenic Origin of Paleokarst Caves in the Lower-Middle Ordovician in the Southern Tahe Oilfield, Tarim Basin, Northwest China.. .108

Abstracts-Geophysical Methods in Karst.. .109

Preferential Groundwater Flow in Karst Terrane Inferred From Geoelectric Measurements. 109

Cave Overburden Measurements Using Muons .110

Using Deep Resistivity Imaging to Target Fault Structures for Water Supply, Arbuckle-Simpson Aquifer, Oklahoma. 113

Abstracts-Karst Geomicrobiology.. .114

Harmful Algal Blooms in Karst Terrains. 114

Lampenflora Pigment and Microcystin Toxin in Mammoth Cave National Park, Kentucky 115

Insights Into the Microbial Diversity of the Karstic Upper Floridan Aquifer . .116

Influence of the Cumberland River on Groundwater Flow Direction in a Fuel-Contaminated Aquifer in Nashville, Tennessee 118

Abstracts-Karst Aquifer Systems 119

Karst Springs of Northern Arkansas .........................................................................119

Evaluation of Bubbling Springs in the Arbuckle Formation, Southern Oklahoma.................120

Abstracts-Simulation of Karst Aquifers .121

Recalibration at Sinking Pond, Tennessee-Implications of Climate Extremes for Understanding Hydrologic Controls on Karst Ecosystems

Simulating Groundwater Flow in Karst Aquifers With Distributed Parameter Models-A Comparison of Porous-Equivalent Media and Hybrid Flow Approaches.

Karst Interest Group Field Trip Guide to the Cumberland Plateau of Tennessee... .126 


\title{
U.S. Geological Survey Karst Interest Group Proceedings, October 19-20, 2021
}

\author{
Edited by Eve L. Kuniansky and Lawrence E. Spangler
}

\section{Introduction and Acknowledgments}

Karst hydrogeologic systems represent challenging and unique conditions to scientists attempting to study groundwater flow and contaminant transport. The distinctive hydrology and terrains that form from the dissolution and erosional processes of carbonate rocks (primarily limestone and dolomite) and evaporites (gypsum, anhydrite, and halite) define karst aquifer systems that are present throughout the world. Karst aquifer systems are complex; they result from past depositional environments, post-depositional tectonic events, and diagenetic and weathering processes. These factors involve biological, chemical, and physical changes that, when combined with the diverse climatic regimes in which karst development can occur, result in the unique dual- or triple-porosity nature of karst aquifers.

Karst terrains are characterized by distinct and beautiful landscapes, caverns, and springs, and many of the exceptional karst areas are designated as national or state parks. In addition, many privately owned caves in the United States have been developed commercially. Caves on both public and private properties can also provide access for scientists to study the flow of groundwater in situ. Likewise, the range and complexity of landforms and groundwater flow systems associated with karst terrains are enormous, perhaps more than any other aquifer type. Karst aquifers and landscapes that form in tropical areas, such as the cockpit karst along the north coast of Puerto Rico, differ greatly from karst landforms in more arid climates, such as the Edwards Plateau in west-central Texas or the Guadalupe Mountains near Carlsbad, New Mexico, where hypogenic processes have played a major role in speleogenesis. Caves, aquifers, and springs support a variety of unique flora and fauna, many of which are listed as federally endangered species. Understanding karst hydrology is vital for protecting these ecosystems, and as a result, numerous Federal, State, and local agencies have a strong interest in the study of karst terrains.

Most of the major springs and aquifers in the United States are developed in carbonate rocks associated with karst, such as the Floridan aquifer system in Florida and parts of Alabama, Georgia, and South Carolina; the Ozark Plateaus aquifer system in parts of Arkansas, Kansas, Missouri, and Oklahoma; and the Edwards-Trinity aquifer system in west-central Texas. These aquifers, and the springs that discharge from them, serve as major water-supply sources. Competition for the water resources of karst aquifers is common, and urban development and the lack of attenuation of contaminants in karst areas due to dissolution features that form direct pathways into karst aquifers can affect the ecosystem and water quality associated with these aquifers.

The concept for developing a platform for interaction among scientists within the U.S. Geological Survey (USGS) working on karst-related studies began at the November 1999 National Groundwater Meeting of the USGS. The resulting Karst Interest Group (KIG), formed in 2000, is a loosely knit, grassroots organization of USGS and non-USGS scientists and researchers devoted to fostering better communication among scientists working on, or interested in, karst science. The primary mission of the KIG is to encourage and support interdisciplinary collaboration and technology transfer among scientists working in karst areas. The KIG encourages collaborative studies between the different mission areas of the USGS, as well as with other Federal and State agencies and researchers from academia and institutes. To accomplish its mission, the KIG has organized a series of workshops that have been held near nationally important karst areas. To date (2021), eight KIG workshops, including the workshop documented in this report, have been held. The workshops have included oral and poster sessions on selected karst-related topics and research, as well as field trips to local karst areas. To increase non-USGS participation, an effort was made for the workshops to be held at a university or institute beginning with the fourth workshop. Proceedings of the workshops are published by the USGS and are available online at the USGS Publications Warehouse (https://pubs.er.usgs.gov/) by using the search term "karst interest group." 
The first KIG workshop was held in St. Petersburg, Florida, in 2001, near the large springs and other karst features of the Floridan aquifer system. The second KIG workshop was held in 2002, in Shepherdstown, West Virginia, in proximity to the carbonate aquifers of the northern Shenandoah Valley, and was highlighted by an invited presentation on karst literature by the late Barry F. Beck of P.E. LaMoreaux and Associates. The third KIG workshop was held in 2005, in Rapid City, South Dakota, near evaporite karst features in limestones of the Madison Group in the Black Hills of South Dakota. The Rapid City KIG workshop included field trips to Wind Cave National Park and Jewel Cave National Monument and featured a presentation by Thomas Casadevall, then USGS Central Region Director, on the status of Earth science at the USGS. The fourth KIG workshop in 2008 was hosted by the Hoffman Environmental Research Institute and Center for Cave and Karst Studies at Western Kentucky University in Bowling Green, Kentucky, near Mammoth Cave National Park and karst features of the Chester Upland and Pennyroyal Plateau. The workshop featured a late-night field trip into Mammoth Cave led by Rickard Toomey and Rick Olsen of the National Park Service.

The fifth KIG workshop in 2011 was a joint meeting of the USGS KIG and University of Arkansas HydroDays, hosted by the Department of Geosciences at the University of Arkansas in Fayetteville. The workshop featured a field trip to the unique karst terrain along the Buffalo National River in the southern Ozarks, and a keynote presentation on paleokarst in the United States was given by Art and Peggy Palmer. The sixth KIG workshop was hosted by the National Cave and Karst Research Institute (NCKRI) in 2014, in Carlsbad, New Mexico. George Veni, Director of the NCKRI, served as a co-chair of the workshop with Eve L. Kuniansky of the USGS. The workshop featured speaker Dr. Penelope Boston, Director of Cave and Karst Studies at New Mexico Tech, Socorro, and Academic Director at the NCKRI, who addressed the future of karst research. The field trip on evaporite karst of the lower Pecos Valley was led by Lewis Land (NCKRI karst hydrologist), and the field trip on the geology of Carlsbad Caverns National Park was led by George Veni, Director of the National Cave and Karst Research Institute. The seventh KIG workshop was held in San Antonio at the University of Texas at San Antonio (UTSA) in 2017. The workshop was hosted by the Department of Geological Sciences Student Geological Society (SGS), and student chapters of the American Association of Petroleum Geologists (AAPG) and Association of Engineering Geologists (AEG), with support by the UTSA Department of Geological Sciences and Center for Water Research. Two organizations assisted the UTSA student chapters in hosting the meeting by donating funds to the chapters: the Edwards Aquifer Authority (EAA), San Antonio, Texas, and the Barton Springs Edwards Aquifer Authority, Austin, Texas. Additionally, the UTSA Center for Water Research and Department of Geological Sciences helped develop sessions on cave and karst research in China for the workshop. The keynote speakers were George Veni (NCKRI) and Geary M. Schindel (EAA). The coordinators for the 2017 KIG workshop were Eve L. Kuniansky and Allan K. Clark of the USGS and Amy R. Clark and Alexis Godet from UTSA. The field trip, coordinated by Allan K. Clark and Amy R. Clark, highlighted current karst research occurring within the Edwards and Trinity karst systems and ended with viewing the bat flight out of Bracken Cave, where an estimated 15 to 20 million Mexican free-tailed bats roost during the summer months.

The spring 2020 KIG workshop was postponed and originally planned to be held in Nashville, Tennessee, and hosted by Tennessee State University (TSU). The decision was made to do a virtual workshop on October 19-20, 2021, and publish the abstracts already approved for the original in-person workshop. The planning committee for the eighth workshop includes Eve L. Kuniansky (USGS, Emeritus), Lawrence E. Spangler (USGS, Emeritus), Allan K. Clark (USGS), Douglas J. Schnoebelen (USGS), Thomas D. Byl (USGS and TSU), and Benjamin V. Miller (USGS). The co-coordinators for the event are Allan K. Clark and Douglas J. Schnoebelen. The workshop proceedings are edited by Eve L. Kuniansky and Lawrence E. Spangler. The field trip guide to the Cumberland Plateau of Tennessee is produced by Benjamin V. Miller and Brian Ham and included in the proceedings even though the field trip will not occur. Instead, a virtual field trip is available online (https://www.arcgis.com/apps/Cascade/index.html?appid=b6b200c50d1f425fa05f6ca44533ea59). The planning committee for the KIG would like to thank Ramona Neafie (USGS) for her hard work updating the KIG website and Lynne Fahlquist (USGS) for her assistance in obtaining meeting approval and assisting with the virtual workshop planning.

The extended abstracts of USGS authors were peer reviewed and approved for publication by the USGS. All articles had a minimum of two peer reviews and were edited for consistency of appearance in the proceedings. Articles submitted by university researchers and other Federal and State agencies may not have gone through the formal USGS peer review and approval process. The use of trade, firm, or product names is for descriptive purposes only and does not imply endorsement by the U.S. Government. The USGS Water Availability and Use Science Program funded the publication costs of the proceedings.

The organizers sincerely hope that this workshop continues to promote future collaboration among scientists of varied and diverse backgrounds and improves our understanding of karst aquifer systems in the United States and its territories.

Sincerely,

Allan K. Clark, Eve L. Kuniansky, and Douglas J. Schnoebelen

USGS Karst Interest Group Coordinators 


\section{Virtual Agenda for Online Participation, U.S. Geological Survey Karst Interest Group Workshop, October 19-20, 2021}

Fifteen-minute video presentations were produced for the virtual workshop, regardless of original oral or poster format, as no virtual poster session was conducted. Some of these presenters did not prepare an abstract for this proceedings, and no abstract is required for participation.

\begin{tabular}{|c|c|c|}
\hline \multicolumn{3}{|c|}{ Tuesday October 19, 2021} \\
\hline $\begin{array}{c}\text { Date and Time (Eastern } \\
\text { Daylight) }\end{array}$ & Authors *Corresponding Author & Title \\
\hline 10/19/2021 9:05 & D'Etra Young, Rick Toomey, and *Thomas Byl & $\begin{array}{l}\text { Promoting diversity in the geosciences through University- } \\
\text { Government partnerships and karst research }\end{array}$ \\
\hline 10/19/2021 9:20 & $\begin{array}{c}\text { *Melinda Chapman, Brandon Fleming, } \\
\text { Marla Stuckey, and Mark Beaver }\end{array}$ & $\begin{array}{l}\text { Next Generation Water Observing System monitoring in the } \\
\text { Little Lehigh karst basin in Pennsylvania }\end{array}$ \\
\hline $10 / 19 / 20219: 35$ & John W. Clune & $\begin{array}{l}\text { Small scale water-quality monitoring to inform } \\
\text { conservation management, Fishing Creek, Clinton } \\
\text { County, Pennsylvania }\end{array}$ \\
\hline 10/19/2021 9:50 & Question and Answer live & \\
\hline 10/19/2021 10:05 & break 10 minutes & \\
\hline $10 / 19 / 202110: 30$ & $\begin{array}{l}\text { *Tom Byl, Ben Miller, Rick Toomey, and } \\
\text { De'Etra Young }\end{array}$ & Harmful algal blooms in karst terrains \\
\hline $10 / 19 / 202110: 45$ & $\begin{array}{l}\text { *Adrian Barry-Sosa, Madison Flint, } \\
\text { Andrew Oberhelman, Justin Ellena, } \\
\text { Jonathan Martin, and Brent Christner }\end{array}$ & $\begin{array}{l}\text { Insights into the microbial diversity of the karstic Upper } \\
\text { Floridan Aquifer (UFA) }\end{array}$ \\
\hline 10/19/2021 11:00 & Question and Answer live & \\
\hline $10 / 19 / 202111: 15$ & break 10 minutes & \\
\hline $10 / 19 / 202111: 25$ & Daniel Doctor & $\begin{array}{l}\text { Methodology for a preliminary karst depression density } \\
\text { map of the conterminous United States }\end{array}$ \\
\hline $10 / 19 / 202111: 40$ & Paul Broughton & $\begin{array}{l}\text { Salt dissolution tectonism and spatiotemporal aspects } \\
\text { of juxtaposed sinkholes and pseudo-sinkholes of the } \\
\text { foreland Alberta Basin, Canada }\end{array}$ \\
\hline $10 / 19 / 202113: 00$ & Ben Miller & $\begin{array}{l}\text { Recharge area delineation for Manitou Cave, DeKalb } \\
\text { County, Alabama }\end{array}$ \\
\hline $10 / 19 / 202113: 15$ & $\begin{array}{l}\text { *Kevin Blackwood, Laramie Edens, } \\
\text { Michelle Allen, Jessica West, and } \\
\text { Cara Jackson }\end{array}$ & $\begin{array}{l}\text { Using groundwater fauna as biological tracers to determine } \\
\text { hydrogeological parameters in karst aquifers }\end{array}$ \\
\hline $10 / 19 / 202113: 30$ & Larry Spangler & $\begin{array}{l}\text { Selected results of an investigation of the Ashley Spring } \\
\text { flow system in the Uinta Mountains, Utah }\end{array}$ \\
\hline $10 / 19 / 202113: 45$ & Question and Answer live & \\
\hline
\end{tabular}




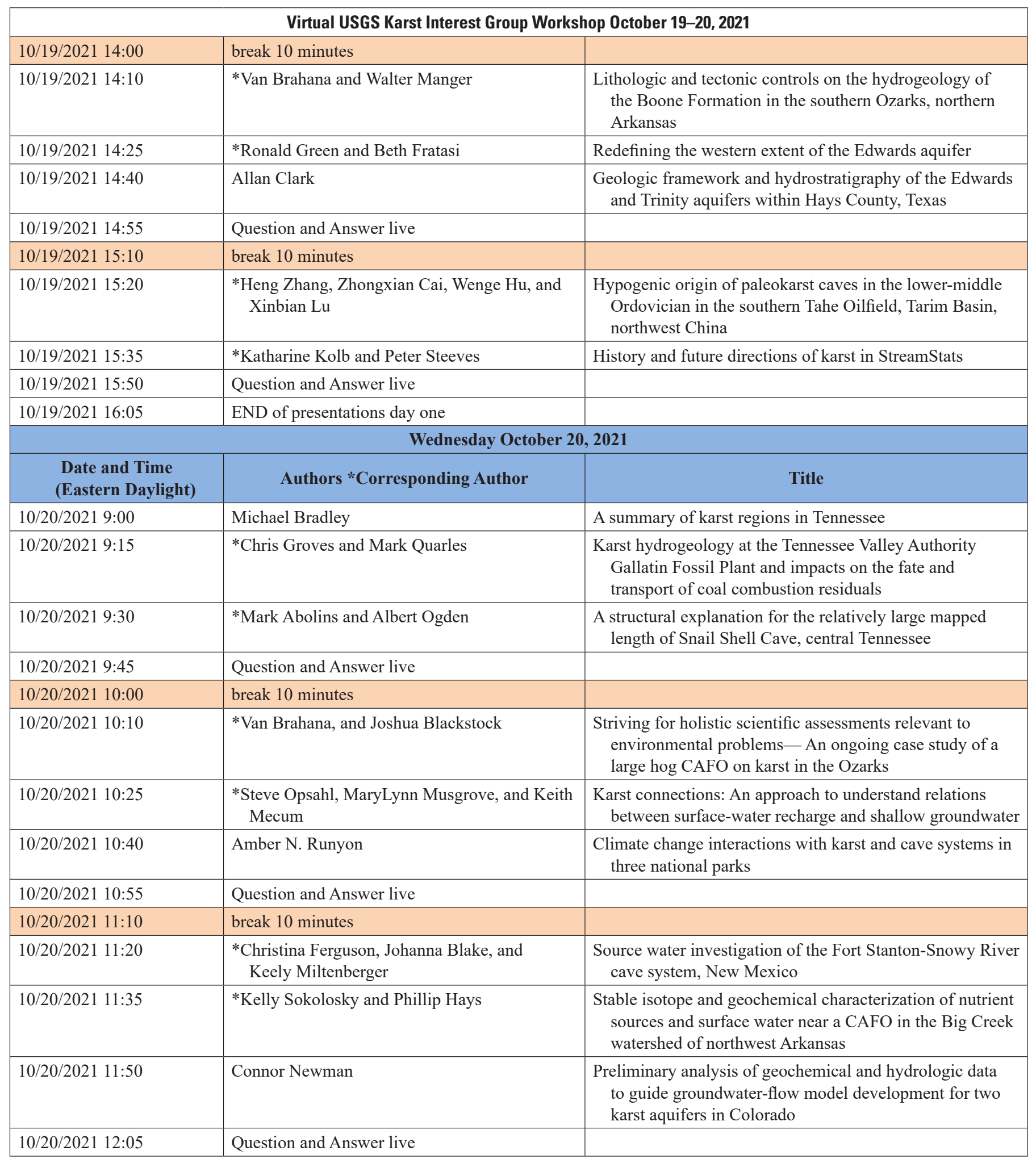




\begin{tabular}{|c|c|c|}
\hline \multicolumn{3}{|c|}{ Virtual USGS Karst Interest Group Workshop October 19-20, 2021} \\
\hline $10 / 20 / 202112: 20$ & lunch break 40 minutes & \\
\hline 10/20/2021 13:00 & $\begin{array}{l}\text { *Autumn Singer, Chris Groves, Jun Yan, } \\
\text { Michael May, and Albert Meier }\end{array}$ & $\begin{array}{l}\text { Refining methods to estimate the atmospheric carbon sink } \\
\text { by carbonate dissolution }\end{array}$ \\
\hline $10 / 20 / 202113: 15$ & *Jessica Oster and Jennifer Druhan & $\begin{array}{l}\text { A reactive transport framework for understanding } \\
\text { geochemical transformations in cave and karst systems }\end{array}$ \\
\hline $10 / 20 / 202113: 30$ & *Scott Ikard and Emily Pease & $\begin{array}{l}\text { Preferential groundwater flow in karst terrane inferred from } \\
\text { geoelectric measurements }\end{array}$ \\
\hline $10 / 20 / 202113: 45$ & Question and Answer live & \\
\hline $10 / 20 / 202114: 00$ & break 10 minutes & \\
\hline $10 / 20 / 202114: 10$ & *Ben Miller and Michael Bradley & Karst hydrology of the western Great Smoky Mountains \\
\hline $10 / 20 / 202114: 25$ & *Todd Halihan and Robert Agnew & $\begin{array}{l}\text { Evaluation of bubbling springs in the Arbuckle Formation, } \\
\text { southern Oklahoma }\end{array}$ \\
\hline $10 / 20 / 202115: 10$ & Question and Answer live & \\
\hline $10 / 20 / 202115: 30$ & Open discussion 1 hour & $\begin{array}{l}\text { Monitoring karst and cave system response to climate } \\
\text { change-What to measure and analyze to assist resource } \\
\text { managers }\end{array}$ \\
\hline $10 / 20 / 202116: 30$ & END & \\
\hline
\end{tabular}




\section{Original Agenda for U.S. Geological Survey Karst Interest Group Workshop, Nashville, Tennessee, May 13-15, 2020}

This is the original agenda for the in-person workshop and is provided owing to all the abstracts included in the proceedings were approved for the original workshop. Many of the students that co-authored abstracts graduated and were unavailable for the virtual-only workshop as were many of the original speakers and poster presenters.

\begin{tabular}{|c|c|c|c|}
\hline \multicolumn{4}{|c|}{ DAY 1 TECHNICAL SESSION } \\
\hline \multicolumn{4}{|c|}{ Tuesday May 13, 2020} \\
\hline \multirow[t]{2}{*}{$7: 45$} & Registration & $\begin{array}{l}\text { You may pick up name tags and purchase lunch for the field trip } \\
\text { until } 4 \text { p.m. }\end{array}$ & \\
\hline & Session 1 & $\begin{array}{l}\text { Allan Clark, USGS Oklahoma-Texas Water Science Center and } \\
\text { Karst Interest Group Coordinator }\end{array}$ & Moderator \\
\hline $8: 00$ & $\begin{array}{l}\text { TSU Dean of Agriculture, Dr. Chandra Reddy } \\
\text { and USGS Lower-Mississippi-Gulf Center } \\
\text { Director, Rodney Knight }\end{array}$ & $\begin{array}{l}\text { Welcome to the 8th USGS Karst Interest Group Workshop from } \\
\text { our hosts TSU and USGS LMG Water Science Center }\end{array}$ & \\
\hline $8: 30$ & $\begin{array}{l}\text { D'Etra Young, Rickard Toomey, III, and } \\
\text { Thomas Byl }\end{array}$ & $\begin{array}{l}\text { Promoting Diversity in the Geosciences Through University - } \\
\text { Government Partnerships and Karst Research }\end{array}$ & Day 1 Keynote \\
\hline 9:00 & Ron Green and Beth Beth Fratesi & Redefining the Western Extent of the Edwards Aquifer & \\
\hline $9: 20$ & J. Ryan Banta & $\begin{array}{c}\text { Estimating Groundwater-Recharge Rates in a Multi-Aquifer } \\
\text { Karst Environment. A Case Study of Medina Lake, Texas }\end{array}$ & \\
\hline $10: 00$ & & BREAK & \\
\hline $10: 40$ & Daniel Doctor & $\begin{array}{l}\text { Methodology for a Preliminary Karst Depression Density Map } \\
\text { of the Conterminous United States }\end{array}$ & \\
\hline $11: 00$ & Paul Broughton & $\begin{array}{l}\text { Salt Dissolution Tectonism and Spatiotemporal Aspects of } \\
\text { Juxtaposed Sinkholes and Pseudo-Sinkholes of the Foreland } \\
\text { Alberta Basin, Canada }\end{array}$ & \\
\hline $11: 20$ & J. Van Brahana and Walter Manger & $\begin{array}{l}\text { Lithologic and Tectonic Controls on the Hydrogeology of the } \\
\text { Boone Formation in the Southern Ozarks }\end{array}$ & \\
\hline \multirow[t]{2}{*}{$11: 40$} & & LUNCH ON YOUR OWN & \\
\hline & Session 2 & $\begin{array}{l}\text { Doug Schnoebelen, USGS, Branch Chief, South Texas and Karst } \\
\text { Interest Group co-coordinator }\end{array}$ & Moderator \\
\hline $14: 05$ & $\begin{array}{l}\text { Steve Opsahl, MaryLynn Musgrove, and } \\
\text { Keith Mecum }\end{array}$ & $\begin{array}{l}\text { Urban Recharge: An Approach to Understand the Water-Quality } \\
\text { Connection Between Surface-Water Recharge and Unconfined } \\
\text { Groundwater in Karst }\end{array}$ & \\
\hline $14: 25$ & $\begin{array}{l}\text { MaryLynn Musgrove, Bryant C. Jurgens, } \\
\text { Mitchell A. McAdoo, and } \\
\text { Kirsten E. Faulkner }\end{array}$ & $\begin{array}{l}\text { Groundwater Residence Time and Vulnerability in Carbonate } \\
\text { Principal Aquifers Across the United States of America }\end{array}$ & \\
\hline $14: 45$ & & BREAK & \\
\hline $15: 00$ & Larry Spangler & $\begin{array}{l}\text { Selected Results of an Investigation of the Ashley Spring Flow } \\
\text { System in the Uinta Mountains, Utah }\end{array}$ & \\
\hline
\end{tabular}




\begin{tabular}{|c|c|c|c|}
\hline $15: 20$ & Scott Ikard and Emily Pease & $\begin{array}{l}\text { Preferential Groundwater Seepage in Karst Terrain Inferred from } \\
\text { Geoelectric Measurements }\end{array}$ & \\
\hline $15: 40$ & Andrew Teeple & Geophysical Capabilities in Karst Environments & \\
\hline \multicolumn{4}{|c|}{ DAY 2 TECHNICAL SESSION } \\
\hline \multicolumn{4}{|c|}{ Wednesday May 14, 2020} \\
\hline 8:00 & Michael Bradley & A Summary of Karst Regions in Tennessee & Day 2 Keynote \\
\hline $8: 30$ & Van Brahana and John Svendsen & Karst Springs of Northern Arkansas & \\
\hline $8: 50$ & Todd Halihan and Robert Agnew & $\begin{array}{l}\text { Evaluation of Bubbling Springs in the Arbuckle Formation, } \\
\text { Southern Oklahoma }\end{array}$ & \\
\hline 9:50 & & BREAK & \\
\hline $10: 20$ & $\begin{array}{l}\text { Christina Ferguson, Johanna Blake, } \\
\text { Keely Miltenberger }\end{array}$ & $\begin{array}{l}\text { Fort Stanton-Snowy River Cave System Source Water } \\
\text { Investigation }\end{array}$ & \\
\hline $10: 40$ & Kelly Sokolosky and Phillip Hays & $\begin{array}{l}\text { Stable Isotope and Geochemical Characterization of Nutrient } \\
\text { Sources in the Karst of Big Creek Watershed in Northwest } \\
\text { Arkansas }\end{array}$ & \\
\hline $11: 00$ & Jessica L. Oster and Jennifer L. Druhan & $\begin{array}{l}\text { A Reactive Transport Framework for Understanding } \\
\text { Geochemical Transformations in Cave and Karst Terrain }\end{array}$ & \\
\hline $11: 20$ & Connor Newman & $\begin{array}{l}\text { Preliminary Analysis of Hydrologic and Geochemical Data to } \\
\text { Guide Groundwater-Flow Model Development in Two Karst } \\
\text { Aquifers in Colorado }\end{array}$ & \\
\hline $13: 20$ & Mark Abolins and Albert Ogden (emeritus) & $\begin{array}{l}\text { A Structural Explanation for the Relatively Large Mapped } \\
\text { Length of Snail Shell Cave, Central Tennessee }\end{array}$ & \\
\hline $13: 40$ & Jennifer Cartwright and William Wolfe & $\begin{array}{l}\text { Recalibration at Sinking Pond: Implications of Climate } \\
\text { Extremes for Understanding Hydrologic Controls on Karst } \\
\text { Ecosystems }\end{array}$ & \\
\hline $14: 00$ & $\begin{array}{l}\text { Tom Byl, Ben Miller, Rick Toomey, } \\
\text { De'Etra Young }\end{array}$ & Harmful Algal Blooms in Karst Terrains & \\
\hline $14: 20$ & & BREAK & \\
\hline $15: 00$ & Chris Groves and Mark Quarles & $\begin{array}{l}\text { Karst Hydrogeology at Tennessee's TVA Gallatin Fossil Plant } \\
\text { and Impacts on the Fate and Transport of Coal Combustion } \\
\text { Residuals }\end{array}$ & \\
\hline $15: 20$ & Andrew Teeple & Geophysical Results from the Demonstration & \\
\hline $15: 40$ & Ben Miller & Karst Hydrology of the Western Great Smoky Mountains & \\
\hline \multirow[t]{2}{*}{$16: 00$} & Ben Miller/Allan Clark & Field Trip Logistics/ KIG Business-where to do next workshop & \\
\hline & & Adjourn & \\
\hline \multicolumn{4}{|c|}{ DAY 3 OPTIONAL FIELD TRIP } \\
\hline $8: 00$ & & Thursday May 15, 2020 all day & \\
\hline
\end{tabular}




\begin{tabular}{|c|c|c|}
\hline & POSTER PRESENTERS & $\begin{array}{l}\text { POSTER SESSION IS TUESDAY EVENING AFTER TECHNICAL SESSION } \\
4 \text { to } 6 \text { p.m. }\end{array}$ \\
\hline 1 & Danelle Solomon, De'Etra Young, and Tom Byl & $\begin{array}{l}\text { Stimulation of Plant Growth by Karst Groundwater Naturally Rich in } \\
\text { Sulfide and Calcium }\end{array}$ \\
\hline 2 & $\begin{array}{l}\text { Heng Zhang, Zhongxian Cai, Wenge Hu, and } \\
\text { Xinbian Lu }\end{array}$ & $\begin{array}{l}\text { Hypogenic Origin of Paleokarst Caves in the Lower-Middle Ordovician in } \\
\text { the Southern Tahe Oilfield, Tarim Basin, China }\end{array}$ \\
\hline 3 & Yunxia Li & $\begin{array}{l}\text { The Consistency and Inconsistency Between the Stalagmite } \delta 13 \mathrm{C} \text { and } \\
\delta 18 \mathrm{O} \text { Records Over the Past } 130 \mathrm{ka} \text { from Zhenzhu Cave in North China }\end{array}$ \\
\hline 4 & Allan Clark & $\begin{array}{l}\text { Geologic Framework and Hydrostratigraphy of the Edwards and Trinity } \\
\text { Aquifers Within Medina County, Texas }\end{array}$ \\
\hline 5 & Todd Halihan and Madison Culver & $\begin{array}{l}\text { Using Deep Resistivity Imaging to Target Fault Structures for Water } \\
\text { Supply, Arbuckle-Simpson Aquifer, Oklahoma }\end{array}$ \\
\hline 6 & Sid Jones, Gareth Davies, John Hoffelt, and Terri Brown & $\begin{array}{l}\text { Waters of the United States (WOTUS) Revisions Imperil Streams and } \\
\text { Source Waters Especially for Vulnerable Karst Aquifers }\end{array}$ \\
\hline 9 & John W. Clune & $\begin{array}{l}\text { Small Scale Water-Quality Monitoring to Inform Conservation } \\
\text { Management, Fishing Creek, Clinton County, Pennsylvania }\end{array}$ \\
\hline 10 & Katharine Kolb and Peter A. Steeves & History and Future Directions of Karst in StreamStats \\
\hline 11 & Ben Miller & Recharge Area Delineation for Manitou Cave, DeKalb County, Alabama \\
\hline 12 & $\begin{array}{l}\text { Elli Ronay, Warren Sharp, David Furbish, } \\
\text { Sebastian F. M. Breitenbach, and Jessica Oster }\end{array}$ & $\begin{array}{l}\text { Using Initial Uranium Isotope Ratios in Speleothems as } \\
\text { Paleoenvironmental Indicators }\end{array}$ \\
\hline 13 & $\begin{array}{l}\text { Cameron B. de Wet, Andrea M. Erhardt, } \\
\text { Naomi E. Marks, Warren D. Sharp, Yiruo Xu, and } \\
\text { Jessica L. Oster }\end{array}$ & $\begin{array}{l}\text { A Quantitative Record of Rainfall Using Speleothem Calcium and } \\
\text { Strontium Isotopes }\end{array}$ \\
\hline 17 & Lee Anne Bledsoe, Chris Groves, and Rick Toomey & $\begin{array}{l}\text { High-Resolution, Three-Dimensional Groundwater Flow Mapping in the } \\
\text { Great Onyx Groundwater Basin, Mammoth Cave National Park }\end{array}$ \\
\hline 18 & $\begin{array}{l}\text { Amy Hourigan, Patricia N. Kambesis, Chris Groves, } \\
\text { Margaret Gripshover, Susan Jones, Lee Anne Bledsoe, } \\
\text { and Autumn Singer }\end{array}$ & $\begin{array}{l}\text { Identifying the Intersection of Contaminated Karst Water Sources and Plain } \\
\text { Communities in South-Central Kentucky Using GIS }\end{array}$ \\
\hline 19 & Barbara J. Mahler and MaryLynn Musgrove & $\begin{array}{l}\text { Vulnerability of Karst Groundwater to Contamination From Emerging } \\
\text { Contaminants }\end{array}$ \\
\hline 20 & $\begin{array}{l}\text { Autumn Singer, Chris Groves, Jun Yan, Michael May, } \\
\text { and Albert Meier }\end{array}$ & $\begin{array}{l}\text { Refining Methods to Estimate the Atmospheric Carbon Sink by Carbonate } \\
\text { Dissolution }\end{array}$ \\
\hline 21 & Eve Kuniansky & $\begin{array}{l}\text { Simulating Groundwater Flow in Karst Aquifers with Distributed } \\
\text { Parameter Models-A Comparison of Porous-Equivalent Media and } \\
\text { Hybrid Flow Approaches }\end{array}$ \\
\hline 22 & $\begin{array}{l}\text { Adrian Barry-Sosa, Madison K. Flint, } \\
\text { Andrew Oberhelman, Justin C. Ellena, } \\
\text { Jonathan B. Martin, and Brent C. Christner }\end{array}$ & $\begin{array}{l}\text { Insights Into the Microbial Diversity of the Karstic Upper Floridan Aquifer } \\
\text { (UFA) }\end{array}$ \\
\hline
\end{tabular}




\title{
Abstracts-Programs in Karst
}

\section{Promoting Diversity in the Geosciences Through University—Government Partnerships and Karst Research}

\author{
By De'Etra Young, ${ }^{1}$ Rickard Toomey, ${ }^{2}$ and Thomas By|1,3
}

\author{
${ }^{1}$ Tennessee State University, College of Agriculture and Environmental Science, 3500 John A Merritt Blvd, Nashville, TN 37209 \\ ${ }^{2}$ Mammoth Cave National Park, Division of Science and Resource Management, P.O. Box 7, Mammoth Cave, KY 42259. \\ ${ }^{3}$ U.S. Geological Survey, 640 Grassmere Park, Suite 100, Nashville, TN 37211. \\ (Email: tdbyl@usgs.gov)
}

\section{Abstract}

A workforce that draws from all segments of society and mirrors the ethnic, racial, and gender diversity of the United States population is important. The geosciences (geology, hydrology, geospatial sciences, environmental sciences) continue to lag far behind other science, technology, engineering, and mathematical (STEM) disciplines in recruiting and retaining minorities (Valasco and de Valasco, 2010). A report published by the National Science Foundation in 2019, "Women, Minorities, and Persons with Disabilities in Science and Engineering," states that from 2002 to 2018, less than 2 percent of the geoscience degrees were awarded to African-American students. Data also show that as of 2016, approximately 30 percent of African-American Doctor of Philosophy (Ph.D.) graduates obtained a bachelor's degree from Historically Black Colleges and Universities (HBCU), indicating that HBCUs are a great source of diverse students for the geosciences. This paper reviews how a research partnership between Tennessee State University (TSU), the U.S. Geological Survey (USGS), and Mammoth Cave National Park (MACA) engaged students in scientific research and increased the number of students pursuing employment or graduate degrees in the geosciences and was previously published in the Proceedings of the 11th Research Symposium at Mammoth Cave National Park (Young and others, 2016). Updates in this current version reflect changes in the partnership since Young and others (2016) was published. The student projects focused on water resources in a karst terrain and included a wide range of research topics including parking lot runoff and filter efficiency, groundwater recharge and chemical transport, quantitative tracer studies, karst hydrology model development, geophysical logging, emergency spill response, geochemistry, and geomicrobiology (Bradley and others, 2011; Painter and others, 2013; Byl and others, 2014; Solomon and others, 2014; Brown and others, 2017;
Hogan and others, 2019). These projects used a variety of tools and methods including field data collection, geographic information systems, chemical and biological analyses, hydrologic instrumentation, modeling, and experimentation.

Tennessee State University is a land-grant university in Nashville, Tennessee, offering 45 bachelor's degrees, 24 master's degrees, and 7 Ph.D. degrees. Although TSU does not offer a geoscience degree, it has several degrees that introduce concepts about the earth and environmental sciences, such as environmental engineering, agriculture and environmental sciences, biology, and chemistry. Thirty-four students (18 male, 16 female) participated in karst research projects from 2007 to 2020 . They represented majors in agriculture and environmental sciences, environmental engineering, and mathematical, chemical, and biological sciences. Each student interpreted data collected as part of their research and presented their results at a regional or national conference. Approximately half of the 34 students have graduated and found employment in the earth and environmental science field, whereas the other half are still pursuing academic degrees in related fields at this time.

When the students were asked what influenced them to pursue a career in the geoscience profession, the overwhelming response was their research experiences that allowed them to collaborate with earth and environmental scientists. The student's research experience showed them the importance of water resource and environmental studies in helping to solve real-world environmental problems. The research opportunities and professional meetings also provided an opportunity for the students to learn of employment opportunities, make professional connections, and feel like they could make a difference pursuing a career in the geosciences. Another benefit of the student research was the financial assistance, which reduced the need to work off campus. 
The benefits of experiential learning through

undergraduate research go far beyond developing research methods skills. The outcome for these 34 students supports the findings that structured research with faculty or professional geoscientists help students develop cognitive skills, strengthen personal and professional relationships, improve retention, and enhance graduate school aspirations (Palmer, 2009; Haak and others, 2011; Freeman and others, 2014). A series of STEM learning models developed by the National Research Council (2005) recognize several key components to successful student learning:

(1) Learning and doing are inseparable (Cantwell, 2004). For example, calculating storm runoff from a parking lot or discharge in a cave stream enabled students to "learn science by doing science" (fig. 1).

(2) Students learn in deep and enduring ways when they are actively engaged in authentic, real-world projectbased problem solving (King and others, 2006). For example, organizing and interpreting large datasets from in situ monitoring equipment provided a lasting impression through real-world applications (fig. 2).

(3) Inquiry-based educational materials (such as problembased learning modules and case studies) are effective in improving student learning, attitudes, and interests (Michaelsen and others, 1996). In this partnership, students applied methods from three previous studies (Mull and others, 1988; Field, 2002; Palmer, 2007) to conduct quantitative dye studies throughout MACA (fig. 3).

(4) The students were able to move beyond the classroom and experience the scientific method (theory, experimental design, instrumentation, measurement and data collection, data analysis, and presentation) in a realworld setting. This approach is a substantial pedagogical building block that stimulates and retains students and prepares them well for their professional careers (fig. 4).

(5) Students were encouraged to consider the issues that were posed by employees from the USGS and Mammoth Cave Learning Center, develop a study plan, work with their mentors to implement the plan, and present the results at an appropriate forum (fig. 5).

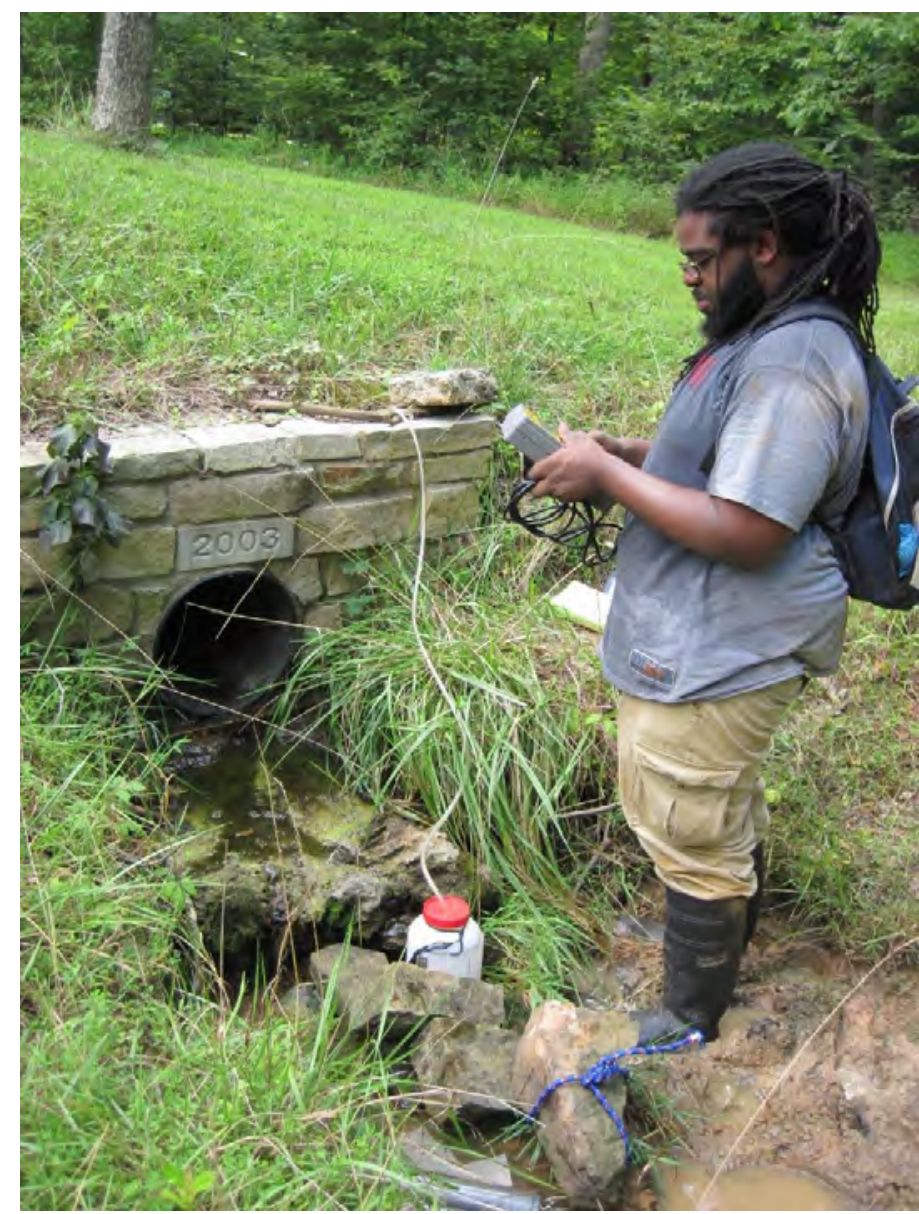

Figure 1. Tennessee State University student Victor Roland (currently a hydrologist at the U.S. Geological Survey) setting up a storm monitoring station at the Mammoth Cave National Park Post Office parking lot. Photo taken by Tom Byl, U.S. Geological Survey, 2012.

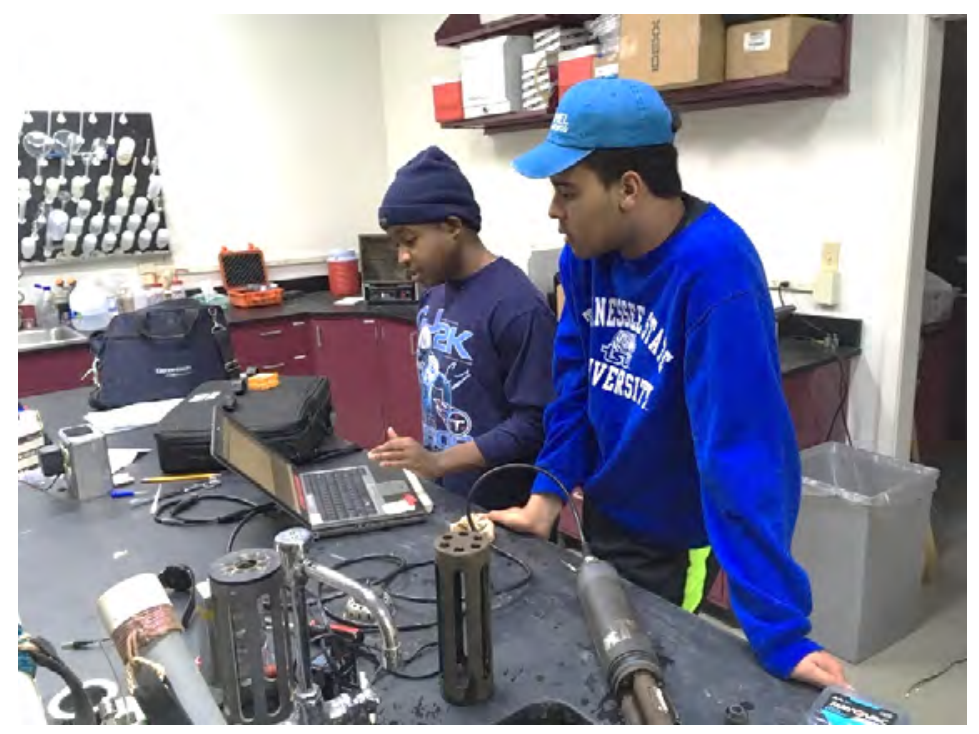

Figure 2. Undergraduate Tennessee State University students Jonathan Alford and Rodney Blackwell, Jr. uploading data, and servicing and calibrating sondes for water monitoring. Photo taken by Tom Byl, U.S. Geological Survey, 2018. 


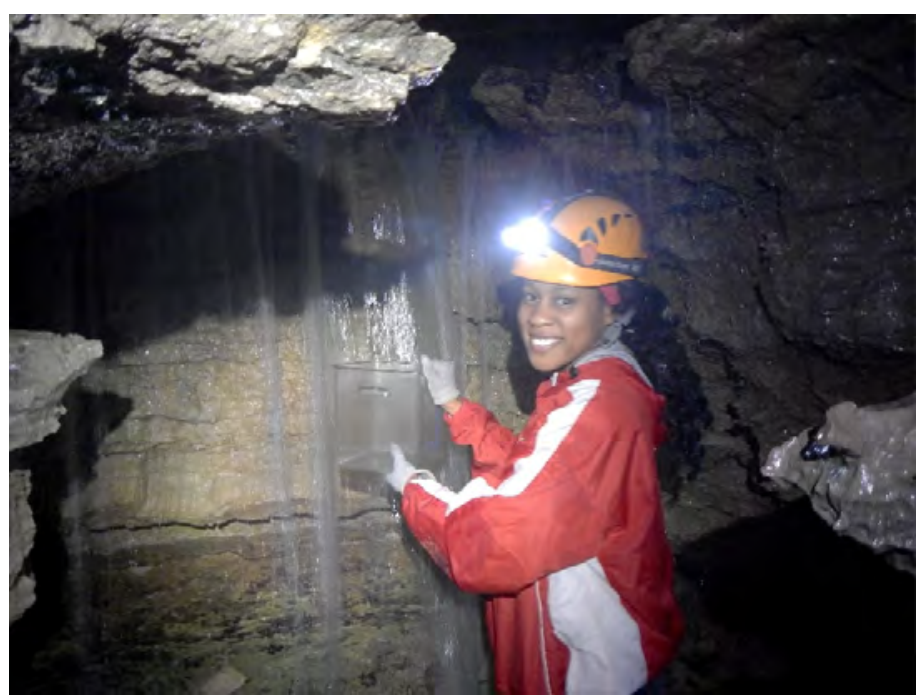

Figure 3. Tennessee State University student Je'Tara Brown collecting a background sample at Lee's Cistern in the Historic section of Mammoth Cave prior to initiating a dye tracer test. Photo taken by Tom Byl, U.S. Geological Survey, 2015.

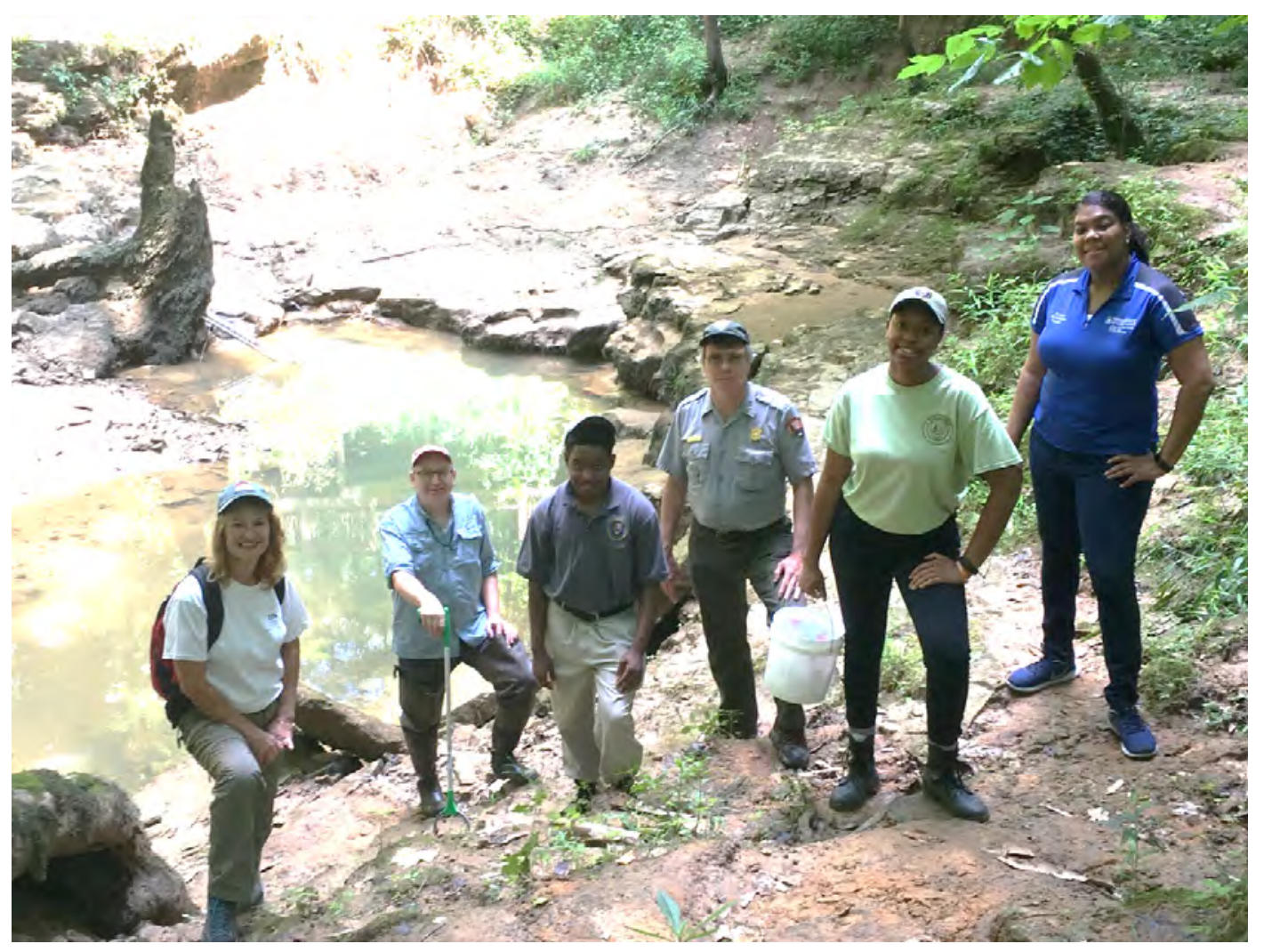

Figure 4. Elisa D’Angelo (University of Kentucky), Tom Byl (U.S. Geological Survey), Jonathan Alford (Tennessee State University [TSU]), Rick Toomey (Mammoth Cave National Park), Alexis Dingle (TSU), and De'Etra Young (TSU) at Echo Spring after placing passive samplers in the spring and collecting water samples. Photo taken by Ben Miller, U.S. Geological Survey, 2019. 


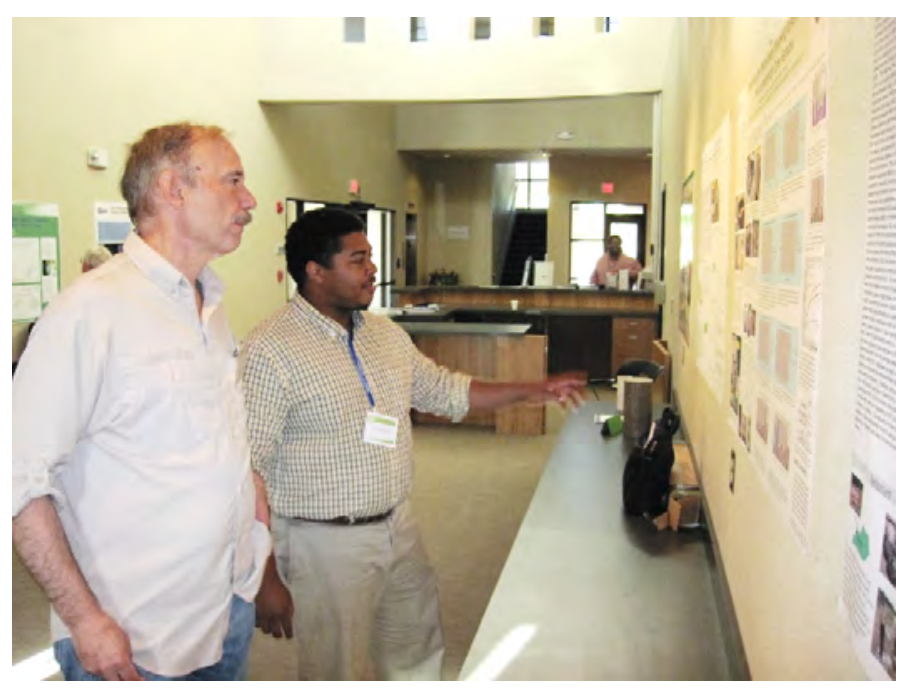

Figure 5. Ron Harvey (U.S. Geological Survey, emeritus) and David Solomon (Tennessee State University) discuss tracer studies in the poster session at the Karst Interest Group conference, Carlsbad, NM. Photo taken by Tom Byl, U.S. Geological Survey, 2014.

Our experiences support findings presented by Villarejo and others (2008) that undergraduate research experiences also play an important role in student career exploration and career choice. Lopatto (2007) conducted a survey of undergraduate research experiences and found that over 83 percent of the 1,135 students who participated in undergraduate research programs began or continued to plan for postgraduate education. Laursen and others (2010) describe in their book on undergraduate research in the sciences how students perceive their learning to be greater through research than through ordinary classes. Students reported increased technical skill, self-confidence, communication skills, and insight into advanced study and career possibilities. The improved self-esteem and competence also translated to improved student persistence and retention.

The informal partnership between TSU, the USGS, and MACA is helping to increase diversity in the geosciences through research experiences and professional development.
The success of this informal partnership laid the foundation for a formal partnership between TSU's environmental science and Vanderbilt University's geoscience programs, called Earth Horizons, and sponsored by the National Science Foundation. The USGS and MACA are a vital part of the Earth Horizons program by continuing to provide internships, seminar speakers, research, and professional development opportunities.

As energy, climate change, water resources, and other earth science issues become increasingly complex during the 21 st century, geoscientists will encounter more difficult problems. The future success of the geoscience community to help society understand and interact with the Earth system will depend on a diverse geoscience workforce that has insight into topics of concern for race, ethnicity, gender and cultural groups. Institutions must implement programs to increase minority participation in earth science disciplines, increasing the United States' cultural balance and global competitiveness in the coming decades. In the next 10 years, the jobs available to college graduates will demand STEM skills and knowledge. Recruiting and retaining students with strong academic achievements through real-world geoscience projects becomes the first step in producing college graduates with these necessary skills (Huntoon and Lane, 2007; Murray and others, 2012). A diverse geoscience workforce is essential to helping society understand and respond to increasingly complex geoscience issues, especially with regards to topics of concern for different racial, ethnic, and cultural groups.

\section{Acknowledgments}

The authors thank Tim Pinion, Shannon Trimboli, Rick Olson, Liz Thomas, Bobby Carson, Steve Kovar, Larry Johnson, Johnathan Jernigan, and Barclay Trimble of Mammoth Cave National Park; Michael Bradley, Eleanour Snow, and Ben Miller of the U.S. Geological Survey; Jessica Oster, Lily Claiborne, Neil Kelley, Chris Vanags, and Steve Goodbred of Vanderbilt University; and Chandra Reddy, Bill Sutton, Lonnie Sharpe, and Roger Painter of Tennessee State University for support and assistance with student research projects over the years. 


\section{References Cited}

Bradley, M.W., Armstrong, P., and Byl, T.D., eds., 2011, Partnership in environmental education and research-A compilation of student research, 1999-2008: U.S. Geological Survey Open-File Report 2010-1291, 67 p., http://pubs.usgs.gov/of/2010/1291/pdf/ofr20101291.pdf.

Brown, J.T., Byl, T.D., Toomey, R., III, and Sharpe, Jr., L., 2017, Quantitative dye studies to evaluate the spill response system for Mammoth Cave National Park, in White, W.B., and others, eds., Karst groundwater contamination and public health-Beyond case studies: Advances in Karst Sciences, Springer International, p. 91-95.

Byl, T.D., Metge, D.W., Agymang, D.T., Bradley, M., Hileman, G., and Harvey, R.W., 2014, Adaptations of indigenous bacteria to karst aquifers contaminated with fuel in south-central Kentucky: Journal of Cave and Karst Studies, v. 76, no. 2, p. 104-113, DOI: $10.4311 / 2012 \mathrm{MB} 0270$ [Also available at https://caves.org/pub/journal/PDF/v76/cave-76-02-104.pdf.]

Cantwell, L.B., 2004, A comparison of learningIntegration of a virtual and traditional field trip into an introductory environmental geology course: Boseman, Montana State University, Master's thesis, http://scholarworks.montana.edu/xmlui/bitstream/handle/1/ 1038/CantwellL1204.pdf?sequence=1\&isAllowed=y.

Field, M., 2002, The QTRACER2 program for tracer-breakthrough curve analysis for tracer tests in karstic aquifers and other hydrologic systems: Washington, D.C., National Center for Environmental Assessment, U.S. Environmental Protection Agency report EPA/600/R-02/001, 194 p.

Freeman, S., Eddy, S.L., McDonough, M., Smith, M.K., Okoroafor, N., Jordt, H., and Wenderoth, M.P., 2014, Active learning increases student performance in science, engineering, and mathematics: Proceedings of the National Academy of Sciences, v. 111, p. 8410-8415.

Haak, D.C., HilleRisLambers, J., Pitre, E., and Freeman, S., 2011, Increased structure and active learning reduce the achievement gap in introductory biology: Science, v. 332, p. 1213-1216.

Hogan, B., Toomey, R., Young, D., and Byl, T.D., 2019, The use of a fluorescence probe to characterize lampenflora in Mammoth Cave National Park [abs.]: Proceedings from the 28th Tennessee Water Resources Symposium, Montgomery Bell State Park, Burns, TN, April 10-12, 2019, P-21, https://tnawra.org/library.
Huntoon, J.E., and Lane, M.J., 2007, Diversity in the geosciences and successful strategies for increasing diversity: Journal of Geoscience Education, v. 55, p. 447-457.

King, L., Painter, R., and Byl, T., 2006, Research approach to teaching groundwater biodegradation in karst aquifers: American Society for Engineering Education 2006 Annual Conference and Exposition, Chicago, Illinois, June 18-21, 2006, Proceedings, 10.18260/1-2-953, https://peer.asee.org/953.

Laursen, S., Hunter, A.B., Seymour, E., Thiry, H., and Melton, G., 2010, Undergraduate research in the sciences-Engaging students in real science: San Fransisco, CA., Jossey-Bass, A., Wiley Imprint, 320 p., ISBN 978-0-470-22757-2.

Lopatto, D., 2007, Undergraduate research experiences support science career decisions and active learning: CBE-Life Sciences Education, American Society for Cell Biology, v. 6, p. 297-306.

Michaelsen, L.K., Fink, L.D., and Black, R.H., 1996, What every faculty developer needs to know about learning groups to improve the Academy: DigitalCommons@University of Nebraska-Lincoln, Paper 361, http://digitalcommons.unl.edu/ podimproveacad/361.

Mull, D.S., Liebermann, T.D., Smoot, J.L., and Woosley, Jr., L.H., 1988, Application of dye-tracing techniques for determining solute-transport characteristics of ground water in karst terranes: Atlanta, GA, U.S. Environmental Protection Agency, EPA904/6-88-001, 103 p.

Murray, K.S., Napieralski, J., Luera, G., Thomas-Brown, K., and Reynolds-Keefer, L., 2012, Broadening diversity in the geosciences through teacher-student workshops that emphasize community-based research projects: Journal of Geoscience Education, v. 60, p. 179-188.

National Research Council, 2005, How students learnScience in the classroom, Donovan, M.S., and Bransford, J.D., eds.: Washington, D.C., The National Academies Press, 264 p., https://doi.org/10.17226/11102.

National Science Foundation, 2019, Women, minorities, and persons with disabilities in science and engineering: Alexandria, VA, National Center for Science and Engineering Statistics, NSF19-304, https://ncses.nsf.gov/pubs/nsf19304/digest. 
Painter, R., Embry, I., Roland, V., Toomey, R., Sharpe, Jr., L., and Byl, T.D., 2013, An alternative to the advection dispersion model for interpreting dye tracing studies in fractured-rock and karst aquifers, in Trimboli, S.R., ed., Proceedings of Mammoth Cave National Park's 10th Research Symposium - Celebrating diversity of research in the Mammoth Cave region, Mammoth Cave, KY, February 14-15, 2013: Mammoth Cave Research Symposia, p. 99-102, https://digitalcommons.wku.edu/mc_reserch_ symp/10th_Research_Symposium_2013/.

Palmer, A.N., 2007, Cave geology: Dayton, Ohio, Cave Books, 454 p.

Palmer, A.N., 2009, Cave exploration as a guide to geologic research in the Appalachians: Journal of Cave and Karst Studies, v. 71, no.3, p. 180-192.

Solomon, D., Embry, I., Carson, B., Johnson, L., Painter, R., Sharpe, Jr., L., Toomey, R., and Byl, T.D., 2014, Transport of salt, trace metals, and organic chemicals from parking lot and road surfaces into Mammoth Cave, in Kuniansky, E.L., and Spangler, L.E., eds., U.S. Geological Survey Karst Interest Group Proceedings, Carlsbad, New Mexico, April 29-May 2, 2014: U.S. Geological Survey Scientific Investigations Report 2014-5035, p. 86, http://dx.doi.org/ $10.3133 /$ sir20145035.
Velasco, A.A., and de Velasco, E.J., 2010, Striving to diversify the geoscience workforce: EOS, Transactions, American Geophysical Union, v. 91, p. 289-291.

Villarejo, M., Barlow, A.E.L., Kogan, D., Veazey, B.D., and Sweeney, J.K., 2008, Encouraging minority undergraduates to choose science careers-Career paths survey results: CBE_-Life Sciences Education, American Society for Cell Biology, v. 7, p. 394-409.

Young, D., Trimboli, S.R., Toomey, R., III, and Byl, T.D., 2016, Undergraduate research projects help promote diversity in the geosciences, in Trimboli, S.R., Dodd, L.E., and Young, D., eds., Proceedings for celebrating the diversity of research in the Mammoth Cave region-11th Research Symposium at Mammoth Cave National Park, Mammoth Cave, KY, April 18-20, 2016: Mammoth Cave Research Symposia, p. 108-113, https://digitalcommons.wku.edu/cgi/viewcontent.cgi? article $=1167 \&$ context $=$ mc_reserch_symp. 


\title{
Next Generation Water Observing System Monitoring in the Little Lehigh Karst Basin, Pennsylvania
}

\author{
By Melinda J. Chapman, ${ }^{1}$ Brandon J. Fleming, ${ }^{1}$ Marla H. Stuckey, ${ }^{1}$ and Mark R. Beaver ${ }^{1}$ \\ 'U.S. Geological Survey, 215 Limekiln Road, New Cumberland, PA 17070. \\ (Emails: mjchap@usgs.gov; bjflemin@usgs.gov; mstuckey@usgs.gov; mrbeaver@usgs.gov)
}

\begin{abstract}
In federal fiscal year (FY) 2018, Congress enacted a new budget line item for the U.S. Geological Survey's (USGS) Water Mission Area, entitled "Next Generation Water Observing System" (NGWOS; https://www.usgs.gov/missionareas/water-resources/science/usgs-next-generation-waterobserving-system-ngwos; Eberts and others, 2019). Since then, the budget for this program has grown from an initial $\$ 1.5$ million in FY2018 to \$8.5 million appropriated in FY2019 and FY2020. The Delaware River Basin (DRB), which includes parts of the states of Delaware, New Jersey, Pennsylvania, and New York, was selected as the first "pilot" basin. The USGS has a critical role as the "Delaware River Master" as designated in a 1954 U.S. Supreme Court consent decree in support of conservation and flow management for the states of Delaware, New Jersey, New York, Pennsylvania, and the city of New York. The NGWOS program in the DRB will utilize an enhanced monitoring initiative including basin-wide scale monitoring, with nested intensive sub-basin scale monitoring and single-site innovation test beds. Continuous, discrete, and remotely sensed data will be collected. The program is intended to be long term, with operation and maintenance of stations for at least 10 or more years. Plans for NGWOS include the potential study of as many as 14 representative river basins across the United States.

As part of the first pilot within the new NGWOS program, existing USGS monitoring in the DRB was augmented with new stations positioned to fill gaps in drainage-basin size and land-use patterns to create a representative basin-wide network. Nested within this basin-wide network are intensively monitored sub-basins selected to represent the major physiographic provinces in the basin. In areas underlain by carbonate rock in the Valley and Ridge physiographic province, monitoring assets are being deployed in the Little Lehigh Creek basin in Lehigh County, Pennsylvania. Two existing real-time streamgages are being enhanced with water-quality monitoring for specific conductance and temperature, and six new streamgages are being installed to monitor water temperature, specific conductance, stage, and discharge
\end{abstract}

throughout the carbonate-dominated watershed. Within the Little Lehigh Creek basin, two large springs serve as public water-supply sources for the city of Allentown, which had an estimated population of about 121,000 in 2019 (https://www.c ensus.gov/quickfacts/fact/table/allentowncitypennsylvania/ PST045218\#PST045218). Schantz Spring will be monitored for flow, specific conductance, and temperature, including flow into the Lehigh County Authority distribution system, to provide a complete water accounting from the spring. Schantz Spring produces as much as 9 million gallons of water per day (Cadmus Group, Inc., 1998). This spring may be selected for daily water-use monitoring as part of the NGWOS or Water Resources Availability Program in the USGS.

Several surface-water features (rivers, creeks, lakes) have spring input from groundwater throughout the Little Lehigh Creek basin. Future short-term data collection activities that leverage the long-term infrastructure may include thermal surveys of known gaining/losing stream reaches, monitoring to evaluate the potential for stream depletion from water-supply wells, and isotopic analysis of precipitation and streamflow to characterize the seasonal distribution of recharge. Data collected through NGWOS in the Little Lehigh Creek basin are intended to provide transferable information to support water availability assessments and models in similar karst settings at local, regional, and national scales.

\section{References Cited}

Cadmus Group, Inc., 1998, Watershed assessment, Allentown, Pennsylvania: Report prepared for U.S. Environmental Protection Agency, Region 3, 188 p., https://www.dep.state.pa.us/dep/deputate/watermgt/wc/ subjects/srceprot/source/SourcewaterProtectionTraining/ cases/Allentown.pdf.

Eberts, S.M., Wagner, C.R., and Woodside, M.D., 2019, Water priorities for the Nation-The U.S. Geological Survey Next Generation Water Observing System: U.S. Geological Survey Fact Sheet 2019-3046, 2 p., https://pubs.er.usgs.gov/publication/fs20193046. 


\title{
History and Future Directions of Karst in StreamStats
}

\author{
By Katherine R. Kolb ${ }^{1}$ and Peter A. Steeves ${ }^{2}$
}

${ }^{1}$ U.S. Geological Survey, 810 Tyvola Road, Charlotte, NC 28217.

${ }^{2}$ U.S. Geological Survey, 10 Bearfoot Road, Northborough, MA 01532.

(Email: kkolb@usgs.gov)

\begin{abstract}
StreamStats (http://streamstats.usgs.gov) is a U.S. Geological Survey web-service-based geographic information systems (GIS) application that provides information used by engineers, hydrologists, managers, planners, and utilities to make informed decisions on waterand landscape-related resource management and assessment activities. StreamStats integrates multiple datasets, such as the National Hydrography Dataset (NHD), the Watershed Boundary Dataset (WBD), and 3D Elevation Program (3DEP) lidar-derived elevation data, to allow users to delineate a watershed for a stream point of interest. Karst terrain
\end{abstract}

sources contribute flow to several regional project areas in StreamStats. These regional project areas have been handled in several ways, from creating sink/endpoints in the hydrologic network GIS data to treating all flow as overland flow based on available partner data. In order to provide the best available data to our users, StreamStats is exploring future directions to better model karst-involved flow through watersheds. StreamStats has recently implemented tools that allow for connections between upstream contributing areas and downstream disconnected streams. These tools are currently being used in StreamStats to connect and model subsurface storm drains in St. Louis, Missouri, although these tools could also be applied to mapped subsurface karst flow. 


\title{
Waters of the United States (WOTUS) Revisions Imperil Streams and Source Waters for Vulnerable Karst Aquifers
}

\author{
By Sid Jones, ${ }^{1}$ Gareth Davies, ${ }^{2}$ John Hoffelt, ${ }^{3}$ and Terri Brown ${ }^{4}$ \\ ${ }^{1}$ Retired, State of Tennessee. \\ ${ }^{2}$ Tennessee Department of Environment and Conservation, Oak Ridge, TN 37830. \\ ${ }^{3}$ Tennessee Department of Environment and Conservation, Nashville, TN 37202. \\ ${ }^{4}$ University of Virginia's College at Wise, Department of Natural Sciences, Wise, VA 24293. \\ (Email: sjones5@utk.edu)
}

\begin{abstract}
The U.S. Geological Survey estimates that 18 percent of the United States is underlain by soluble rocks, and all 50 states and at least 14 territories have the potential for karst or pseudokarst development. In Tennessee, soluble carbonate rocks are subaerially exposed over much of the state, resulting in the development of abundant karst features, including over 10,000 known caves. Sinkhole plains with internal drainage have developed on portions of the Highland Rim and the Valley and Ridge physiographic provinces of the state, but fluviokarstic terrains formed by both fluvial and karst processes are more common. It is common in these hydrologic settings for the base flow of surface streams to be pirated into the subsurface through karst features such as sinking streams where surface water and groundwater directly interact. Flow in Tennessee karst aquifers is characterized by (a) relatively short groundwater residence times (hours to weeks), (b) preferential flow patterns that are not easily determined from potentiometric data, and (c) convergent subsurface flow paths that range up to 15 kilometers from recharge areas to springs.

The regulatory structure in Tennessee has some flexibility to address potential impacts of practices such as unconventional oil and gas extraction and underground injection on surface water as well as groundwater, but has not, for the most part, addressed the issues caused by sinking streams and rapid groundwater flow with either rules or guidance. A number of springs used for municipal water supply in Tennessee are considered to be under the influence of surface water, and some have been impacted by land
\end{abstract}

development and land use practices that have not considered the occurrence of karst. Many more private wells and springs have been impacted by land development, waste disposal, or wastewater discharges in karst terrain.

Aquifers are not considered jurisdictional waters under the Federal Clean Water Act (CWA); however, waters recharged through karst historically have been afforded some protections by the U.S. Environmental Protection Agency (EPA) as "direct hydrologic connections." This interpretation of the CWA recognized the potential for contaminant transport to receiving streams and lakes via subsurface flow and allowed a case-by-case determination of the applicability of the Act in karst areas such as Tennessee. In April 2019, the EPA issued an interpretive statement concluding that Congress had excluded releases of pollutants to groundwater from the Act's permitting requirements and instead left regulation of those releases to the states and EPA's other statutory authorities. Adopted in January 2020, the revisions to the CWA also remove protections for "isolated wetlands" (less than 5 acres). There are a number of such wetlands located in dolines (sinkholes) on the sinkhole plain of the Eastern Highland Rim in Tennessee, which function as natural stormwater collection basins and focused recharge points for springs and headwater streams. Loss of protection for these wetlands will have a detrimental impact on aquatic ecology and stream quality, and exacerbate the problem of flooding. Given the broad distribution of karst and pseudokarst across the country, these revisions appear inconsistent with the goals of the CWA and increase the probability of surface-water impairment, property damage, habitat loss, and drinking-water contamination across a significant portion of the country. 


\title{
Abstracts-Karst in Tennessee
}

\section{A Summary of Karst Regions in Tennessee}

\author{
By Michael Bradley ${ }^{1}$
}

${ }^{1}$ Emeritus, U.S. Geological Survey.

(Email: mbradley3@gmail.com)

\begin{abstract}
Karst terrains are characteristic of much of the eastern two thirds of Tennessee. The occurrence of karst features in Tennessee affects property development, infrastructure, water supply, contaminant transport, and flood and drought planning in Middle and East Tennessee. Karst aquifers in Tennessee provided close to 40 million gallons per day to public water systems in 2015 with the carbonate formations in the Valley and Ridge province of East Tennessee being the second most productive aquifer in the state. The interconnection between surface water and karst systems results in offstream flooding in Tennessee. Sinkhole collapse and the potential for sinkhole collapse have affected subdivisions in several regions in the state. The importance of karst resources to the hydrology and ecology of Tennessee has only been fully defined in relatively small areas. Additional work is needed to further evaluate karst features relative to public water supplies and susceptibility of the systems to contamination, karst hydrology and ecology along the Cumberland Plateau escarpment, and impacts and controls of sinkhole flooding.
\end{abstract}

\section{Introduction}

Carbonate-rock outcrops, sinkholes, disappearing streams, caves, and other features of karst terrains are important components of the ecologic, geologic, and hydrologic characteristics of the eastern two thirds of Tennessee. The occurrence of karst terrain in Tennessee has an effect on property development, infrastructure, water supply, contaminant transport, and flood and drought planning. Tennessee has more than 10,000 documented caves (Niemiller and others, 2016; Tennessee Cave Survey [TCS], 2020), making up more than 20 percent of the documented caves in the United States (Niemiller and others, 2016). The primary karst regions of Tennessee occur in the eastern two thirds of the state and include the Highland Rim, Central Basin, and Valley and Ridge physiographic provinces (fig. 1). The escarpments on the east and west sides of the Cumberland Plateau are also significant in the occurrence and development of karst features in Tennessee. Caves and karst features also occur along the Western Valley of the Tennessee River and in the Blue Ridge Mountains in East Tennessee.

The physiographic provinces and the underlying geology have been used to distinguish the principal aquifers in Tennessee (fig. 2) and provide a useful framework for describing the karst regions in the state. Caves and other karst features occur predominantly in the carbonate formations and include units from Cambrian to Mississippian in age. Some cave-like features, such as rock houses in the Pennsylvanian sandstones of the Cumberland Plateau and pseudo-karst features in West Tennessee, could be included in the overall cave numbers; however, this discussion of karst in Tennessee will focus on the typical karst features found in carbonate rocks. The karst regions of Middle and East Tennessee provide important sources of water for public and domestic water supplies (Bradley and Hollyday, 1985).

Cave maps for Tennessee, based on data from the Tennessee Cave Survey (TCS, 2020), show the distribution of caves and karst features across the state and provide information on cave occurrence by physiographic region (fig. 3). The karst regions occur primarily in the Highland Rim (Mississippian carbonates), Central Basin (Ordovician carbonates), and Valley and Ridge (Cambrian-Ordovician carbonates) physiographic provinces. The cave distribution (Sutherland, 2016) shows the highest density of caves by county and by 1:24,000-scale topographic quadrangle maps occurring along the western escarpment of the Cumberland Plateau. Caves and karst features in the Blue Ridge Mountains occur in carbonate valleys, coves, and fensters (windows) that occur along the boundary between the Valley and Ridge and the Precambrian metamorphic rocks of the Blue Ridge. 


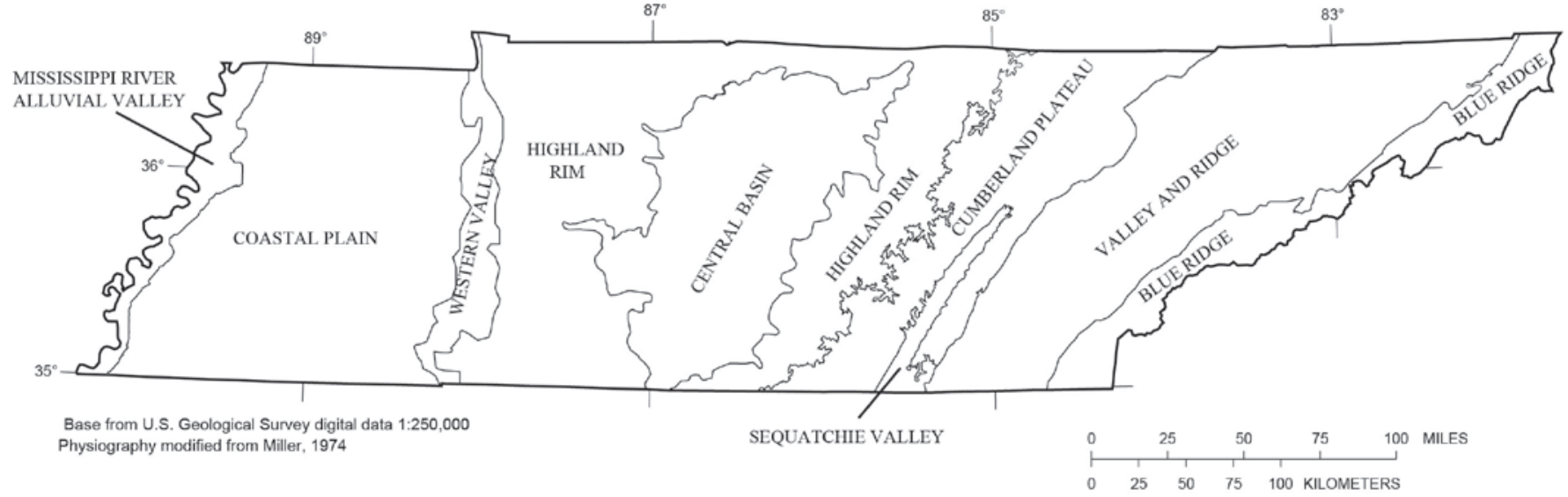

Figure 1. Physiographic provinces of Tennessee.

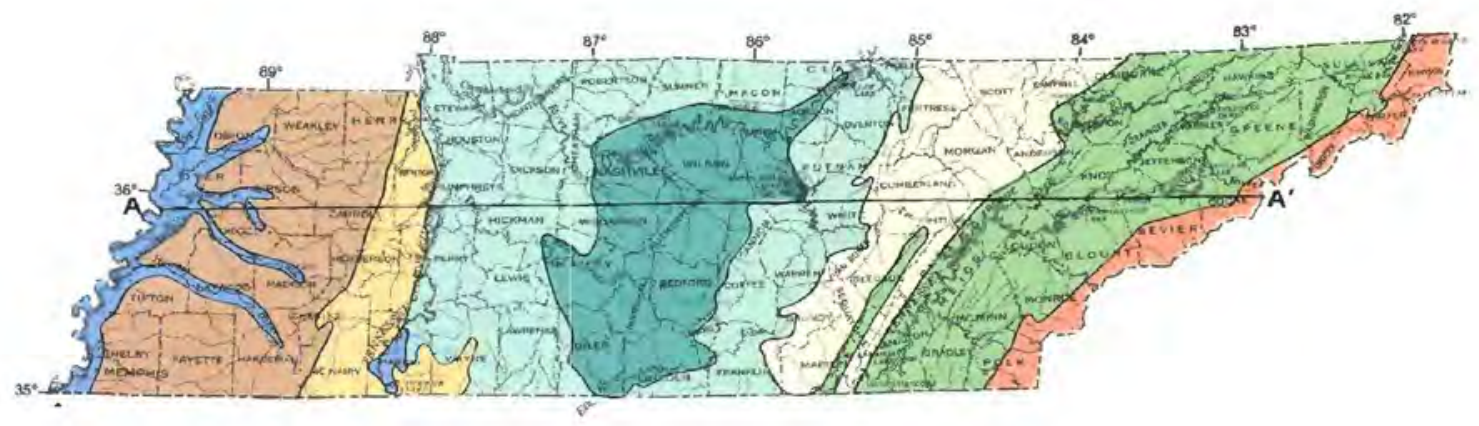

EXPLANATION
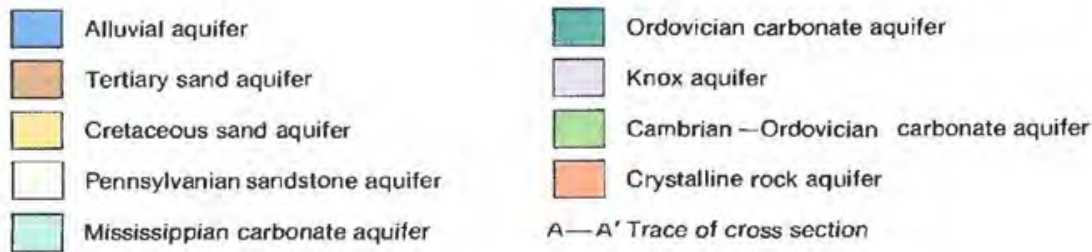

A- $A^{\prime}$ Trace of cross section

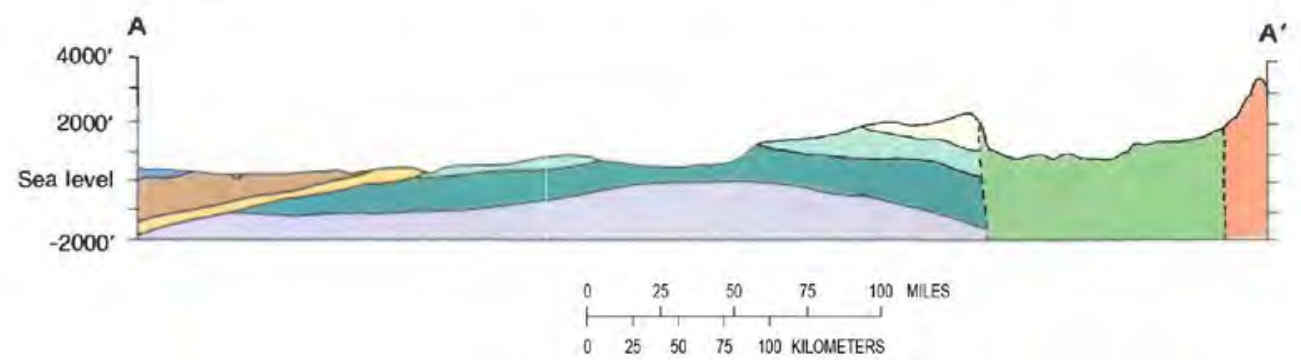

Modified from Bradlev and Hollydav. 1985

Figure 2. Principal aquifers in Tennessee. 


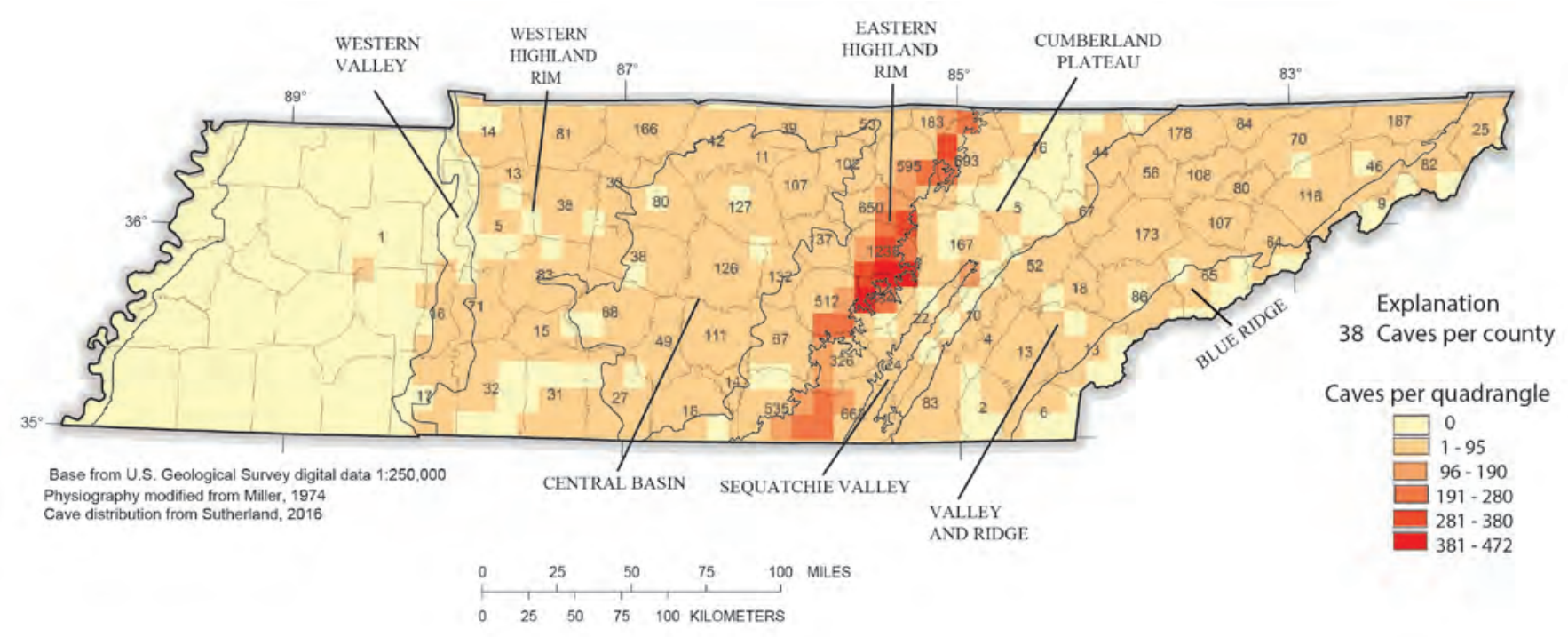

Figure 3. Distribution of caves and karst regions in Tennessee.

\section{Karst Regions of Tennessee}

The karst regions of Tennessee are described based on the underlying geology and the physiographic province. The TCS has documented more than 10,000 caves in Tennessee (TCS, 2020). The eastern and western escarpments of the Cumberland Plateau include about 56 percent of the documented caves in Tennessee (fig. 4). The other karst regions (and percentage of Tennessee caves) include the Highland Rim (18 percent), Valley and Ridge (16 percent), Central Basin (4 percent), Sequatchie Valley (2 percent), and Blue Ridge Mountains (1 percent). Although the Blue Ridge has a small number of caves, the region includes the deepest caves in Tennessee (Nolfi, 2011). Areas with minor karst or pseudo-karst features (Coastal Plain of West Tennessee, Western Valley of the Tennessee River, Cumberland Plateau sandstones) are not included in the descriptions of karst regions in Tennessee.

\section{Highland Rim—Mississippian Carbonates}

The Mississippian carbonate formations occur in the Highland Rim province in Middle Tennessee and primarily consist of limestone and dolomite overlain by a relatively thick regolith (Marcher and others, 1964; Bradley, 1984). Although mapped as a single physiographic province, the eastern and western sections of the Highland Rim have different geologic and hydrologic characteristics. The difference between the two sections is also seen in the differences in documented cave occurrences (Sutherland, 2016; TCS, 2020). The karst features, and similarities and differences for the western and eastern sections of the Highland Rim are discussed below. Karst features in the coves and valleys along the escarpment between the eastern Highland Rim and the Cumberland Plateau are discussed below under the "Cumberland Plateau Escarpments." The TCS has documented more than 1,900 caves in the Highland Rim province (TCS, 2020). The caves of the Highland Rim average 800 feet (ft) in length and about $20 \mathrm{ft}$ in depth, and the caves occurring along the escarpment of the Highland Rim average about $960 \mathrm{ft}$ in length and about $30 \mathrm{ft}$ in depth (TCS, 2020).

The western Highland Rim is primarily underlain by the Mississippian Fort Payne Formation and Warsaw Limestone, with the St. Louis Limestone occurring in the northern part of the western Highland Rim. The northern part of the western Highland Rim is a continuation of the Pennyroyal Plain karst region in Kentucky. The Mississippian formations generally become younger progressing to the north, with the St. Louis and Ste. Genevieve Limestones exposed along the Tennessee-Kentucky border (Kemmerly, 1982). The number of caves per county increases in the northern counties of the western Highland Rim (fig. 3), reflecting the occurrence of the St. Louis and Ste. Genevieve Limestones. Continuing north into Kentucky, the geology transitions to the younger units of the Mammoth Cave region. The karst region along the Tennessee-Kentucky border includes areas near Clarksville, Tennessee, where suburban development and public infrastructure have been affected by sinkhole flooding (fig. 5). 


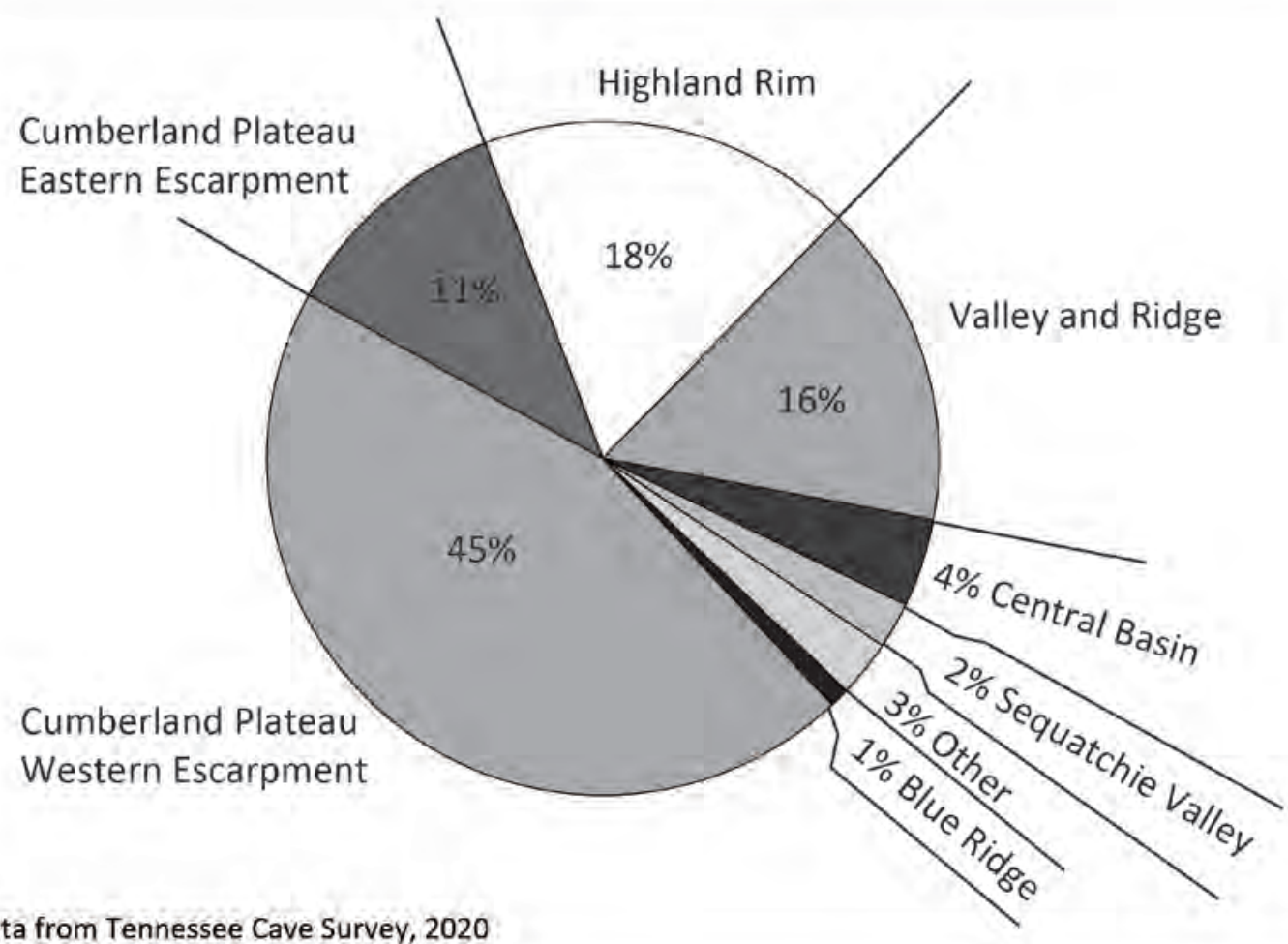

Cave data from Tennessee Cave Survey, 2020

Figure 4. Distribution of caves in Tennessee by physiographic province.

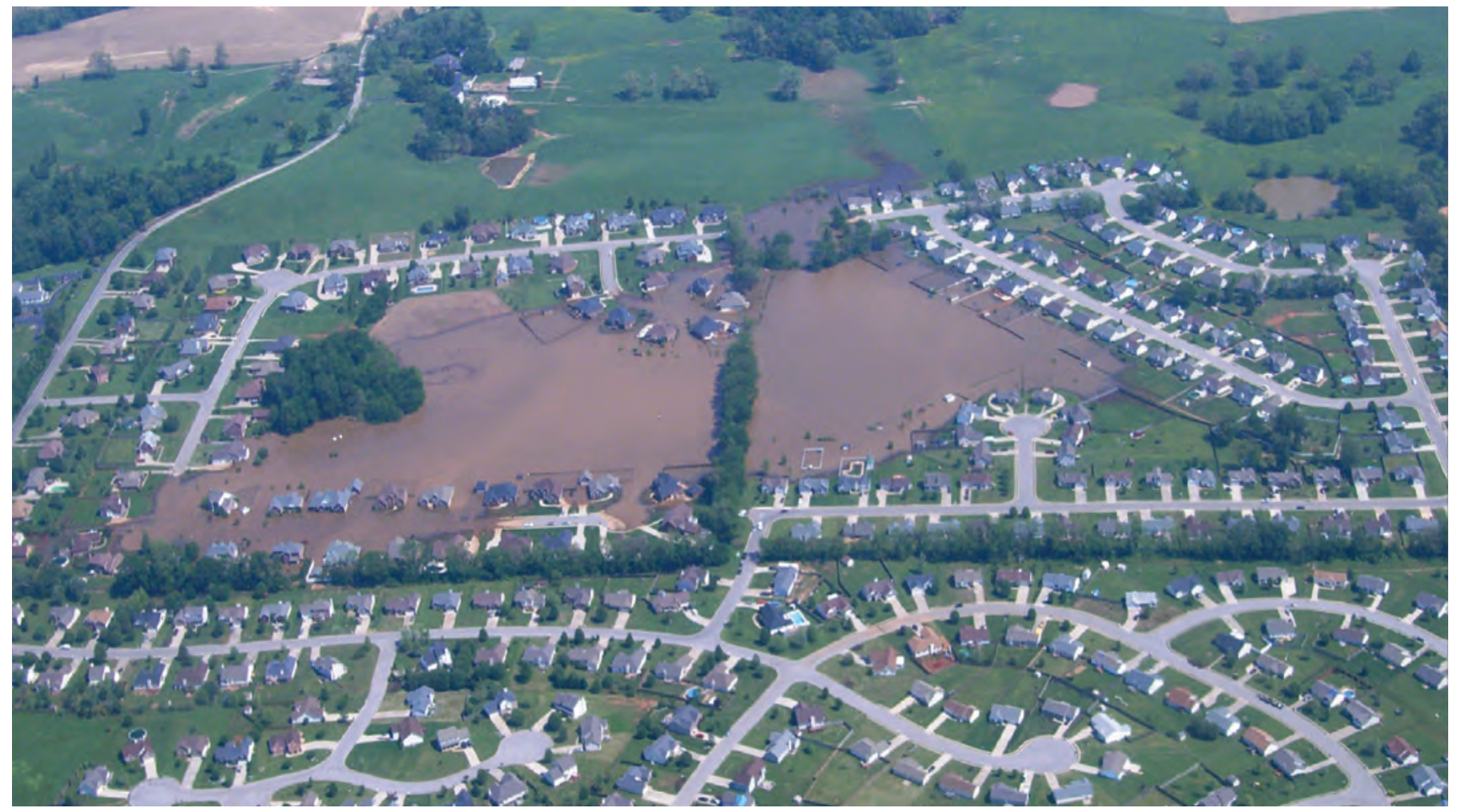

Figure 5. Aerial view of sinkhole flooding at a subdivision underlain by the St. Louis Limestone near Clarksville, Tennessee, in the northern Highland Rim. Photograph taken May 5, 2010, by M. Bradley, U.S. Geological Survey. 
Most of the eastern Highland Rim is also underlain by the Fort Payne Formation and Warsaw Limestone, with the Warsaw and St. Louis Limestones occurring in the northern part of the eastern Highland Rim. In some areas of the southeastern part of the Highland Rim, gravel zones in the regolith are formed from the weathered Fort Payne Formation and can result in high production wells (Burchett and Hollyday, 1974). To the east, the units become younger approaching the Cumberland Plateau, and the eastern Highland Rim is underlain by the Monteagle and Bangor Limestones and the Hartselle Formation (Brahana and Bradley, 1986). Continuing east, the Mississippian carbonates are overlain by the Mississippian Pennington Formation and the Pennsylvanian sandstones and shales of the Cumberland Plateau.

In 2015, Mississippian carbonates supplied about 17 million gallons per day (Mgal/d) to public water systems in Tennessee and was used by about 218,000 people (TN $\mathrm{H} 2 \mathrm{O}, 2018)$. Groundwater use from Mississippian aquifers by public water systems in Franklin, Lawrence, Lincoln, and Montgomery Counties exceeded $2 \mathrm{Mgal} / \mathrm{d}$. Groundwater production from springs and wells in the eastern Highland Rim has been used to meet the irrigation needs for a growing nursery industry (TN H2O, 2018). The Mississippian carbonates are also important sources of drinking water for rural domestic users.

\section{Central Basin-Ordovician Carbonates}

The Ordovician carbonate aquifer consists of limestone and dolomite in the Central Basin of Middle Tennessee. The topographic Central Basin is a structural dome, the Nashville Dome, an extension of the Cincinnati Arch that includes the Jessamine Dome in central Kentucky (Bradley and Parris, 2014). The Ordovician formations are generally less resistant to erosion than the Mississippian formations, and karst processes played a role in the relatively rapid erosion and formation of the Central Basin (Reesman and Godfrey, 1972; Crawford, 1987). The Central Basin has about 450 caves documented by the TCS (fig. 3), with an average length of about $640 \mathrm{ft}$ and an average depth of about $30 \mathrm{ft}$ (TCS, 2020).

The carbonates of the Central Basin are generally thin bedded, with intervening shale and shaley limestone. The Central Basin typically has thin soil cover and open sinkholes and fractures that can allow very rapid movement of water and contaminants into the subsurface. Karst features near major streams and rivers can flood in offstream areas because of flooding on the river and hydrologic connections to the karst areas (Law 2002; Bradley and Hileman, 2006). Investigations in the Murfreesboro area of the Central Basin identified three major types of sinkhole flooding including shallow "pan" sinkholes and deep sinkholes that may be connected to underlying caves and conduits (fig. 6).

The principal carbonate formations in the Central Basin from youngest to oldest, are the Ordovician Bigby-Cannon Formation, Hermitage Formation, Carters Limestone, Ridley Formation, and the Murfreesboro Limestone (Brahana and Bradley, 1985a). The karst aquifers in the Central Basin are used for rural domestic and public supply. About 2.4 Mgal/d are pumped from the Ordovician carbonates by public water systems. Springs issuing from the Ordovician carbonates are also important sources of water for the George Dickel and Jack Daniels Distilleries. The regolith overlying the limestone is much thinner in the Central Basin and in places can be less than $3 \mathrm{ft}$ thick with bedrock exposed at land surface. Because of the thin regolith and presence of karst features (sinkholes, disappearing streams, and caves), the groundwater from the aquifer is very susceptible to contamination and can have high concentrations of nutrients and bacteria (Brahana and Bradley, 1985a).

\section{Cumberland Plateau Escarpments}

The Cumberland Plateau province is capped by Pennsylvanian formations, primarily sandstone, shale, and some conglomerate. The Cumberland Plateau is about 600 to more than 1,000 ft higher in elevation than the Highland Rim province to the west and the Valley and Ridge province to the east. The soils and formations of the Cumberland Plateau have little buffering capacity, and surface water and groundwater can be slightly acidic (Brahana, Macy, and others, 1986). Along the edge of the Cumberland Plateau, the underlying carbonates are exposed and eroded mechanically and chemically (Crawford, 1987). The elevation difference along the escarpments, steep hydraulic gradients, and slightly acidic water create a narrow, but extremely important karst region with large springs and stream resurgences and a very high density of caves (fig. 7). Despite its relatively small area in comparison with the overall physiographic region, the western escarpment of the Cumberland Plateau has the highest number and highest density of documented caves, with cave density ranging from about 200 to about 470 caves on a 1:24,000-scale topographic quadrangle map (Sutherland, 2016) (fig. 3). The TCS has documented more than 4,800 caves along the western escarpment of the Cumberland Plateau and more than 1,200 caves along the eastern escarpment of the Plateau (TCS, 2020). Caves in this region are developed primarily in the Bangor Limestone (1,700 caves, 16 percent), Monteagle Limestone (1,670 caves, 15.6 percent), and the combined Hartsell Formation and Monteagle Limestone (1,870 caves, 17.5 percent) (TCS, 2020). 


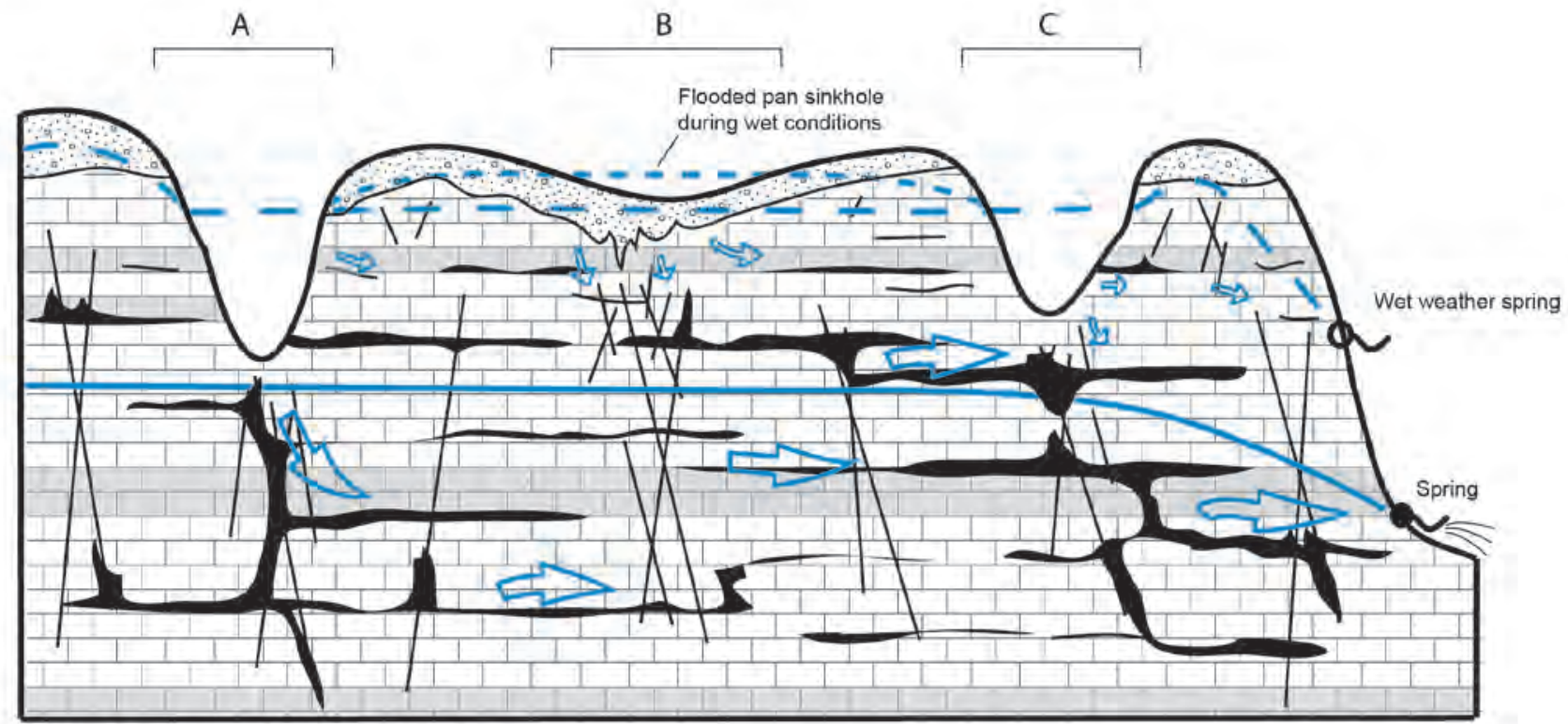

From Bradley and Hileman, 2006

\section{SINKHOLE FLOODING MODEL TYPE}
A DEEP SINKHOLE WITH HIGH
CONNECTIVITY TO GROUND WATER CONDUIT SYSTEM CONNECTIVITY TO GROUND- WATER CONDUIT SYSTEM
B PANSINKHOLE WITHLOW
C DEEP SINKHOLE WITHLOW CONNECTIVITY TO GROUND- WATER CONDUIT SYSTEM

\section{EXPLANATION}

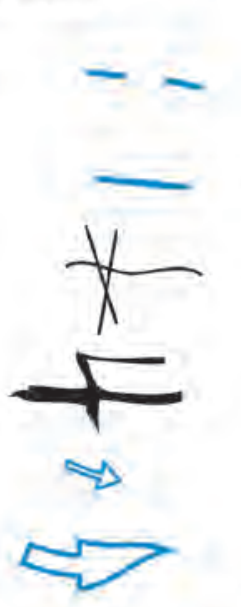
WATER TABLE DURING WET OR
FLOODED CONDITIONS

WATER TABLE DURING DRY CONDITIONS

FRACTURES AND THIN BEDDING PLANE OPENINGS AND SOLUTION FEATURES

LARGE, INTERCONNECTED CONDUITS AND FRACTURES IN BEDROCK

MINOR GROUNDWATER FLOW COMPONENT

MAJOR GROUNDWATER FLOW COMPONENT
LITHOLOGY

SOIL OR REGOLITH

LIMESTONE

SHALEY LIMESTONE

Figure 6. Conceptual model of karst features and sinkhole flooding in the Ordovician limestones of the Central Basin in Tennessee.

The western escarpment of the Cumberland Plateau is arguably the most critical karst and cave resource in Tennessee. The number of caves, more than 4,800, make up about 45 percent of the total number of documented caves in Tennessee (TCS, 2020). Some of the largest springs in Tennessee also occur in this region (Ben Miller, U.S. Geological Survey, oral commun., June 2019), yet little data are available to fully define the hydrology and recharge areas of these large springs. The effects of legacy coal mining and acid-mine drainage have also had an adverse impact on streams and springs draining off the Cumberland Plateau and into the underlying carbonates (Nichols and Bulow, 1973; O'Bara and Estes, 1985). Several streams along the northeastern boundary between the Highland Rim and Cumberland Plateau are disappearing streams, yet the impact of the acid-mine drainage on the karst hydrologic system and the cave biota are not known. 


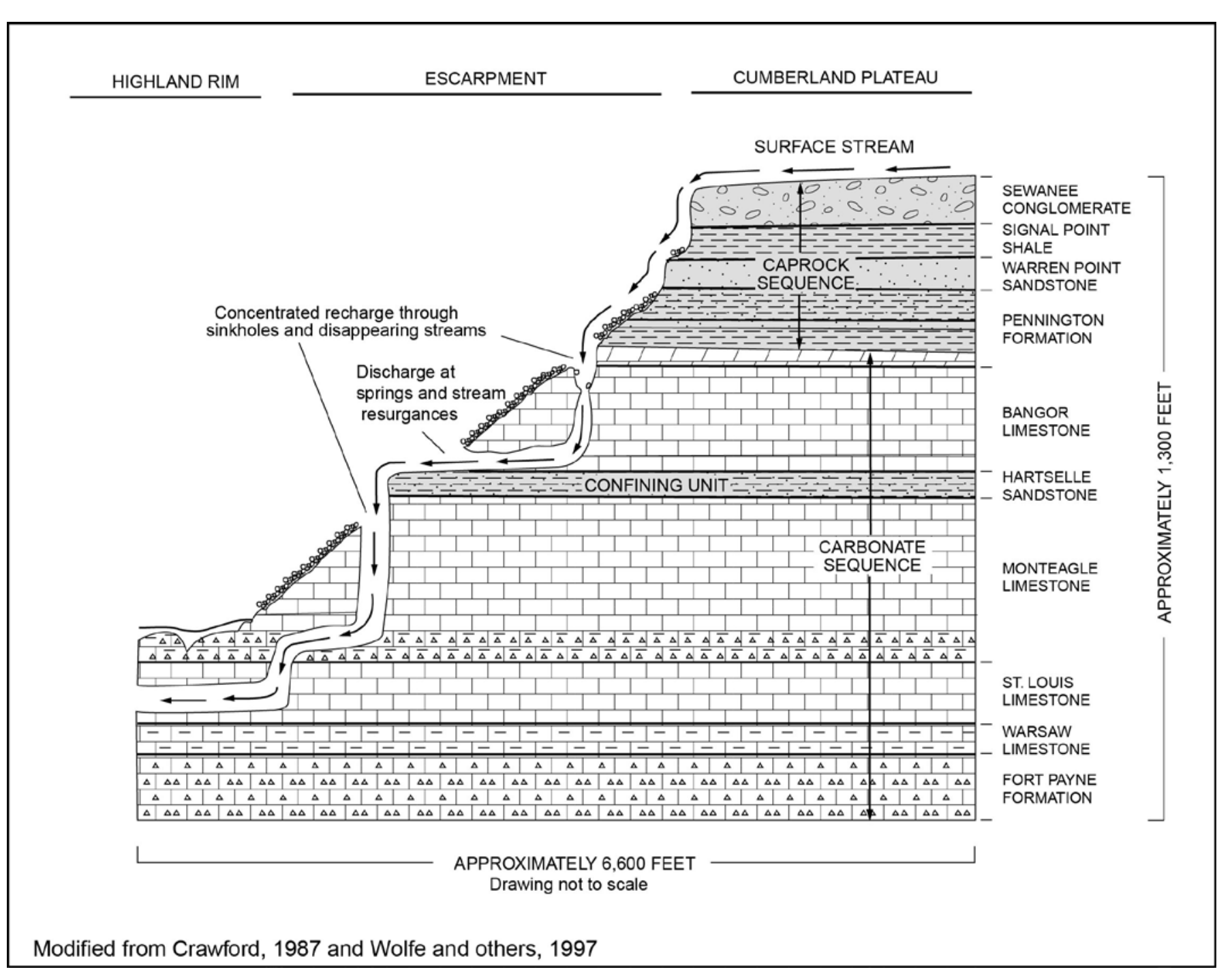

Figure 7. Conceptual model of karst development along the western escarpment of the Cumberland Plateau.

\section{Valley and Ridge-Cambrian-Ordovician Carbonates}

The Valley and Ridge province is characterized by sub-parallel, northeast-trending, alternating valleys and ridges formed by the strongly folded and faulted structure created by multiple mountain-building events that formed the Appalachian Mountains. The formations were fractured and moved several miles northwest along the major thrust faults, resulting in a repetition of the geologic formations and the development of the characteristic "valley and ridge" topography. The major folds and thrust faults control the occurrence and distribution of the carbonate rocks and karst features in East Tennessee. The principal carbonate-rock units include the Chickamauga Limestone, the Knox Group, and the Honaker Dolomite of the Conasauga Group (Brahana, Mulderink, and others, 1986; Hollyday and Hileman, 1996).
The TCS has documented more than 1,600 caves in the Valley and Ridge province, about 16 percent of the total number of caves in Tennessee (TCS, 2020). The caves in the Valley and Ridge have an average length of $511 \mathrm{ft}$ and an average depth of $36 \mathrm{ft}$, and only 23 caves have a length of more than 1 mile (TCS, 2020). Caves and karst features develop along the ridges where resistant units of the Knox Group are present, and in the valleys where more soluble carbonates are overlain by alluvial and colluvial deposits (fig. 8).

The carbonate aquifers in the Valley and Ridge province were the second most used groundwater system in Tennessee in 2015 (TN H2O, 2018). Public water systems in East Tennessee produced about $39 \mathrm{Mgal} / \mathrm{d}$ from the Valley and Ridge aquifers to supply water to about 565,000 people. Major areas of groundwater withdrawal by public water systems in 2015 included Bradley (2.2 Mgal/d), Carter (5.9 Mgal/d), Hamilton (11.1 Mgal/d), and Washington (2.7 Mgal/d) Counties (TN H2O, 2018). 


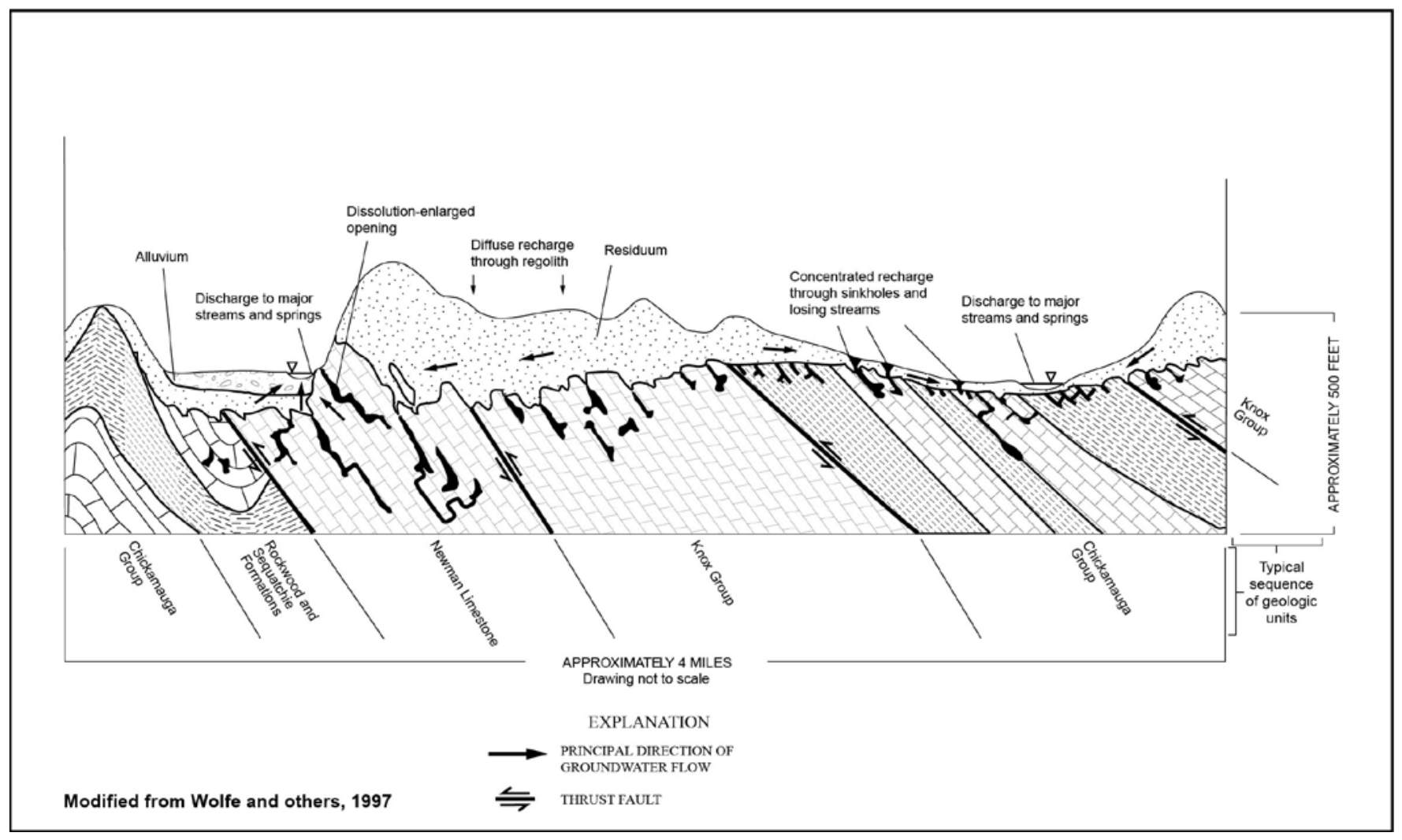

Figure 8. Conceptual model of karst hydrogeology and groundwater movement in the Valley and Ridge province, East Tennessee.

\section{Sequatchie Valley-Cambrian-Ordovician Carbonates}

The Sequatchie Valley is generally mapped as part of the Valley and Ridge province because of the similarities in stratigraphy and structure (Bradley and Hollyday, 1985). The Sequatchie Valley is an anticlinal valley formed along a major thrust fault, the Sequatchie Fault, with the Cambrian-Ordovician Knox Group exposed at land surface in the center of the valley (Miller, 1974). The Sequatchie Valley is the westernmost extension of the structural deformation of East Tennessee. Karst features in the Knox Group in the Sequatchie Valley are similar to the features developed in the Knox Group of the Valley and Ridge. Karst features that develop along the escarpments and in stream valleys entering the Sequatchie Valley are similar to the features developed along the Cumberland Plateau escarpments. Only about 240 caves have been documented by the TCS in the Sequatchie Valley (TCS, 2020). However, a higher percentage of caves deeper than $400 \mathrm{ft}$ (3 percent) and cave pits deeper than $100 \mathrm{ft}$ ( 5 percent) are present in Sequatchie Valley than in the other karst regions (TCS, 2020).

\section{Blue Ridge — Carbonate and Metasedimentary Rocks}

The crystalline-rock aquifer of the Blue Ridge Mountains includes fractured igneous, metamorphic, and metasedimentary rocks. In some valleys and coves along the western edge of the Blue Ridge province, dolomite and limestone are present and karst features have developed. The karst features occur in the valleys where the carbonate rocks are adjacent to the crystalline formations and in coves that formed as fensters (structural windows) where these older crystalline rocks have been thrust up and over the younger carbonate rocks (Hatcher and Thomas, 1989; Hollyday and Hileman, 1996; Bradley and others, 2018; Miller and others, 2018). Subsequent erosion through the crystalline rocks exposed the carbonate rocks where solution and karst development have taken place. Cades Cove in Great Smoky Mountains National Park is an example of a karst fenster where the Precambrian Cades and Elkmont Sandstones and the Metcalf Phyllite were thrust over the younger Paleozoic Jonesboro Limestone (fig. 9). 


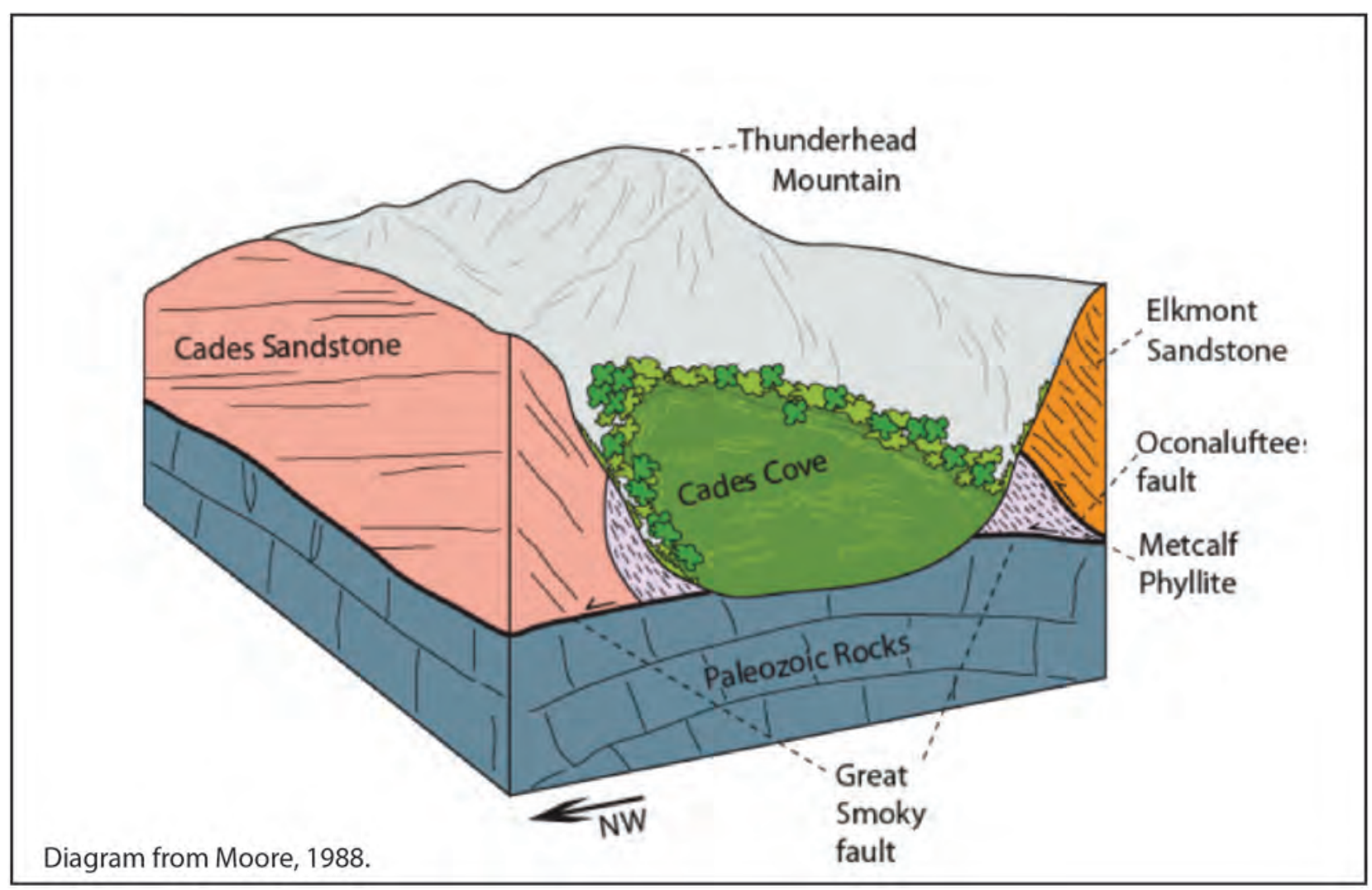

Figure 9. Block diagram of Cades Cove, a karst fenster in western Great Smoky Mountains National Park.

The high relief and structural deformation along the contact between the Cambrian-Ordovician carbonates and the Precambrian crystalline rocks have resulted in the formation of several caves exceeding $400 \mathrm{ft}$ in depth. Bull Cave $(924 \mathrm{ft})$ and Rich Mountain Blowhole (840 ft), occurring between the Great Smoky Mountains and Tuckaleechee Cove, are the two deepest caves in Tennessee and among the deepest caves in the eastern United States (Nolfi, 2011). Data from the TCS (2020) document the occurrence of about 160 caves in the Blue Ridge province with 3 percent of the caves deeper than $400 \mathrm{ft}$.

\section{Knox Paleokarst}

The Knox aquifer is defined as the paleokarst occurring in the upper Knox Group in Middle Tennessee but does not include the Knox Group in East Tennessee. The Knox aquifer occurs at depths of about 600 to about 2,000 ft (Newcome and Smith, 1962; Brahana and Bradley, 1985b). Paleokarst is developed in the upper 200 to $300 \mathrm{ft}$ of the Knox Group, primarily in the Ordovician Mascot Dolomite. The paleokarst provides an important source of domestic water supply in areas where the shallower aquifers do not provide sufficient groundwater (Brahana and Bradley, 1985b). Similar to the
Knox Group in East Tennessee, the paleokarst zone in the Knox in Middle Tennessee has been mined as a source of sphalerite formed in collapse breccia and other paleokarst features (Seal and others, 1985). Water-well data reported by well drillers to the Tennessee Department of Environment and Conservation Water Well program indicate that about 5 to 7 percent of the rural domestic wells in the Central Basin are completed at depths greater than $700 \mathrm{ft}$ (Brahana and Bradley, 1985b).

\section{Groundwater Withdrawals}

Groundwater in the karst regions of Tennessee is an important resource for public water supply and domestic self-supply. In total, groundwater in Tennessee provided about $299 \mathrm{Mgal} / \mathrm{d}$ in 2015 for public water systems (256 $\mathrm{Mgal} / \mathrm{d}$ ) and domestic self-supply (43 Mgal/d) to about 2.87 million people (U.S. Geological Survey, 2020). The majority of the groundwater used in Tennessee is withdrawn from unconsolidated sands in West Tennessee. Groundwater from karst aquifers provided about $58 \mathrm{Mgal} / \mathrm{d}$ in 2015 for public water-supply use in Middle and East Tennessee (table 1). 
Table 1. Withdrawals for public water supply from the principal aquifers in Tennessee, 2015.

[Karst aquifers are shaded. Data compiled from Tennessee Department of Environment and Conservation-Division of Water Resources]

\begin{tabular}{lc}
\hline \multicolumn{1}{c}{ Aquifer system } & $\begin{array}{c}\text { Withdrawals for public } \\
\text { water supply, in million } \\
\text { gallons per day }\end{array}$ \\
\hline Alluvial aquifers & 0 \\
Mississippi River alluvial aquifer & 1.87 \\
Western Valley of the Tennessee River & \\
Tertiary sand aquifer system & 159 \\
Memphis aquifer & 2.97 \\
Fort Pillow aquifer & 26.54 \\
Tertiary undifferentiated & 6.95 \\
Cretaceous sand aquifer system & 0.37 \\
Pennsylvanian sandstone aquifer system & 16.63 \\
Mississippian carbonate aquifer system & 2.4 \\
Ordovician carbonate aquifer system & 0 \\
Knox aquifer, Middle Tennessee & 36.8 \\
Valley and Ridge aquifer system & \\
Blue Ridge aquifer system & 0.24 \\
Crystalline-rock aquifer & 2.12 \\
\hline Carbonate aquifer & \\
\hline
\end{tabular}

The distribution of public water systems producing water from wells and springs in Tennessee during 2015 is shown on figure 10. The importance of the karst aquifers, especially in the Valley and Ridge province is shown by the number of public water systems utilizing groundwater (TN H2O, 2018). An evaluation of groundwater quality and sinkhole density by the U.S. Geological Survey showed that areas with high and medium sinkhole density had higher concentrations of nitrate and pesticides than areas of low sinkhole density (Lindsey and others, 2009). The occurrence of caves and karst features in East Tennessee, the use of karst aquifers for public water supply, and the susceptibility of the systems to contamination has not been fully evaluated.

\section{Summary}

Sinkholes, disappearing streams, caves, and other karst features are important components of the ecologic, geologic, and hydrologic characteristics of the eastern two thirds of Tennessee. More than 10,000 caves have been documented in Tennessee, making up more than 20 percent of the total number of known caves in the United States. The most important karst region in Tennessee, in terms of the number of caves, is the area along and near the western escarpment of the Cumberland Plateau. The other primary karst regions of Tennessee occur in the Highland Rim, Central Basin, and Valley and Ridge physiographic provinces, and in the coves of the Blue Ridge Mountains.

The occurrence of karst terrain has an effect on property development, infrastructure, water supply, contaminant transport, and flood and drought planning in Middle and East Tennessee. Karst aquifers in Tennessee provided close to 40 million gallons per day to public water systems in 2015. The carbonate formations in the Valley and Ridge province of East Tennessee are the second most productive aquifer in the state. The interconnection between surface water and karst systems also results in offstream flooding in Tennessee, especially in the Clarksville area (Mississippian carbonates, Highland Rim) and the Murfreesboro area (Ordovician carbonates, Central Basin). Sinkhole collapse and the potential for sinkhole collapse have affected subdivisions in the Central Basin (Nashville and Murfreesboro areas) and in the Valley and Ridge (Knoxville area). Cave features also provide habitat for unique species in Tennessee.

The karst features described in this paper have had a disproportionate influence on the water resources, land development, and ecology in Tennessee. However, the importance of karst resources to the hydrology and ecology of Tennessee has only been defined in relatively small areas. Additional work is needed to further evaluate karst features relative to public water supplies and susceptibility of the systems to contamination, karst hydrology and ecology along the Cumberland Plateau escarpment, and impacts and controls of sinkhole flooding. 


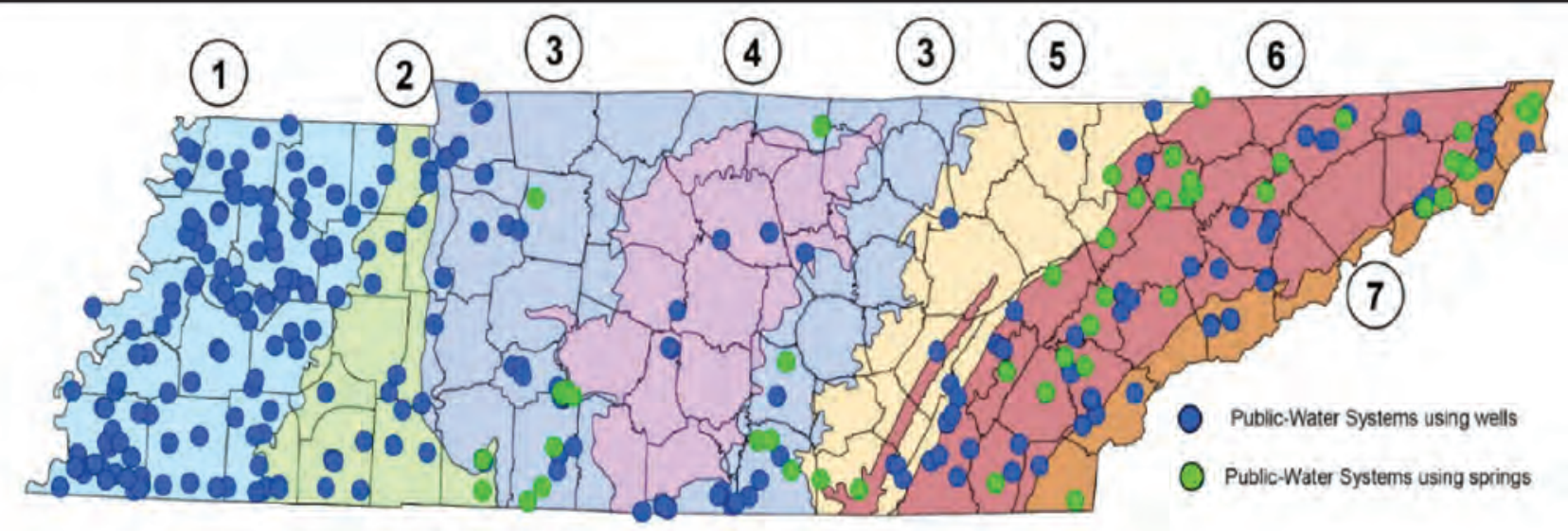

EXPLANATION

\begin{tabular}{l|l|}
\hline 1 & Tert Sand \\
\hline 2 & Cret Sand \\
\hline 3 & Highland Rim \\
\hline 4 & Central Basin \\
\hline 5 & Cumberland Plat \\
\hline 6 & Valley-Ridge \\
\hline 7 & Blue Ridge
\end{tabular}

Tertiary sand aquifer - most productive aquifer in Tennessee. Capable of sustaining very large withdrawals (>20 Mgal/d) for public-water systems.

Cretaceous sand aquifer - generally a productive aquifer in Tennessee.

Capable of sustaining large withdrawals ( $3-5 \mathrm{Mgal} / \mathrm{d})$ for public-water systems except in areas near the eastern boundary or where sands are thin.

Highland Rim - Limestone aquifers, can be productive locally. Currently supporting public-water systems using 0.3 to more than $1 \mathrm{Mgal} / \mathrm{d}$.

Central Basin - Limited capacity to sustain public-water supply. Currently supporting public-water systems using less than $0.25 \mathrm{Mgal} / \mathrm{d}$. Can supply $>1 \mathrm{Mgal} / \mathrm{d}$ in local areas where the aquifer connects to surface water.

Cumberland Plateau - sandstone aquifers with limited capacity to sustain public-water systems. Currently supplying $<0.1 \mathrm{Mgal} / \mathrm{d}$ to individual supply systems.

Valley and Ridge, Sequatchie Valley - Limestone aquifers can be very productive and can sustain large withdrawals ( $3-5 \mathrm{Mgal} / \mathrm{d})$ for public-water systems. Supplies can be limited depending on local conditions.

Blue Ridge - Variable conditions. Fractured rock in the uplands typically sustain small water systems $(<0.25 \mathrm{MGal} / \mathrm{d})$. Limestone aquifers in the coves and valleys can sustain large systems $(3-5 \mathrm{Mgal} / \mathrm{d})$.

Figure and groundwater information from $\mathrm{TNH} 2 \mathrm{O}, 2018$

Figure 10. Distribution of public water systems withdrawing groundwater from the regional aquifers in Tennessee, 2015. 


\section{Selected References}

Bradley, M.W., 1984, Ground water in the Dickson area of the western Highland Rim of Tennessee: U.S. Geological Survey Water-Resources Investigations Report 82-4088, 42 p., https://pubs.usgs.gov/wri/wri824088/.

Bradley, M., Carmichael, J., Johnson, G., and Miller, B., 2018, Groundwater/surface-water interaction along the western edge of the Blue Ridge province, Blount and Sevier Counties, Tennessee: Journal of the Tennessee Academy of Science, v. 93, no. 1-2, p. 20.

Bradley, M.W., and Hileman, G.E., 2006, Sinkhole flooding in Murfreesboro, Rutherford County, Tennessee, 2001-02: U.S. Geological Survey Scientific Investigations Report 2005-5281, 38 p., https://pubs.er.usgs.gov/publication/sir20055281.

Bradley, M.W., and Hollyday, E.F., 1985, Summary of Tennessee ground-water resources, in National Water Summary 1984-Hydrologic events, selected water-quality trends, and ground-water resources: U.S. Geological Survey Water-Supply Paper 2275, p. 391-396.

Bradley, M., and Parris, T., 2014, Geochemistry of paleokarst aquifers of the Knox Group in Tennessee and Kentucky, in Kuniansky, E.L., and Spangler, L.E., eds., U.S. Geological Survey Karst Interest Group Proceedings, Carlsbad, New Mexico, April 29-May 2, 2014: U.S. Geological Survey Scientific Investigations Report 2014-5035, p. 121-124, http://dx.doi.org/10.3133/sir20145035.

Brahana, J.V., and Bradley, M.W., 1985a, Preliminary delineation and description of the regional aquifers of Tennessee-The Central Basin aquifer system: U.S. Geological Survey Water-Resources Investigations Report 82-4002, 35 p., https:/pubs.usgs.gov/wri/wrir82-4002/.

Brahana, J.V., and Bradley, M.W., 1985b, Delineation and description of the regional aquifers of Tennessee-The Knox aquifer in central and west Tennessee: U.S. Geological Survey Water-Resources Investigations Report 83-4012, 32 p., https://pubs.usgs.gov/wri/wri834012/.

Brahana, J.V., and Bradley, M.W., 1986, Preliminary delineation and description of the regional aquifers of Tennessee-Highland Rim aquifer system: U.S. Geological Survey Water-Resources Investigations Report 82-4054, 38 p., https://pubs.usgs.gov/wri/wri824054/.
Brahana, J.V., Macy, Jo Ann, Mulderink, D., and Zemo, D., 1986, Preliminary delineation and description of the regional aquifers of Tennessee-Cumberland Plateau aquifer system: U.S. Geological Survey Open-File Report 82-338, 24 p., https://pubs.usgs.gov/wri/wrir82-338/ pdf/wrir_82-338_a.pdf.

Brahana, J.V., Mulderink, D., Macy, Jo Ann, and Bradley, M.W, 1986, Preliminary delineation and description of the regional aquifers of Tennessee-The East Tennessee aquifer system: U.S. Geological Survey Water-Resources Investigations Report 82-4091, 30 p., https://pubs.usgs.gov/wri/wri824091/.

Burchett, C.R., and Hollyday, E.F., 1974, Tennessee's newest aquifer [abs.]: Geological Society of America Abstracts with Programs, Annual Meeting, v. 6, no. 1, p. 338.

Crawford, N.C., 1987, The karst hydrogeology of the Cumberland Plateau Escarpment of Tennessee: Subterranean stream invasion, conduit cavern development, and slope retreat in the Lost Creek Cove area, White County, Tennessee: Tennessee Department of Environment and Conservation, Division of Geology, Report of Investigations no. 44, pt. 1, 43 p.

Hatcher, R.D., and Thomas, W.A., 1989, Southern Appalachian windows - Comparison of styles, scales, geometry and detachment levels of thrust faults in the foreland and internides of a thrust-dominated orogeny, Atlanta, Georgia to Winston-Salem, North Carolina: American Geophysical Union, Field Trip Guidebook, June 28-July 8, 1989, ISBN 0-87590-616-B, 93 p.

Hollyday, E.F., and Hileman, G.E., 1996, Hydrogeologic terranes and potential yield of water to wells in the Valley and Ridge physiographic province in the eastern and southeastern United States: U.S. Geological Survey Professional Paper 1422-C, 30 p., https://pubs.er.usgs.gov/publication/pp1422C.

Kemmerly, P.R., 1982, Spatial analysis of a karst depression population-Clues to genesis: Geological Society of America Bulletin, v. 93, no. 11, p. 1078-1086, https://doi.org/10.1130/0016-7606(1982)93<1078:SAOAK $\mathrm{D}>2.0 . \mathrm{CO} ; 2$.

Law, G.S., 2002, Duration and frequency analysis of lowland flooding in western Murfreesboro, Rutherford County, Tennessee, 1998-2000: U.S. Geological Survey Water-Resources Investigations Report 2002-4266, 30 p., https://pubs.er.usgs.gov/publication/wri024266. 
Lindsey, B.D., Katz, B.G., Berndt, M.P., Ardis, A.F., and Skach, K.A., 2009, Relations between sinkhole density and anthropogenic contaminants in selected carbonate aquifers in the eastern United States: Environmental Earth Sciences, v. 60, no. 5, p. 1073-1090, https://pubs.er.usgs.gov/publication/70003741.

Marcher, M.V., Bingham R.H., and Lounsbury, R.E., 1964, Ground-water geology of the Dickson, Lawrenceburg, and Waverly areas in the western Highland Rim, Tennessee: U.S. Geological Survey Water-Supply Paper 1764, 50 p., https://pubs.er.usgs.gov/publication/wsp1764.

Miller, B.V., Bradley, M.W., and Brown, T.L., 2018, Karst hydrogeology of Tuckaleechee Cove and the western Great Smoky Mountains, Tennessee and North Carolina, USA, in Engel, A.S., and Hatcher, R.D., Jr., eds., Geology at every scale-Field excursions for the 2018 GSA Southeastern Section meeting, Knoxville, Tennessee: Geological Society of America Field Guide 50, p. 49-60, https://doi.org/10.1130/2018.0050(03).

Miller, R.A., 1974, The geologic history of Tennessee: Tennessee Division of Geology, Bulletin 74, 63 p.

Moore, H.L., 1988, A roadside guide to the geology of the Great Smoky Mountains National Park: University of Tennessee Press, 192 p.

Newcome, Roy, Jr., and Smith, Ollie, Jr., 1962, Geology and ground-water resources of the Knox Dolomite in Middle Tennessee: Tennessee Division of Water Resources, Water Resources Series No. 4, 43 p.

Nichols, L.E., and Bulow, F.L., 1973, Effects of acid mine drainage on the stream ecosystem of the East Fork of the Obey River, Tennessee: Journal of the Tennessee Academy of Science, v. 48, no. 1, p. 30-39.

Niemiller, M.L., Zigler, K.S., Stephen, C.D.R., Carter, E.T., Paterson, A.T., Taylor, S.J., and Engel, A.S., 2016, Vertebrate fauna in caves of eastern Tennessee within the Appalachians karst region, USA: National Speleological Society Journal of Cave and Karst Studies, v. 78, no. 1, p. 1-24, https://caves.org/pub/journal/PDF/v78/cave-7801-1.pdf.
Nolfi, D.C., 2011, National Park Service cave and karst resources management case study_Great Smoky Mountains National Park: Bowling Green, Department of Geography and Geology, Western Kentucky University, Master's thesis, 269 p., http://digitalcommons.wku.edu/cgi/ viewcontent. cgi?article $=2056 \&$ context $=$ theses .

O’Bara, C.J., and Estes, R.D., 1985, Acid mine drainage contaminates groundwater of a Tennessee watershed: Environmental Geology and Water Science, v. 7, p. 159-161.

Reesman, A.L., and Godfrey, A.E., 1972, Chemical erosion and denudation rates in Middle Tennessee: Tennessee Department of Conservation, Division of Water Resources, Research Series No. 4, 40 p.

Seal, R.R., Cooper, B.J., and Craig, J.R., 1985, Anisotropic sphalerite of the Elmwood-Gordonsville deposits, Tennessee: Canadian Mineralogist, v. 23, p. 83-88.

Sutherland, Chuck, 2016, Tennessee caves, 2016: Data from Tennessee Cave Survey, accessed February 9, 2020, at https://www.flickr.com/photos/chucksutherland/ 29729034975/in/album-72157712605454427/.

Tennessee Cave Survey (TCS), 2020, Cave records and data tables: Tennessee Cave Survey web page, accessed February 5, 2020, at http://www.subworks.com/tcs/.

TN H2O, 2018, Tennessee's roadmap to securing the future of our water resources: Tennessee Department of Environment and Conservation, Groundwater Working Group, https://www.tn.gov/environment/program-areas/wr-waterresources/tnh2o/the-2018-tn-h2o-plan.html.

U.S. Geological Survey, 2020, National Water Information System-Water use data for Tennessee: U.S. Geological Survey web page, accessed June 24, 2020, at https://waterdata.usgs.gov/tn/nwis/wu.

Wolfe, W.J., Haugh, C.J., Webbers, A., and Diehl, T.H., 1997, Preliminary conceptual models of the occurrence, fate, and transport of chlorinated solvents in karst regions of Tennessee: U.S. Geological Survey Water-Resources Investigations Report 97-4097, $80 \mathrm{p}$. 


\title{
A Structural Explanation for the Relatively Large Mapped Length of Snail Shell Cave, Central Tennessee
}

\author{
By Mark Abolins ${ }^{1}$ and Albert Ogden ${ }^{2}$ \\ 'Middle Tennessee State University, Geosciences Department, Murfreesboro, TN 37132. \\ ${ }^{2}$ Emeritus, Middle Tennessee State University, Geosciences Department, Murfreesboro, TN 37132. \\ (Email: Mark.Abolins@mtsu.edu)
}

\begin{abstract}
At greater than 14.5 kilometers $(\mathrm{km})$ in length, Snail Shell Cave is the westernmost of the eight caves having the largest mapped lengths in Tennessee. The western and central parts of the cave mostly trend 270-280 degrees and compose greater than 35 percent of the cave's mapped length. A structure surface (digital elevation model of a geologic contact) of the Upper Ordovician Lebanon-Carters contact shows that the western and central parts of the cave are within 378 plus or minus 9 meters $(\mathrm{m})$ of, and are parallel to, the crest of a gentle doubly plunging 4.8-kilometer-long anticline trending about 282 degrees, associated with about $18 \mathrm{~m}$ of
\end{abstract}

structural relief, and occupying an area of $6.17 \mathrm{~km}^{2}$. The surface was constructed using an Arc-GIS natural neighbor interpolation of the elevations of the Lebanon-Carters and Upper Ordovician Ridley-Lebanon contacts. Elevations are from a LiDAR-based digital elevation model having a nominal point spacing of $1.5 \mathrm{~m}$ and a vertical accuracy better than plus or minus 9 centimeters. In Tennessee, similar relations between gentle structural highs and groundwater conduits exist within Mississippian limestones at locations 105-145 km to the east. On geologic maps, those locations are within about $11 \mathrm{~km}$ of macroscale faults, but Snail Shell Cave is about 95 $\mathrm{km}$ west of the nearest macroscale Appalachian foreland fault mapped at the surface. 


\title{
Karst Hydrogeology at the Tennessee Valley Authority Gallatin Fossil Plant and Impacts on the Fate and Transport of Coal Combustion Residuals
}

\author{
By Chris Groves' and Mark Quarles²
}

\begin{abstract}
${ }^{1}$ Western Kentucky University, Department of Earth, Environmental, and Atmospheric Sciences, Crawford Hydrology Laboratory, Bowling Green, KY 42101. ${ }^{2}$ BBJ Group, 1616 Westgate Circle, Brentwood, TN 37027.

(Email: chris.groves@wku.edu)
\end{abstract}

\begin{abstract}
Coal combustion residuals (CCR) are one of the country's largest sources of industrial waste, and leachate from these can contain hazardous substances including mercury, arsenic, and selenium. The U.S. Environmental Protection Agency's 2015 CCR Rule contains guidance pertaining to CCR management and monitoring of groundwater at existing facilities. Unlined CCR storage in karst systems can allow transport of CCR leachate into groundwater and surface water.

The purpose of this research has been to evaluate the hydrogeology of Odom's Bend, Tennessee, where coal ash generated by the Tennessee Valley Authority (TVA) Gallatin Steam Plant, built on Ordovician limestones of Tennessee's Central Basin, has been deposited in unlined surface impoundments or ponds on approximately 140 hectares of the former valley of Sinking Creek. The TVA planned to close the ponds "in-place" by constructing a cap over the ponds and allowing the wastes to remain in perpetuity. Although such a karst hydrogeologic evaluation would have been relatively straightforward prior to backflooding of the aquifer and adjacent Cumberland River by Old Hickory Lake, construction of the power plant and the deposition of millions of cubic meters of coal ash slurry made the investigative task of evaluating connectivity to Old Hickory Lake much more complicated. Potentiometric surface mapping shows directions of groundwater flow, and pre-ash topographic maps show sinkholes, blind valleys, and sinking streams that reflect the geometry of the karst flow system. Decades-old TVA memos describing development of the facility also provide key data
\end{abstract}

that clearly indicate that coal ash slurry and leachate have been leaking through the karst aquifer into Old Hickory Lake for more than 50 years.

After construction of an outfall dam in Sinking Creek Valley and filling with ash slurry beginning in 1970, the pond level initially rose to within about 1.3 meters of the outfall level, followed by a relatively sudden drop. A TVA memo described a "boil" in the river around the same time that presumably represented rapid flow from an unlined pond(s) to a major spring now under the lake. Historical records of the spring's location are no longer available. The pond level then failed to rise to the outfall level for the next 8.6 years, with frequent lake and pond fluctuations. Based on memos describing a CCR slurry inflow rate of 22,700 liters per minute, a mass balance calculation indicates that more than 100 billion liters of ash slurry leaked through the karst groundwater system into Old Hickory Lake before remediation of some sinkholes. In addition, at least partial "plugging" of the connection(s) caused water to rise to the outfall level in 1978, resulting in daily surface-water overflow discharge to Old Hickory Lake.

The degree of connectivity of the unlined pond(s) to the underlying karst aquifer remained undetermined for decades. Eventually, a direct connection between the ash ponds and Old Hickory Lake was proven, and in 2019, TVA settled a state lawsuit agreeing to excavate 9 million cubic meters of coal ash slurry in multiple unlined ponds (closure-by-removal) to a dry, lined landfill at the facility, rather than closing the ponds in-place. The TVA estimates the move will take about 20 years at a cost of $\$ 640$ million. Lessons learned at this site are informing decisions for the most appropriate closure methods at other karst sites. 


\title{
Karst Hydrology of the Western Great Smoky Mountains
}

\author{
By Benjamin V. Miller ${ }^{1}$ and Michael Bradley²
}

${ }^{1}$ U.S. Geological Survey, 640 Grassmere Park, Suite 100, Nashville, TN 37211.

${ }^{2}$ Emeritus, U.S. Geological Survey.

(Email: bvmiller@usgs.gov)

\begin{abstract}
The Great Smoky Mountains in Tennessee and North Carolina are a mountain range that is largely dominated by siliciclastic and metamorphic strata. Along the western portion of the mountain range are several carbonate fensters (windows) along the western edge of the Great Smoky Thrust Fault. The fensters expose Lower Ordovician Jonesboro Limestone, a sub-unit of the Knox Group, which can be slightly marbleized in areas close to the fault plane. The fensters create opportunities for allogenic recharge to occur at points along the contact of the surrounding insoluble strata with the underlying soluble carbonates, which has resulted in the development of karst flow systems. In Tuckaleechee Cove, thick carbonate exposures, chemically aggressive recharge, and high vertical relief have resulted in the formation of deep cave systems with active streams draining to springs lower in the cove. In Cades Cove, the carbonate fenster has a much lower vertical relief and is covered by colluvium, resulting in streams that sink along the contact with insoluble strata but have a much slower travel time from sink to spring. Although
\end{abstract}

the total number of caves within the study area is relatively small, the character of the karst and nature of the landscape have resulted in the formation of substantial cave systems, many exceeding 150 meters in depth and several kilometers in length. A study by the U.S. Geological Survey began in 2017 to characterize the hydrologic behavior of the karst systems through hydrologic monitoring, groundwater tracing, and seepage runs. Hydrologic monitoring equipment was installed at two in-cave sites, two major springs, along Abrams Creek in Cades Cove, and at a karst depression wetland. Groundwater tracing was conducted to determine resurgences for the cave systems, delineate spring recharge areas, and to get an approximation of karst groundwater velocities. Seepage runs along Abrams Creek and major tributaries helped to determine both the location and degree to which surface streams were sinking into the Jonesboro Limestone either at the contact with insoluble strata or as streams flowed across the carbonate fenster. Results have shown considerable differences between the karst flow systems in Tuckaleechee Cove compared to those in Cades Cove and have helped to better understand the vulnerability and uniqueness of these systems. 


\title{
Abstracts-Agriculture and Karst Issues
}

\section{Communicating Karst Science-Lessons Learned From Hydrogeologic Characterization of a Mantled Karst Near a Concentrated Animal Feeding Operation in the Southern Ozarks, Northern Arkansas}

\author{
By Van Brahana, ${ }^{1}$ Phil Hays, ${ }^{2,3}$ and Joshua Blackstock ${ }^{3}$ \\ ${ }^{1}$ Emeritus, U.S. Geological Survey. \\ ${ }^{1}$ Emeritus, University of Arkansas, Department of Geosciences, 222 Gearhart Hall, Fayetteville, AR 72701. \\ ${ }^{2}$ U.S. Geological Survey, 700 W. Research Blvd., Fayetteville, AR 72701. \\ ${ }^{3}$ University of Arkansas, Department of Geosciences, 216 Gearhart Hall, Fayetteville, AR 72701. \\ (Email: brahana@uark.edu)
}

\section{Abstract}

With the recent $\$ 6.2$ million buyout of C\&H Hog Farm, a concentrated animal feeding operation (CAFO) in the Big Creek basin within the Buffalo National River watershed, multiple state, non-profit, and private entities in Arkansas reached a resolution with the CAFO owners to terminate a contentious environmental action. Initial permitting of this facility lacked consideration and discussion of the karst and the hydrogeology, which was known for more than a century. A group of volunteers with extensive professional experience, including karst hydrogeology, initiated a research project to address this critical omission and followed with an intensive communication effort to share their findings with the general public. Enhanced understanding of karst was facilitated by collaboration with an investigative journalist and a diverse group of stakeholders, both in the study area and throughout the state. This diverse group of citizens created a coordinated program of information and education using web pages, public presentations, and training involving question and answer sessions. This created a statewide network that allowed the general public to become reasonably proficient in basic concepts of karst hydrogeology as it relates to the CAFO. This study reiterates a clear need for scientists to engage with all stakeholders and to build communication links with the objective of enhancing scientific understanding and providing clarity to the real costs and benefits of undertaking potentially risky projects.

\section{Introduction}

The recent (2019) \$6.2 million buyout of C\&H Hog Farm by a consortium of state, non-profit, and private entities in Arkansas enabled a resolution to be reached with the owner of a concentrated animal feeding operation (CAFO) to terminate a 7-year operation that was perceived as risky. The CAFO was located about 10 kilometers upstream from one of the most popular tourist attractions in the state, the Buffalo National River (BNR) (Mike Masterson, Arkansas Democrat Gazette, oral commun., 2015).

Selected details of the start-up of the CAFO were introduced to the Karst Interest Group (KIG) 7 years ago (Brahana and others, 2014), including omissions and scientific flaws of the permitting process by state regulators as documented by Hovis (2014). Specifically, initial permitting documents did not include any assessment of groundwater, karst, or characterization of pre-CAFO water quality for surface water and groundwater, essential components of the hydrologic budget of the area. All of these topics have implications for water quality in the BNR.

In the study area (fig. 1), the Boone Formation is the most karstified geologic unit. Where the Boone consists of pure limestone, such as in its uppermost and lowermost units, sinkholes exist, although few have more than a 3-square-meter open-void footprint (fig. 2). Where chert is the dominant lithology in the middle of the formation, karst dissolution generally is confined and parallel to (below and above) the chert layers, and dissolution conduits tend to be small. This interval of thin, recurring limestone and chert layers, called couplets, results in a unique segregation of groundwater flow (fig. 3), creating complexity at intermediate and larger scales. 


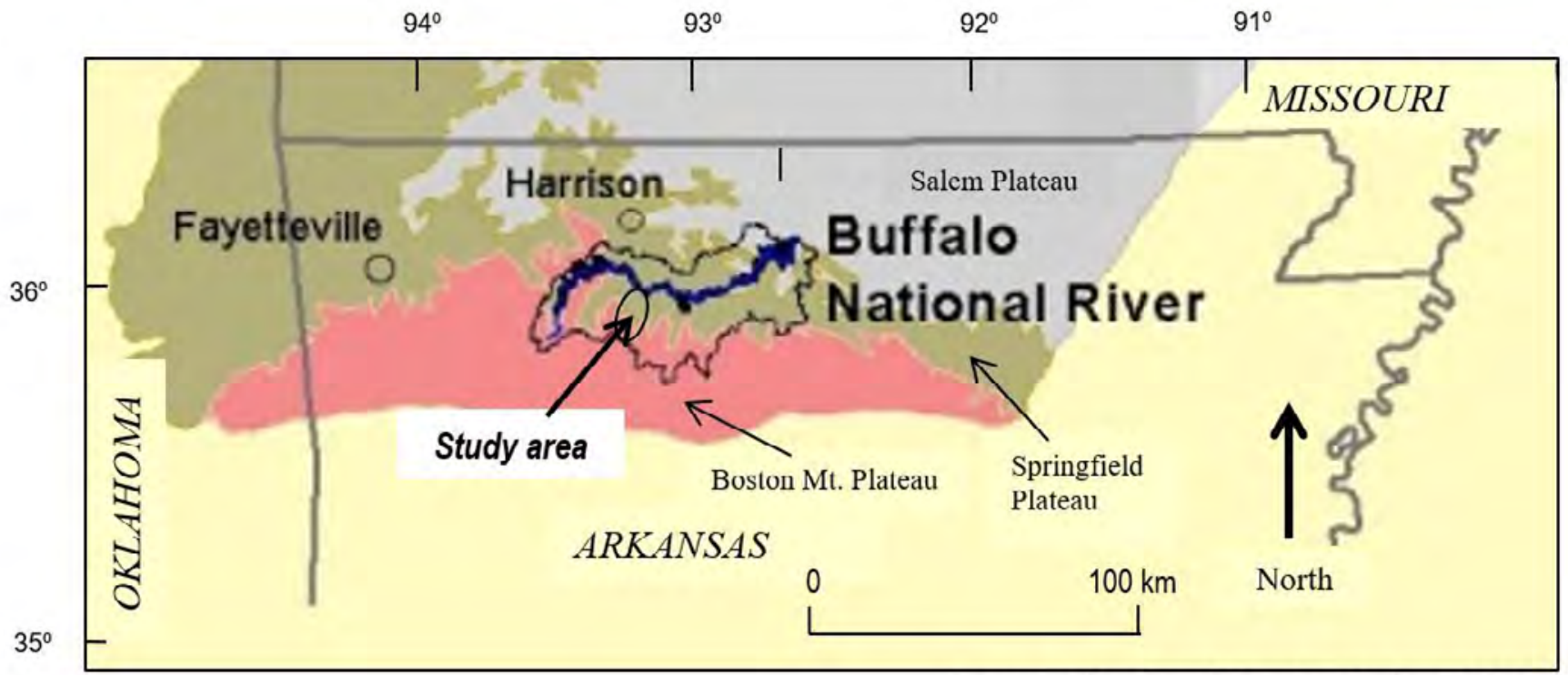

Figure modified from Adamski and others, 1995

Figure 1. Generalized study area within regions of the Ozark Plateaus in northern Arkansas, including the drainage basin of the Buffalo National River, which is managed by the National Park Service. The karst area discussed in this study is restricted to the Boone Formation on the Springfield Plateau (olive green area) in the area of Big Creek and contiguous surface-water basins (black ellipse) draining into the Buffalo National River.

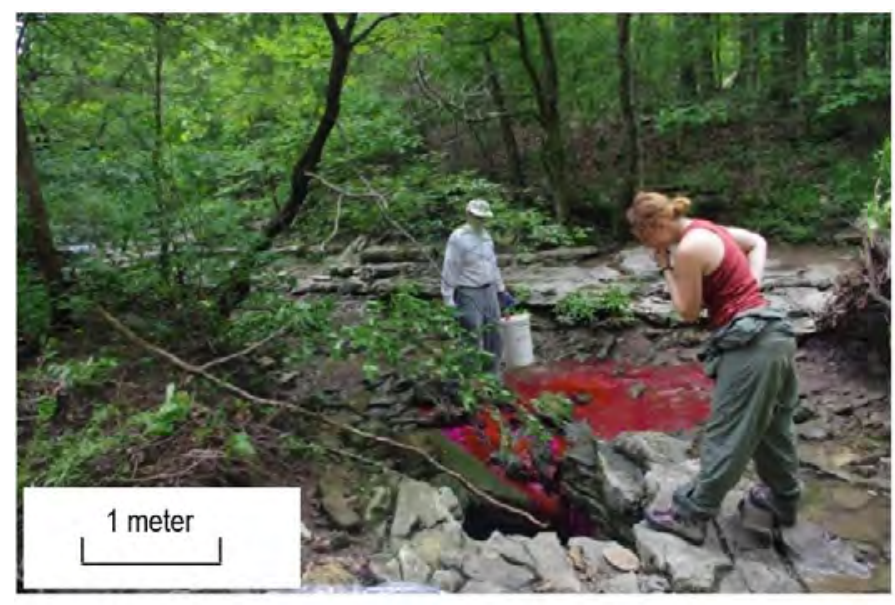

Photo by L.C. Bitting, Karst Hydrogeology of the Buffalo National River, 2014

Figure 2. Sinkhole in the upper pure limestone of the Boone Formation along Dry Creek, just upstream of the waste-spreading fields of the concentrated animal feeding operation along its southern boundary. Typical sinkhole areas range from 1 to 3 square meters.

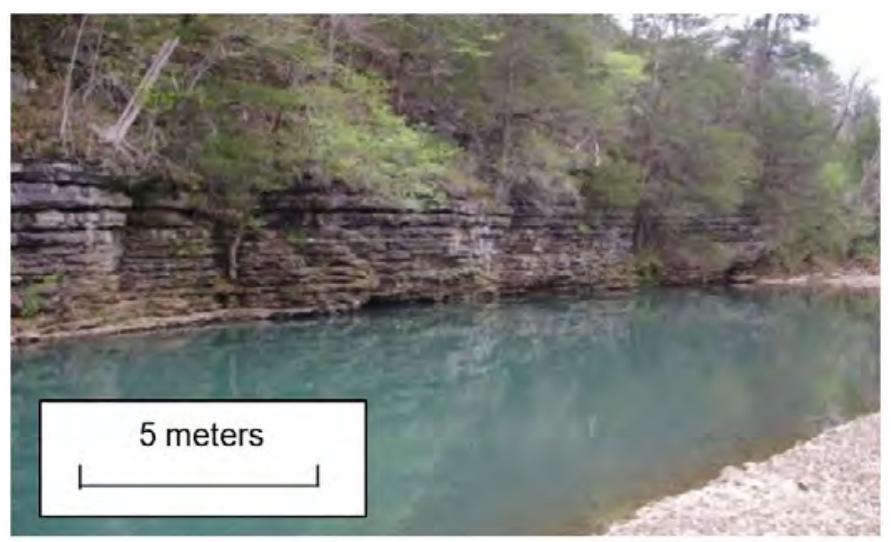

Photo by V. Brahana, University of Arkansas, 2015

Figure 3. Development of karst in the limestone within the interval of limestone/chert couplets on Big Creek, about 2 kilometers downstream from the concentrated animal feeding operation. The dark, nearly horizontal layers in the outcrop above the stream are zones along which the limestone has been dissolved; chert in the photo is light grey. 
These couplets are present throughout most of the middle part of the Boone, and their occurrence and hydrogeologic role is described in an accompanying paper in this KIG proceedings (Brahana and Manger, 2021).

The CAFO occurs in the Big Creek basin, flowing directly into the BNR with gaining and losing reaches along its channel. It is an area of mantled karst, whereby visible karst features typically are covered and thus obscured by, an insoluble residue of primarily clay and chert from chemical weathering. Nonetheless, groundwater flow throughout the outcrop area of the Boone Formation in northern Arkansas is characterized as distinctly karst (Giles, 1935; Funkhouser and others, 1999; Braden and Ausbrooks, 2003; Hobza and others, 2005; Brion and others, 2010).

Karst is considered vulnerable to various anthropogenic land-use activities, owing to its fast flow and generally minimal attenuation of contaminants, and it requires hydrogeologic characterization so that risk can be accurately communicated to the general public (Quinlan, 1989). Another need to facilitate an understanding of karst involves educating the public about basic concepts of groundwater movement through these types of rocks. To accomplish these needs, volunteers, mostly retirees and students from the U.S. Geological Survey (USGS), the University of Arkansas (U of A), Ouachita Baptist University, and former employees from the agriculture industry joined together to form the Karst Hydrogeology of the BNR (KHBNR) team to conduct a hydrogeologic characterization of the study area near the CAFO. A separate group, the U of A Big Creek Research and Extension Team (BCRET), focused on surface-water and soils research. This group consisted of U of A Division of Agriculture professors and extension agents, and was funded by the governor of Arkansas; two USGS hydrologists also assisted this group.

The main concern of most neighbors near the CAFO and environmental stakeholders was that Big Creek and the BNR would become contaminated from nutrient and microbial loading (https://www.ualrpublicradio.org/post/petitionsregulate-hog-farms-buffalo-river-advance). Environmental problems associated with CAFOs are well known in most places where they have been constructed (Imhoff, 2010), and CAFOs on karst lie at the intersection of diverse disciplines. This study focuses on communicating the science of karst hydrogeology to stakeholders and the general public to achieve scientific literacy. The scope of the paper limits consideration to the karst of the Boone Formation in Big Creek and contiguous surface-water basins in the area of the BNR (fig. 1).

\section{Brief Overview of Selected CAFO Events}

The initial permitting of the CAFO occurred in 2012, with minimal notification of the request to operate. Details of the original permitting have been discussed previously, and the interested reader is referred to the documentation and related web pages cited in Hovis (2014) and Brahana and others (2014). Initial funding for scientific assessment of the project allowed creation of the BCRET by the former governor.

In 2014, a legal determination by the U.S. District Judge for the Eastern District of Arkansas required two federal agencies who guaranteed the loans to the CAFO, the Small Business Administration (SBA) and the U.S. Department of Agriculture (USDA) Farm Service Agency (FSA) take "a closer look" at the Notice of Intent (Marshall, 2014). Among other items, the lawsuit required new consulting reports to be produced by consultants for each agency. The Notice of Intent, and the resulting consulting reports prepared in 2014 for the SBA and the FSA failed to recognize or disclose the fact that the CAFO and its spreading fields were sited on karst. This omission highlighted the need to address the general lack of understanding of karst hydrogeology by the general public and all the stakeholders.

The timeline from 2014 to 2018 involved active scientific study by the BCRET and KHBNR team, including publication and presentation of results to selected stakeholders, and multiple legal and regulatory skirmishes. The primary result after intensive activity was that the Arkansas Department of Environmental Quality (ADEQ) denied the permit renewal for the CAFO in 2018. In 2019, the decision to close this CAFO was made by the current governor, after receiving more than 20,000 letters, most all of which favored closing the CAFO.

\section{Communicating Results of Selected Karst Studies for Stakeholder Education}

Three studies that helped convince stakeholders of the hydrogeologic connection between the CAFO and the BNR included (1) establishing the physical attributes of karst hydrogeology that operate within Big Creek basin, including that the area was underlain by karst; (2) showing there was a close temporal relation among precipitation, surface water, and groundwater, thereby justifying use of dug wells for dye injection; and (3) documenting dye-tracing results from locations within the area of the CAFO operation to springs that flowed into the BNR.

Although groundwater quality was another major focus of the study, data were presented previously in Brahana and others (2016). Big Creek initially was not determined to be an impaired stream until several years after the CAFO started operation (https://www.arkansasonline.com/news/2018/jul/ 27/14-3-mile-section-of-buffalo-river-big-/). Since then, Big Creek has been classified as impaired by the ADEQ. Also, during the summers of 2018 and 2019, widespread algal growth occurred in the BNR in swift-flowing sections of the river (https://www.nps.gov/buff/learn/news/buffaloriver-algae-update.htm) (fig. 4). These previously unaffected areas of the river provided a strong visual impact and played an influential role in public perception that nutrients had increased (https://www.arkansasonline.com/news/2019/feb/ 24/take-action-to-save-the-river-20190224/), although the 


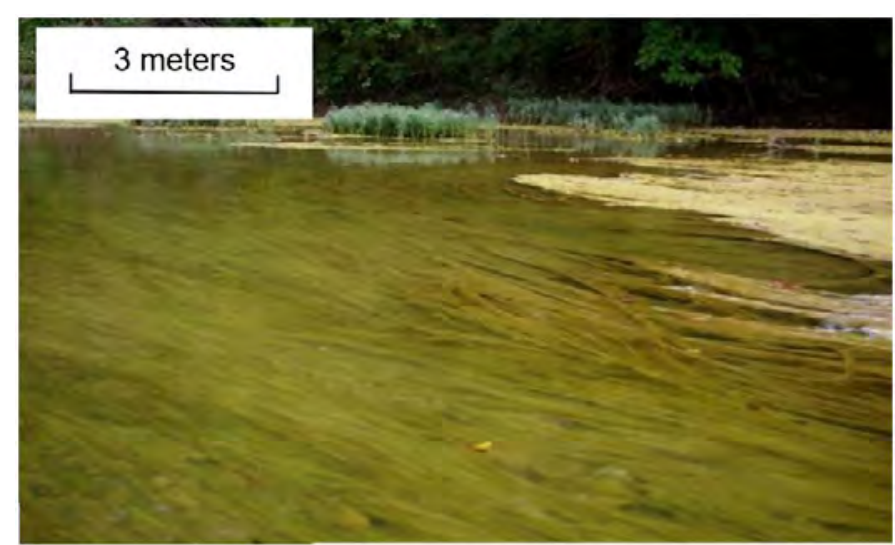

Photo by L.C. Bitting, Karst Hydrogeology of the Buffalo National River, 2018

Figure 4. Growth of algae in a flowing portion of the Buffalo National River during the summers of 2018 and 2019 played a large role in public perception that nutrient transport from the concentrated animal feeding operation was moving into the springs and streams that drain to the river.

nutrient source determination has not been firmly established (https://dl.sciencesocieties.org/publications/ael/abstracts/2/1/ 170027; https://scholarworks.uark.edu/etd/3400/).

\section{Informing the Public That Mantled Karst Underlies Big Creek Basin}

Although the realization that karst existed in the study area had been known to geologists and hydrologists for almost a century (Croneis, 1930; Giles, 1935; Aley, 1988; Imes and Emmitt, 1994; Mott and others, 2000; Braden and Ausbrooks, 2003; Fields and Halihan, 2015), this information had not been effectively transferred to most of the general public. The subtle appearance of the mantled karst required an explanation of why the area didn't have "karst topography."

The involvement of investigative journalist Mike Masterson of the Arkansas Democrat Gazette early in the project resulted in communication of hydrogeologic and karst concepts to a wide audience of citizens through several opinion pieces. His lifelong experiences and love of the river gave him a strong preservation bias, but the fact-verification requirements of his newspaper carried a sense of truth and accuracy in what he wrote. His willingness to understand complex concepts and share them in clear, non-scientific language allowed his interpretation of complex karst behavior to be framed in non-technical terms for his audience. In addition to introducing new terms, he explained basic physics and chemistry processes as understandable concepts.

During approximately the same time interval, the KHBNR team gave technical talks in major towns and cities in the region. These included showing images of karst features in the area, interpretive diagrams to further explain the presence and significance of karst, and shared answers to numerous questions. All was reiterated and reinforced on websites of the Buffalo River Watershed Alliance, the Ozark Society, the Arkansas Canoe Club, and other groups as an important part of the communication effort. In addition, KIG reports and peer-reviewed articles (Brahana and others, 2014; Murdoch and others, 2016; Brahana and others, 2016; Brahana and others, 2017) were provided to stakeholders by KHBNR professional colleagues, although these were typically reformatted into non-scientific terminology as educational talks to the public. What started as a generally uninformed but interested audience became knowledgeable and conversant in karst terminology and concepts.

\section{Showing the Close Relation Among Precipitation, Surface Water, and Groundwater}

Because the land surface in the study area is mantled with regolith, it does not allow easy visualization of enhanced pathways for groundwater movement to the subsurface. The method the KHBNR team chose to overcome this uncertainty was to show the timing of rainfall (cause) and the timing of the rapid response of surface water and groundwater (response), and then to compare the response to non-karst settings. This relation was essential in order to explain why some of the dye injection sites included dug wells. Agricultural groups were particularly critical of using dug wells, claiming that dye injection should be on the land surface where the hog waste was applied and not into groundwater. Insofar as the KHBNR team did not have personal permissions to be on the waste-spreading fields, and the fact that they had a limited budget for dye, it was imperative to justify using dug wells.

A plot of nearly coincident timing of surface and groundwater levels in response to precipitation (fig. 5) shows a close interrelation, and later dye tracing provided documented point-to-point travel. Rainfall timing and intensity were recorded digitally by tipping-bucket rain gages, and river stage and water levels in wells were recorded digitally on transducers. Stage and water levels were programmed to be measured at 5-minute intervals, and the resulting data were compiled for May 2015 (fig. 5). Results of the close relation between surface water and groundwater provided a convincing argument for rapid karst recharge and allowed further discussion of the attributes of karst aquifers to be thoroughly studied and better understood.

These new insights obtained from continuously monitored well sites arrived serendipitously from examination of the water-level data in dug wells. The rapid decline of water levels (recession) in well BS-36 reflected different slopes for four multiple couplets (fig. 6). Couplet designation was assigned by the breaks in slope of the recession curves, highlighted by the red dashes (fig. 6). These records also allowed for determination of the vertical extent of each couplet. 


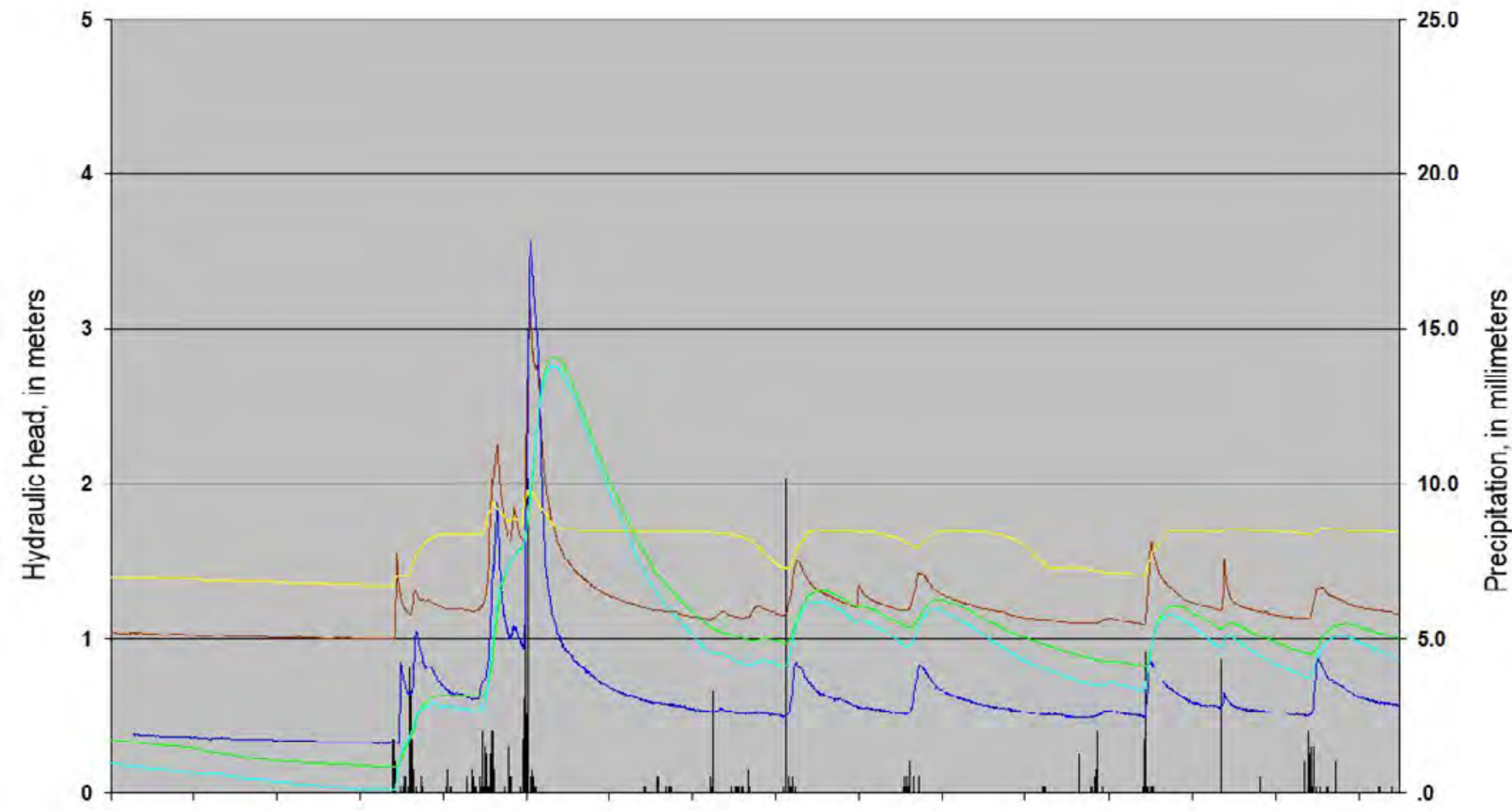

Time, from May 1, 2015, through May 31, 2015

Figure modified from Murdoch and others, 2016

Figure 5. Continuous records of precipitation (black vertical lines), surface-water stage in Big Creek near Mt. Judea (brown) and in Left Fork Big Creek near Vendor (blue), and groundwater levels in dug wells BS-36 (yellow), BS-39 (turquoise), and in drilled alluvial well BS-40 (green), showing their close temporal relation. Well BS-40 is outside the area shown on figure 7.

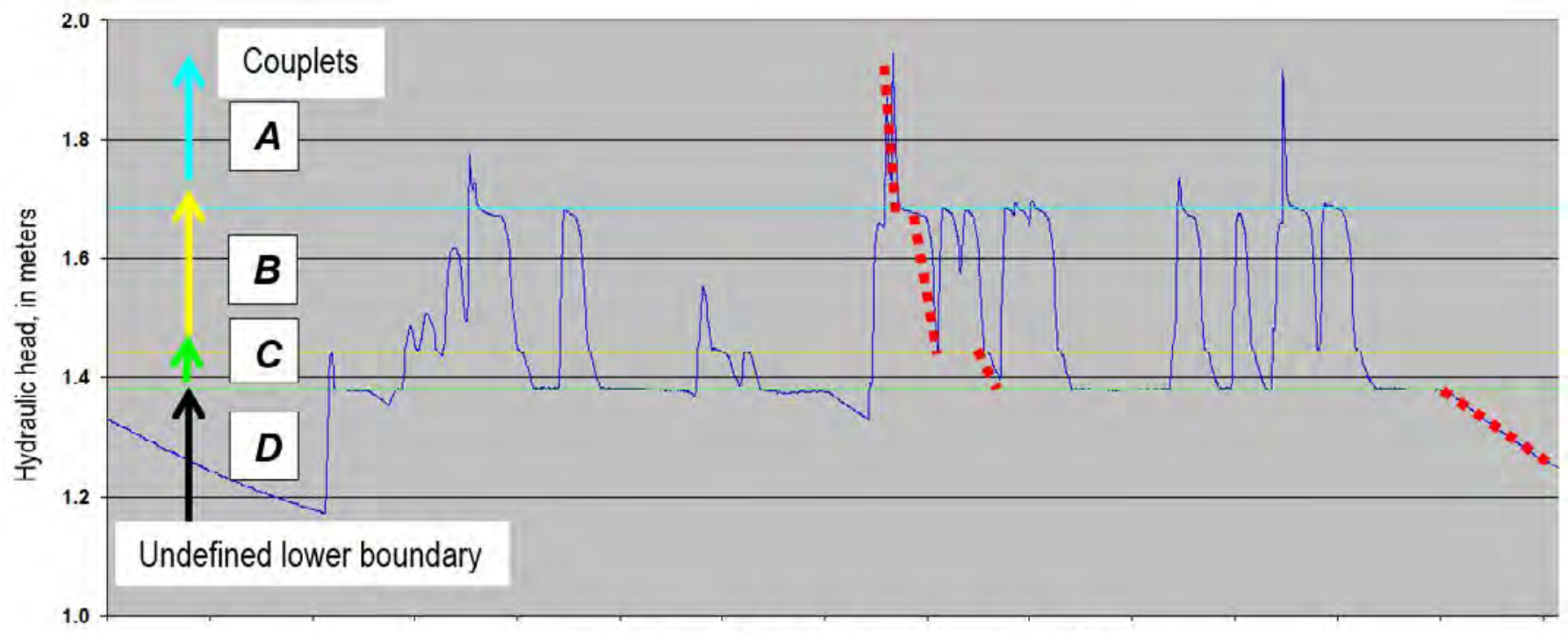

Time, from January 23, 2015, through August 8, 2015

Figure 6. Continuous groundwater level (blue) in dug well BS-36, expanded to show the effects of the limestone/chert couplets A-D on water-level recharge and recession (red dashes) in the couplet part of the Boone Formation. Well BS-36 is surrounded by fields receiving waste from the concentrated animal feeding operation and was the site of an eosin dye injection that resulted in radial flow under high-recharge conditions (see figure 7) as well as flow from couplet A. Couplet $D$ did not show any lateral dye movement to the springs during a second injection from this site conducted during low water-level conditions (drought) following the period of record shown above. 
The KHBNR team explained water-level recession in the well with a conceptual model. Karst flow was perched on top of successive chert layers of different couplets. Slight variations in recession slopes represented slightly different permeability as the conduits in successively lower limestone intervals were dewatered (fig. 6). The flat or gently sloping water levels represent short-term perching on top of the chert couplets. The slope of recession in each couplet is nearly identical for different recharge events. Although figure 6 highlights only one recession event for each couplet, other events in the same couplet show the same recession slope.

The generally long-term stability in water level at the top of couplet D (slightly below a head value of 1.4 meters [m] in the well) is consistent with an effective perching layer, below which the limestone allows very slow lateral movement of water. In addition, the utilization of well BS-36 for both high and low groundwater levels provided significantly different dye-tracing results (see discussion in the next section of this paper). These results were not known previously and are not necessarily easy to understand, especially by inexperienced karst students. However, with diagrams and annotated conceptual models, the KHBNR team determined that they were able to introduce concepts that provided a modicum of understanding.

\section{Documenting Groundwater Flow Velocity and Direction With Dye From the CAFO to the Buffalo National River}

Dye tracing is an essential tool of karst hydrogeology to determine point-to-point connections of flowing groundwater, and it can provide visually stunning results, in addition to scientifically irrefutable documentation if the trace is conducted properly. KHBNR personnel injected three different non-toxic dyes (fluorescein, rhodamine WT, and eosin) at four sites during five tests at different times and under different flow conditions in the area of the CAFO. The dye tests yielded additional unexpected results as well as traditionally expected flow paths (fig. 7).

Fluorescein dye injected into well BS-39 appeared in subaqueous springs in Big Creek, resulting in a straight line point-to-point velocity of slightly less than 700 meters per day $(\mathrm{m} / \mathrm{d})$. This is consistent for karst groundwater velocities elsewhere, reflecting rapid flow through the epikarst. The surface of the water in well BS-39 was visible from land surface and indicated groundwater in the epikarst. Direct recharge to the aquifer is an essential attribute of an injection point for a meaningful trace so that the dye will move rapidly to natural discharge points and not be ponded at the point of injection (Quinlan, 1989). The location of dug well BS-39 (fig. 7) provided a fortuitous location for injection, located only about $15 \mathrm{~m}$ from the east boundary of the CAFO. Construction of dug wells was known to many of the stakeholders who grew up in rural Arkansas and used them for domestic and stock water supplies. A dug well is constructed by hand digging, typically with a pick, crowbar, and shovel, to the point of refusal through regolith and into the upper part of the epikarst. Dug wells have a diameter of slightly less than $1 \mathrm{~m}$, because the person who was involved in its constuction had to fit inside. This added width provided good visibility and relatively easy access to the groundwater for water-quality sampling. The dye from the injection at well BS-39 was recovered from a bedding-plane spring (couplet) in Big Creek below stream level (subaqueous). The dye required 30 hours to resurge and was visible in the creek. The straight-line distance between the well and the spring was about $730 \mathrm{~m}$, which resulted in a conservative velocity of $600 \mathrm{~m} / \mathrm{d}$. This test established that dye and thus groundwater from the CAFO property went from the dug well to Big Creek to the BNR.

Injection site BS-71, a sinkhole in the pure-phase limestone of the upper Boone, captured most of the streamflow from Dry Creek upstream of the southern margin of the waste-spreading fields. Rhodamine WT dye was injected into the sinkhole and resurged at several springs downgradient in Dry Creek, ultimately providing visual documentation about $50 \mathrm{~m}$ upstream of the confluence of Dry Creek with Big Creek (fig. 7). The velocity of groundwater flow was estimated to be about $2,000 \mathrm{~m} / \mathrm{d}$, based on time-of-travel and using straight-line segments from the injection point to the springs for distance. The injection at BS-71 showed that flow went from the sinkhole to springs in Dry Creek, then into Big Creek, which flows into the BNR.

Injection of eosin dye into dug well BS-36 (fig. 7) occurred prior to a large precipitation event, which raised water levels to couplet A (fig. 6). The high water level resulted in recovery of the dye at numerous locations, with a near-radial pattern from the well. This well was constructed in the interval of couplets, and dye receptors placed in bedding-plane springs in Big Creek basin tested positive, as did receptors in the contiguous surface-water drainage basins of Left Fork Big Creek to the west, and Cave Creek to the east. All dye recovery sites were at springs or wells with lower water-level elevations than the injection site, and duplication of results was verified by analysis at two laboratories in Texas and Missouri (Geary Schindel, Edwards Aquifer Authority, written commun., 2016; Tom Aley, Ozark Underground Labs, written commun., 2016). Groundwater velocities from this test were calculated to be slightly less than $800 \mathrm{~m} / \mathrm{d}$ and are consistent with flow velocity in thin-bedded limestones that are part of the couplets and yielded a groundwater velocity of $600 \mathrm{~m} / \mathrm{d}$ in another test conducted previously in the study area. 


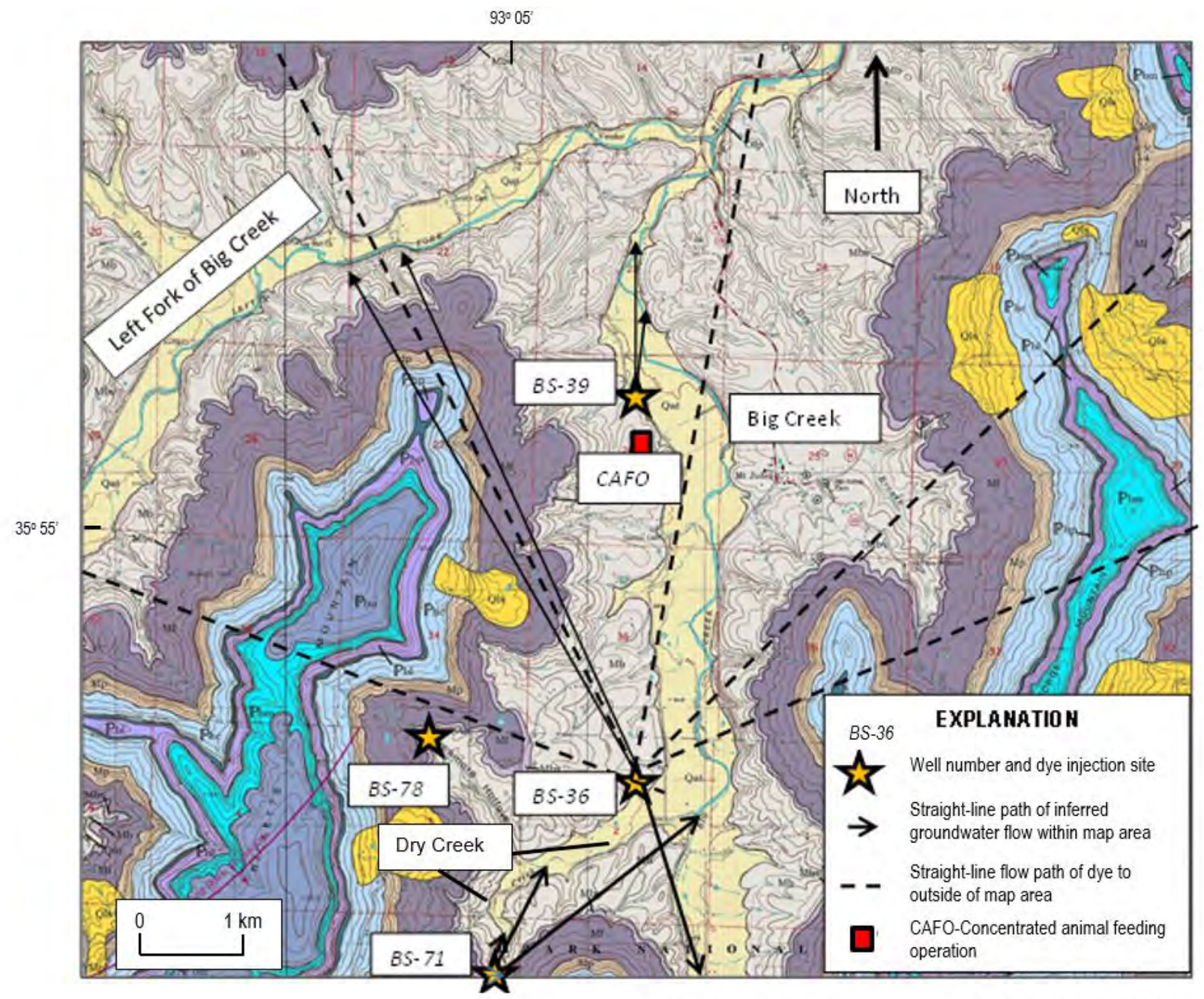

Figure modified from dye-tracing study of Brahana and others, 2017 Refer to Braden and Aisbrooks (2003) for explanation of geologic map units

Figure 7. Summary of dye tracing in Big Creek basin, reflecting the complexity of shallow groundwater flow in the Boone Formation, including radial groundwater flow from well BS-36. Not all traces to springs that flow into Big Creek are shown. 
An additional dye trace was conducted from well BS-36 several months later when water levels had declined to couplet D. None of this dye was recovered from any dye receptors in the study area, whereas dye was recoved from more than 20 locations at high water-level conditions from the same injection point. Couplet $\mathrm{D}$ is interpreted as representing a low-permeability zone similar to a leaky cistern, wherein groundwater seeps slowly from storage. Hydrogeologically, this reflects the complexity of the paleokarst in the couplets and indicates that dissolution has not been consistent nor has it occurred in all limestones of the chert-rich interval (fig. 6).

Similar to the dye trace described from well BS-36 for low water-level conditions, dye injected into ponded stream channel BS-78 (fig. 7) was never recovered from any dye receptor site in the basin. The stratigraphic interval of BS-78 is similar to the same geologic horizon as at site BS-71, suggesting that this would be a good location for another dye injection using considerably more dye and a larger area of monitoring along Dry Creek and Left Fork Big Creek.

\section{Communicating Karst Science-Lessons Learned}

An investigative journalist with the Arkansas Democrat Gazette was instrumental in communicating karst science concepts to a wide audience of citizens. Reports by the USGS Karst Interest Group (KIG) and peer-reviewed articles (Brahana and others, 2014; Murdoch and others, 2016; Brahana and others, 2016; Brahana and others, 2017) that were directed toward professional colleagues, were also important, and were typically reformatted into non-scientific terminology. The effort of simplifying major concepts of karst hydrogeology helped stakeholders with a better understanding and appreciation of the subsurface connections between the $\mathrm{CAFO}$ and the BNR, and assessing the risks these might pose. Having complementary forms of communication proved to be helpful, reinforcing learning among the stakeholders. Presentation of facts in non-technical language and visualization of complex ideas through photos and simplified diagrams and cross sections, definitely proved effective in educating the public and stakeholders.

\section{References Cited}

Adamski, J.C., Petersen, J.C., Freiwald, D.A., and Davis, J.V., 1995, Environmental and hydrologic setting of the Ozark Plateaus study unit, Arkansas, Kansas, Missouri, and Oklahoma: U.S. Geological Survey Water-Resources Investigations Report 94-4022, 69 p.
Aley, T., 1988, Complex radial flow of ground water in flat-lying residuum-mantled limestone in the Arkansas Ozarks, in Proceedings of the Second Conference on Environmental Problems in Karst Terranes and Their Solutions, Nashville, Tennessee, November 16-18, 1988: Association of Ground Water Scientists and Engineers, v. 2, p. $159-170$.

Braden, A.K., and Ausbrooks, S.M., 2003, Geologic map of the Mt. Judea quadrangle, Newton County, Arkansas: Arkansas Geological Commission, scale 1:24,000.

Brahana, V., Bitting, C., Kosic-Ficco, K., Turk, T., Murdoch, J., Thompson, B., and Quick, R., 2017, Utilizing fluorescent dyes to identify meaningful water-quality sampling locations and enhance understanding of groundwater flow near a hog CAFO on mantled karst, Buffalo National River, southern Ozarks, in Kuniansky, E.L., and Spangler, L.E., eds., U.S. Geological Survey Karst Interest Group Proceedings, San Antonio, Texas, May 16-18, 2017: U.S. Geological Survey Scientific Investigations Report 2017-5023, p. 147-160.

Brahana, V., and Manger, W., 2021, Lithologic and tectonic controls on the hydrogeology of the Boone Formation in the southern Ozarks, northern Arkansas, in Kuniansky, E.L., and Spangler, L.E., eds., U.S. Geological Survey Karst Interest Group Proceedings, October 19-20, 2021: U.S. Geological Survey Scientific Investigations Report 2020-5019, p. 98-107.

Brahana, V., Nix, J., Bitting, C., Quick, R., Murdoch, J., Roland, V., West, A., Robertson, S., Scarsdale, G., and North, V., 2014, CAFOs on karst-Meaningful data collection to adequately define environmental risk, with specific application from the southern Ozarks of northern Arkansas, in Kuniansky, E.L., and Spangler, L.E., eds., U.S. Geological Survey Karst Interest Group Proceedings, Carlsbad, New Mexico, April 29-May 2, 2014: U.S. Geological Survey Scientific Investigations Report 2014-5035, p. 87-96.

Brahana, V., Nix, J., Kuyper C., Turk, T., Usrey, F., Hodges, S., Bitting, C., Ficco, K., Pollock, E., Quick, R., Thompson, B., and Murdoch, J., 2016, Geochemical processes and controls affecting water quality of the karst area of Big Creek near Mt. Judea, Arkansas: Journal of the Arkansas Academy of Science, v. 70, p. 45-58.

Brion, G., Brye, K.R., Haggard, B.E., West, C., and Brahana, J.V., 2010, Land-use effects on water quality of a first-order stream in the Ozark Highlands, mid-southern United States: River Research and Applications, http://citeseerx.ist.psu.edu/viewdoc/download?doi=1 0.1.1.1063.1657\&rep=rep1\&type=pdf, v. 27, p. 772-790.

Croneis, C., 1930, Geology of the Arkansas Paleozoic area: Arkansas Geological Survey, Bulletin 5, 457 p. 
Fields, J., and Halihan, T., 2015, Preliminary electrical resistivity surveys of Mount Judea alluvial sites: Oklahoma State University 2 ${ }^{\text {nd }}$ Quarter 2015 Report to the Big Creek Research and Extension Team, 24 p.

Funkhouser, J.E., Little, P.R., Brahana, J.V., Kresse, T.M., Anderson, M., Formica, S., and Huetter, T., 1999, Methodology to study the effects of animal production in mantled karst aquifers of the southern Ozarks, in Palmer, A.N., Palmer, M.V., and Sasowsky, I.D., eds., Karst modeling: Karst Waters Institute, Charles Town, W.V., Special Publication 5, p. 255-258.

Giles, A.W., 1935, Boone chert: Geological Society of America Bulletin, v. 46, p. 1814-1867.

Hobza, C.M., Moffit, D.C., Goodwin, D.P., Kresse, T., Fazio, J., Brahana, J.V., and Hays, P.D., 2005, Ground-water quality near a swine waste lagoon in a mantled karst terrane in northwestern Arkansas, in Kuniansky, E.L., ed., U.S. Geological Survey Karst Interest Group Proceedings, Rapid City, South Dakota, September 12-15, 2005: U.S. Geological Survey Scientific Investigations Report 2005-5160, p. 155-162.

Hovis, S., 2014, C\&H Hog farms investigation into the permitting of a concentrated animal feeding operation in the Buffalo River watershed: Fayetteville, University of Arkansas, unpublished M.S. thesis in Civil Engineering, $90 \mathrm{p}$.

Imes, J.L, and Emmett, L.F., 1994, Geohydrology of the Ozark Plateaus aquifer system in parts of Missouri, Arkansas, Oklahoma, and Kansas: U.S. Geological Survey Professional Paper 1414-D, 127 p.
Imhoff, D., ed., 2010, CAFO-The tragedy of industrial animal factories: Foundation for Deep Ecology, in collaboration with Earth Aware Editions, Sausalito, California, $324 \mathrm{p}$.

Marshall, D.P., 2014, Case 4:13-cv-00450-DPM Document 58, United States District Court Eastern District of Arkansas, Western Division: Order of Judge Marshall in the case of several environmental groups versus the Farm Service Agency and Small Business Administration of the Federal Government regarding guarantee of loans without properly assessing the environmental impact of C\&H Hog Farms, 17 p., https://law.lclark.edu/live/files/26976-buffalo-riversj-ruling.

Mott, D.N., Hudson, M.R., and Aley, T., 2000, Hydrologic investigations reveal interbasin recharge contributes significantly to detrimental nutrient loads at Buffalo National River, Arkansas: Proceedings of Arkansas Water Resources Center Annual Conference MSC-284, Fayetteville, AR., p. 13-20.

Murdoch, J., Bitting, C., and Brahana, J.V., 2016, Characterization of the karst hydrogeology of the Boone Formation in Big Creek Valley near Mt. Judea, ArkansasDocumenting the close relation of groundwater and surface water: Environmental Earth Sciences, v. 75, 16 p., DOI 10.1007/s12665-016-5981-y.

Quinlan, J.F., 1989, Ground-water monitoring in karst terranes-Recommended protocols and implicit assumptions: U.S. Environmental Protection Agency, Research and Development, 600/X-89/050, 88 p. 


\title{
Stimulation of Plant Growth by Karst Groundwater Naturally Rich in Sulfide and Calcium
}

\author{
By Danelle Solomon, ${ }^{1}$ De'Etra Young, ${ }^{1}$ and Tom D. By|l,2 \\ ${ }^{1}$ Tennessee State University, College of Agriculture, 3500 John A Merritt Blvd, Nashville, TN 37209. \\ ${ }^{2}$ U.S. Geological Survey, 640 Grassmere Park, Suite 100, Nashville, TN 37211. \\ (Email: tdbyl@usgs.gov)
}

\begin{abstract}
Previous research has found that sterile water artificially enriched with sulfide stimulated plant biomass. The objective of this study was to determine if groundwater naturally rich in sulfide pumped from a karst aquifer located on Tennessee State University's farm stimulated plant growth. Lettuce, radish, and oat seedlings raised using water from a well containing high sulfide (65-115 milligrams per liter) were compared with seedlings raised using aerobic groundwater (with no measurable sulfide) from a well less than 200 meters away. Seeds were germinated in cellulose fibers soaked with the experimental waters and raised in a growth chamber at 20 degrees Celsius with continuous light. The oat plants raised
\end{abstract}

in the sulfur-rich water had three times more lateral roots and 18 percent greater biomass than plants raised in freshwater. Lettuce and radish plants raised in sulfide-rich water were 35 and 13 percent larger than those raised in freshwater, respectively. Plant peroxidase activity significantly increased in plants exposed to sulfide (p-value less than 0.05), giving them visibly thicker cell walls and a more compact cell. Oat plants raised in sulfide-rich water had more efficient photosynthesis capacity as compared with oat plants raised in freshwater. There was 10 percent more chlorophyll as determined by fluorescence and three times greater uptake of carbon dioxide in the oats raised in sulfide-rich water compared with those raised in aerobic groundwater. 


\title{
Abstracts-Contaminant Transport in Karst
}

\section{Identifying the Intersection of Contaminated Karst Water Sources and Plain Communities in South-Central Kentucky Using a Geographic Information System}

\author{
By Amy Hourigan, ${ }^{1}$ Patricia N. Kambesis, ${ }^{2}$ Chris Groves, ${ }^{3}$ Margaret Gripshover, ${ }^{1}$ Susan Jones, ${ }^{4}$ \\ Lee Anne Bledsoe, ${ }^{3}$ and Autumn Singer ${ }^{3}$
}

\footnotetext{
${ }^{1}$ Western Kentucky University, Department of Earth, Environmental, and Atmospheric Sciences, Bowling Green, KY 42101.

${ }^{2}$ Western Kentucky University, Applied Research and Technology Program, Center for Human GeoEnvironmental Studies, Bowling Green, KY 42101.

${ }^{3}$ Western Kentucky University, Department of Earth, Environmental, and Atmospheric Sciences, Crawford Hydrology Laboratory, Bowling Green, KY 42101. ${ }^{4}$ Western Kentucky University, School of Nursing and Allied Health, Bowling Green, KY 42101.

(Email: amy.hourigan838@topper.wku.edu)
}

\begin{abstract}
There are many "Plain" (Amish and Mennonite) communities living on south-central Kentucky's Pennyroyal Plateau, an extensive karst sinkhole plain. There is limited availability of water at the surface, and groundwater is highly vulnerable to contamination by agricultural land use. Families in many of these communities choose to live "off the grid" and for cultural reasons to forgo certain modern technologies. Some families lack treated water, either by choice or lack of infrastructure, and some families choose to live without electricity. A question presents itself: in rural areas of the karst landscape where treated municipal water is not used, where otherwise little or no water is available at the surface, and where karst springs are likely to be contaminated, how are families obtaining and transporting water, and how are they treating it?

The Department of Earth, Environmental, and Atmospheric Sciences at Western Kentucky University is developing relationships with members of these communities and has shown that there are families relying on contaminated karst groundwater, in some cases with no treatment. A year-long study found that every sample of untreated water collected from four family water supply karst springs in
\end{abstract}

Barren and Monroe Counties in south-central Kentucky tested positive for both total coliform and E. coli bacteria. The study also included a family of nine relying on an untreated karst spring, all of whom became ill with Hepatitis A in 2018. Work by the local health department and the U.S. Centers for Disease Control and Prevention also showed that the spring was contaminated with the virus.

For several springs, analysis of raw water and water treated by low-cost, onsite reverse osmosis systems - used by families with electricity - showed that even under storm conditions with elevated fecal coliform bacteria, these systems generally worked well. Settings without electricity present a much more difficult challenge.

Having shown that this problem exists, primary and secondary data are currently being compiled, and a GIS database is being developed for the ten-county Barren River Area Development District of south-central Kentucky. The goal is to identify the extent of the intersection of the region's karst water sources and those communities that use limited technology to obtain, transport, and treat water. The concept of Environmental Health Literacy is also being explored as a potential tool for understanding these physical/cultural challenges and developing templates for solutions. 


\title{
Vulnerability of Karst Groundwater to Contamination From Emerging Contaminants
}

\author{
By Barbara J. Mahler ${ }^{1}$ and MaryLynn Musgrove ${ }^{1}$
}

'U.S. Geological Survey, 1505 Ferguson Lane, Austin, TX 78754.

(Email: bjmahler@usgs.gov)

\begin{abstract}
Emerging contaminants (ECs) comprise a wide variety of chemical groups, and concern over their occurrence in groundwater resources has increased in the past few decades. The unique hydrogeologic characteristics of karst aquifers make them vulnerable to contamination, but there has been relatively little research regarding this susceptibility. Emerging contaminants occur widely in wastewater and surface water and can be transported into aquifers by natural or artificial recharge, including engineered structures and direct injection. Alternatively, ECs can be directly introduced into groundwater
\end{abstract}

as leachate draining from septic systems or landfills. Travel times and processes typical of most aquifers can attenuate ECs in groundwater to below detectable levels, but this is less likely to occur in karst aquifers as a result of thin soils, rapid travel times, and conduit flow. This presentation will review what is known about the occurrence of ECs in groundwater in general, in karst specifically, and - as a case study - in the Edwards aquifer of central Texas. It also will discuss how the natural physical characteristics of the Edwards aquifer and growing urbanization and anthropogenic activities in the region contribute to the vulnerability of the aquifer to contamination from ECs. 


\title{
Groundwater Residence Time and Vulnerability in Carbonate Principal Aquifers Across the United States
}

\author{
By MaryLynn Musgrove, ${ }^{1}$ Bryant C. Jurgens, ${ }^{2}$ Mitchell A. McAdoo, ${ }^{3}$ and Kirsten E. Faulkner ${ }^{2}$
}

\author{
${ }^{1}$ U.S. Geological Survey, 1505 Ferguson Lane, Austin, TX 78754. \\ ${ }^{2}$ U.S. Geological Survey, Placer Hall, 6000 J St., Sacramento, CA 95819. \\ ${ }^{3}$ U.S. Geological Survey, 11 Dunbar St., Charleston, WV 25301. \\ (Email: mmusgrov@usgs.gov)
}

\begin{abstract}
Groundwater residence times, or the distribution of groundwater age, informs our understanding of the susceptibility and vulnerability of groundwater to contamination. This is particularly relevant for carbonate and karst aquifers, which are especially susceptible to contamination because of rapid recharge and transport processes. As part of the U.S. Geological Survey's National Water-Quality Assessment (NAWQA) Project, six carbonate principal aquifers across the United States were sampled for a large range of constituents, including geochemical age tracers, to understand the distribution of age and its relation to water quality and contaminant occurrence. These carbonate aquifers underlie parts of 18 states, are important drinking-water resources, and span a large range of hydrologic characteristics and climatic regimes. The principal aquifer sample networks generally consisted of public-supply wells (and some springs) that were selected based on an equal-area grid design to achieve spatially representative data. A total of 312 sites were sampled: 20 in the Basin and Range carbonate-rock aquifer system, 40 in the Biscayne aquifer, 74 in the Edwards-Trinity aquifer system, 60 in the Floridan aquifer system, 59 in the Ozark Plateaus aquifer system, and 59 in the Valley and Ridge and Piedmont and Blue Ridge carbonate-rock aquifers. Multiple age tracers and associated
\end{abstract}

analytes (tritium $\left[{ }^{3} \mathrm{H}\right]$, carbon- $14\left[{ }^{14} \mathrm{C}\right]$, sulfur hexafluoride $\left[\mathrm{SF}_{6}\right]$, dissolved and noble gases, and tritiogenic helium-3 $\left.\left[{ }^{3} \mathrm{He}_{\text {trit }}\right]\right)$ were measured and used to interpret groundwater residence times by using lumped parameter models. Based on measurements of ${ }^{3} \mathrm{H}$ and thresholds established from regional records of ${ }^{3} \mathrm{H}$ in precipitation, samples also were categorized as modern (recharged almost wholly since the early 1950s), premodern (recharged prior to the early 1950s), or mixed. Interpreted mean ages range from less than 1 year to more than 250,000 years. Although each principal aquifer might have a relatively small or large range of ages, there are notable differences among the aquifers. For example, the Biscayne aquifer and Valley and Ridge and Piedmont and Blue Ridge carbonate-rock aquifers contain predominantly modern water (100 and 80 percent, respectively). In contrast, the Ozark Plateaus aquifer system contains predominantly (greater than 50 percent) premodern water. The Basin and Range carbonate-rock aquifer system, Edwards-Trinity aquifer system, and Floridan aquifer system are more variable with relatively more mixed-age-category samples. Differences in groundwater ages reflect differences in geology, climate, recharge, and aquifer flow paths, and provide a foundation for understanding aquifer susceptibility and vulnerability to contaminants, geochemical processes, and factors affecting water quality. 


\title{
Abstracts-Geochemistry of Karst Systems
}

\section{A Reactive Transport Framework for Understanding Geochemical Transformations in Cave and Karst Systems}

\author{
By Jessica L. Oster ${ }^{1}$ and Jennifer L. Druhan ${ }^{2}$ \\ ${ }^{1}$ Vanderbilt University, Department of Earth and Environmental Sciences, Nashville, TN 37240. \\ ${ }^{2}$ University of Illinois, Department of Geology, Urbana-Champaign, IL 61801. \\ (Email: jessica.l.oster@vanderbilt.edu)
}

\begin{abstract}
Karst systems are useful for examining spatial and temporal variability in Critical Zone processes because they provide a window into the subsurface where waters have interacted with microbes, plants, soils, regolith, and bedrock across a range of length and time scales. Furthermore, these hydrologic pathways frequently include the precipitation of speleothems, which provide long-term archives of Critical Zone processes. Through sampling waters from soils and drip sites within a cave on a multi-year timescale, it is possible to observe how chemical signatures of the surface environment and climate are translated and modified along various flow paths. However, interpreting time-averaged speleothem records requires integration of observational data and simulation studies that provide a temporal bridge between long- and short-term processes. Reactive-transport models that are capable of simulating surface-to-cave transformations in water chemistry including stable and radiocarbon isotopes and cation concentrations, can help to address this need.

The reactive-transport model CrunchTope was adapted for karst systems and coupled with observations from Blue Spring Cave in Tennessee. Model development involves modification of the existing isotopic solid-solution model implemented in CrunchTope to accommodate the three isotopes of carbon (carbon-12, carbon-13, and carbon-14) with concurrent radioactive decay of carbon-14 in both fluid and solid phases. The chemical, isotopic, and mineralogic properties of the soils and host rocks at Blue Spring Cave are used to parameterize the model. A batch dissolution
\end{abstract}

experiment using a sample of the Monteagle Limestone that hosts Blue Spring Cave provides constraints on the chemical parameters used within the model.

Data from coordinated measurements of elemental and isotopic signatures of waters and gases moving along different flow paths within and between the soil, epikarst, and cave at Blue Spring Cave provide model validation. The range of variability in cave drip water oxygen isotope ratios $\left(\delta^{18} \mathrm{O}\right)$ indicates some drips are fed by fracture flow from the surface, while others are fed by diffuse flow paths. To strike a balance in limestone dissolution that supplies adequate calcium to the system without shifting the radiocarbon proportion of the drip water $\left(\Delta^{14} \mathrm{C}\right)$ to overly negative values, soil carbon dioxide partial pressure $\left(\mathrm{pCO}_{2}\right)$ and fluid-flow rates were constrained such that the modern soil-carbon source balances the contribution of radiocarbon-dead carbon from the host rock. Limestone dissolution raises calcium (Ca) concentrations and the stable carbon isotope composition of dissolved inorganic carbon $\left(\delta^{13} \mathrm{C}_{\mathrm{DIC}}\right)$ of the seepage water to within the range of measured values. For both drip types, $\delta^{13} \mathrm{C}_{\mathrm{DIC}}$ is inversely correlated with monthly rainfall, which is captured in the model through changes in seepage-water flow rate and soil $\mathrm{pCO}_{2}$. Measured drip water magnesium to calcium $(\mathrm{Mg} /$ $\mathrm{Ca})$ and strontium to calcium $(\mathrm{Sr} / \mathrm{Ca})$ ratios are successfully modeled by varying the amount of limestone dissolution followed by precipitation of secondary calcite occurring within the cave rather than the epikarst. This combined observation and modelling approach illustrates that processes occurring in the soil, epikarst, and cave itself each provide important controls on drip-water chemistry and demonstrates the importance of understanding the physical structure and hydrology of cave environments before interpreting isotopic and geochemical proxy records in speleothems. 


\title{
Using Initial Uranium Isotope Ratios in Speleothems as Paleoenvironmental Indicators
}

\author{
By Elli Ronay, ${ }^{1}$ Warren Sharp, ${ }^{2}$ David Furbish, ${ }^{1}$ Sebastian F.M. Breitenbach, ${ }^{3}$ and Jessica Oster ${ }^{1}$ \\ ${ }^{1}$ Vanderbilt University, Department of Earth and Environmental Sciences, Nashville, TN 37240. \\ ${ }^{2}$ Berkeley Geochronology Center, Berkeley, CA 94709 \\ ${ }^{3}$ Northumbria University, Department of Geography and Environmental Sciences, Newcastle upon Tyne, United Kingdom. \\ (Email: elli.ronay@vanderbilt.edu)
}

\section{Abstract}

The initial uranium isotope ratio $\left({ }^{234} \mathrm{U} / 238 \mathrm{U}\right)_{\mathrm{i}}$ of a speleothem is imparted from the dripwater at the time of carbonate deposition. Uranium isotope ratios in dripwater, $\left({ }^{234} \mathrm{U} / 238 \mathrm{U}\right)_{\mathrm{DW}}$, are influenced by processes along the flow path from the surface to the cave such as weathering of silicate and carbonate minerals in the soil and host rock, alpha-recoil into porewater during ${ }^{238} \mathrm{U}$ decay, and variability in host rock composition. The relative importance of many of these factors for $\left({ }^{234} \mathrm{U} /{ }^{238} \mathrm{U}\right)_{\mathrm{DW}}$ is related to water infiltration rate. Thus, speleothem $\left({ }^{234} \mathrm{U} / 238 \mathrm{U}\right)_{\mathrm{i}}$ can provide information about past changes in rainfall amount. A sub-annually resolved $\left({ }^{234} U / 238 \mathrm{U}\right)_{\mathrm{i}}$ record was developed for a speleothem from Mawmluh Cave in northeast India. This region receives meters of rainfall during the summer monsoon but little rainfall during the dry season. In northeast India and the regions influenced by the Asian Summer Monsoon, the traditional oxygen-18 to oxygen-16 isotope ratio $\left(\delta^{18} \mathrm{O}\right)$ speleothem climate proxy reflects moisture source and transport rather than rainfall amount. Likewise, in Mawmluh Cave speleothems, magnesium to calcium ratio $(\mathrm{Mg} / \mathrm{Ca})$ proxy data reflect rainfall seasonality and changes in winter rainfall rather than monsoon or annual rainfall (Ronay and others, 2019). Thus, speleothem $\left({ }^{234} U / 238 U\right)_{i}$ can provide valuable information about changes in infiltration rates that would complement these more widely used proxies.

Young aragonite $\left(\mathrm{CaCO}_{3}\right)$ speleothems from Mawmluh Cave support precise $\left({ }^{234} \mathrm{U} / 238 \mathrm{U}\right)_{\mathrm{i}}$ records with high temporal resolution because uranium concentrations are high (greater than 35 parts per million). Stalagmite MAW-0201 grew from 1964-2013 Common Era (CE). The stalagmite maintains relatively constant $\left({ }^{234} \mathrm{U} / 238 \mathrm{U}\right)_{\mathrm{i}}$ values from $1964-1984$, with a mean ratio of 0.890 plus or minus 0.006 , followed by a linear increase to 0.940 by $2000 \mathrm{CE}$. This trend does not correspond to any observed change in rainfall. Other controls can drive the $\left({ }^{234} \mathrm{U} /{ }^{238} \mathrm{U}\right)_{\mathrm{i}}$ trend, such as seismic activity in the region around 1984 CE. This event could have triggered a flow path change, bringing water in contact with less ${ }^{234} \mathrm{U}$-depleted host rock, fresh surfaces with ${ }^{234} \mathrm{U}$ loosely held in damaged lattice sites, or older secondary carbonate observed in the Mawmluh Cave host rock. To disentangle potential $\left({ }^{234} \mathrm{U} /{ }^{238} \mathrm{U}\right)_{\mathrm{i}}$ drivers, the evolution of each isotope in the soil-karst system was modeled using an advection-reaction equation parameterized with measured or estimated Mawmluh Cave variables. This model incorporated a surface area-dependent alpha-recoil factor, which adds ${ }^{234} \mathrm{U}$ to the fluid, and an advection-dependent weathering reaction that congruently dissolves both isotopes from the weathering material. Preliminary results indicate that heterogeneous host rocks and changing water flow paths can overprint potential infiltration signals in speleothem $\left({ }^{234} \mathrm{U} / 238 \mathrm{U}\right)_{\mathrm{i}}$ from cave systems like Mawmluh, limiting this as a paleohydrologic proxy in some locations, but providing opportunities to answer other important paleoenvironmental questions.

\section{Reference Cited}

Ronay, E.R., Breitenbach, S.F.M., and Oster, J.L., 2019, Sensitivity of speleothem records in the Indian Summer Monsoon region to dry season infiltration: Scientific Reports 9, article no. 5091. [Available at https://doi.org/10.1038/s41598-019-41630-2.] 


\title{
A Quantitative Record of Rainfall Using Speleothem Calcium and Strontium Isotopes
}

\author{
By Cameron B. de Wet, ${ }^{1}$ Andrea M. Erhardt, ${ }^{2}$ Naomi E. Marks, ${ }^{3}$ Warren D. Sharp,${ }^{4}$ Yiruo Xu, ${ }^{1}$ and \\ Jessica L. Oster ${ }^{1}$ \\ ${ }^{1}$ Vanderbilt University, Department of Earth and Environmental Sciences, 5726 Stevenson Center, 7th floor, Nashville, TN 37240. \\ ${ }^{2}$ University of Kentucky, Department of Earth and Environmental Sciences, 101 Slone Building, Lexington, KY 40506. \\ ${ }^{3}$ Lawrence Livermore National Laboratory, 7000 East Avenue, Livermore, CA 94550. \\ ${ }^{4}$ Berkeley Geochronology Center, 2455 Ridge Road, Berkeley, CA 94709. \\ (Email: cameron.de.wet@vanderbilt.edu)
}

\section{Abstract}

Variations in speleothem oxygen and carbon isotope ratios (oxygen-18 to oxygen- $16\left[\delta^{18} \mathrm{O}\right]$ and carbon-13 to carbon-12 $\left.\left[\delta^{13} \mathrm{C}\right]\right)$ and elemental ratios such as magnesium/ calcium $(\mathrm{Mg} / \mathrm{Ca})$ and phosphorus/calcium $(\mathrm{P} / \mathrm{Ca})$ are used to infer qualitative changes in past rainfall, but the complex controls on these proxy systems preclude more quantitative assessments of rainfall variability in most cases. Recently, speleothem calcium isotope ratios $\left(\delta^{44 / 40} \mathrm{Ca}\right.$ or $\left.\delta^{44 / 42} \mathrm{Ca}\right)$ have been explored as a new, potentially quantitative proxy for prior calcite precipitation (PCP) and thus, for effective rainfall. During carbonate mineral precipitation, the lighter Ca isotope $\left({ }^{40} \mathrm{Ca}\right)$ preferentially enters the solid phase because of kinetic isotope fractionation, leaving the fluid relatively enriched in the heavier Ca isotope $\left({ }^{44} \mathrm{Ca}\right)$. During periods of increased rainfall and infiltration, less PCP will occur in the epikarst because of an increased groundwater pressure head, and cave dripwaters and speleothems are expected to be less enriched in ${ }^{44} \mathrm{Ca}$. Conversely, during drier periods, there will be more opportunity for PCP to occur, and cave dripwaters and speleothems are expected to be more enriched in ${ }^{44} \mathrm{Ca}$. Although promising, this new proxy system has yet to be widely applied across climate and geologic settings, and questions remain as to how it should be utilized in individual cave systems most effectively.

Delta $(\delta)^{44 / 40} \mathrm{Ca}$ isotope data were collected for a stalagmite (WMC1) from White Moon Cave (WMC) in coastal California. WMC1 grew from approximately 8,600 to 6,900 calendar years before present, representing much of the mid- and late Holocene, including the 8.2 thousand-year (ka) event. The $8.2 \mathrm{ka}$ event was a roughly 160 -year-long interval of cooler temperatures in the Northern Hemisphere identified by a 1 to 2 permil oxygen isotope excursion in Greenland ice cores. It was likely caused by a suppression of Atlantic Meridional Overturning Circulation driven by meltwater flux from the Greenland ice sheet and represents one of the most extreme climate perturbations of the otherwise relatively stable Holocene. Proxy evidence indicates drier conditions in the Northern Hemisphere tropics and wetter conditions in northern Europe and parts of the Southern Hemisphere tropics over the $8.2 \mathrm{ka}$ event. However, the $8.2 \mathrm{ka}$ event has been poorly characterized in western North America because of a paucity of records with sufficient temporal resolution.

$\mathrm{WMC} 1 \delta^{44 / 40} \mathrm{Ca}$ data values range from -0.4 to -1.2 permil bulk silicate earth (measured relative to the NIST 915B standard) and show decadal-scale fluctuations throughout the record, with higher frequency variability and relatively negative values from roughly 8,250 to 8,050 calendar years before present, indicating less PCP and an intermittently wetter climate over the course of the $8.2 \mathrm{ka}$ event. A one-box Rayleigh fractionation model parameterized using modern climate data and $\delta^{44 / 40} \mathrm{Ca}$ data from dripwaters, the marble host rock, and calcite grown on artificial substrates installed in the cave was used to quantify PCP variability and rainfall response to the $8.2 \mathrm{ka}$ event. The fraction of originally dissolved $\mathrm{Ca}$ removed because of $\mathrm{PCP}$ in the epikarst ranges from 0 to 76 percent, corresponding to rainfall ranging from 350 to at least 900 millimeters per year over the course of the full WMC1 record. Nine hundred millimeters per year represents a threshold above which specific rainfall rates cannot be estimated because the calculated fraction of $\mathrm{Ca}$ removed as a result of $\mathrm{PCP}$ equals or is less than 0 percent, indicating that no PCP has occurred.

The study of $\mathrm{Ca}$ isotope cycling in karst environments shows promise for quantitative reconstructions of rainfall, but the application of the quantitative model at WMC is complicated by the large degree of variability in $\delta^{44 / 40} \mathrm{Ca}$ in the marble host rock, which is used to parameterize the model, as well as by potential spatial variability in $\mathrm{Ca}$ isotope cycling in the epikarst as a result of water mixing and (or) inconsistent dissolution and mineral precipitation rates. 
To complement the $\delta^{44 / 40} \mathrm{Ca}$ data and explore variations in host-rock dissolution, strontium $(\mathrm{Sr})$ isotope $\left({ }^{87} \mathrm{Sr} /{ }^{86} \mathrm{Sr}\right)$ data were collected for WMC1 and the WMC cave system. The WMC1 ${ }^{87} \mathrm{Sr} /{ }^{86} \mathrm{Sr}$ data show values that vary between end members defined by a less radiogenic marble host rock and a more radiogenic soil weathered from diorite above the cave. More radiogenic speleothem values are interpreted as reflecting greater contribution from the soil relative to the marble host rock, indicating less host-rock dissolution, a shorter water residence time, and increased rainfall. Less radiogenic speleothem values are interpreted as indicating a greater contribution from the marble host rock, thus more host-rock dissolution and relatively drier conditions. WMC1 ${ }^{87} \mathrm{Sr} /{ }^{86} \mathrm{Sr}$ data display consistently more radiogenic values over the $8.2 \mathrm{ka}$ event, indicating wetter conditions relative to the rest of the record and broadly supporting the interpretation of the $\delta^{44 / 40} \mathrm{Ca}$ isotope, elemental ratio $(\mathrm{Mg} / \mathrm{Ca}, \mathrm{P} / \mathrm{Ca})$, and $\delta^{18} \mathrm{O}$ and $\delta^{13} \mathrm{C}$ records. 


\title{
Geochemical Characterization and Comparison of Karst and Mineral Springs of Southwest Central Indiana
}

\author{
By Stephanie LeGare, ${ }^{1}$ Lindsey Rasnake, ${ }^{1}$ Tracy Branam, ${ }^{2}$ Sarah Burgess, ${ }^{3}$ and Lee Florea ${ }^{2}$ \\ 'Indiana University, O'Neill School of Public and Environmental Affairs, 1315 E. 10th St., Bloomington, IN 47405. \\ ${ }^{2}$ Indiana Geological and Water Survey, 1001 E. 10th St., Bloomington, IN 47408. \\ ${ }^{3}$ Indiana University, Department of Earth and Atmospheric Sciences, 1001 E. 10th St., Bloomington, IN 47408. \\ (Email: slegare@iu.edu)
}

\begin{abstract}
Historically, southwest central Indiana's (SWCI) karst landscape is synonymous with springs that are important to growing communities as sources of domestic, agriculture, livestock, and commercial water use. The principal bedrock aquifers in this area are contained within the Stephensport, Blue River, and Sanders Groups of Mississippian age, which consist of interbedded carbonates and siliciclastics. The predominant physiographic landscape is the Mitchell Plateau and the Crawford Upland. The Indiana Geological and Water Survey, in conjunction with the Indiana University Center for Rural Engagement, seeks to compile new water-quality data for 100 perennial springs in 10 counties of SWCI and merge these results with historical data in an accessible geospatial database that can be used to foster community engagement, regional planning, and further study.

Water-quality assessments include field measurements of temperature, $\mathrm{pH}$, specific conductivity, dissolved oxygen, and discharge. Samples were collected and analyzed for nutrients such as nitrate, nitrite, orthophosphate, and ammonia, and dissolved organic carbon. Samples also were analyzed for total alkalinity, the major ions (calcium, chloride, fluoride,
\end{abstract}

magnesium, potassium, sodium, and sulfate), and selected trace elements including aluminum, arsenic, boron, bromide, cadmium, chromium, iron, lead, lithium, manganese, strontium, and zinc. Historically, calcium, magnesium, and alkalinity concentrations have been higher in karst springs, and levels of trace elements have been higher in mineral springs. Saturation indices will be calculated by using the chemical activities of the dissolved cations and anions to determine whether minerals will be precipitated or dissolved; this will also emphasize the differences between karst and mineral springs. A subset of the 100 springs includes an analysis for the stable isotopes of hydrogen- 2 and oxygen-18 and dissolved inorganic carbon-13; a smaller subset of the mineral springs will also include analyses of sulfur-34 isotopes from sulfate. The analyses of these isotopes will be used to evaluate the carbon cycle and determine whether recharge to the aquifer is dominated by seasonal influences owing to precipitation or regional influences attributed to an ancient deep-water aquifer. It is assumed that recharge to the aquifer is based more on seasonal factors for karst springs and regional factors for mineral springs. During the fall 2019 sampling season, field measurements were obtained for 33 sites in Monroe, Greene, and Orange Counties; sampling will continue in fall 2020. 


\title{
Comparing Land Use and Groundwater Chemistry Across Karst Basins in the Mitchell Plateau of South-Central Indiana
}

\author{
By Sarah Burgess, ${ }^{1}$ Lee Florea, ${ }^{2}$ Tracy Branam, ${ }^{2}$ Stephanie LeGare, ${ }^{3}$ and Lindsey Rasnake ${ }^{3}$ \\ ${ }^{1}$ Indiana University, Department of Earth and Atmospheric Sciences, 1001 E. 10th St, Bloomington, IN 47408. \\ 2Indiana Geological and Water Survey, 1001 E. 10th St., Bloomington, IN 47408. \\ ${ }^{3}$ Indiana University, O'Neill School of Public and Environmental Affairs, 1315 E. 10th St., Bloomington, IN 47405. \\ (Email: burgesss@iu.edu)
}

\begin{abstract}
The Mitchell Plateau of south-central Indiana is a classic karst landscape with mixed land use, variable surface cover, and rural communities. On the plateau, a well-developed epikarst facilitates the mixing of meteoric, surface, and groundwater that recharges extensive subsurface drainage systems and relates surface processes to the chemistry of the underlying karst aquifers. As part of a larger study, semimonthly samples from four sites in two adjacent karst basins were used to document processes at points of recharge, throughput, and output. Three sites are within the Lost River Karst Basin: Flood Creek, Wesley Chapel Gulf, and Orangeville Rise. Flood Creek is a sinking stream bordered by farm fields. Wesley Chapel Gulf is a karst window where aquifer throughput in the Lost River Cave System, fed by the largest sinking stream in Indiana, resurfaces. Orangeville Rise is the second largest spring in Indiana and one of two springs where karst groundwater rises from the Lost River Karst Basin. The fourth site is throughput in the underground conduit of Bluespring Caverns in the Blue Spring Karst Basin.

The Lost River Karst Basin is fed principally by allogenic recharge and is more than 40 percent agricultural land use. In contrast, the smaller Blue Spring Karst Basin is largely supplied by autogenic recharge and is primarily low-density residential, pasture, and woodland. The different recharge regimes and land use in these basins produce distinguishable geochemical signals in carbon, nutrient, and other ions.

Non-purgeable organic carbon (NPOC) is lower in caves
\end{abstract}

and springs than at recharge sites, reflecting the oligotrophic conditions expected for karst groundwater at this latitude. The relation between NPOC and total nitrogen is more variable in the allogenic basin when compared to the autogenic basin. Furthermore, carbon to nitrogen ratios show positive linear relations with NPOC, but with an offset between allogenic and autogenic karst basins, suggesting different sources of organic carbon. Elevated sodium concentrations in water from Bluespring Caverns and in water from Wesley Chapel Gulf indicate longer soil-water interactions in the epikarst compared with those in Flood Creek and the Orangeville Rise. Proportionalities of chloride, bromide, fluoride, and nitrogen species discriminate surficial inputs from road salts, sewage, and fertilizer.

Climate change and synoptic weather fluctuations present further considerations for these interpretations. According to the Purdue University Entomology Extension Indiana Climate and Weather report-10/10/2019, during the spring of 2019, counties including this study area experienced 150 to 200 percent of the 1981-2010 normal precipitation (web page, accessed January 24, 2020, at https://extension.entm.purdue.edu/newsletters/pestandcrop/ article/indiana-climate-and-weather-report-10-10-2019/). Increased precipitation and subsequent flooding may alter agricultural practices and change contamination potential. As monitoring continues into 2020, these interpretations are expected to become more robust as they are corroborated or contradicted by new data. 


\title{
Source Water Investigation of the Fort Stanton-Snowy River Cave System, New Mexico
}

\author{
By Christina L. Ferguson, ${ }^{1}$ Johanna M. Blake, ${ }^{1}$ and Keely E. Miltenberger ${ }^{1}$
}

'U.S. Geological Survey, 6700 Edith Boulevard NE, Albuquerque, NM 87113.

(Email: cferguson@usgs.gov,jmtblake@usgs.gov, and kmiltenberger@usgs.gov)

\begin{abstract}
The Fort Stanton-Snowy River cave system, located in the eastern foothills of the Sierra Blanca Mountains in south-central New Mexico, is entirely developed within the Permian San Andres Formation, which consists of limestones and minor evaporite beds. The Snowy River refers to a unique calcite deposit that resembles a white riverbed within the cave. The calcite deposit has been mapped for over 11 cave miles, making it one of the longest speleothems in the world. Because of its unique and delicate nature, its preservation is of utmost importance to cave and natural resource managers. However, the source of water that precipitates the calcite is unknown. Flooding of the Snowy River portion of the cave has been roughly correlated to large precipitation and runoff events within the local watershed. Two small creeks in the area, Little Creek and Eagle Creek, have been hypothesized as possible sources of water to the cave. To understand if
\end{abstract}

these two creeks contribute to subsurface water, patterns of major ions and trace elements, and isotopes of water $\left({ }^{18} \mathrm{O} /{ }^{16} \mathrm{O}\right.$ and $\left.{ }^{2} \mathrm{H}\right)$ and strontium $\left({ }^{87} \mathrm{Sr} r{ }^{86} \mathrm{Sr}\right)$ of the surface waters and groundwater were analyzed. To compare with the water samples, the same constituents for the rocks that are part of the local geology and cores of the Snowy River calcite deposit also were analyzed. No dye-tracing studies were done because of possible effects on the delicate and largely unknown microbial population that exists within the cave and is responsible for the black manganese oxide coating that covers most of the walls within the Snowy River portion of the cave. Geochemical analyses of the waters show that cave waters are similar in composition to Eagle Creek water and nearby groundwater, and dissimilar to Little Creek water. Analyses of the rocks show similarities between the calcite core samples and limestone collected from the lowest member of the San Andres Formation. 


\title{
Stable Isotope and Geochemical Characterization of Nutrient Sources and Surface Water Near a Confined Animal Feeding Operation in the Big Creek Watershed of Northwest Arkansas
}

\author{
By Kelly Sokolosky and Phillip D. Hays² \\ ${ }^{1}$ University of Arkansas, Department of Geosciences, 340 N. Campus Dr., Fayetteville, AR 72701. \\ ${ }^{2}$ U.S. Geological Survey, 700 W. Research Blvd., Fayetteville, AR 72701. \\ (Email: kelly.sokolosky@gmail.com)
}

\begin{abstract}
A concentrated animal feeding operation (CAFO) established in Newton County, Arkansas, near Big Creek, a tributary of the Buffalo National River, raised concern about potential degradation of water quality in the karst watershed. In this study, isotopic tools were combined with standard geochemical approaches to characterize nutrient sources and dynamics in the Big Creek watershed. An isotopic and geochemical reference database of potential nutrient sources in the Big Creek watershed was constructed based on samples collected from representative potential sources. Nutrient sources and stream samples were analyzed for delta $(\delta)^{15} \mathrm{~N}_{-} \mathrm{NO}_{3}, \delta^{18} \mathrm{O}-\mathrm{NO}_{3}$, and a suite of selected dissolved ions. Data provide evidence of modification of potential local nutrient source signatures by nitrification, atmospheric deposition, evaporation, and denitrification. Samples taken from the CAFO waste pond, a septic system, field and parking lot runoff, fertilizer, and hog manure exhibited different $\delta^{15} \mathrm{~N}-\mathrm{NO}_{3}$ and $\delta^{18} \mathrm{O}-\mathrm{NO}_{3}$ values as compared to stream samples. Stream $\delta^{15} \mathrm{~N}-\mathrm{NO}_{3}$ and $\delta^{18} \mathrm{O}-\mathrm{NO}_{3}$ values cannot be explained by direct input of any one of these potential sources without modification of the isotopic composition by mixing or fractionation. Big Creek nitrate isotope values (-3.4 per mil [\%] to $6.7 \%{ }_{0} \delta^{15} \mathrm{~N}-\mathrm{NO}_{3}$ and -7.6 to $9.1 \% 0 \delta^{18} \mathrm{O}-\mathrm{NO}_{3}$ ) were similar to values expected from nitrification of nitrogen stored in soils sampled in the watershed (2.8 to $7.6 \% 0 \delta^{15} \mathrm{~N}^{-\mathrm{NO}_{3}}$ and 3.4 to $\left.4.8 \% \delta^{18} \mathrm{O}-\mathrm{NO}_{3}\right)$.
\end{abstract}

\section{Introduction and Hydrogeologic Setting}

Traditional methods of geochemical analysis often do not provide adequate characterization of nutrient sources in watersheds. This study applied a combined approach of traditional water-quality analysis and stable-isotope geochemistry to characterize nutrient concentrations, sources, transport pathways, and transformation processes in the Big Creek watershed in northern Arkansas (fig. 1). The objectives of this study were (1) to establish a database of isotopic analyses of potential nutrient sources, and (2) to use nitrate isotopes and surface-water sampling for characterizing sources, transport, and transformations (Sokolosky, 2019).

Agricultural practices such as hay cultivation and the raising of beef cattle, swine, and poultry have long been prevalent in the Big Creek watershed. In 2013, a concentrated animal feeding operation (CAFO) was established 0.5 mile from Big Creek near Mt. Judea, Arkansas, approximately 6 miles upstream of the Buffalo National River (fig. 1). Waste from the 6,500-hog-capacity farm was spread onto almost 700 acres of surrounding property during the years of operation, including fields 1 and 12 on figure 1 . The farm was closed by the Arkansas Department of Environmental Quality in January 2020.

The CAFO is located on the Boone Formation near the Springfield Plateau and the Boston Mountains boundary (Chandler and Ausbrooks, 2003). The hydrogeology of the Springfield Plateau aquifer, which includes the Boone Formation, is typical of karst, with effective but not often visible connections between surface water and groundwater, rapid response to storm events, and bimodal porosity distribution (Imes and Emmett, 1994; Hays and others, 2016). Rapid transport of surface flow into the subsurface through focused-flow conduits equates to little attenuation of contaminants such as nitrate (Peterson and others, 2002). Most recharge occurs rapidly through pathways such as sinkholes, fractures, and losing streams (Brahana and others, 2005). 


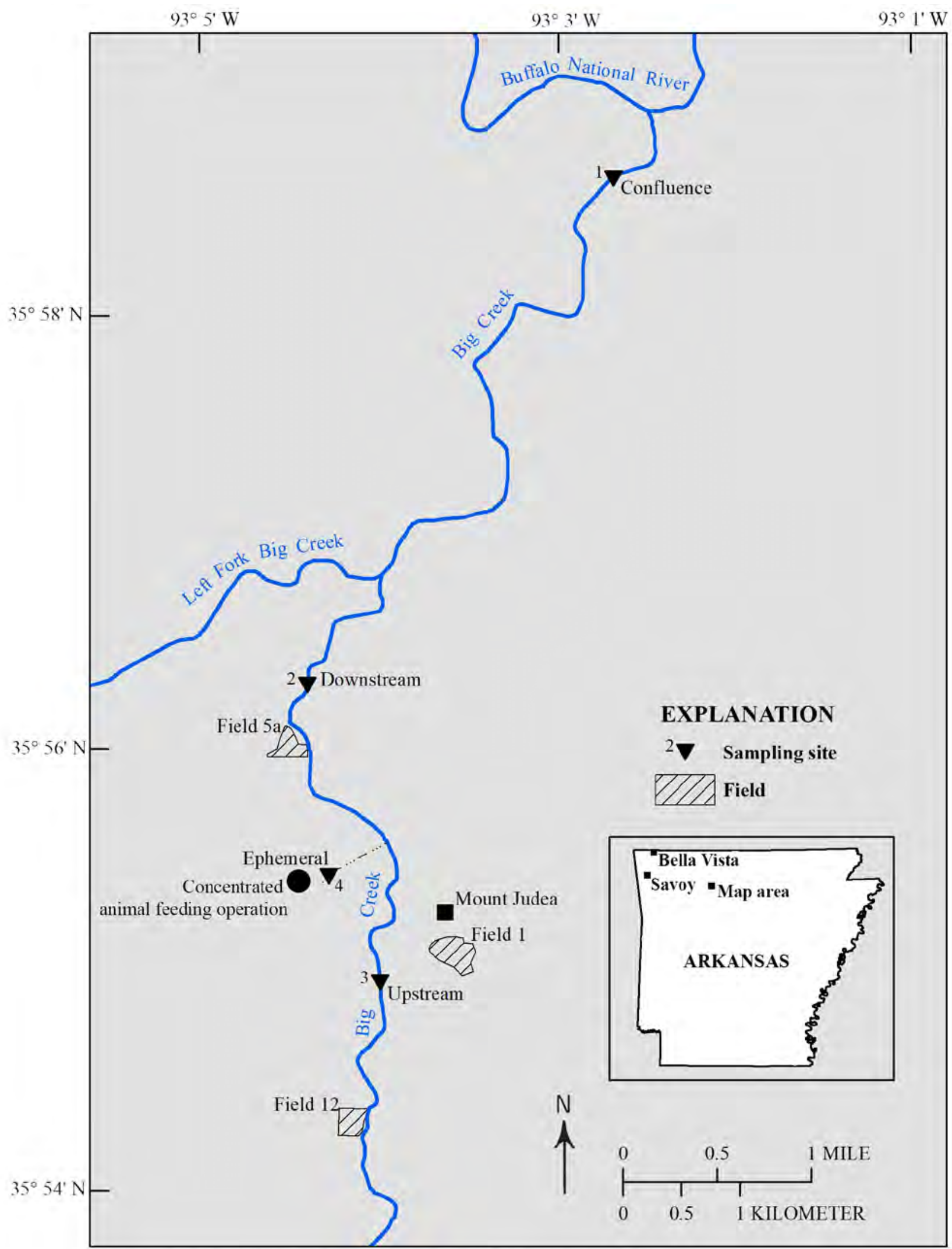

Base modified from U.S. Geological Survey 1:100,000-scale digital data North American Datum of 1983

Figure 1. Stream sampling sites along Big Creek in Newton County, Arkansas. 
The Big Creek Research and Extension Team (BCRET) began monitoring water quality in Big Creek in September 2013. Nitrate and nitrite concentrations were below the drinking-water standard of 10 milligrams per liter $(\mathrm{mg} / \mathrm{L})$ as nitrogen; however, nitrate concentrations downstream of the farm were greater than those measured at an upstream site (BCRET, 2016). Nutrient concentrations upstream and downstream of the CAFO are low relative to similar regional watersheds that contain CAFOs (Sharpley and others, 2017). Fields and Halihan (2016) conducted electrical resistivity imaging (ERI) surveys and soil sampling in the Big Creek watershed. The ERI surveys identified fracture zones and conduits and highlighted the potential for rapid subsurface transport pathways below slurry-application fields. Soil sample delta $(\delta)^{15} \mathrm{~N}-\mathrm{N}$ values ranged from 3.8 per mil $(\%)$ to 6.6\% across all sites (Fields and Halihan, 2016).

\section{Methods}

\section{Field Methods}

A database of isotopic compositions and geochemical characteristics of nutrient sources was developed by analyzing samples from sites representative of potential sources. Waste-holding ponds were sampled at the CAFO and the University of Arkansas (UA) Swine Farm at Savoy. However, because of laboratory scheduling, holding times were exceeded although the samples had been prepped and stored properly. A second set of samples at the CAFO were collected for geochemical analysis but were denied. Therefore, two samples (old Savoy lagoon; fresh Savoy lagoon) were collected from the Savoy waste pond to assess the general comparability of the dated samples from the CAFO. Hog manure was sampled at the UA Swine Farm due to sampling restrictions instituted at the CAFO. The UA Broiler Research Unit provided a broiler litter sample. Both fresh and old cow manure samples were taken from field 1 near Mt. Judea for comparison (fig. 1).

Manure and litter samples were extracted with deionized water for analysis. A commonly used inorganic fertilizer variety, 13-13-13 (13 percent each of nitrogen, phosphorus, and potassium), was dissolved in deionized water for analysis. Manure, litter, and inorganic fertilizer data were proportionally converted to $200 \mathrm{mg} / \mathrm{L}$ for consistency. A residential septic-system sample was collected near Bella Vista, Arkansas, because a readily accessible septic system could not be located near Mt. Judea. Runoff samples from fields 1, 5A, and 12 were collected during a 10.3-centimeter $(\mathrm{cm})$ rainfall event. The runoff samples were collected using ISCO automatic water samplers in edge-of-field BCRET flumes positioned in topographically low areas. All three fields were used for cattle grazing and hay production, and fields 1 and 12 were amended with CAFO waste. Parking lot runoff was manually collected during a $1.5-\mathrm{cm}$ rainfall event in Mt. Judea.

Four stream sites were chosen for water sample collection: (1) U.S. Geological Survey (USGS) site no. 07055814, approximately 0.5 mile upstream of the confluence of Big Creek with the Buffalo River, (2) USGS site no. 07055790 on Big Creek downstream of surface-water discharge from the CAFO, (3) Big Creek upstream of surface-water discharge from the CAFO, and (4) an ephemeral stream between the CAFO and Big Creek (fig. 1). Two samples (5A and B) were collected from the ephemeral stream early in the study after a $2.2-\mathrm{cm}$ rainfall event: one dip sample from the stream, and one sample collected from the stream using a BCRET ISCO automatic sampler. Dip samples were collected from all four stream sites twice after rainfall ( $\mathrm{S} 1$ samples $=2.1 \mathrm{~cm}$ and $\mathrm{S} 2$ samples $=1.8 \mathrm{~cm}$ ). Dip samples were collected from the three Big Creek sites twice during base-flow conditions (B1 and B2 samples, no rainfall for 7 days). All samples were chilled until analysis, and all samples except the inorganic fertilizer were filtered to 0.45 micron prior to analysis.

\section{Analytical Methods}

All stream and runoff samples were measured for $\mathrm{pH}$ and specific conductance at the time of collection. Arkansas Water Resources Lab (AWRC) analyzed anions, total phosphorus (TP), ammonia $\left(\mathrm{NH}_{3}-\mathrm{N}\right)$, nitrate $\left(\mathrm{NO}_{3}-\mathrm{N}\right)$, and nitrate plus nitrite $\left(\mathrm{NO}_{3}+\mathrm{NO}_{2}-\mathrm{N}\right)$. Results of these analyses along with analytical methods, reporting limits, and method detection limits are shown in table 1.

The UA Stable Isotope Lab (UASIL) conducted nitrate isotopic analysis using the microbial denitrifier method and a Thermo Scientific Gas Bench II interfaced to a Thermo Scientific Delta Plus XP CF-IRMS (Sigman and others, 2001; McIlvin and Casciotti, 2011; Coplen and others, 2012). Larger sample volumes (3 to 5 milliliters) were used in sample analysis to account for low nitrate concentrations in samples. Instrument precision for both $\delta^{15} \mathrm{~N}-\mathrm{NO}_{3}$ and ${ }^{18} \mathrm{O}-\mathrm{NO}_{3}$ was plus or minus $0.3 \%$. 


\section{Results and Discussion}

\section{Potential Nutrient Sources}

Source samples in this study exhibit a distinct range of geochemical signatures. Manure, Savoy lagoon, and fertilizer samples had higher concentrations of most analytes when compared to runoff and stream samples collected near the CAFO (table 1). Ammonia concentrations of source samples ranged from 0.11 to $1,040 \mathrm{mg} / \mathrm{L}$ with little to no nitrate detected (range of 0 to $0.34 \mathrm{mg} / \mathrm{L}$; table 1). Such results for nitrogen-species concentrations are expected because of the oxidation state of nitrogen in these media and indicates that ammonia from these potential sources is nitrified as it moves from the source area to groundwater discharge points or streams. Nitrate concentration in runoff from Field 1 was $0.34 \mathrm{mg} / \mathrm{L}$, the highest of all sources, likely indicating that a portion of the nutrient transport to Big Creek was occurring by overland runoff.
Source $\delta^{15} \mathrm{~N}_{-\mathrm{NO}_{3}}$ values ranged from -15.4 to $54.8 \%$, and $\delta^{18} \mathrm{O}-\mathrm{NO}_{3}$ ranged from -7.2 to $59.1 \%$ (figure 2 and table 2). The fresh Savoy lagoon, fresh cow manure, and CAFO liquids pond samples did not contain sufficient nitrate concentrations to obtain isotopic ratios. Low potential source sample nitrate concentrations (below $0.38 \mathrm{mg} / \mathrm{L}$ ) equate to lower precision in isotopic analysis. The old Savoy lagoon sample had an unusually enriched $\delta^{18} \mathrm{O}-\mathrm{NO}_{3}$ value of $59.1 \%$, consistent with values expected of atmospheric nitrate. However, either atmospheric deposition of nitrogen or extreme evaporation of lagoon water - enriching the water available to nitrate-producing microbes - could explain the isotopically heavy values. The preferential uptake of the light oxygen isotope during biological processes could also explain the enriched $\delta^{18} \mathrm{O}-\mathrm{NO}_{3}$ value (Kendall, 1998). The CAFO solids pond sample $\delta^{15} \mathrm{~N}^{-\mathrm{NO}_{3}}$ value was $4.2 \%$, and $\delta^{18} \mathrm{O}-\mathrm{NO}_{3}$ was $-7.2 \%$, within the typical range for both manure and septic waste and ammonium $\left(\mathrm{NH}_{4}\right)$ in fertilizer and rain.

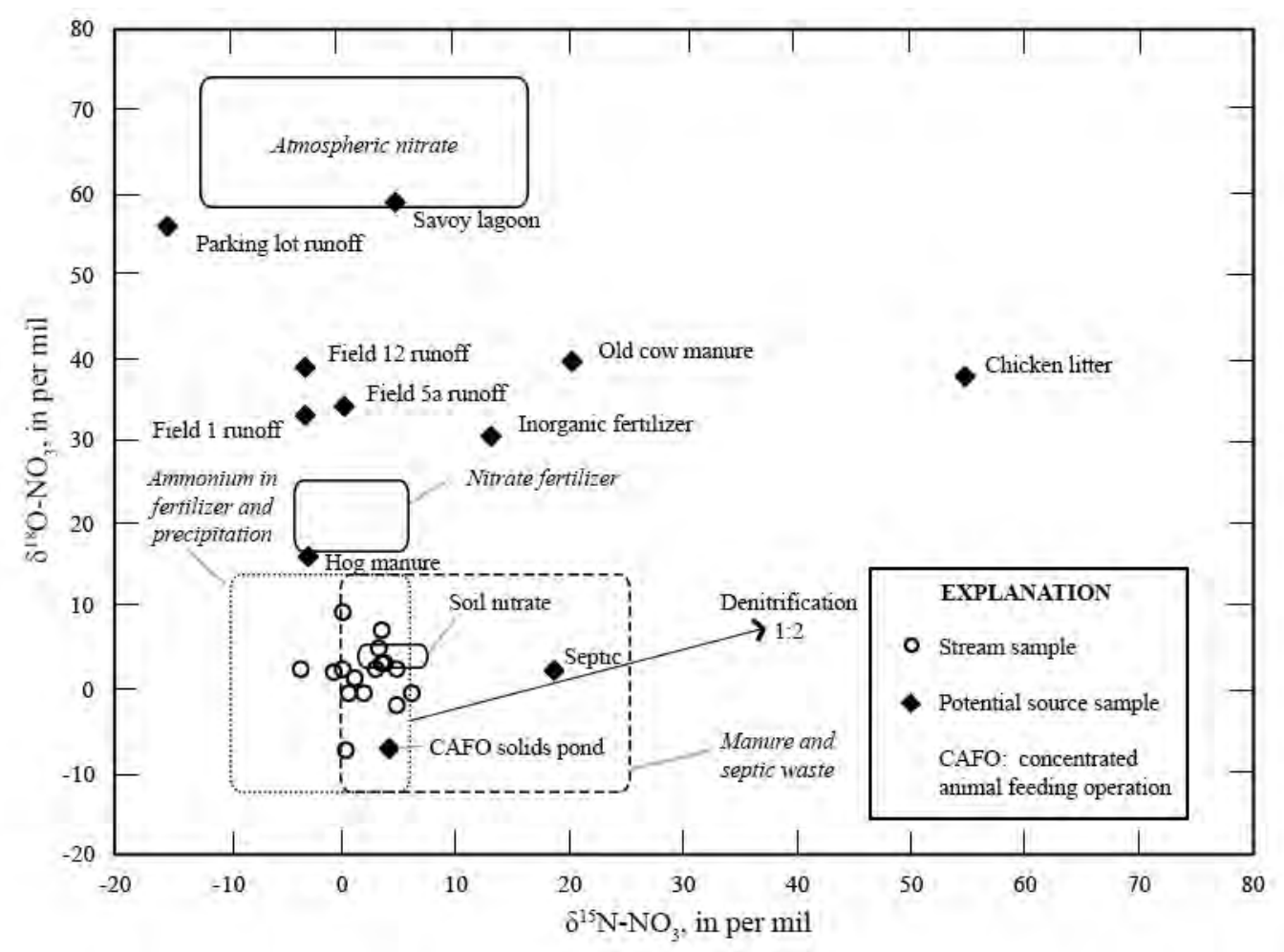

Figure 2. Potential source and stream sample $\delta^{15} \mathrm{~N}-\mathrm{NO}_{3}$ versus $\delta^{18} 0-\mathrm{NO}_{3}$. Boxes are representative of indicated nitrogen sources in italics (modified from Kendall, 1998). Soil $\delta^{15} \mathrm{~N}-\mathrm{NO}_{3}$ is modified from Fields and Halihan (2016). Soil $\delta^{18} 0-\mathrm{NO}_{3}$ is derived from stream $\delta^{18} 0-\mathrm{NO}_{3}$ and estimated atmospheric $\delta^{18} 0-\mathrm{NO}_{3}$. 
Table 1. Anion and nutrient concentrations of potential source and stream samples in the Big Creek watershed, including reporting limits, method detection limits, and methods.

[Source samples are shaded. mg/L, milligrams per liter; TP, total phosphorus; $\mathrm{CaCO}_{3}$, Alkalinity as $\mathrm{mg} / \mathrm{L} \mathrm{CaCO}{ }_{3}$; $\mathrm{SpC}$, specific conductance; $\mu \mathrm{S} / \mathrm{cm}$, microsiemens per centimeter; --, no data; *, below $\mathrm{MDL}$; E, below reporting limit and above MDL; CAFO, concentrated animal feeding operation; S, collected after rainfall; B, collected during base-flow conditions; MDL, Method Detection Limit; EPA, U.S. Environmental Protection Agency; APHA, American Public Health Association]

\begin{tabular}{|c|c|c|c|c|c|c|c|c|c|c|c|c|}
\hline Site identifier & Sample name & $\begin{array}{c}\mathrm{Br}^{-} \\
(\mathrm{mg} / \mathrm{L})\end{array}$ & $\begin{array}{c}\mathrm{Cl}^{-} \\
(\mathrm{mg} / \mathrm{L})\end{array}$ & $\begin{array}{c}\mathrm{F}^{-} \\
(\mathrm{mg} / \mathrm{L})\end{array}$ & $\begin{array}{c}\mathrm{SO}_{4}^{-2} \\
(\mathrm{mg} / \mathrm{L})\end{array}$ & $\begin{array}{c}\mathrm{NO}_{3}{ }^{-}+\mathrm{NO}_{2}-\mathrm{N} \\
(\mathrm{mg} / \mathrm{L})\end{array}$ & $\begin{array}{l}\mathrm{NO}_{3}^{-}-\mathrm{N} \\
(\mathrm{mg} / \mathrm{L})\end{array}$ & $\begin{array}{l}\mathrm{NH}_{3}-\mathrm{N} \\
(\mathrm{mg} / \mathrm{L})\end{array}$ & $\begin{array}{c}\mathrm{TP} \\
(\mathrm{mg} / \mathrm{L})\end{array}$ & $\begin{array}{l}\mathrm{CaCO}_{3} \\
(\mathrm{mg} / \mathrm{L})\end{array}$ & $\mathrm{pH}$ & $\begin{array}{c}\mathrm{SpC} \\
(\mu \mathrm{S} / \mathrm{cm})\end{array}$ \\
\hline $1 \mathrm{~A}$ & Old Savoy lagoon & -- & 440 & $0 *$ & 25 & 0.16 & 0.11 & 350 & -- & 1,189 & 7.77 & 6,770 \\
\hline 1B & Fresh Savoy lagoon & $0^{*}$ & 543 & $0 *$ & 43 & 0.17 & $0^{*}$ & 230 & 53 & -- & -- & -- \\
\hline 2 & Hog manure & 0* & 82 & 380 & 55 & 0.23 & $0^{*}$ & 430 & 400 & 89 & 6.08 & 5,260 \\
\hline 3 & Fresh cow manure & 0.12 & 98 & 3.4 & $0^{*}$ & 0.14 & $0 *$ & 307 & 38 & 490 & 7.19 & 1,730 \\
\hline 4 & Chicken litter & 0* & 1,100 & 850 & 3,900 & 1.4 & $0 *$ & 670 & 81 & 504 & 6.28 & 7,310 \\
\hline 6 & CAFO solids pond & $0^{*}$ & 590 & 0* & 44 & 0.22 & $0^{*}$ & 1,040 & 75 & 4,135 & 8.16 & 4,580 \\
\hline 7 & CAFO liquids pond & 0* & 470 & 0.6 & 6.2 & 0.12 & 0.11 & 450 & 110 & 2,987 & 7.96 & 3,310 \\
\hline 8 & Old cow manure & $0^{*}$ & 15 & 0.2 & $0^{*}$ & 0.05 & $0^{*}$ & 7.1 & 34 & 246 & 7.06 & 298 \\
\hline 9 & Inorganic fertilizer & 1.3 & 230 & 4.1 & 110 & 0.8 & $0^{*}$ & 170 & 200 & -- & 6.95 & 64 \\
\hline 10 & Septic effluent & 0.1 & 52 & $0 *$ & 20 & 0.06 & 0* & 84 & 7.7 & 278 & 6.55 & 1,310 \\
\hline 11 & Field 1 runoff & -- & 2.7 & 0.2 & 2.5 & 0.34 & 0.38 & 0.51 & 0.71 & -- & 7.5 & 51 \\
\hline 12 & Field 5A runoff & $0^{*}$ & 2.1 & 0.2 & 2.3 & 0.8 & 0.37 & 0.39 & 0.87 & 46 & 7.28 & 68 \\
\hline 13 & Field 12 runoff & $0^{*}$ & 1.2 & 0.1 & 2 & 0.19 & 0.22 & 0.14 & 0.37 & 15 & 7.35 & 60 \\
\hline 32 & Parking lot runoff & $0.006^{*}$ & E 0.3 & $0 *$ & 1.4 & 0.08 & 0.18 & 0.11 & 0.033 & -- & 6.62 & 52 \\
\hline 14 & Upstream S1 & $0.006^{*}$ & 2.8 & 0.2 & 3.2 & 0.17 & 0.19 & $0^{*}$ & 0.03 & 54 & 7.82 & 85 \\
\hline 15 & Upstream S2 & $0^{*}$ & 1.4 & 0.2 & 3.9 & E 0.03 & 0.17 & E 0.01 & 0.052 & 56 & 7.89 & 96 \\
\hline 16 & Upstream B1 & $0.01 *$ & 1.2 & $0^{*}$ & 3.9 & 0.2 & 0.18 & E 0.04 & 0.024 & 25 & 8.05 & 119 \\
\hline 17 & Upstream B2 & $0.011^{*}$ & 2 & $0.021 *$ & 4.3 & 0.09 & 0.05 & E 0.02 & E 0.01 & 56 & 7.64 & 235 \\
\hline 18 & Downstream S1 & $0.002 *$ & 1.5 & 0.2 & 3.7 & 0.25 & 0.29 & E 0.01 & 0.076 & 23 & 7.63 & 115 \\
\hline 19 & Downstream S2 & $0^{*}$ & 1.8 & 0.2 & 5.3 & 0.14 & 0.15 & 0.06 & 0.026 & 54 & 7.75 & 163 \\
\hline 20 & Downstream B1 & $0^{*}$ & 1.6 & $0.002 *$ & 4.3 & 0.18 & 0.15 & E 0.02 & 0.02 & 66 & 7.57 & 181 \\
\hline 21 & Downstream B2 & 0.02 & 2.6 & $0.007 *$ & 4.8 & 0.45 & 0.4 & E 0.02 & $0.004 *$ & 96 & 7.54 & 276 \\
\hline 22 & Confluence S1 & $0^{*}$ & 1.9 & 0.2 & 4.9 & 0.29 & 0.31 & 0.06 & 0.03 & 94 & 7.87 & 148 \\
\hline 23 & Confluence S2 & $0.005^{*}$ & 2.3 & 0.2 & 6.8 & 0.12 & 0.15 & $0^{*}$ & 0.028 & 70 & 8.1 & 201 \\
\hline 24 & Confluence B1 & $0.008^{*}$ & 2 & 0.2 & 4.7 & 0.31 & 0.28 & E 0.04 & 0* & 66 & 8 & 218 \\
\hline 25 & Confluence B2 & 0.02 & 2.9 & 0.3 & 5 & 0.08 & 0.06 & $0 *$ & $0 *$ & 86 & 7.44 & 263 \\
\hline 26 & Ephemeral S1 & $0.007^{*}$ & 2.7 & 0.2 & 2.2 & 0.77 & 0.81 & $0 *$ & 0.062 & 131 & 7.16 & 313 \\
\hline 27 & Ephemeral S2 & 0.02 & 3.9 & 0.2 & 3.1 & 0.65 & 0.69 & $0^{*}$ & 0.03 & 167 & 7.48 & 394 \\
\hline $5 \mathrm{~B}$ & Ephemeral ISCO & $0^{*}$ & 3 & 0.9 & 2.6 & 0.51 & 0.59 & E 0.03 & -- & -- & 7.79 & 339 \\
\hline-- & Reporting limit & -- & 0.5 & 0.1 & 0.5 & 0.05 & 0.02 & 0.05 & 0.02 & -- & -- & -- \\
\hline-- & MDL & 0.015 & 0.15 & 0.042 & 0.032 & 0.02 & 0.004 & 0.01 & 0.005 & -- & -- & -- \\
\hline-- & Method & EPA 300 & EPA 300 & EPA 300 & EPA 300 & EPA 353.2 & EPA 300 & EPA 351.2 & APHA 4,500 & -- & -- & -- \\
\hline
\end{tabular}


Table 2. Potential nutrient source and stream sample $\delta^{15} \mathrm{~N}-\mathrm{NO}_{3}$ and $\delta^{18} 0-\mathrm{NO}_{3}$ values for sites in the Big Creek watershed.

[Source samples are shaded. $\delta$, delta; \%o, per mil; --, $\mathrm{NO}_{3}$ concentration insufficient to obtain isotope ratio; CAFO, concentrated animal feeding operation; $\mathrm{S}$, samples collected after rainfall; B, samples collected during base-flow conditions; ISCO, sample collected using ISCO autosampler]

\begin{tabular}{|c|c|c|c|c|}
\hline $\begin{array}{c}\text { Site } \\
\text { identifier }\end{array}$ & Sample name & $\begin{array}{l}\text { Sampling } \\
\text { date }\end{array}$ & $\begin{array}{l}\delta^{15 N} \\
(\% 0)\end{array}$ & $\begin{array}{l}\delta^{180} \\
(\% 0)\end{array}$ \\
\hline $1 \mathrm{~A}$ & Old Savoy lagoon & $4 / 18 / 16$ & 4.8 & 59.1 \\
\hline $1 \mathrm{~B}$ & Fresh Savoy lagoon & $8 / 26 / 16$ & -- & -- \\
\hline 2 & Hog manure & $8 / 26 / 16$ & -2.8 & 16.1 \\
\hline 3 & Fresh cow manure & $8 / 30 / 16$ & -- & -- \\
\hline 4 & Chicken litter & $8 / 18 / 16$ & 54.8 & 37.8 \\
\hline 6 & CAFO solids pond & $5 / 2 / 16$ & 4.2 & -7.2 \\
\hline 7 & CAFO liquids pond & $5 / 2 / 16$ & -- & -- \\
\hline 8 & Old cow manure & $8 / 30 / 16$ & 20.2 & 39.7 \\
\hline 9 & Inorganic fertilizer & $10 / 2 / 17$ & 14.4 & 24.8 \\
\hline 10 & Septic effluent & $9 / 23 / 17$ & 18.7 & 2.2 \\
\hline 11 & Field 1 runoff & $5 / 1 / 17$ & -3.0 & 32.8 \\
\hline 12 & Field $5 \mathrm{~A}$ runoff & $5 / 1 / 17$ & 0.2 & 34.2 \\
\hline 13 & Field 12 runoff & $5 / 1 / 17$ & -3.2 & 38.9 \\
\hline 32 & Parking lot runoff & $11 / 15 / 17$ & -15.4 & 56.1 \\
\hline 14 & Upstream S1 & $3 / 30 / 17$ & -0.2 & 1.1 \\
\hline 15 & Upstream S2 & $4 / 17 / 17$ & 0.2 & 9.1 \\
\hline 16 & Upstream B1 & $7 / 17 / 17$ & 0.2 & 2.2 \\
\hline 17 & Upstream B2 & $9 / 23 / 17$ & 3.8 & 7.8 \\
\hline 18 & Downstream S1 & $3 / 30 / 17$ & 1.4 & 1.1 \\
\hline 19 & Downstream S2 & $4 / 17 / 17$ & 3.5 & 3.3 \\
\hline 20 & Downstream B1 & $7 / 17 / 17$ & 5.0 & 2.3 \\
\hline 21 & Downstream B2 & $9 / 23 / 17$ & 6.7 & 1.6 \\
\hline 22 & Confluence S1 & $3 / 30 / 17$ & 3.1 & 2.4 \\
\hline 23 & Confluence S2 & $4 / 17 / 17$ & 3.3 & 4.9 \\
\hline 24 & Confluence B1 & $7 / 17 / 17$ & 3.8 & 3.0 \\
\hline 25 & Confluence B2 & $9 / 23 / 17$ & 4.9 & -2.2 \\
\hline 26 & Ephemeral S1 & $3 / 30 / 17$ & 0.7 & -0.7 \\
\hline 27 & Ephemeral S2 & $4 / 17 / 17$ & 2.1 & -0.7 \\
\hline $5 \mathrm{~A}$ & Ephemeral instream & $5 / 2 / 16$ & -3.4 & 2.4 \\
\hline $5 \mathrm{~B}$ & Ephemeral ISCO & $5 / 2 / 16$ & 0.5 & -7.6 \\
\hline
\end{tabular}

Manure $\delta^{15} \mathrm{~N}-\mathrm{NO}_{3}$ values varied widely but exhibited a smaller range of $\delta^{18} \mathrm{O}-\mathrm{NO}_{3}$ values (fig. 2). Chicken litter and old cow manure nitrate is most likely undergoing denitrification in situ as indicated by increased $\delta^{15} \mathrm{~N}^{-\mathrm{NO}_{3}}$ and $\delta^{18} \mathrm{O}-\mathrm{NO}_{3}$ when compared to referenced manure ranges. The septic system sample plots with a relatively heavy $\delta^{15} \mathrm{~N}_{-} \mathrm{NO}_{3}$, indicative of denitrification. Denitrification enriches $\mathrm{NO}_{3}$ $\delta^{18} \mathrm{O}: \delta^{15} \mathrm{~N}$ by a $1: 2$ ratio (Böttcher and others, 1990). The old cow manure $\delta^{15} \mathrm{~N}-\mathrm{NO}_{3}$ and $\delta^{18} \mathrm{O}-\mathrm{NO}_{3}$ values may also indicate nitrification involving waters that have been highly evaporated, resulting in relatively enriched $\delta^{18} \mathrm{O}-\mathrm{NO}_{3}$ available for microbial processing (Kendall and Caldwell, 1998). Two oxygen atoms from water are incorporated into $\mathrm{NO}_{3}$ produced during nitrification (Hollocher, 1984). Runoff samples exhibited light (depleted) $\delta^{15} \mathrm{~N}-\mathrm{NO}_{3}$ values ranging from -15.4 to $0.2 \%$ and heavy $\delta^{18} \mathrm{O}-\mathrm{NO}_{3}$ values ranging from 32.8 to $56.1 \%$, indicative of potential atmospheric deposition, oxygen-exchange effects, or nitrification using a highly evaporated water source.

Soil $\delta^{15} \mathrm{~N}-\mathrm{NO}_{3}$ and $\delta^{18} \mathrm{O}-\mathrm{NO}_{3}$ values were calculated from $\delta^{15} \mathrm{~N}-\mathrm{N}$ values measured by Fields and Halihan (2016). The $\delta^{18} \mathrm{O}$ of $\mathrm{NO}_{3}$ produced by nitrification of nitrogen was estimated using measured $\delta^{18} \mathrm{O}-\mathrm{H}_{2} \mathrm{O}$ values of Big Creek stream samples (-6.68 to $-4.96 \%$ ) and atmospheric $\mathrm{O}_{2}$ of 23.5\% (Kroopnick and Craig, 1972). Possible $\delta^{15} \mathrm{~N}^{-\mathrm{NO}_{3}}$ fractionation in soil was accounted for by adding a $1 \%$ buffer to the range of $\delta^{15} \mathrm{~N}-\mathrm{N}$ values measured by Fields and Halihan (2016). Estimates of $\delta^{15} \mathrm{~N}-\mathrm{NO}_{3}$ and $\delta^{18} \mathrm{O}-\mathrm{NO}_{3}$ produced by nitrification of nitrogen stored in soils in the watershed range from 2.8 to $7.6 \%{ }_{0} \delta^{15} \mathrm{~N}-\mathrm{NO}_{3}$ and 3.4 to $4.8 \%{ }^{18} \mathrm{O}-\mathrm{NO}_{3}$.

Fresh and old cow manure were compared to assess differences due to age. Fresh cow manure did not contain sufficient nitrate to obtain isotopic ratios. Fresh manure had higher ammonia, bromide, chloride, and fluoride concentrations compared with old manure, consistent with ongoing geochemical processing of cow manure in the field. In order to determine the effects of long holding times of the CAFO waste pond samples, the old and fresh Savoy lagoon samples were compared. The more recent (fresh) Savoy lagoon sample (1B) did not contain sufficient nitrate to determine isotopic ratios. Sample 1B had lower ammonia and higher chloride, nitrate plus nitrite, and sulfate $\left(\mathrm{SO}_{4}\right)$ concentrations compared with sample 1A (Old Savoy lagoon). Analyte concentrations of sample 1A, along with samples from the CAFO waste ponds, should be regarded as potentially less accurate due to long sample holding times.

\section{Nutrient Dynamics in the Big Creek Watershed}

The lack of spatial and temporal variance combined with the limited number of stream and source samples gives only a snapshot of nutrient dynamics in the Big Creek watershed. Stream samples contained little ammonia (range of 0 to 0.06 $\mathrm{mg} / \mathrm{L}$ ) and slightly more nitrate (range of 0.05 to $0.81 \mathrm{mg} / \mathrm{L}$ ) (table 1). Ephemeral stream samples contained higher nitrate concentrations compared with other stream sites. A Wilcoxon Rank Sum test was conducted with a 95 percent confidence interval for nitrate concentrations between the upstream and downstream sites. No statistically significant difference was observed, suggesting that either little nitrogen was added or that nitrogen inputs and removal were roughly balanced. 
Stream sample $\delta^{15} \mathrm{~N}-\mathrm{NO}_{3}$ and $\delta^{18} \mathrm{O}-\mathrm{NO}_{3}$ values are shown on figure 2 and in table 2. Big Creek stream sample values ranged from -3.4 to $6.7 \%{ }^{15} \mathrm{~N}^{-\mathrm{NO}_{3}}$ and -7.6 to $9.1 \% \delta^{18} \mathrm{O}-\mathrm{NO}_{3}$. These ranges overlap values expected from nitrification of nitrogen stored in soils in the watershed, as well as isotopic ranges documented in other studies of $\mathrm{NO}_{3}$ in manure and septic waste, and $\mathrm{NO}_{3}$ produced by nitrification of $\mathrm{NH}_{4}$ in fertilizer and precipitation (Böttcher and others, 1990; Kendall, 1998; Thomas, 2000). The CAFO solids pond $\delta^{15} \mathrm{~N}^{-\mathrm{NO}_{3}}$ and $\delta^{18} \mathrm{O}-\mathrm{NO}_{3}$ values were similar, but not identical to stream sample values.

Wilcoxon Rank Sum tests were conducted with a 95 percent confidence interval to compare $\delta^{15} \mathrm{~N}_{-} \mathrm{NO}_{3}$ and $\delta^{18} \mathrm{O}-\mathrm{NO}_{3}$ values among sites. In Big Creek, $\delta^{15} \mathrm{~N}-\mathrm{NO}_{3}$ was found to be statistically higher (more enriched) at the downstream site compared with the upstream site. Downstream $\delta^{15} \mathrm{~N}^{-\mathrm{NO}_{3}}$ was statistically more enriched than ephemeral $\delta^{15} \mathrm{~N}-\mathrm{NO}_{3}$, and confluence $\delta^{15} \mathrm{~N}^{-\mathrm{NO}_{3}}$ was statistically more enriched than both upstream $\delta^{15} \mathrm{~N}^{-\mathrm{NO}_{3}}$ and ephemeral $\delta^{15} \mathrm{~N}^{-\mathrm{NO}_{3}}$ (fig. 3). Whereas $\delta^{15} \mathrm{~N}^{-\mathrm{NO}_{3}}$ increased downstream, no statistical difference was determined for $\delta^{18} \mathrm{O}-\mathrm{NO}_{3}$, which implies that denitrification is likely not occurring in Big Creek between these sites and a source input with a more enriched $\delta^{15} \mathrm{~N}$ is potentially responsible for the elevated $\delta^{15} \mathrm{~N}$ between the sites. Nitrification of stream sediment nitrogen along the upstream to downstream reach of Big Creek may explain the decoupling of $\delta^{15} \mathrm{~N}$ and $\delta^{18} \mathrm{O}$ signatures; such nitrification could obfuscate any isotopic indication of denitrification along the reach. Coupling of denitrification in the water-sediment interface and growth of algal biomass, causing enrichment of $\delta^{15} \mathrm{~N}$ in residual nitrate, could also be responsible for the increased $\delta^{15} \mathrm{~N}_{-} \mathrm{NO}_{3}$ in Big Creek (Ford and others, 2015).
A plot of $\delta^{15} \mathrm{~N}-\mathrm{NO}_{3}$ and $1 / \mathrm{NO}_{3}$ concentration can indicate mixing of two sources with different $\delta^{15} \mathrm{~N}^{-\mathrm{NO}_{3}}$ values (Kendall, 1998). Isotopic ratios were plotted separately for individual stream sites and for all stream samples combined. When the stream sites were plotted together, stream samples showed no evidence of mixing. However, plotted as individual stream sites, both the upstream and confluence $\delta^{15} \mathrm{~N}^{-\mathrm{NO}_{3}}$ versus $1 / \mathrm{NO}_{3}$ plots were linear. Figure 4 shows a plot of $\delta^{15} \mathrm{~N}^{-N_{3}} \mathrm{O}_{3}$ versus $1 / \mathrm{NO}_{3}$ concentration at the upstream and confluence sites along with potential nutrient sources. The linear trends may indicate mixing of two sources for stream nitrate at the upstream and confluence sites but are likely an artifact of the small sample population size and relative values.

Stream samples show markedly different $\delta^{15} \mathrm{~N}-\mathrm{NO}_{3}$ and $\delta^{18} \mathrm{O}-\mathrm{NO}_{3}$ values when compared with those from sources sampled - chicken litter, cow manure, field runoff, parking lot runoff, and septic effluent. As such, stream $\delta^{15} \mathrm{~N}^{-\mathrm{NO}_{3}}$ and $\delta^{18} \mathrm{O}-\mathrm{NO}_{3}$ cannot be explained by simple, direct input of any one of these potential sources to the stream. If these sources are responsible for a considerable part of the stream nitrate load, then modification of isotopic composition by mixing or by fractionation/processing must be inferred. The nitrate isotope data are most consistent with an interpretation of stream nitrate being derived from nitrate stored in soils or from manure or septic sources not represented by the limited number of samples collected for this study. Soil nitrate can arise from multiple sources, including nitrogen-fixing plants, animal waste, applied waste effluent, and inorganic fertilizer.

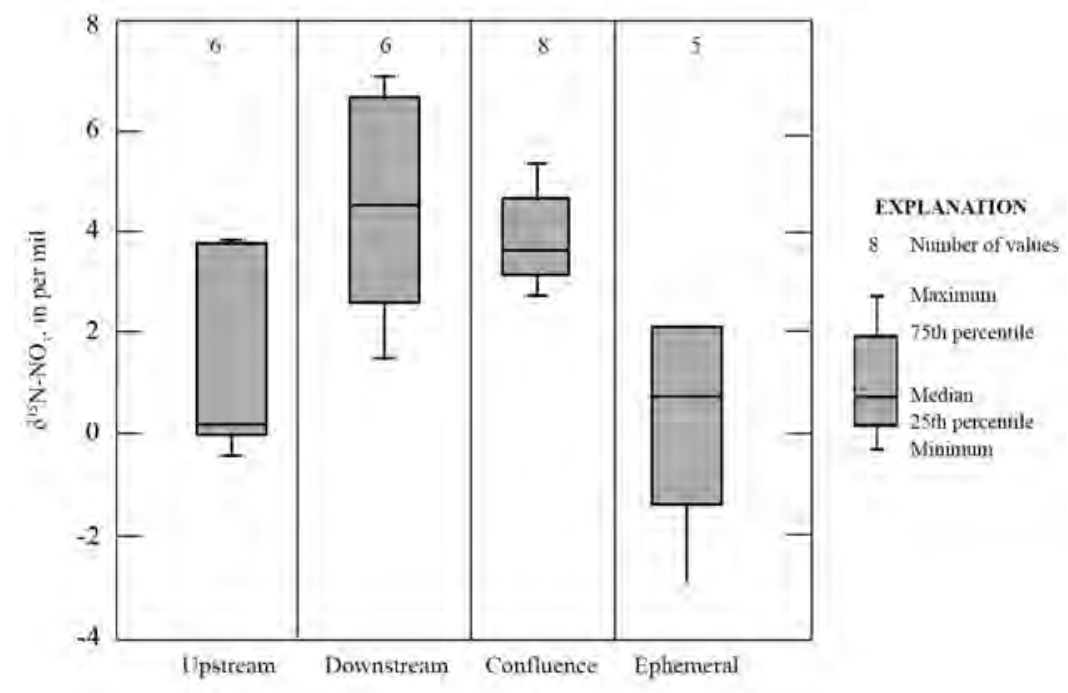

Figure 3. Stream sample $\delta^{15} \mathrm{~N}^{-\mathrm{NO}_{3}}$ at the upstream, downstream, confluence, and ephemeral sites in the Big Creek watershed. 


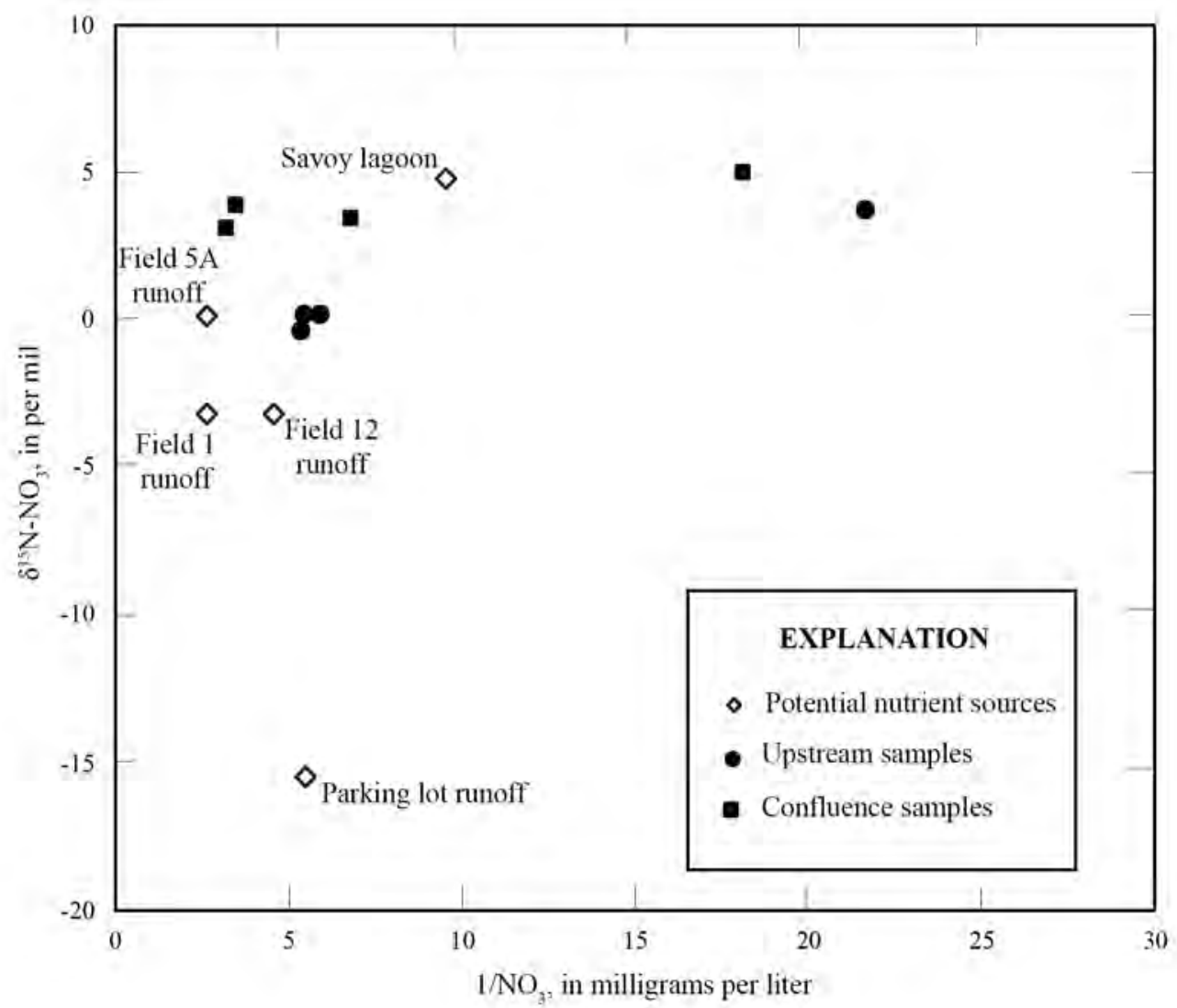

Figure 4. Potential nutrient source and stream sample $\delta^{15} \mathrm{~N}-\mathrm{NO}_{3}$ versus $1 / \mathrm{NO}_{3}$ concentration at the upstream and confluence sites on Big Creek.

\section{Conclusions}

The presence of karst terrain with complex groundwater-surface-water connections combined with multiple potential nutrient sources in the Big Creek watershed complicates the discrimination of nutrient sources and the understanding of nutrient dynamics. In transport from source to stream, ammonia from various potential sources is undergoing nitrification as evidenced by ranges of source ammonia ( 0.11 to $1,040 \mathrm{mg} / \mathrm{L}$ ) and nitrate concentrations ( 0 to $0.38 \mathrm{mg} / \mathrm{L}$ ), and stream ammonia ( 0 to $0.06 \mathrm{mg} / \mathrm{L}$ ) and nitrate concentrations $(0.05$ to $0.81 \mathrm{mg} / \mathrm{L})$. Potential nutrient sources are undergoing numerous processes in situ that affect $\mathrm{NO}_{3}$ isotopic ratios - nitrification, denitrification, evaporation, and dilution.

Big Creek samples exhibit different $\delta^{15} \mathrm{~N}-\mathrm{NO}_{3}$ and $\delta^{18} \mathrm{O}-\mathrm{NO}_{3}$ values than those for chicken litter, cow manure, field runoff, parking lot runoff, and septic effluent, indicating that if these sources were contributing significantly to the stream nutrient load, the isotopic composition of these sources was modified by mixing or fractionation. Stream $\delta^{15} \mathrm{~N}^{-\mathrm{NO}_{3}}$ and $\delta^{18} \mathrm{O}-\mathrm{NO}_{3}$ values indicate input of an enriched $\delta^{15} \mathrm{~N}^{-\mathrm{NO}_{3}}$ source along Big Creek. Estimated soil $\delta^{15} \mathrm{~N}_{-} \mathrm{NO}_{3}$ and $\delta^{18} \mathrm{O}-\mathrm{NO}_{3}$ values $\left(2.8\right.$ to $7.6 \%$ o $\delta^{15} \mathrm{~N}^{-\mathrm{NO}_{3}}$ and 3.4 to $4.8 \%$ $\delta^{18} \mathrm{O}-\mathrm{NO}_{3}$ ) overlap stream $\delta^{15} \mathrm{~N}-\mathrm{NO}_{3}$ and $\delta^{18} \mathrm{O}-\mathrm{NO}_{3}$ values $\left(-3.4\right.$ to $6.7 \%$ o $\delta^{15} \mathrm{~N}^{-\mathrm{NO}_{3}}$ and -7.6 to $9.1 \%$ o $\left.\delta^{18} \mathrm{O}-\mathrm{NO}_{3}\right)$. Nitrate in Big Creek is in part derived from soils in the watershed. Septic or manure sources not represented in this study could also contribute nitrate to Big Creek.

\section{Acknowledgments}

This work was funded in part by the AWRC/USGS 104B Grant Program and their generous support was greatly appreciated. The authors would like to thank Dr. Van Brahana and James A. Kingsbury for their thoughtful and helpful reviews of this manuscript. Appreciation is also extended to Erik Pollock and Dr. Andrew Sharpley for their guidance and laboratory funding assistance. In addition, the authors want to thank Ron and Chris Thurston, the UA Swine Farm, the UA Broiler Research Unit, Lindsey Conaway and Barry Shaulis at the UASIL, Tim Glover, Keith Trost, Jennifer Purtle, Erin Scott, Brian Haggard, and the AWRC staff for their help in sample collection and analysis. Any use of trade, firm, or product names is for descriptive purposes only and does not imply endorsement by the U.S. Government. 


\section{References Cited}

BCRET, 2016, Big Creek Research and Extension Team Quarterly Report-January 2016 to March 2016, Demonstrating and monitoring the sustainable management of nutrients on C\&H Farm in Big Creek watershed: University of Arkansas Division of Agriculture, Research and Extension, Fayetteville, Ark., 76 p., http://bigcreekresearch.org/.

Böttcher, J., Strebel, O., Voerkelius, S., and Schmidt, H.L., 1990, Using isotope fractionation of nitrate-nitrogen and nitrate-oxygen for evaluation of microbial denitrification in a sandy aquifer: Journal of Hydrology, v. 114, p. 413-424.

Brahana, J.V., Ting, T.E., Al-Qinna, M., Murdoch, J.F., Davis, R.K., Laincz, J., Killingbeck, J.J., Szilvagyi, E., Doheny-Skubic, M., Chaubey, I., Hays, P.D., and Thomas, G., 2005, Quantification of hydrologic budget parameters for the vadose zone and epikarst in mantled karst, in Kuniansky, E.L., ed., U.S. Geological Survey Karst Interest Group Proceedings, Rapid City, South Dakota, September 12-15, 2005: U.S. Geological Survey Scientific Investigations Report 2005-5160, p. 144-152.

Chandler, A.K., and Ausbrooks, S.M., 2003 (revised 2015), Geologic map of the Mt. Judea quadrangle, Newton County, Arkansas: Arkansas Geological Survey Digital Geologic Quadrangle Map DGM-AR-00590, scale 1:24,000, 1 sheet.

Coplen, T.B., Qi, H., Révész, K., Casciotti, K., and Hannon, J.E., 2012, Determination of the $\delta^{15} \mathrm{~N}$ and $\delta^{18} \mathrm{O}$ of nitrate in water; RSIL lab code 2900, in Révész, K., and Coplen, T.B., eds., Methods of the Reston Stable Isotope Laboratory: U.S. Geological Survey Techniques and Methods, book 10, chap. 17, 35 p.

Fields, J., and Halihan, T., 2016, Electrical resistivity surveys of applied hog manure sites, Mount Judea, AR: Oklahoma State University, Boone Pickens School of Geology, 55 p.

Ford, W.I., Fox, J.F., Pollock, E., Rowe, H., and Chakraborty, S., 2015, Testing assumptions for nitrogen transformation in a low-gradient agricultural stream: Journal of Hydrology, v. 527, p. 908-922.

Hays, P.D., Knierim, K.J., Breaker, B., Westerman, D.A., and Clark, B.R., 2016, Hydrogeology and hydrologic conditions of the Ozark Plateaus aquifer system: U.S. Geological Survey Scientific Investigations Report 2016-5137, 61 p.

Hollocher, T.C., 1984, Source of the oxygen atoms of nitrate in the oxidation of nitrite by Nitrobacter agilis and evidence against a $\mathrm{P} / \mathrm{O} / \mathrm{N}$ anhydride mechanism in oxidative phosphorylation: Archives of Biochemistry and Biophysics, v. 233, no. 2, p. 721-727.
Imes, J.L., and Emmett, L.F., 1994, Geohydrology of the Ozark Plateaus aquifer system in parts of Missouri, Arkansas, Oklahoma, and Kansas: U.S. Geological Survey Professional Paper 1414-D, p. D1-D127.

Kendall, C., 1998, Tracing nitrogen sources and cycling in catchments, in Kendall, C., and McDonnell, J.J., eds., Isotope tracers in catchment hydrology: Amsterdam, Elsevier Science B.V., p. 519-576.

Kendall, C., and Caldwell, J.J., 1998, Fundamentals of isotope geochemistry, in Kendall, C., and McDonnell, J.J., eds., Isotope tracers in catchment hydrology: Amsterdam, Elsevier Science B.V., p. 51-86.

Kopp, J.F., and McKee, G.D., 1993, EPA Method 351.2, Revision 2.0-Determination of total kjeldahl nitrogen by semi-automated colorimetry, in Methods for chemical analysis of water and wastes: Washington, D.C., U.S. Environmental Protection Agency, 16 p.

Kroopnick, P.M., and Craig, H.C., 1972, Atmospheric oxygen-Isotopic composition and solubility fractionation: Science, v. 175, no. 4017, p. 54-55.

McIlvin, M.R., and Casciotti, K.L., 2011, Technical updates to the bacterial method for nitrate isotopic analyses: Analytical Chemistry, v. 83, no. 5, p. 1850-1856.

O’Dell, J., 1993, EPA Method 353.2, Revision 2.0Determination of nitrate-nitrite nitrogen by automated colorimetry, in Methods for chemical analysis of water and wastes: Washington, D.C., U.S. Environmental Protection Agency, 14 p.

Peterson, E.W., Davis, R.K., Brahana, J.V., and Orndorff, H.A., 2002, Movement of nitrate through regolith covered karst terrane, northwest Arkansas: Journal of Hydrology, v. 256, no. 1, p. 35-47.

Pfaff, J.D., 1993, EPA Method 300.0, Revision 2.1Determination of inorganic anions by ion chromatography, in Methods for chemical analysis of water and wastes: Washington, D.C., U.S. Environmental Protection Agency, 28 p.

Sharpley, A.N., Haggard, B.E., Berry, L., Brye, K., Burke, J., Daniels, M.B., Gbur, E., Glover, T., Hays, P., Kresse, T., and VanDevender, K.W., 2017, Nutrient concentrations in Big Creek correlate to regional watershed land use: Agricultural and Environmental Letters, v. 2, no. 1, 6 p.

Sigman, D.M., Casciotti, K.L., Andreani, M., Barford, C., Galanter, M., and Böhlke, J.K., 2001, A bacterial method for the nitrogen isotopic analysis of nitrate in seawater and freshwater: Analytical Chemistry, v. 73, no. 17, p. $4145-4153$. 
Sokolosky, K.R., 2019, Stable isotope and geochemical characterization of nutrient sources in the Big Creek watershed of northwest Arkansas: Fayetteville, University of Arkansas, Master's thesis, 63 p., 10 figs., 17 tables, https://scholarworks.uark.edu/etd/3400.
Thomas, M.A., 2000, The effect of residential development on ground-water quality near Detroit, Michigan: Journal of the American Water Resources Association, v. 36, p. $1023-1038$. 


\title{
Preliminary Analysis of Hydrologic and Geochemical Data to Guide Groundwater-Flow Model Development for Two Karst Aquifers in Colorado
}

\author{
By Connor P. Newman ${ }^{1}$ \\ 'U.S. Geological Survey, Denver Federal Center, MS 415, Denver, CO 80225. \\ (Email: cpnewman@usgs.gov)
}

\begin{abstract}
The Manitou Springs and Glenwood Springs aquifers, located on the eastern and western margins of the Colorado Rocky Mountains, respectively, are both hosted within carbonate rocks of Paleozoic age (Manitou Formation and Leadville Limestone, respectively). Both aquifers display karst features such as cave systems and discrete groundwater discharge points including flowing artesian wells and springs. Hydrologic data, including potentiometric-surface elevations (hydraulic heads) when paired with geochemical data, can provide insight into recharge processes and flow paths, both of which are used to build numerical groundwater-flow models. Analysis of hydraulic heads measured at flowing wells completed in the Manitou Springs aquifer indicates that groundwater flow originates as recharge in the western part of the Manitou Formation outcrop area and proceeds down-dip to the east within the Manitou Springs aquifer. Geochemical analyses of calcite and dolomite saturation indices and major ions support this conceptual understanding of flow-system orientation and indicate possible groundwater flow into the Manitou Springs aquifer from the underlying Pikes Peak Granite. Hydrologic and geochemical data used to develop the conceptual understanding of groundwater flow in the Manitou Springs aquifer can be used to form the basis for a planned numerical groundwater-flow model.

In contrast to the Manitou Springs aquifer, no recent hydraulic-head data are available for the Glenwood Springs aquifer, but geochemical data indicate the presence of two hot spring flow systems: one interacting with evaporite minerals such as gypsum and halite and the other having a dilute composition. These spring systems are also distinct spatially
\end{abstract}

from one another. Detailed groundwater-flow modeling of the Glenwood Springs aquifer would require substantially more hydrologic data because of the lack of hydraulic-head data.

\section{Introduction}

Karst aquifers are a substantial source of groundwater worldwide. Commonly, karst aquifers are highly permeable and provide good-quality drinking water but are susceptible to anthropogenic and natural contamination (Kalhor and others, 2019). Karst aquifers are generally formed by the dissolution of carbonate rocks with calcite and dolomite commonly being the primary rock-forming minerals. Because of their prevalence as domestic and industrial water sources, karst aquifers have been studied to understand recharge processes (Barbieri and others, 2005), groundwater flow paths and geochemical evolution (Ma and others, 2011; Yuan and others, 2017), and residence-time distributions (Toth and Katz, 2006). Various methods can be used to understand karst aquifers including geochemical sampling of discharge points and water-quality modeling (Plummer and others, 1990), tracer tests (Goldscheider and others, 2008), and groundwater-flow modeling (Ghasemizadeh and others, 2016).

The study described herein focuses on two karst aquifers in Colorado: the Manitou Springs aquifer and the Glenwood Springs aquifer (fig. 1). The purpose of the study was to provide examples of preliminary data-analysis techniques applicable to characterizing karst aquifers, with a focus on flow paths, identification of recharge areas, and quantification of residence times. For the Manitou Springs aquifer both hydrologic and geochemical data were used, whereas for the Glenwood Springs aquifer only geochemical data analysis was applied because of the lack of appropriate hydrologic data. 


\section{Study Sites}

The Manitou Springs aquifer is located on the eastern side of the Rocky Mountains along the Colorado Front Range, coincident with the town of Manitou Springs (fig. 1). The aquifer is primarily hosted within the Late Cambrian- to Early Ordovician-age Manitou Formation (limestone and dolomite), with some storage in the underlying Late Cambrian-age Sawatch Quartzite and overlying Mississippian-age Leadville Limestone (Mayo and Muller, 1997; Maslyn and others, 2017). The entire stratigraphic sequence dips to the southeast and is unconformably deposited on the Proterozoic-age Pikes Peak Granite (Mayo and Muller, 1997; Keller and others, 2005; Shomaker and Associates, 2011). Solution caves are found in the area topographically upgradient of most current and historical springs, and include the commercially operated Cave of the Winds (Maslyn and others, 2017).
Historically, the area had numerous freely flowing springs, many of which have been sampled for water quality (fig. 1; Mayo and Muller, 1997; Shomaker and Associates, 2011). Over time however, many of the original spring locations have been urbanized, diverting or otherwise interrupting the springflow. Additionally, numerous wells have been installed in the aquifer since the early 20th century, likely increasing the total discharge and lowering the potentiometric surface below pre-development levels (Shomaker and Associates, 2011). As a result, the springs currently found throughout the town of Manitou Springs are more strictly classified as flowing artesian wells and not true bedrock springs. The term "spring" is used herein when referring to the Manitou Springs aquifer, for consistency with historical names. Springs are grouped geographically for this analysis into the western, northern, central, and eastern discharge areas (fig. 1).

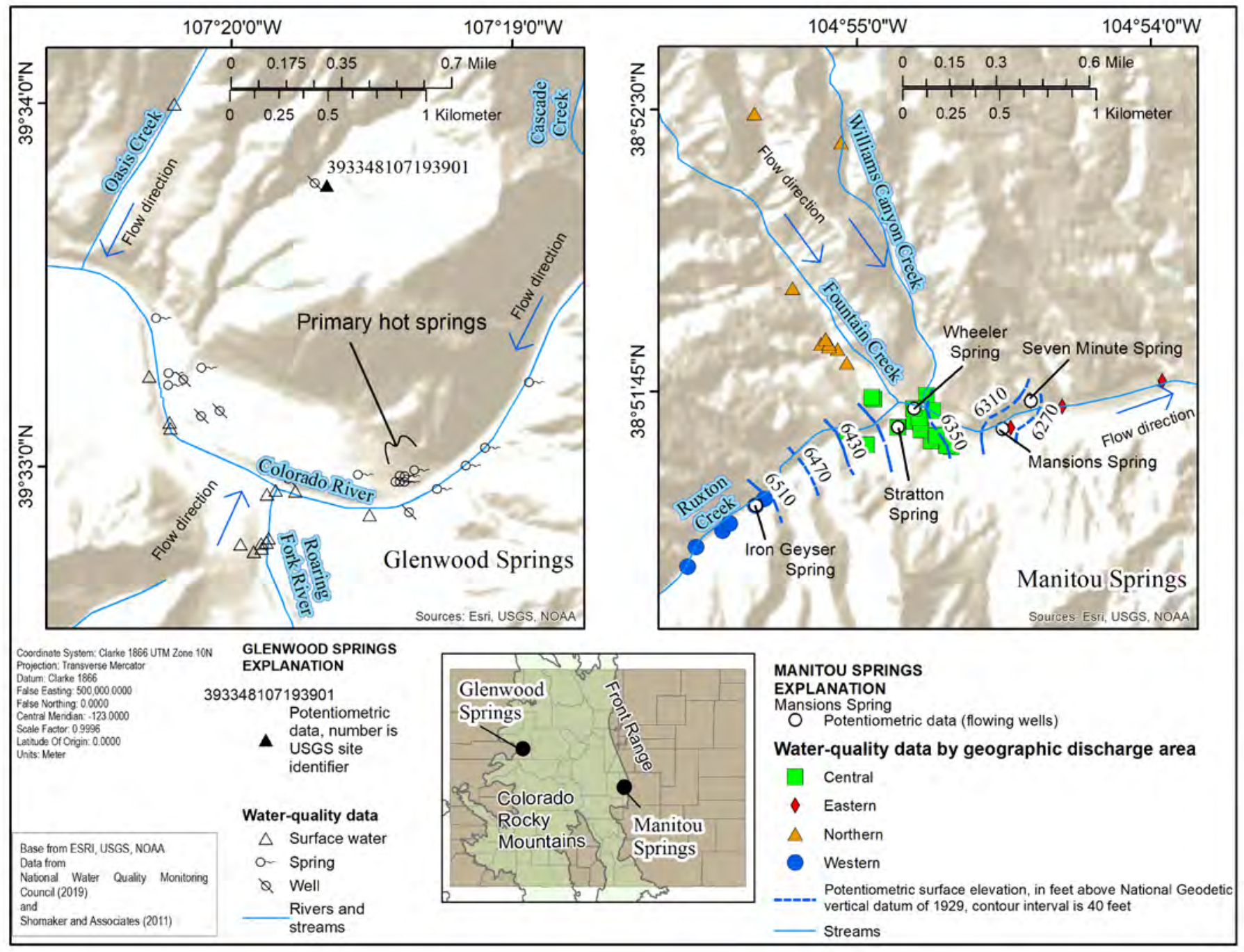

Figure 1. Location of potentiometric and water-quality data monitoring network sites for the Glenwood Springs and Manitou Springs aquifers study areas, Colorado. 
The Glenwood Springs aquifer is coincident with the town of Glenwood Springs, on the western slope of the Colorado Rocky Mountains (fig. 1). The aquifer is primarily contained within the Mississippian-age Leadville Limestone, which is regionally extensive in Colorado, as well as Quaternary-age alluvium (Geldon, 1989). The Pennsylvanian-age Eagle Valley Evaporite, which stratigraphically overlies the Leadville Limestone, is also an important hydrostratigraphic unit in the region (Kirkham and others, 2001), although it is not a primary aquifer because of the high salinity of produced water. Similar to the Manitou Springs aquifer, navigable cave systems exist in the area and include the commercially operated Glenwood Caverns (Maslyn and others, 2017).

Numerous hot springs are located along the Colorado River in the vicinity of the town of Glenwood Springs, several of which are operated commercially as hot spring swimming pools. The spring locations have been previously interpreted as the termination and discharge area of regional groundwater flow paths originating to the south in the Eagle Valley Evaporite (Maslyn and others, 2017) and to the north in the Leadville Limestone (Geldon, 1989). The hot springs have also been the subject of a variety of geochemical analyses because of their importance in imparting solute loads to the Colorado River (Eisenhauer, 1983, 1986; URS Corporation, 1983, unpub. data).

\section{Data and Methods}

Data used in a preliminary analysis of the Manitou Springs and Glenwood Springs aquifers are distinctly different, thus, different methods were used for each aquifer. For the Manitou Springs aquifer, both potentiometric and geochemical data were used, whereas for the Glenwood Springs aquifer only geochemical data analysis was applied.

\section{Hydrologic and Geochemical Data}

Available hydrologic data for the Manitou Springs aquifer include pressure-transducer measurements from flowing wells. Available groundwater geochemical data include analyses of major ions, trace elements, stable isotopes, and dissolved noble gases collected from both flowing wells and bedrock springs. All data for the Manitou Springs aquifer were supplied by the Manitou Mineral Springs Foundation, as obtained from current monitoring and reports by Mayo and Muller (1997) and Shomaker and Associates (2011). Water-quality data for flowing wells and bedrock springs were combined for geochemical analyses. This analysis focused on major-ion data, and stable isotope and noble gas data were not used, though they may provide further utility in future modeling efforts.

Hydrologic data for the Glenwood Springs aquifer are generally lacking as essentially no synoptic measurements of hydraulic heads are available. At one former U.S. Geological Survey well, hydraulic-head data were collected for the Leadville Limestone (fig. 1), and various wells were previously used in aquifer testing that intersected the hot spring hydrologic system (Geldon, 1989). However, previous data are insufficient for an aquifer-wide hydrologic analysis, and no recent hydraulic-head data (last measurement was in 1983) are available. Available geochemical data for the Glenwood Springs aquifer include water temperature, and geochemical analyses of major ions and trace elements in springwater, surface water, and groundwater samples that were collected over a period of nearly 50 years (1970s through 2019) in a non-synoptic manner. Glenwood Springs aquifer data were collected by various agencies and were obtained from the Water Quality Portal (National Water Quality Monitoring Council, 2019).

\section{Water-Level Modeling and Hydraulic Analysis}

A general hydraulic analysis (vertical gradients, flow directions) was conducted for the Manitou Springs aquifer, but appropriate hydrologic data are not available for the Glenwood Springs aquifer. Hydraulic head in a flowing well is considered representative of static conditions only when the well is shut in and not flowing (Cunningham and Schalk, 2011). However, flowing wells in the Manitou Springs area are used to support commercial enterprises and are not regularly shut in for pressure measurements such that measurements of truly static hydraulic conditions are relatively rare. Pressure-transducer data are available for five 
flowing wells in the Manitou Springs aquifer (fig. 1), each of which has a pressure transducer (collecting data on an hourly frequency) both at the wellhead and well bottom (well depths range from 283 to 400 feet) and designed to measure a head difference within the well. Although these wells are flowing, and therefore do not provide a true static-head measurement, the relation of transient-head measurements to one another do provide a basis for potentiometric-surface elevations (albeit not a steady-state surface). The wells are essentially pumped at a constant and low rate because they rarely (or never) reach true static conditions. Total hydraulic head in each flowing well was calculated as follows:

$$
h=(P \times 2.31)+h_{e}
$$

where

$h$ is total hydraulic head, in feet above datum,

$P \quad$ is pressure head measured by transducers, in pounds per square inch (psi),

2.31 is a conversion factor from psi to feet, and

$h_{e}$ is elevation head for the measurement point, in feet above datum.

Water-level modeling can be a useful tool for gaining a general understanding of aquifer stresses and the response of water levels to those stresses (Bakker and Schaars, 2019). Water-level models are commonly implemented using a transfer-function-noise (TFN) statistical approach, wherein the proportion of variance in observed water-level fluctuation can be attributed to specific stresses, such as pumping or climate. In this study, the Pastas package implemented in Python (Collenteur and others, 2019) was used to evaluate water-level changes in the Manitou Springs aquifer in comparison to climatic data (precipitation and evapotranspiration). Simulations included precipitation and evapotranspiration in a linear combination to represent net recharge. Daily climatic data for precipitation and grass reference evapotranspiration $\left(\mathrm{ET}_{\mathrm{O}}\right)$ were obtained using the Climate Engine online tool (Huntington and others, 2017).

\section{Aqueous Geochemistry and Mineral Equilibria}

The geochemistry of spring discharge and well water in karst aquifers can give insights into residence times, water-rock interactions, and recharge sources (Barbieri and others, 2005; Moral and others, 2008; Ma and others, 2011; Yuan and others, 2017). Specifically, dissolution of the rock-forming minerals dolomite and calcite, as well as accessory minerals such as gypsum, produces a specific water-quality signature. All three of these minerals are present in the study areas (Geldon, 1989; Keller and others, 2005; Maslyn and others, 2017). The dissolution of gypsum, calcite, and dolomite proceed respectively, according to Ma and others (2011), as follows:

$$
\begin{gathered}
\mathrm{CaSO}_{4} \cdot 2 \mathrm{H}_{2} \mathrm{O}+\mathrm{H}_{2} \mathrm{O} \leftrightarrow \mathrm{Ca}^{2+}+\mathrm{SO}_{4}^{2-}+3 \mathrm{H}_{2} \mathrm{O} \\
\mathrm{CaCO}_{3}+\mathrm{H}_{2} \mathrm{O}+\mathrm{CO}_{2} \leftrightarrow \mathrm{Ca}^{2+}+2 \mathrm{HCO}_{3}^{-} \\
\mathrm{CaMg}\left(\mathrm{CO}_{3}\right)_{2}+2 \mathrm{H}_{2} \mathrm{O}+2 \mathrm{CO}_{2} \leftrightarrow \mathrm{Ca}^{2+}+\mathrm{Mg}^{2+}+4 \mathrm{HCO}_{3}^{-}
\end{gathered}
$$

The concurrent dissolution of calcite and dolomite proceeds according to Ma and others (2011), as follows:

$$
\mathrm{CaCO}_{3}+\mathrm{CaMg}\left(\mathrm{CO}_{3}\right)_{2}+3 \mathrm{H}_{2} \mathrm{O}+3 \mathrm{CO}_{2} \leftrightarrow 2 \mathrm{Ca}^{2+}+\mathrm{Mg}^{2+}+6 \mathrm{HCO}_{3}^{-}
$$


The stoichiometry of these reactions can provide information on dominant geochemical processes when considered in conjunction with spring and groundwater-quality data. Specifically, the stoichiometric ratios of calcium to bicarbonate are 1:2 in calcite dissolution, 1:4 in pure dolomite dissolution, and 1:3 when dolomite and calcite dissolve concurrently. Similarly, the molar ratios of magnesium to bicarbonate are 1:4 in pure dolomite dissolution and 1:6 when dolomite and calcite dissolve concurrently. However, because calcium is also present in the gypsum dissolution reaction, the quantity of calcium attributable to only carbonate dissolution must be determined to calculate molar ratios involving only calcium. To facilitate this analysis, the molarity of sulfate in each water sample was subtracted from the calcium molarity because calcium and sulfate have a 1:1 ratio in gypsum dissolution (eq. 2). This calculation yields the excess calcium (the calcium that is in excess of gypsum dissolution and only attributable to carbonate dissolution), allowing for direct comparison with bicarbonate and magnesium molarities (Ma and others, 2011).

Geochemical modeling also can inform analyses of karst aquifers (Plummer and others, 1990; Toth and Katz, 2006). For this study, saturation indices (SIs) were evaluated for rock-forming minerals identified as likely present in the Manitou Springs aquifer (calcite and dolomite); all calculations used PHREEQC (Parkhurst and Appelo, 2013). For the Glenwood Springs aquifer, concentrations of various constituents were evaluated with respect to water temperature to inform an understanding of the source(s) of springflow.

\section{Preliminary Data Analysis of the Manitou Springs Aquifer}

The approximate potentiometric surface of the Manitou Springs aquifer indicates groundwater originates as recharge on the Manitou Formation outcrop area west of the town of Manitou Springs and flows to the east generally following the topographic gradient (fig. 1) and structural dip of the Manitou Formation. Although the flowing wells utilized by this analysis are not routinely shut in, the potentiometric surface developed from flowing-well pressure (hydraulic-head) data is consistent with both the topography and hydrostratigraphy of the area. These results indicate that pressures monitored in flowing wells can be useful in conceptualizing flow in confined aquifers, given some consideration as discussed in the following paragraphs.

Shut-in test results for Seven Minute Spring (see figure 1 for location), the only spring shut in to allow hydraulic heads to equilibrate, are shown on figure 2. Prior to initiation of the shut-in test, the vertical hydraulic gradient was upward from the base of the well to the surface. The vertical gradient reversed to downward upon initiation of shut-in conditions, with pressure at the surface surpassing pressure at the bottom of the well. Following the 24-hour shut-in period, the well was allowed to flow without restriction for 15 days. During this 15-day open-flow period, there was an upward vertical gradient, and pressures at the wellhead declined over time with respect to bottom pressures as the aquifer depressurized. Finally, at the end of the 15-day open-flow period, the well discharge was reduced by engineered piping and diversion, resulting in a final downward gradient. Results from this shut-in test indicate that potentiometric surfaces constructed using data from flowing wells (as on figure 1) warrant careful consideration. Given the agreement between hydrostratigraphic information and geochemical analyses (discussed below), it appears that hydraulic-head data from flowing wells can be of use in conceptualizing the hydrologic system and for recognizing discrete areas of groundwater discharge.

Results of water-level modeling for Seven Minute Spring and Mansions Spring are illustrated on figure 3. The hydraulic head in both locations appears to fluctuate on an annual basis, with the effect of other processes evident. For instance, a large departure from previous behavior is observed for Mansions Spring in late 2016, although the cause of this departure is not evident in the climatic dataset. Also illustrated on figure 3 are pie charts displaying the proportion of variance in hydraulic-head data explainable by net recharge. Variation in Seven Minute Spring is 48.4 percent explainable by net recharge, indicating that a simple model including only recharge processes can reasonably simulate groundwater dynamics in this area. Data from the shut-in test are excluded from the TFN analysis to remove possible confounding effects, but they could be included to gain a better understanding of the effect of discharge events on the system.

In contrast to Seven Minute Spring, none of the hydraulic-head variation in Mansions Spring can be attributed to net recharge, primarily because of the observations from 2015 and 2016 when hydraulic heads changed dramatically. These water-level modeling results are nevertheless useful for this location because they show that the TFN model (or a groundwater-flow model) would benefit from inclusion of additional processes in the vicinity of this well, such as the emplacement of production wells or other localized groundwater sinks.

Both TFN models include only net recharge as a potentially controlling factor. Additional factors that could be included to potentially explain more of the signal are streamflow and pumping (Collenteur and others, 2019). Although the Manitou Springs aquifer is confined, streamflow infiltration has been hypothesized as a source of recharge (Shomaker and Associates, 2011). Water-level modeling combined with streamflow gain-loss analysis for creeks in the area (fig. 1) will therefore, be important to incorporate in further analysis and groundwater-flow modeling. 


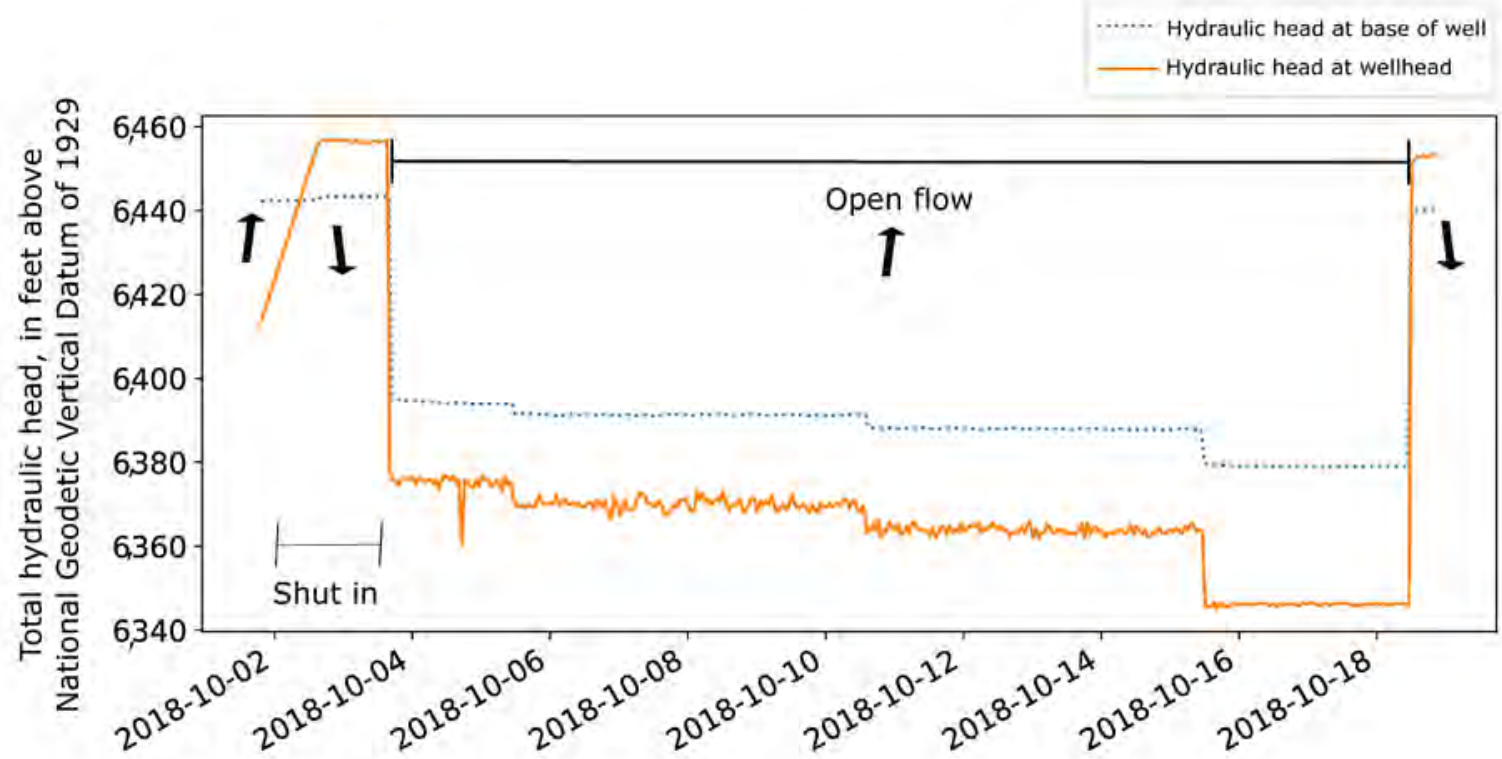

Figure 2. Record of total hydraulic head in Seven Minute Spring during the October 2018 shut-in test. Arrows represent direction of the vertical hydraulic gradient with upward arrows representing flow from the base of the well to the surface (wellhead) and downward arrows representing the opposite downward gradient. Data furnished by Manitou Mineral Springs Foundation.
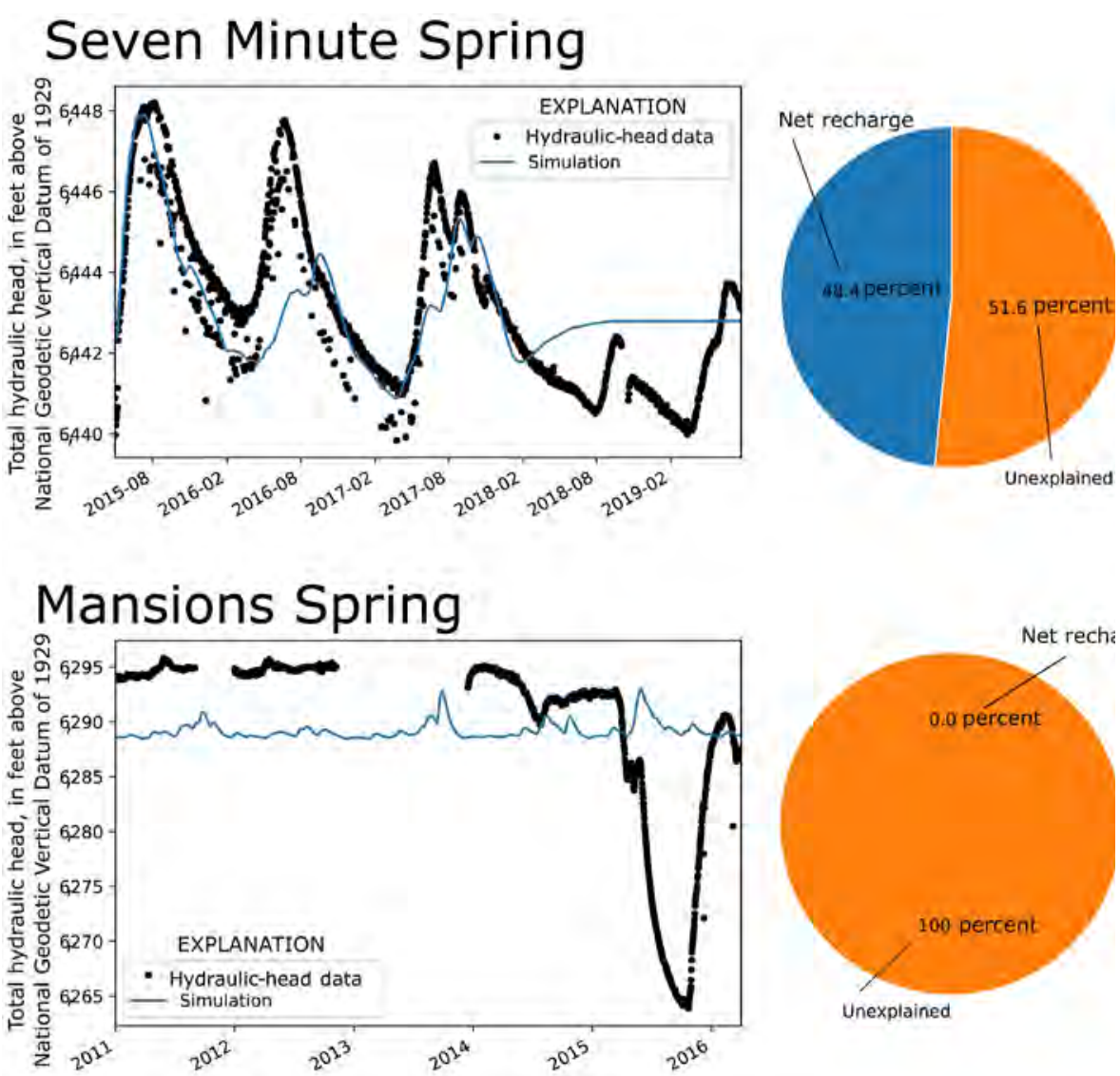

Figure 3. Results of transfer-function-noise modeling for Seven Minute Spring and Mansions Spring, including observed and simulated hydraulic-head elevations and pie charts of percent variance, explained by the combination of precipitation and evapotranspiration (net recharge). Data furnished by Manitou Mineral Springs Foundation. 
Geochemical data from the Manitou Springs aquifer support the interpretations of groundwater-flow directions from potentiometric-surface data and indicate that groundwater moving downgradient from west to east becomes progressively more saturated with respect to the carbonate minerals calcite and dolomite (fig. 4). Specifically, the western springs are generally undersaturated with respect to calcite and dolomite, whereas the central and eastern springs are more commonly supersaturated with respect to calcite and dolomite. However, water sample saturation index (SI) values do not lie on the congruent (1:1) line for calcite and dolomite dissolution or precipitation (fig. 4), and the trend of the SI values indicates that dolomite might be preferentially dissolved over calcite. This observation contrasts with dolomite and calcite dissolution kinetics wherein calcite typically dissolves more rapidly than dolomite (Appelo and Postma, 2005, p. 215). The departure from theoretical predictions may be caused by the mineralogic character of the Manitou Formation and the availability of each mineral. The analysis of calcite and dolomite SIs indicates that groundwater could have a substantial residence time or that rapid reaction rates predominate because water chemistry transitions from undersaturated to supersaturated with respect to calcite and dolomite over a relatively short land-surface distance (about 4,900 feet [1,500 meters]) from the western to eastern springs.

Major-ion analysis supports the concurrent dissolution of calcite and dolomite (fig. 5). Ratios of excess calcium to bicarbonate, magnesium to bicarbonate, and excess calcium to magnesium all are consistent with carbonate mineral dissolution, with some group-specific patterns emerging. The western springs tend to have bicarbonate in excess of that explainable by carbonate dissolution, given that their compositions lie above the mineral-specific dissolution lines illustrated on figure 5 (upper panels). Mayo and Muller (1997) hypothesized a carbon-rich gas source in the area of the western springs, which could explain the excess bicarbonate. Also, the compositions of the central springs tend to plot between the western and northern springs, consistent with groundwater flow originating in the western and northern areas and then mixing downgradient (the central springs are mixtures of groundwater that originated in the upgradient areas). The major-ion compositions also indicate that there could be an external source of sodium to the system because sodium concentrations in all springs plot above a stoichiometric halite dissolution line (fig. 5). Albite $\left(\mathrm{NaAlSi}_{3} \mathrm{O}_{8}\right)$ dissolution in the Pikes Peak Granite could explain the excess sodium as was hypothesized by Luiszer (1997) and Shomaker and Associates (2011) and noted in other karst systems (Barbieri and others, 2005; Yuan and others, 2017).

\section{Preliminary Data Analysis of the Glenwood Springs Aquifer}

Unlike the Manitou Springs aquifer, no detailed or synoptic water levels are available to create a potentiometric-surface map for the Glenwood Springs aquifer. Geochemical data are available however, for springs, surface water, and wells in the area, and these data can be used in lieu of direct hydrologic observation to conceptualize the hydrologic system and to provide insight on where future observations could be focused.

The geochemistry of the Glenwood Springs hot springs lends insight into the aquifer materials along the flow path(s). A comparison of major-ion concentrations and temperature (fig. 6) indicates that two distinct flow systems could be present in the area. One group of springs displays elevated temperatures and concentrations of calcium, sulfate, sodium, and chloride, and a second group of springs displays elevated temperatures but relatively dilute major-ion concentrations. The springs with elevated constituent concentrations indicate interaction with evaporite minerals such as gypsum and halite, consistent with conceptual models described by Kirkham and others (2001) and Maslyn and others (2017). The relatively dilute hot springs are downstream from the town of Glenwood Springs outside the map extent of figure 1 and may represent a shorter flow path (less time for water-rock interaction), a flow path through a different hydrostratigraphic sequence, or perhaps the influence of shallow groundwater-surface-water interaction on spring chemistry.

In contrast to the geochemistry of the two hot spring systems, all samples collected from surface water and groundwater are relatively cold and dilute (fig. 6) with the exception of iron (discussed below). Although the dilute nature of surface waters is not necessarily surprising, the lack of geothermal water in sampled wells indicates that no flow paths within the hot spring hydrologic systems are intersected by the sampled wells. Data from additional wells that intersect the systems at various points would likely be needed to complete a more detailed hydrologic analysis of the hot spring systems.

In comparison to surface water, hot spring water and groundwater are both dilute with respect to iron, and a distinct maximum in iron concentration is evident within a specific range of temperature values. Samples with high iron concentrations also tend to have elevated manganese concentrations (not shown on figure 6), possibly indicating oxidation-reduction (redox) controls on these metals in surface water. 


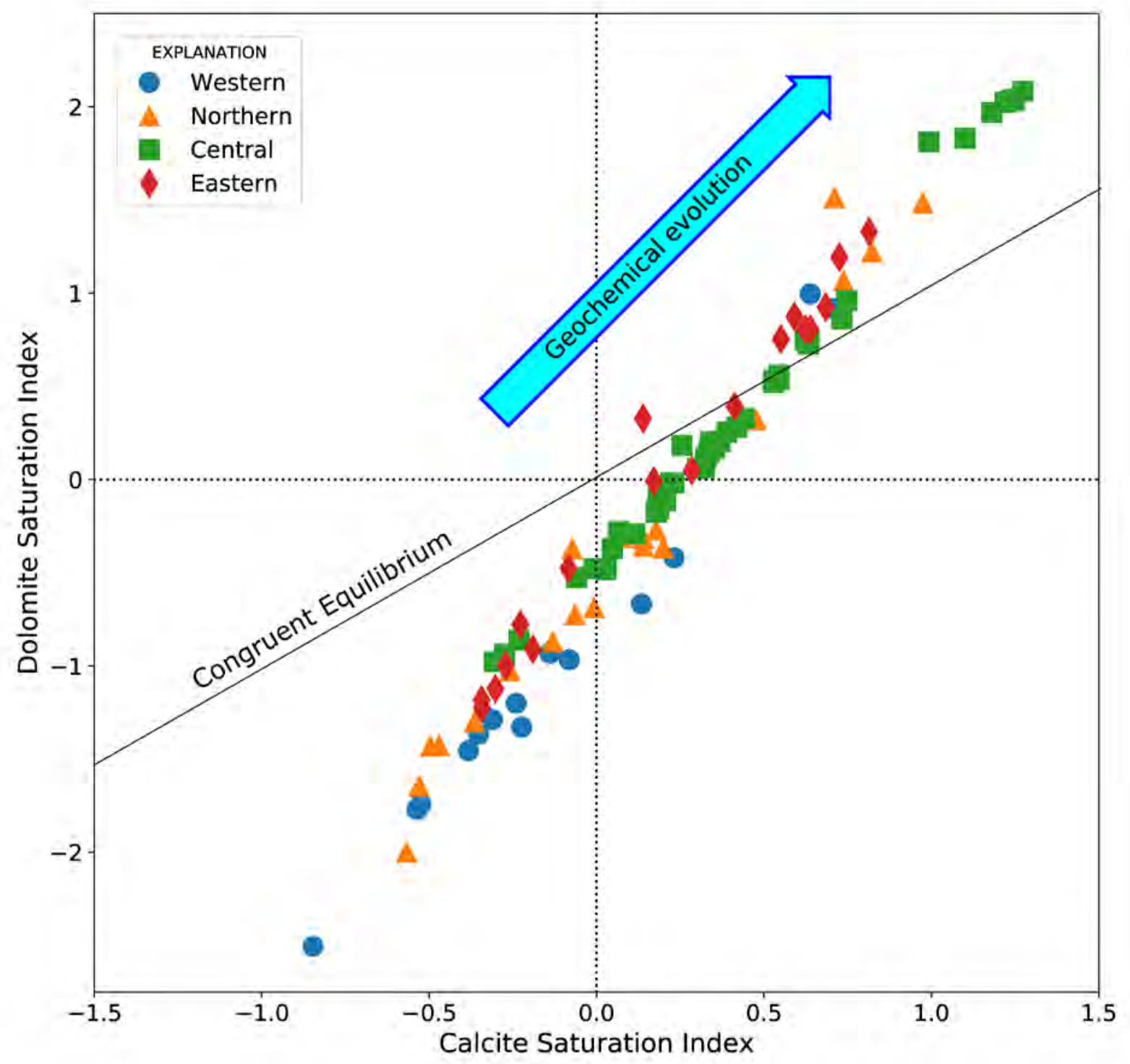

Figure 4. Dolomite and calcite saturation indices (SI) for geographically grouped flowing wells and springs in the Manitou Springs aquifer. The line marked congruent equilibrium displays the trajectory if dolomite and calcite were being dissolved or precipitated in a congruent manner (1:1 ratio). 

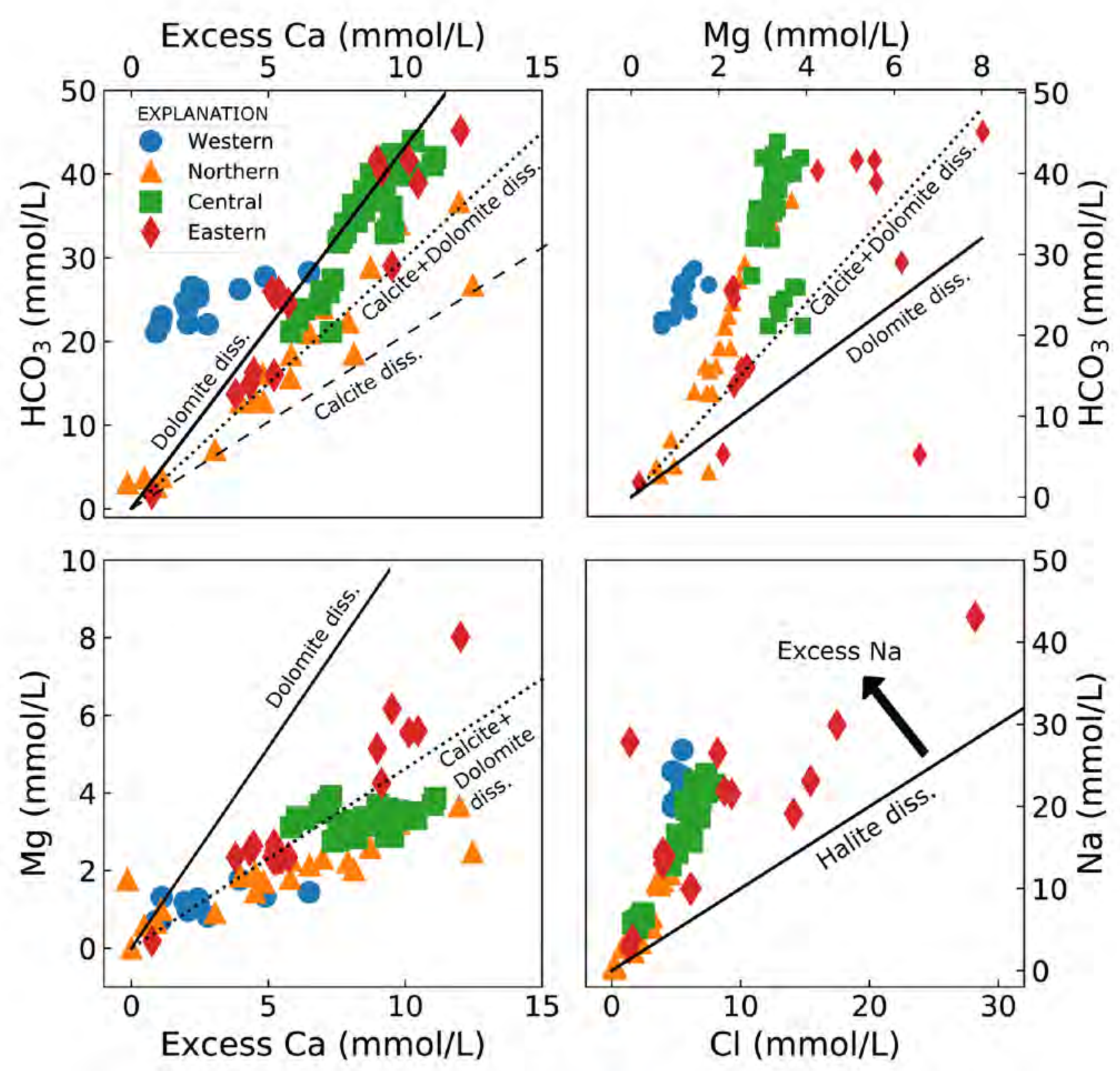

Figure 5. Geochemical attributes of the Manitou Springs aquifer, including excess calcium (Ca) versus bicarbonate $\left(\mathrm{HCO}_{3}\right)$, magnesium $(\mathrm{Mg})$ versus bicarbonate, excess calcium versus magnesium, and chloride $(\mathrm{Cl})$ versus sodium $(\mathrm{Na})$, in millimoles per liter (mmol/L) for geographically grouped flowing wells and springs. The lines display the trajectory dissolution (diss.) of calcite, dolomite, calcite and dolomite concurrently, and halite.

Finally, springwaters tend to have elevated silica concentrations, which is a common association in geothermal systems (Fournier, 1977). The use of silica geothermometry (Fournier, 1977) along with other analyses such as multireaction equilibrium geothermometry (King and others,
2016) can help to further define the geothermal system giving rise to the hot springs. Delineation and greater understanding of the heat source for the geothermal system can also enable predictive modeling to understand potential future behavior under differing climate and usage scenarios. 

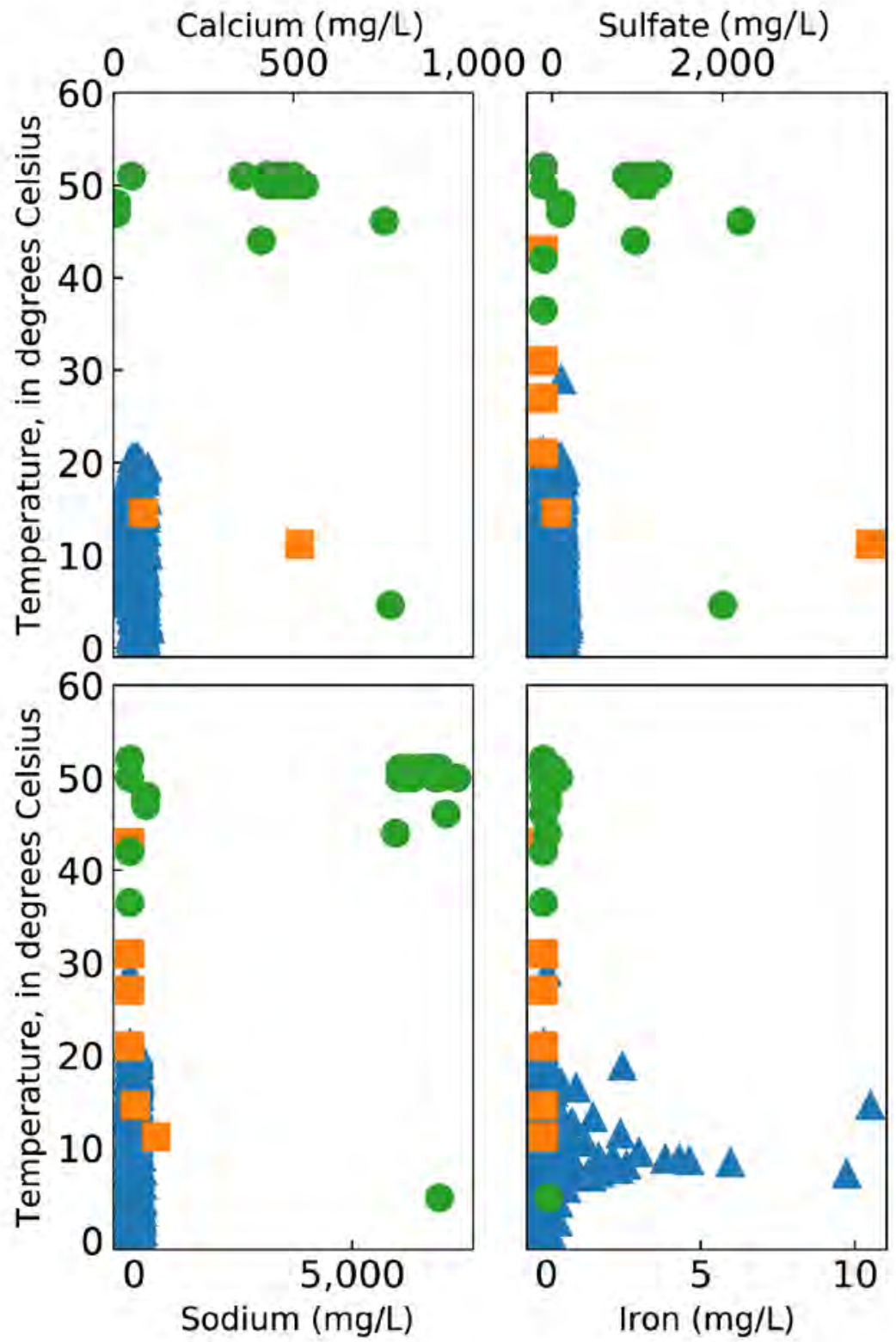

EXPLANATION

A Surface water

Well

Spring

\section{Chloride $(\mathrm{mg} / \mathrm{L})$}
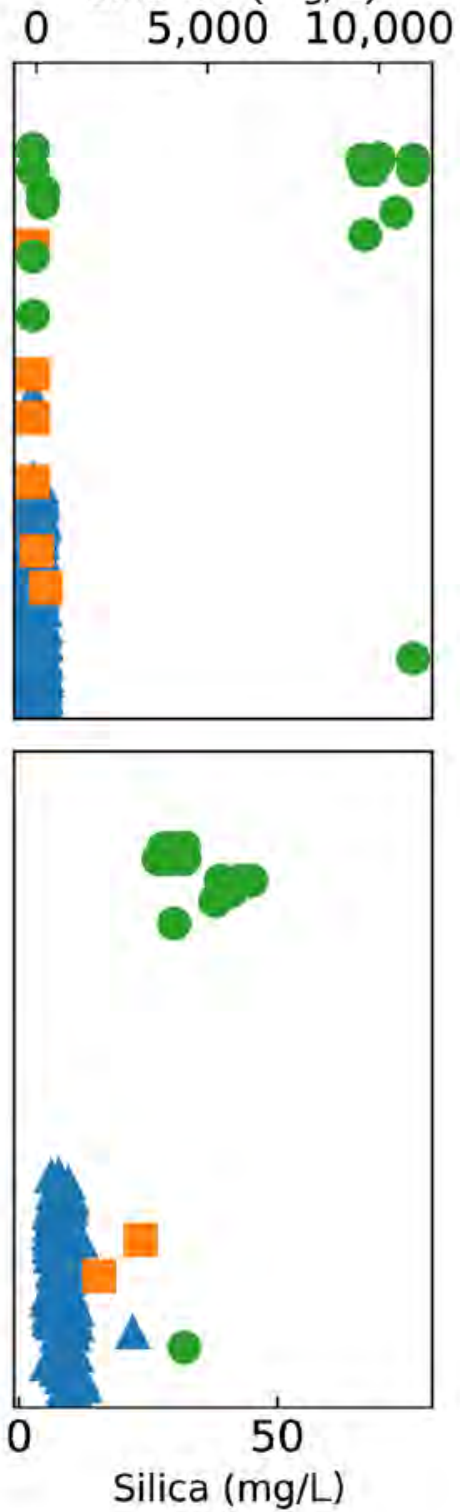

Figure 6. Water temperature versus concentrations of calcium, sulfate, chloride, sodium, iron, and silica in milligrams per liter (mg/L) for surface water (rivers and streams), wells, and springs in the vicinity of Glenwood Springs, Colorado. 


\section{Groundwater-Flow Model Development}

The Manitou Springs and Glenwood Springs aquifers occur in karstic rocks of Paleozoic age on the margins of the Colorado Rocky Mountains. Both aquifers are currently being studied to better understand flow dynamics, residence times, and sources of recharge. Numerical groundwater-flow modeling of these systems could be done to evaluate conceptual models more quantitatively with a goal of understanding potential future variability given changing recharge conditions and land use.

Hydrologic and geochemical data are available for the Manitou Springs aquifer. These data indicate that the primary recharge area for the aquifer is to the north and west of Manitou Springs and that groundwater becomes increasingly saturated with respect to calcite and dolomite as it flows downgradient to the east. These observations can assist in creating an initial numerical model, and geochemical data may provide a means by which to calibrate flow rates given the known rates of carbonate mineral dissolution and the distances between monitoring locations.

In contrast to the Manitou Springs aquifer, relatively few data are available for the Glenwood Springs aquifer. The available data indicate the presence of two hot spring systems with potentially different sources and (or) flow paths. Also, it appears there are no currently monitored wells that intersect the hot spring system, limiting interpretation as to residence times, flow paths, and other hydrologic details. Substantially more data are needed to develop a numerical groundwater-flow model of the Glenwood Springs aquifer.

\section{Acknowledgments}

This work was partially supported by the Manitou Mineral Springs Foundation and U.S. Geological Survey cooperative matching funds. The use of trade, firm, or product names in this paper is for descriptive purposes only and does not imply endorsement by the U.S. Government. Helpful comments were provided by Suzanne Paschke, Helen Malenda, and Jena Huntington.

\section{References Cited}

Appelo, C.A.J., and Postma, D., 2005, Geochemistry, groundwater, and pollution ( $2 \mathrm{~d}$ ed.): Amsterdam, the Netherlands, CRC Press, 649 p.

Bakker, M., and Schaars, F., 2019, Solving groundwater flow problems with time series analysis - You may not even need another model: Groundwater, v. 57, no. 6, p. 826-833, DOI: $10.1111 /$ gwat.12927.

Barbieri, M., Boschetti, T., Petitta, M., and Tallini, M., 2005, Stable isotope $\left({ }^{2} \mathrm{H},{ }^{18} \mathrm{O}\right.$, and $\left.{ }^{87} \mathrm{Sr} /{ }^{86} \mathrm{Sr}\right)$ and hydrochemistry monitoring for groundwater hydrodynamics analysis in a karst aquifer (Gran Sasso, Central Italy): Applied Geochemistry, v. 20, p. 2063-2081, DOI: 10.1016/j.apgeochem.2005.07.008.

Collenteur, R.A., Bakker, M., Caljé, R., Klop, S.A., and Schaars, F., 2019, Pastas-Open source software for the analysis of groundwater time series: Groundwater, v. 57, no. 6, p. 877-885, DOI: 10.1111/gwat.12925.

Cunningham, W.L., and Schalk, C.W., comps., 2011, Groundwater technical procedures of the U.S. Geological Survey: U.S. Geological Survey Techniques and Methods book 1, chap. A1, 151 p. [Also available at https://pubs.usgs.gov/tm/1a1/.]

Eisenhauer, R.J., 1983, Characterization of the Glenwood Springs and Dotsero Springs waters: Bureau of Reclamation Engineering and Research Center report REC-ERC-83-10, $52 \mathrm{p}$.

Eisenhauer, R.J., 1986, Characterization of Glenwood Springs and Dotsero Springs source aquifers: Bureau of Reclamation Engineering and Research Center report REC-ERC-86-1, $35 \mathrm{p}$.

Fournier, R.O., 1977, Chemical geothermometers and mixing models for geothermal systems: Geothermics, v. 5, p. $41-50$. 
Geldon, A.L., 1989, Hydrogeology of the Leadville Limestone and other Paleozoic rocks in northwestern Colorado, with results of aquifer tests at Glenwood Springs: U.S. Geological Survey Water-Resources Investigations Report 87-4195, 96 p.

Ghasemizadeh, R., Yu, X., Butscher, C., Padilla, I.Y., and Alshawabkeh, A., 2016, Improved regional groundwater flow modeling using drainage features - A case study of the central northern karst aquifer system of Puerto Rico (USA): Hydrogeology Journal, v. 24, p. 1463-1478, DOI: $10.1007 / \mathrm{s} 10040-016-1419-6$.

Goldscheider, N., Meiman, J., Pronk, M., and Smart, C., 2008, Tracer tests in karst hydrogeology and speleology: International Journal of Speleology, v. 37, no. 1, p. 27-40.

Huntington, J., Hegewisch, K., Daudert, B., Morton, C., Abatzoglou, J., McEvoy, D., and Erickson, T., 2017, Climate Engine-Cloud computing of climate and remote sensing data for advanced natural resource monitoring and process understanding: Bulletin of the American Meteorological Society, DOI: 10.1175/BAMS-D-15-00324.1.

Kalhor, K., Ghasemizadeh, R., Rajic, L., and Alshawabkeh, A., 2019, Assessment of groundwater quality and remediation in karst aquifers - A review: Groundwater for Sustainable Development, v. 8, p. 104-121, DOI: $10.1016 /$ j.gsd.2018.10.004.

Keller, J.W., Siddoway, C.S., Morgan, M.L., Route, E.E., Grizzell, M.T., Sacerdoti, R., and Stevenson, A., 2005, Geologic map of the Manitou Springs 7.5-minute quadrangle, El Paso and Teller Counties, Colorado: Colorado Geological Survey Open-File Report 03-19, 42 p., 1 map sheet.

King, J.M., Hurwitz, S., Lowenstern, J.B., Nordstrom, D.K., and McCleskey, R.B., 2016, Multireaction equilibrium geothermometry - A sensitivity analysis using data from the Lower Geyser Basin, Yellowstone National Park, USA: Journal of Volcanology and Geothermal Research, v. 328, p. 105-114, DOI: 10.1016/j.jvolgeores.2016.10.010.

Kirkham, R.M., Streufert, R.K., Budhan, J.R., Kunk, M.J., and Perry, W.J., 2001, Late Cenozoic regional collapse due to evaporite flow and dissolution in the Carbondale collapse center, west-central Colorado: The Mountain Geologist, v. 38, no. 4, p. 193-210.

Luiszer, F.G., 1997, Genesis of Cave of the Winds, Manitou Springs, Colorado: Boulder, University of Colorado, Ph.D. dissertation, 102 p., 10 tables, 18 figs., 6 pls.
Ma, R., Wang Y., Sun, Z., Zheng, C., Ma, T., and Prommer, H., 2011, Geochemical evolution of groundwater in carbonate aquifers in Taiyuan, northern China: Applied Geochemistry, v. 26, p. 884-897, DOI: 10.1016/j.apgeochem.2011.02.008.

Maslyn, R.M., DuChene, H.R., and Luiszer, F.G., 2017, Structural settings and hypogenic flow paths for three Colorado caves, in Klimchouk, A., Palmer, A.N., De Waele, J., Auler, A.S., and Audra, P., eds., Hypogene karst regions and caves of the world: Springer International Publishing, p. 575-590.

Mayo, A.L., and Muller, A.B., 1997, Low temperature diagenetic-metamorphic and magmatic contributions of external $\mathrm{CO}_{2}$ gas to a shallow ground water system: Journal of Hydrology, v. 194, p. 286-304.

Moral, F., Cruz-Sanjulián, J.J., and Olias, M., 2008, Geochemical evolution of groundwater in the carbonate aquifers of Sierra de Segura (Betic Cordillera, southern Spain): Journal of Hydrology, v. 360, p. 281-296, DOI: 10.1016/j.jhydrol.2008.07.012.

National Water Quality Monitoring Council, 2019, Water Quality Portal: National Water Quality Monitoring Council web page, accessed May 8, 2019, at https://www.waterqualitydata.us/.

Parkhurst, D.L., and Appelo, C.A.J., 2013, Description of input and examples for PHREEQC version 3-A computer program for speciation, batch-reaction, one-dimensional transport, and inverse geochemical calculations: U.S. Geological Survey Techniques and Methods, book 6, chap. A43, 497 p. [Also available at https://pubs.usgs.gov/tm/06/a43/.]

Plummer, L.N., Busby, J.F., Lee, R.W., and Hanshaw, B.B., 1990, Geochemical modeling of the Madison aquifer in parts of Montana, Wyoming, and South Dakota: Water Resources Research, v. 26, no. 9, p. 1981-2014, DOI: 10.1029/WR026i009p01981.

Shomaker and Associates, 2011, Studies relating to the mineral springs, Manitou Springs, Colorado: Albuquerque, New Mexico, John Shomaker and Associates, Inc., 223 p.

Toth, D.J., and Katz, B.G., 2006, Mixing of shallow and deep groundwater as indicated by the chemistry and age of karstic springs: Hydrogeology Journal, v. 14, p. 827-847.

Yuan, J., Xu, F., Deng, G., Tang, Y., and Li, P., 2017, Hydrogeochemistry of shallow groundwater in a karst aquifer system of Bijie City, Guizhou Province: Water, v. 9, no. 625,16 p., DOI: 10.3390/w9080625. 


\title{
Refining Methods to Estimate the Atmospheric Carbon Sink by Carbonate Dissolution
}

\author{
By Autumn Singer, ${ }^{1}$ Chris Groves, ${ }^{1}$ Jun Yan, ${ }^{2}$ Michael May, ${ }^{2}$ and Albert Meier ${ }^{3}$
}

\author{
${ }^{1}$ Western Kentucky University, Department of Earth, Environmental, and Atmospheric Sciences, Crawford Hydrology Laboratory, Bowling Green, KY 42101. \\ ${ }^{2}$ Western Kentucky University, Department of Earth, Environmental, and Atmospheric Sciences, Bowling Green, KY 42101. \\ ${ }^{3}$ Western Kentucky University, Department of Biology, Bowling Green, KY 42101. \\ (Email: autumn.forschler@wku.edu)
}

\section{Abstract}

Rising atmospheric carbon dioxide concentrations have motivated efforts to better quantify reservoirs and fluxes of Earth's carbon. Of these fluxes from the atmosphere, one that has received relatively little attention is the atmospheric carbon sink associated with carbonate mineral dissolution. Osterhoudt (2014) and Salley (2016) explored new normalization techniques to standardize a process for measuring carbon flux over large river basins. Singer (2017) extended these efforts to the 490,600-square kilometer Ohio River drainage basin and 11 major sub-basins. The study estimated dissolved inorganic carbon (DIC) flux leaving the sub-basins during water year 2014 based on secondary hydrogeochemical, geologic, and climatic data. A statistical correlation was established between DIC flux and time-volume normalization parameters among the sub-basins, which received alkalinity primarily through interactions with surface carbonates (coefficient of determination $\left[\mathrm{R}^{2}\right]$ of 0.97 , $\mathrm{p}$-value less than or equal to 0.001). Singer (2017) concluded that the normalization procedure appeared to be effective in estimating DIC flux among the seven sub-basins of the Ohio River which contained a minimum threshold of 8-percent surface carbonates (Allegheny, Monongahela, Licking, Kentucky, Green, Cumberland, and Tennessee), but was less effective among the four basins where surface carbonates represented less than the identified threshold (Wabash, Great Miami, Scioto, and Kanawha). Three of these four basins (Wabash, Great Miami, and Scioto) exhibit geology characteristic of formerly glaciated regions and were expected to receive alkalinity from sources other than surface carbonates.

The present work represents ongoing efforts to refine techniques for measuring carbon fluxes in large river basins. The Kanawha Basin was previously categorized among the group that did not receive alkalinity through interactions with surface carbonates. However, recent developments revealed considerable areas of exposed carbonates previously not evaluated by Singer (2017) in the Kanawha Basin. These new areas were identified upon expansion of the Kanawha
Basin to include the New and Gauley Basins, which drain through the Valley and Ridge physiographic province where substantial carbonate deposits are located at or near the surface. Once this exposed carbonate area is paired with climate data, the Kanawha Basin is likely to show a stronger agreement with the observed statistical relation between DIC flux and the time-volume normalization parameters shown by the Allegheny, Monongahela, Licking, Kentucky, Green, Cumberland, and Tennessee Basins. Such a result would support the hypothesis that the proposed time-volume normalization parameters are sufficient for producing reliable estimates of DIC flux from all sub-basins of the Ohio River that contain surface carbonates. This represents an important step towards validating a method to estimate atmospheric carbon flux among basins without reliance on direct hydrochemical measurements.

\section{References Cited}

Osterhoudt, L.L, 2014, Impacts of carbonate mineral weathering on hydrochemistry of the Upper Green River Basin, Kentucky: Western Kentucky University Masters Theses and Specialist Projects, Paper 1337, 81 p., accessed January 3, 2021, at http://digitalcommons.wku.edu/theses/1337.

Salley, D.C., 2016, Advancing methods to measure the atmospheric $\mathrm{CO} 2$ sink from carbonate rock weathering: Western Kentucky University Masters Theses and Specialist Projects, Paper 1603, 78 p., accessed January 3, 2021, at http://digitalcommons.wku.edu/theses/1603.

Singer, A.B., 2017, Measuring inorganic carbon fluxes from carbonate mineral weathering from large river basins - The Ohio River Basin: Western Kentucky University Masters Theses and Specialist Projects, Paper 2044, 152 p., accessed January 3, 2021, at https://digitalcommons.wku.edu/theses/2044. 


\title{
Abstracts-Tracers in Karst
}

\section{Using Groundwater Fauna as Biological Tracers to Determine Hydrogeological Parameters in Karst Aquifers}

\author{
By Kevin W. Blackwood, ${ }^{1,2}$ Laramie J. Edens, ${ }^{2}$ Michelle A.M. Allen, ${ }^{3}$ Jessica D. West ${ }^{3}$ and Cara Jackson ${ }^{3}$
}

${ }^{1}$ East Central University, Oka Institute, PMB J-4, Ada, OK 74820.

${ }^{2}$ Arbuckle Karst Geoscience LLC, 14090 CR 3588 Loop, Ada, OK 74820.

${ }^{3}$ East Central University, 1100 E. 14 $4^{\text {th }}$ Street, Ada, OK 74820.

(Email: karstgeoscience@gmail.com)

\begin{abstract}
This study tests the viability of using groundwater fauna as biological tracers to qualitatively assess the possibility of groundwater exchange between fault-anticlinal structures of the Arbuckle-Simpson aquifer in the Arbuckle Mountains of southern Oklahoma. Endemic groundwater fauna were collected and are being analyzed with regards to their phenotypic and genotypic signatures with the inference that if groundwater fauna are capable of migrating through permeability structures between fault-bounded anticlinal structures, then the pore apertures may be effective for exchanging "significant" volumes of groundwater between the same structures.
\end{abstract}

\section{Introduction}

Geology plays a significant role in the storage and transport of groundwater, as well as the distribution and diversification of subterranean and aquatic organisms. The effect that stratigraphic and structural features might have on hydrogeology is by acting as either conduits or barriers to groundwater flow (Mangin, 1994). Determining whether hydrologic connections exist between two terranes can be difficult, especially when time and hydraulic gradients might not be sufficient for the injection of chemical tracers or pumping tests might not be practical.

By using endemic groundwater fauna as biological tracers, hydrogeological parameters may be deduced by comparing genotypic and phenotypic relations between populations on either side of potential groundwater barriers due to allopatric speciation. If geologic barriers are effective in preventing the exchange of groundwater between strata or structures, they might also be effective in retaining populations of groundwater fauna and preventing the exchange of genetic material. On the contrary, if geologic barriers are not in place, or effective, the exchange of groundwater might also permit the migration of groundwater fauna between terranes and allow for the exchange of genetic material. The practical application of this technique could be used in determining potential environmental impacts caused by over-pumping or contaminant transport. In karst, these effects are most significant as the diameter of pores increases to more than 10 millimeters $(\mathrm{mm})$, the effective minimum aperture for the onset of turbulent flow and the beginning of true speleogenesis (Ford and Williams, 2007). Using groundwater fauna to confirm connections of this size would be appropriate because most juvenile groundwater fauna, measured during this study, are capable of navigating fracture apertures with diameters of about $1 \mathrm{~mm}$.

Looking at examples from the Arbuckle Mountains of southern Oklahoma, the genotypic and phenotypic relations of endemic groundwater fauna were examined using DNA barcoding and taxonomic methods. By employing these techniques, the effectiveness of various types of stratigraphic and structural features as either pathways or as barriers can be assessed in a region heavily altered by structural deformation and modified by karst processes. 


\section{Study Area}

The Arbuckle Mountains geologic province encompasses an area of approximately 2,500 square kilometers in southern Oklahoma (fig. 1). The region is characterized by intensely folded and faulted carbonates, sandstones, and shales of Late Cambrian through Middle Carboniferous age (Ham, 1973). The Early Ordovician carbonates of the Arbuckle and Simpson Groups compose the major portion of the hydrostratigraphic units known regionally as the Arbuckle-Simpson aquifer and are generally defined by outcrops on three main anticlinal structures: West Arbuckle Mountains (Arbuckle Anticline), Central Arbuckle Mountains (Tishomingo Anticline), and the East Arbuckle Mountains (Hunton Anticline) (Christenson and others, 2011). Groundwater flow within these structures appears to be complicated by lateral and vertical anisotropy (Halihan and others, 2009), and it is presently unknown if groundwater exchange is occurring between any of the structures.

\section{Methods}

Endemic groundwater fauna were used for this study because they represent a group of species taxonomically unique to this region. Species such as the Oklahoma Cave Amphipod (Allocrangonyx pellucidus) and Groundwater Isopod (Caecidotea acuticarpa) are found within the groundwater systems of all three anticlines (Graening and others, 2011). Their presence within the three anticlines could be indicative of paleo-groundwater connections that have since eroded away, or that groundwater connections currently exist and are permitting fauna migration between structures. Variations in phenotypes and genotypes are useful for indicating possible allopatric drift from physical isolating mechanisms.

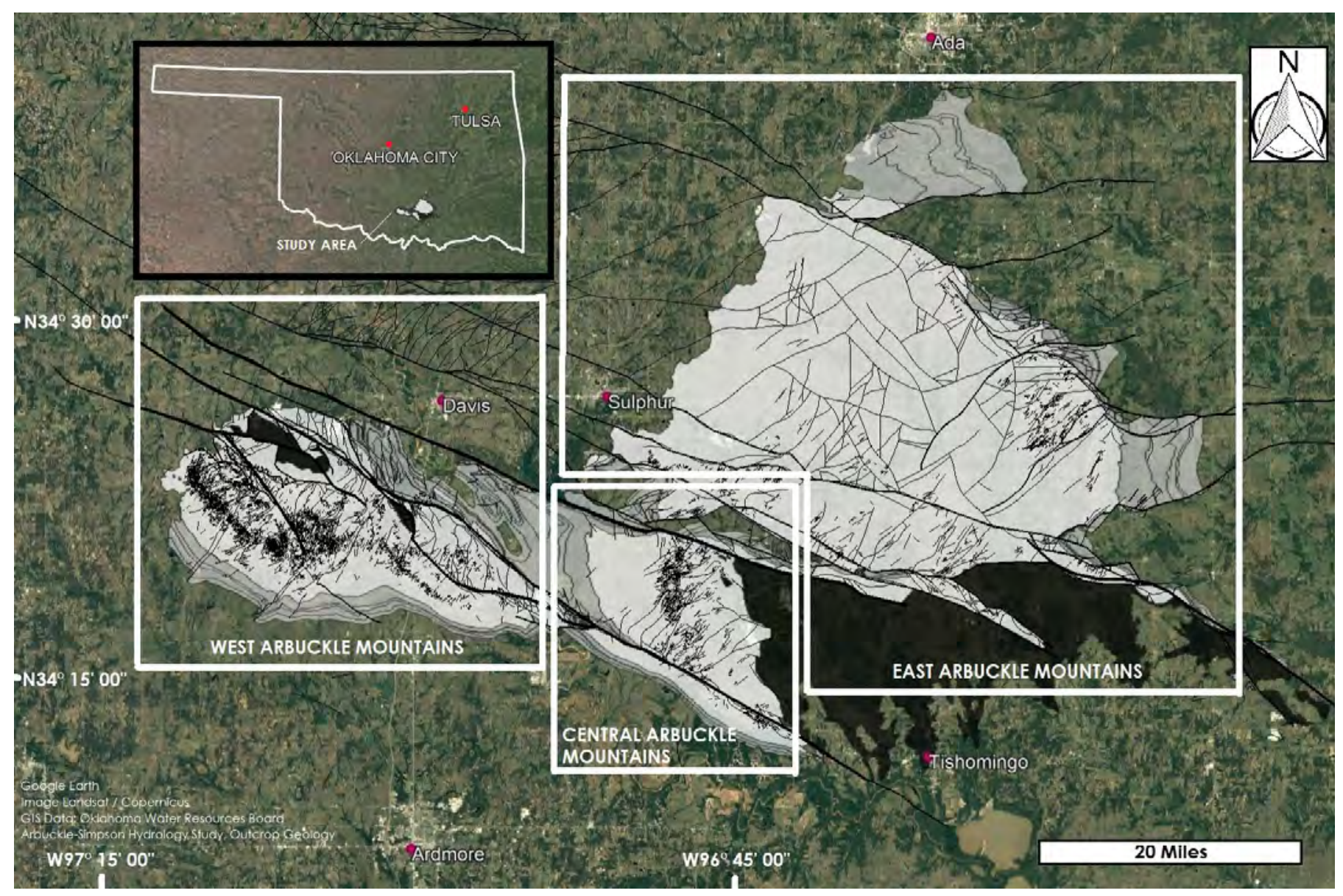

Figure 1. Regional map of the study area showing the three main anticlinal structures: West Arbuckle Mountains (Arbuckle Anticline), Central Arbuckle Mountains (Tishomingo Anticline), and East Arbuckle Mountains (Hunton Anticline). Faults and major fractures are shown as black lines. 
Groundwater fauna were collected from springs, caves, and wells on all three anticlinal structures using baited traps, dip nets, and aspirators. In total, 36 groundwater isopods and 22 amphipods from numerous sites across the three anticlines were collected. Specimens were stored alive in Nalgene containers, each from its own site and labeled accordingly. Specimens were then starved for approximately 48 hours to clear the digestive tract. Water was replaced regularly to prevent the consumption of excrement. This was a quality assurance protocol intended for the purpose of discarding foreign DNA. Specimens were photographed using a camera microscope at various magnifications and identified using dichotomous keys by Ward and Whipple (1959). Specimens were then pickled in 95 percent ethyl alcohol, each placed within individually labeled glass vials, and stored in freezers at -70 degrees Celsius. Tissues were later harvested from around the abdomen to avoid contamination from foreign DNA with the digestive tract. Tissues were ground and incubated over a 12-hour period, with ethanol precipitation used for DNA extraction, along with a series of buffers and solutions. Genus-specific primers were processed with samples using a polymerase chain reaction followed by a DNA gel extraction. The sequencing phase was not yet complete at the time this paper was submitted, and those results are not available.

\section{Results and Discussion}

Taxonomic investigations indicate several subtle differences in the size of the amphipod specimens as well as the structure of the head. However, the structure of the telson is noticeably different between specimens collected on the Arbuckle Anticline and those collected on the Tishomingo and Hunton Anticlines. The amphipods of the Arbuckle Anticline contain a curved telson (fig. 2) whereas those on the Tishomingo and Hunton Anticlines feature a straight telson (fig. 3).

Allocrangonyx pellucidus specimens collected by Mackin (1935) were initially described as belonging to the genus Niphargus but were redescribed by Schellenberg (1936) as belonging to the genus Allocrangonyx. A review of the descriptions by both taxonomists showed that neither made mention of a curved telson. Mackin (1935) had collected his specimens from the Hunton Anticline and his descriptions are consistent with the morphology of those collected during our investigation. It could be inferred that the curved telson represents a distinct population on the Arbuckle Anticline and that a potential isolating mechanism could also be acting as a barrier to groundwater flow. However, the specimens collected from the Arbuckle Anticline are typically larger than those collected on the other two anticlinal structures. It also could be that the curved telson is something that is expressed with maturity, but additional specimens will need to be collected and examined for statistical analysis to determine if this might be the case.

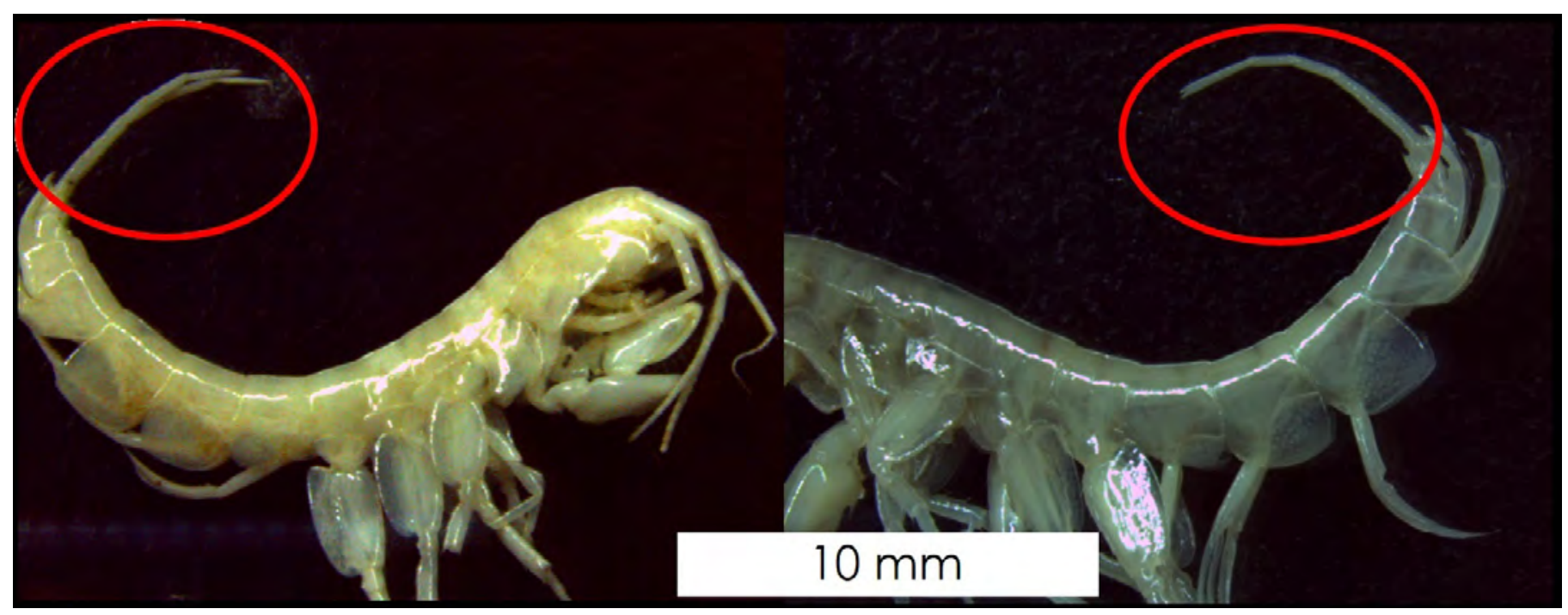

Figure 2. Amphipods from the Arbuckle Anticline featuring a curved telson. 


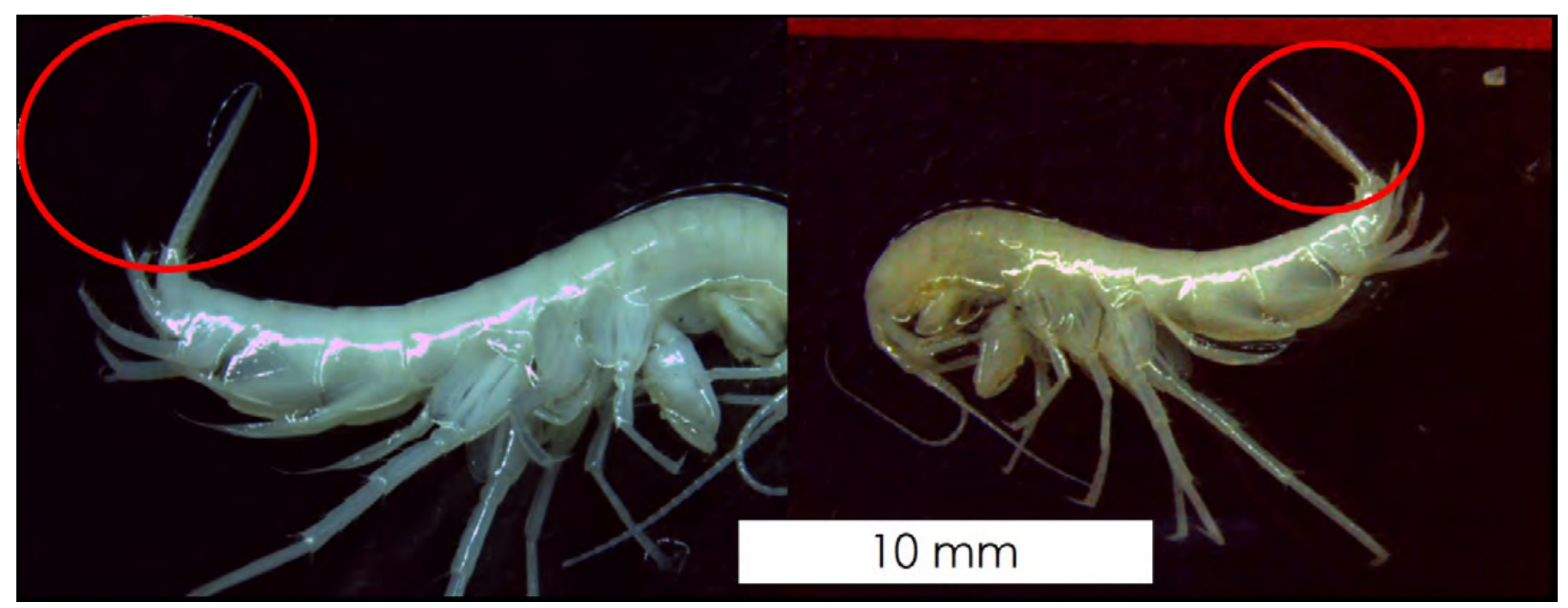

Figure 3. Amphipods from the Hunton and Tishomingo Anticlines featuring straight telsons.

Caecidotea acuticarpa was also used in this study, but no differentiating characteristics could be identified between specimens. Furthermore, during the starvation process, two of the isopods had exited the water and were observed climbing the walls of the beaker containing them (fig. 4). It was determined that because the isopods could emigrate from the phreatic environment, they may not be ideal for use as biological tracers in determining the connectedness of groundwater hydrostratigraphic units. The amphipods lack the appendages necessary for effective mobility outside of the phreatic environment. Because of this and their relative abundance, they appear to be the most viable specimens for determining the connectedness of groundwater units. This investigation relies heavily on results gleaned from the genetics data, which will help to "shed some light" on the cryptic variations to determine how closely or distantly related these populations are to one another.

\section{Acknowledgments}

The authors would like to extend their appreciation to the following individuals and entities for their assistance and support throughout this study: Britney Temple, Brad Woods, Eric Fiorentino, Lainee Sanders, Thomas Thompson, Camille Schlegel, Kelli Hansen, Karsyn Johnson, Dean Stewart, Bruce Mooring, The Oka Institute, East Central University, the Arbuckle Mountains Grotto of the National Speleological Society, and especially to all the landowners for access to groundwater sites.

Note: All specimens collected during this study were permitted under Oklahoma Department of Wildlife Conservation Scientific Collector's Permit \#7180. 


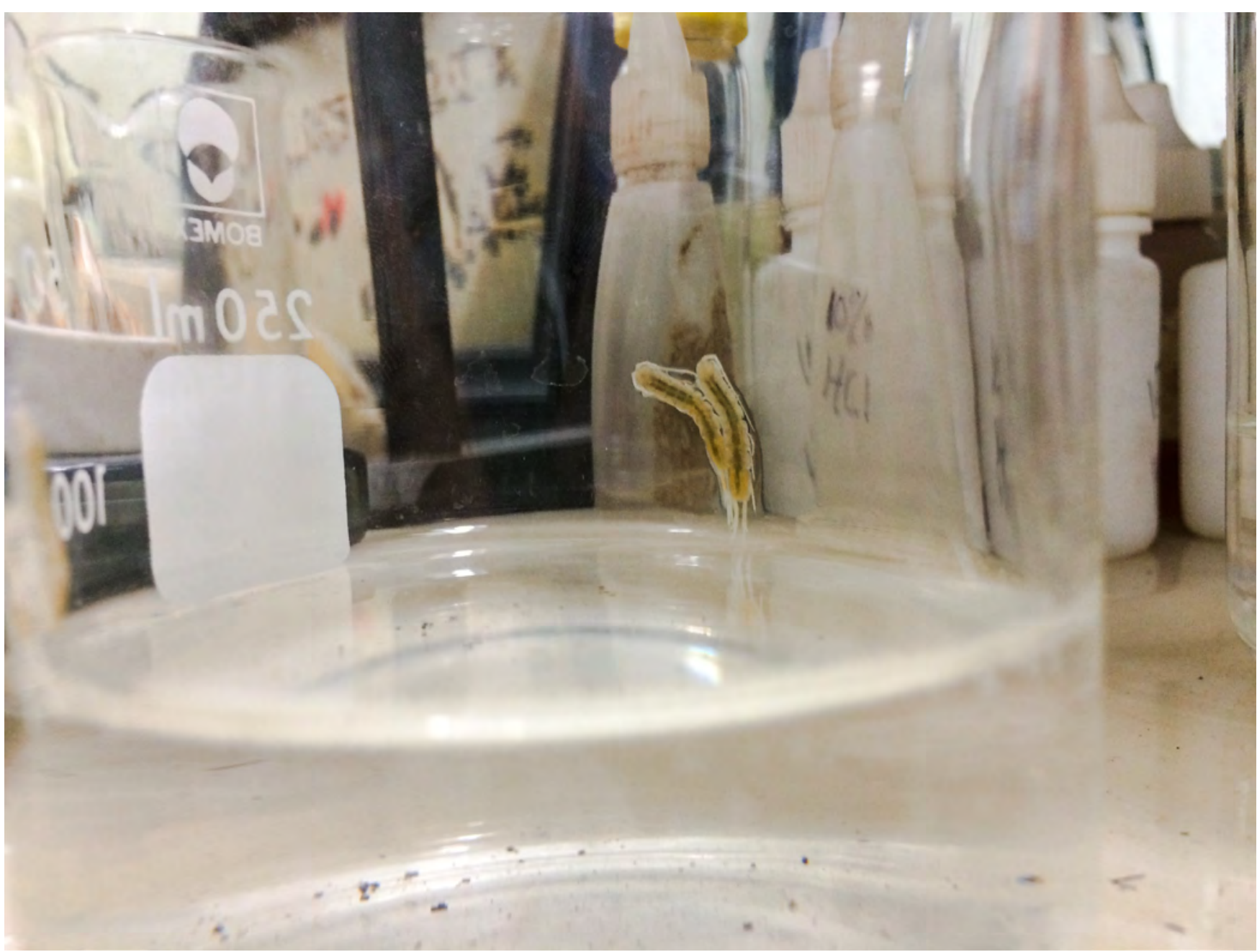

Figure 4. Isopod climbing up the walls of a glass beaker during the starvation phase.

\section{References Cited}

Christenson, S.C., Osborn, N.I., Neel, C.R., Faith, J.R., Blome, C.D., Puckett, J., and Pantea, M.P., 2011, Hydrogeology and simulation of groundwater flow in the Arbuckle-Simpson aquifer, south-central Oklahoma: U.S. Geological Survey Scientific Investigations Report 2011-5029, 104 p.

Ford, D., and Williams, P., 2007, Karst hydrogeology and geomorphology: West Sussex, England, John Wiley and Sons, Ltd., p. 112-117.

Graening, G.O., Fenalio, D.B., and Slay, M.E., 2011, Cave life of Oklahoma and Arkansas-Exploration and conservation of subterranean biodiversity: Norman, University of Oklahoma Press, p. 158-159.

Halihan, T., Mouri, S., and Puckett, J., 2009, Evaluation of fracture properties of the Arbuckle-Simpson aquifer: Final report for the Arbuckle-Simpson hydrology study, Oklahoma State University, 64 p.
Ham, W.E., 1973, Regional geology of the Arbuckle Mountains, Oklahoma: Oklahoma Geological Survey Special Publication 73-3, 61 p.

Mackin, J.G., 1935, Studies on the crustacea of Oklahoma, III. Subterranean amphipods of the genera Niphargus and Boruta: Transactions of the American Microscopical Society, v. 54, no. 1, p. 41-51.

Mangin, A., 1994, Karst hydrogeology, in Gibert, J., Danielopol, D.L., and Stanford, J.A., eds., Groundwater ecology: San Diego, Academic Press, p. 44-63.

Schellenberg, A., 1936, Die amphipodengattungen um crangonyx, ihre verbreitung und ihre arten, Mitteilung Zoological Museum, Berlin, v. 22, p. 31-43.

Ward, H.B., and Whipple, G.C., 1959, Fresh-water biology (2d ed.): New York, John Wiley and Sons, Inc., p. 869-877. 


\title{
Recharge Area Delineation for Manitou Cave, DeKalb County, Alabama
}

\author{
By Benjamin V. Miller ${ }^{1}$ \\ 'U.S. Geological Survey, 640 Grassmere Park, Suite 100, Nashville, TN 37211. \\ (Email: bvmiller@usgs.gov)
}

\begin{abstract}
When an agency is tasked with determining whether to add a species to the Endangered Species List, one of the components examined is potential threats to the biota. In 2010, the U.S. Fish and Wildlife Service (USFWS) was petitioned to federally list the Manitou Cave Snail (Antrorbis breweri), a stygobiont endemic to Manitou Cave in northwestern Alabama. Knowing the recharge area for a cave or spring is critical to identifying potential threats because of the interconnectivity between surface activities and groundwater quality/quantity in karst areas. With regard to Manitou Cave, potential threats may include recent subdivision developments, a nearby active quarry, land clearing, and several major
\end{abstract}

highways. The 1.7-kilometer-long cave is currently owned and managed by a non-profit organization, Manitou Cave of Alabama, who oversees management, restoration, research, and documentation. In 2016, talks began between state and federal agencies and the new management in an effort to initiate new research and to determine whether the snail merited listing. In 2019, a cooperative project between the USFWS and the U.S. Geological Survey was started to delineate the recharge area for Manitou Cave using dye tracing. The current research will be used by the USFWS to determine primary threats and to aid in possible listing of the Manitou Cave Snail as an endangered species. 


\title{
Abstracts-Karst Hazards
}

\section{Methodology for a Preliminary Karst Depression Density Map of the Conterminous United States}

\author{
By Daniel H. Doctor, ${ }^{1}$ Jeanne Jones, ${ }^{2}$ Nathan Wood ${ }^{3}$ Jeff Falgout, ${ }^{4}$ and Natalya I. Rapstine ${ }^{4}$
}

\author{
'U.S. Geological Survey, 12201 Sunrise Valley Drive, Reston, VA 20191. \\ ${ }^{2}$ U.S. Geological Survey, 350 N. Akron Rd., Moffett Field, CA 94035. \\ ${ }^{3}$ U.S. Geological Survey, 2130 SW 5th Avenue, Portland, OR 97201. \\ ${ }^{4}$ U.S. Geological Survey, Denver Federal Center, Mail Stop 302, Denver, CO 80225. \\ (Email: dhdoctor@usgs.gov)
}

\section{Abstract}

Modern methods for the assessment of sinkhole hazard susceptibility are predicated upon knowledge of pre-existing closed depressions in karst areas. In the United States, inventories of existing karst depressions are often obtained through inconsistent methodologies applied at the state or county level and at various scales. Here, a first attempt at defining a karst closed depression inventory across the conterminous United States is presented using a common methodology. A modified version of the level-set algorithm by Wu and others (2019) was used for extraction of closed depressions from the $1 / 3$ arc-second (approximately 10 meters horizontal resolution and 1.55 meters vertical resolution) U.S. Geological Survey (USGS) National Elevation Dataset (NED) (USGS, 2020a). The full NED was first conditioned using the methods outlined by Wall and others (2015) to reduce the creation of artificial closed depressions. These methods breach digital dams at road and stream crossings by using the flowlines and transportation route vectors from the USGS National Map (USGS, 2020a). All computations were run on the USGS "Yeti" high-performance computing cluster (USGS, 2020b). Processing ran for over 12,000 hours on more than 6,600 cores. Total data storage for the processing on 927 digital elevation models was about 5.1 terabytes.

The resulting depression polygons extracted from the entire NED were selected to be retained if located within a 1-kilometer buffer zone of geologic units having the potential for karst as defined by Weary and Doctor (2014), and all others were discarded. Depressions less than $600 \mathrm{~m}^{2}$ in area and less than $2 \mathrm{~m}$ in maximum depth were also discarded. The remaining depressions were then further reduced by those intersecting a 50-meter buffer zone around road and stream vectors from the National Map to avoid including artificial depressions from manmade runoff control structures. Subsequently, depressions were further selected for removal when they intersected areas within the categories of High Intensity, Medium Intensity, and Low Intensity Developed Land, Woody Wetlands, Emergent Herbaceous Wetlands, and Open Water as defined in the National Land Cover Database (NLCD) (USGS, 2016). Finally, depressions were removed when located in areas of frequently flooded soils (alluvium) based on data from the Gridded Soil Survey Geographic Database (gSSURGO) (U.S. Department of Agriculture, 2020 ) or in areas with greater than about $15 \mathrm{~m}$ of glacial sediment cover based on data from Soller and others (2012). The remaining depression polygons totaled nearly 165,000 , and the centroid points of these polygons were then used as the input to create a nationwide karst depression density map on a 1-kilometer grid. The resulting density map (fig. 1) was compared with karst depression density maps for diverse karst regions in six states with existing closed depression inventories: Alabama, Kentucky, Minnesota, Missouri, Tennessee, and Virginia. The results obtained from these methods, which were applied universally across the nation, compared favorably with the individual state closed depression density maps and illustrated regional sinkhole hotspots in known areas of well-developed karst. Limitations of the automated methods include false positive depressions resulting from artifacts generated during the computer processing of the digital elevation models, and inclusion of depressions resulting from non-karst geomorphic processes. More thorough examination of the screening criteria for depressions is required to refine the results. 
$130^{\circ} 0^{\circ} \mathrm{I}^{\circ} \mathrm{W}$ $120^{\circ} \mathrm{pow}^{\circ}$ ${ }^{110^{\circ} 0^{\circ} \mathrm{I}^{\circ} \mathrm{W}}$ $100^{\circ} \mathrm{I}^{\circ \mathrm{WW}}$ 90.0' ${ }^{80^{\circ} 0^{\circ} 0^{\circ} \mathrm{W}}$ $70^{\circ} 0^{\circ} 0^{\circ \mathrm{WW}}$

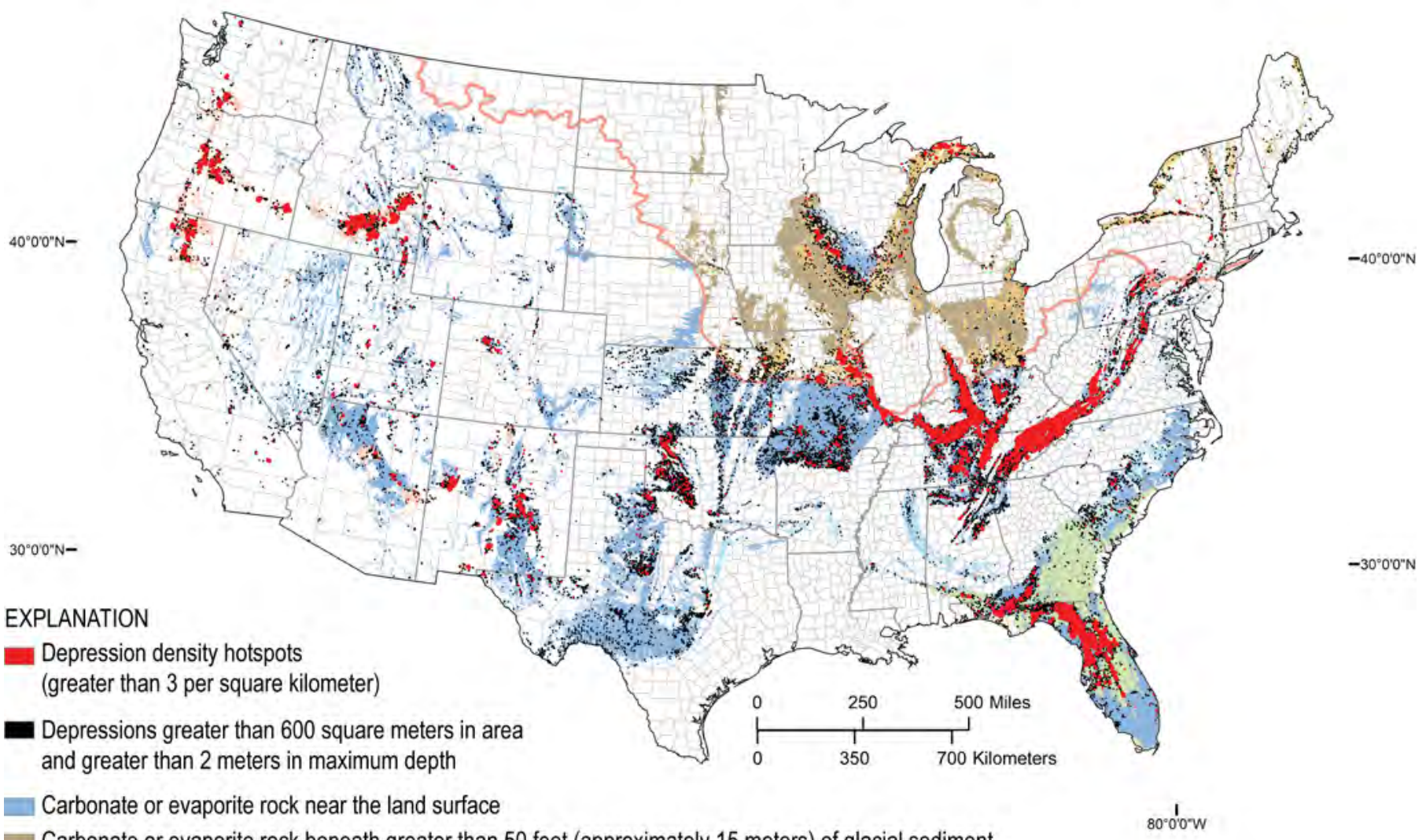

Carbonate or evaporite rock beneath greater than 50 feet (approximately 15 meters) of glacial sediment

Carbonate or evaporite rock beneath less than 50 feet (approximately 15 meters) of glacial sediment

Carbonate or evaporite rock beneath less than 300 feet (approximately 91 meters) of insoluble sediment

Unconsolidated carbonate or calcareous rock near the land surface

Volcanic pseudokarst in basalt or other igneous rock

- Maximum extent of Pleistocene glaciation

(geologic map unit data from Weary and Doctor, 2014)

Figure 1. Preliminary closed depression "hotspots" in areas having bedrock potential for karst within the conterminous United States (U.S.). Large numbers of depressions in eastern Kansas, along the southern Atlantic Coastal Plain, in glaciated regions of the midwest and northeastern U.S., and in volcanic pseudokarst regions of the western U.S., indicate that additional work needs to be done to determine where in these regions the depressions result from karst processes or from other geomorphic processes. 


\section{References Cited}

Soller, D.R., Packard, P.H., and Garrity, C.P., 2012, Database for USGS Map I-1970, Map showing the thickness and character of Quaternary sediments in the glaciated United States east of the Rocky Mountains: U.S. Geological Survey Data Series 656, accessed January 23, 2020, at http://pubs.usgs.gov/ds/656/.

U.S. Department of Agriculture, Soil Survey Staff, 2020, Gridded Soil Survey Geographic (gSSURGO) database for the conterminous United States: United States Department of Agriculture, Natural Resources Conservation Service web page, accessed January 23, 2020, at https://data.nal.usda.gov/dataset/gridded-soil-surveygeographic-database-gssurgo/.

U.S. Geological Survey [USGS], 2016, NLCD 2016 Land Cover (CONUS): U.S. Geological Survey National Land Cover Database for the continental United States, accessed January 23, 2020, at https://www.mrlc.gov/data/nlcd-2016-land-cover-conus.

U.S. Geological Survey [USGS], 2020a, The National Map: U.S. Geological Survey National Map web page, accessed January 23, 2020, at https://viewer.nationalmap.gov/basic/.
U.S. Geological Survey [USGS], 2020b, USGS Yeti supercomputer: U.S. Geological Survey Science Analytics and Synthesis program, Advanced Research Computing (ARC) group web page, accessed January 23, 2020, at https://www.usgs.gov/core-science-systems/sas/arc.

Wall J., Doctor, D.H., and Terziotti, S., 2015, A semi-automated tool for reducing the creation of false closed depressions from a filled LIDAR-derived digital elevation model, in Doctor, D.H., Land L., and Stephenson J.B., eds, Proceedings of the 14th Multidisciplinary Conference on Sinkholes and the Engineering and Environmental Impacts of Karst, Oct. 5-9, Rochester, Minnesota: National Cave and Karst Research Institute Symposium 5, p. 255-262.

Weary, D.J., and Doctor, D.H., 2014, Karst in the United States-A digital map compilation and database: U.S. Geological Survey Open-File Report 2014-1156, 23 p.

Wu, Q., Lane, C.R., Wang, L., Vanderhoof, M.K., Christensen, J.R., and Liu, H., 2019, Efficient delineation of nested depression hierarchy in digital elevation models for hydrological analysis using level-set method: Journal of the American Water Resources Association, v. 55, issue 2, p. 354-368. 


\title{
Salt Dissolution Tectonism and Spatiotemporal Aspects of Juxtaposed Sinkholes and Pseudo-Sinkholes of the Foreland Alberta Basin, Canada
}

\author{
By Paul L. Broughton ${ }^{1}$ \\ ${ }^{1}$ Broughton and Associates, P.O. Box 6976, Calgary, Alberta, Canada T2P 2G2. \\ (Email: broughton@shawcable.com)
}

\begin{abstract}
Dissolution trends in the Middle Devonian Prairie Evaporite configured the karstic Devonian limestone floor and overlying Lower Cretaceous Athabasca Oil Sands deposit in the northeast part of the foreland Alberta Basin. Multi-staged removal of up to 130 meters of salt occurred during the Late Jurassic and into the Early Cretaceous, concurrent with Aptian deposition of the McMurray Formation. The pre-Cretaceous paleotopography was configured as a karstic limestone terrain, which was further reconfigured upon burial as the sub-Cretaceous unconformity structural surface. Subsidence and collapse of the strata in response to underlying salt removal resulted in differential subsidence of kilometer-scale fault blocks, multi-kilometer-long sinkhole valleys, smaller-scale breccia pipes, and tens of meters-deep sinkholes. The southwestern area of the Bitumount Trough was the site of a cataclysmic collapse event that occurred upon removal of a 100-meter-thick interval of salt beds, resulting in a collision between kilometer-scale blocks, intensely shattering the limestone beds. This fragmentation uniquely permitted development of deeply weathered rock profiles that transitioned into ghost-rock karstification with pseudo-sinkholes. This style of ghost-rock karstification occurred as an isolated area of the southwestern Bitumount Trough, which developed within a regional terrain of salt dissolution subsidence and collapse tectonism. The area was subsequently covered by McMurray Formation fluvial-estuarine sand deposits, the principal reservoir rock of the Athabasca Oil Sands.
\end{abstract}

\section{Introduction}

The Athabasca Oil Sands, the largest of the three Lower Cretaceous bitumen-saturated sand deposits in northeast Alberta (fig. 1), accumulated on a karstic limestone paleotopographic surface of Middle-Upper Devonian Waterways Formation strata (Hein and Cotterill, 2006; Hein and others, 2013; Broughton, 2013, 2015, 2017a, 2018a). This part of the foreland Alberta Basin is characterized by a unique juxtaposition of salt dissolution-collapse sinkholes and pseudo-sinkholes resulting from ghost-rock karstification. They were directly or indirectly responsive to removal of an 80- to 130-meter-thick interval of halite-dominated beds of the Prairie Evaporite, 200-300 meters (m) deeper (Broughton, 2013, 2015) (figs. 2 and 3). The impact of multi-staged salt dissolution tectonism varied from the formation of 10 - to 90-meter-deep sinkholes to tens of kilometers-long chains of differentially subsided fault blocks, all of which configured the Devonian karstic limestone paleotopography and distribution of overlying Lower Cretaceous McMurray Formation strata. The largest salt dissolution collapse structure was the 100-kilometer-long Bitumount Trough (fig. 3), which was infilled by deposits of the McMurray Formation, forming the host reservoir rock of the Athabasca Oil Sands (Broughton, 2013, 2015, 2016; Barton and others, 2017).

This study documents the interplay between (1) multi-staged salt dissolution trends within the Prairie Evaporite, resulting in subsidence and collapse of the overlying strata and formation of breccia pipe-sinkhole complexes, and (2) weathered rock profiles on the Devonian paleotopographic surface, indirectly linked to the salt dissolution tectonism-induced fault block collapses and fragmentation that localized a unique type of pseudo-sinkhole-dominated karst terrain. 


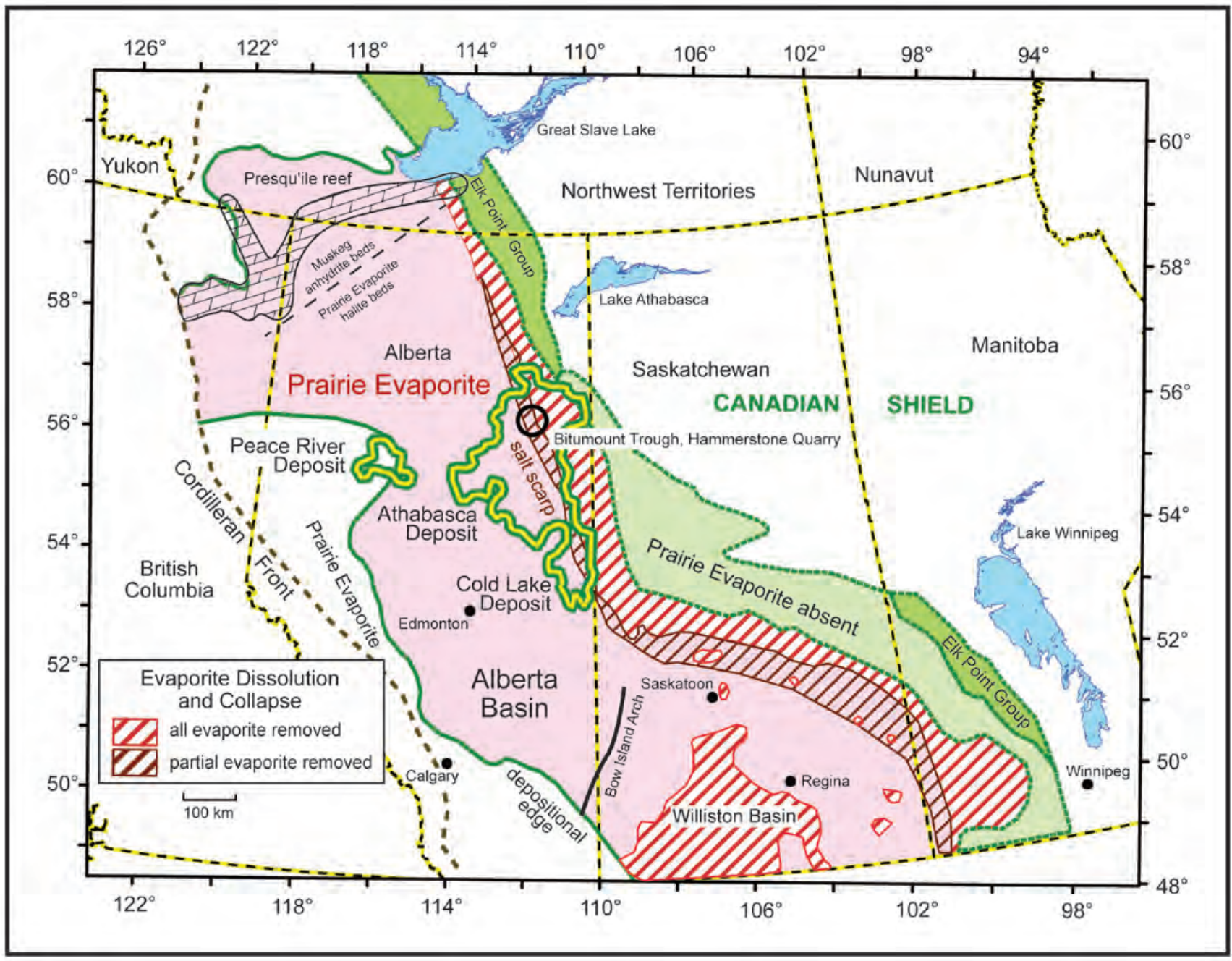

Figure 1. Regional salt dissolution trends developed within the Middle Devonian Prairie Evaporite (pink) across the Western Canada Sedimentary Basin. The Athabasca Oil Sands deposit overlies a 300-kilometer-long segment of the 1,000-kilometer-long dissolution trend developed along the eastern margin of the halite-dominated Middle Devonian salt basin. Modified from Broughton $(2013,2015)$. 


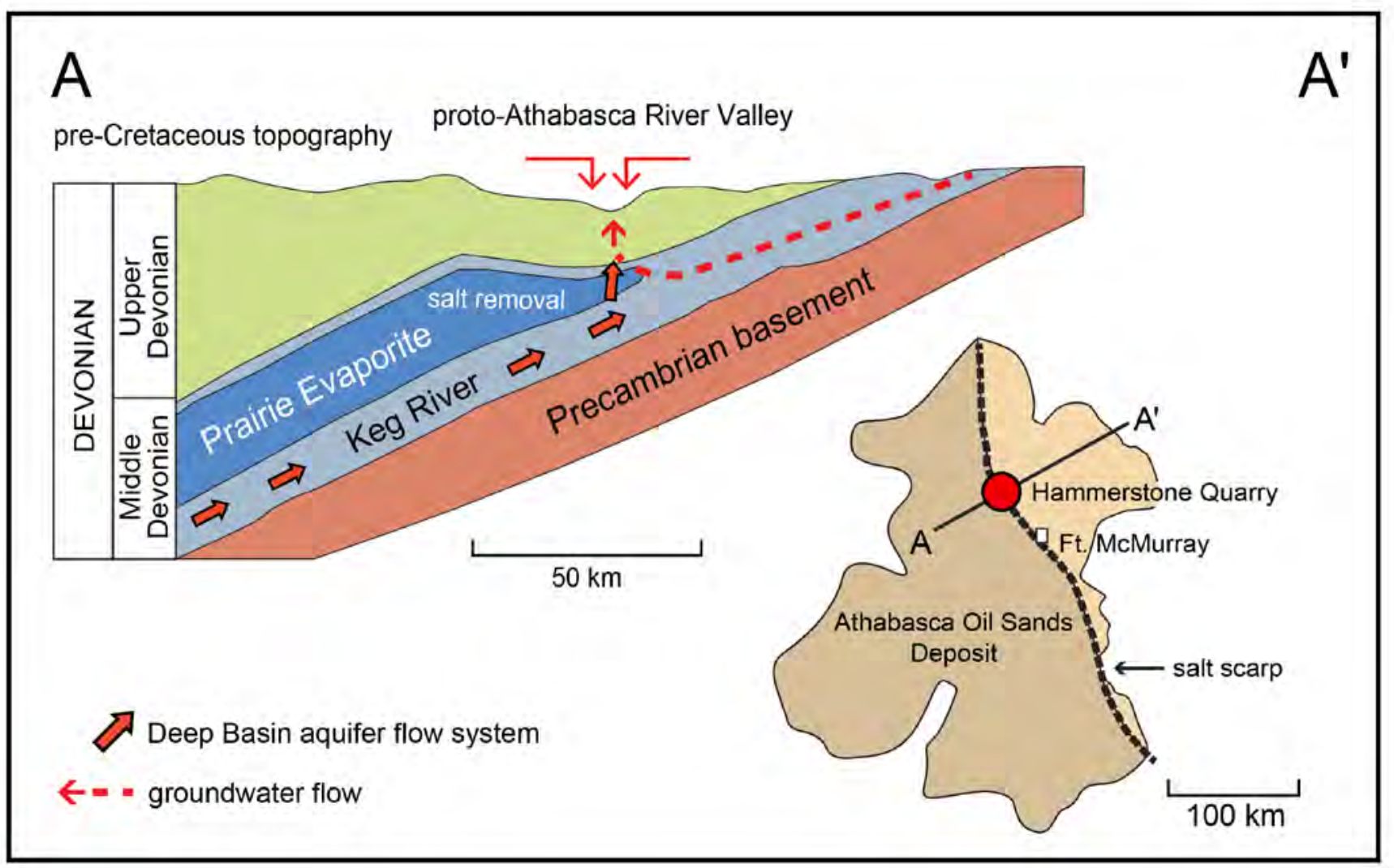

Figure 2. Schematic cross section of pre-Cretaceous paleotopography prior to deposition of the McMurray Formation (Aptian). The Hammerstone Quarry is located along the southwest margin of the Bitumount Trough.

\section{Regional Geology}

The Lower Cretaceous Athabasca Oil Sands deposit is located in the northeast Alberta Basin, part of the Western Canada Sedimentary Basin (fig. 1). The McMurray Formation, the principal host rock of the Athabasca Oil Sands deposit, accumulated unconformably on a Middle-Upper Devonian karstic limestone paleotopographic surface.

The Athabasca deposit accumulated above a 300-kilometer-long segment of a 1,000-kilometer- long regional dissolution trend in the Middle Devonian Prairie Evaporite, extending along the eastern up-dip margins of the Alberta and Williston Basins of the overarching Western Canada Sedimentary Basin (fig. 1) (Holter, 1969; Meijer Drees, 1994; Hein and others, 2013; Broughton, 2013, 2015;
Walker and others, 2017). Salt dissolution events impacting the Prairie Evaporite of the Alberta Basin were responsive to Middle-Late Jurassic to Early Cretaceous Cordilleran tectonism (Grobe, 2000). Surface erosion removed up to 1.5 kilometers of post-Devonian Paleozoic strata (Deroo and others, 1977; Hein and others, 2013; Broughton, 2013, $2015,2018 \mathrm{a}, \mathrm{b})$. This resulted in preservation of only $400 \mathrm{~m}$ of Paleozoic strata below the Athabasca Oil Sands, mostly represented by Devonian formations. Segments of these regional dissolution trends in both the Alberta and Williston Basins were reactivated during the Pleistocene as subglacial meltwaters flowed from near the subcrop zero edge into the shallow subsurface and came in contact with the Prairie Evaporite salt beds (Grasby and Chen, 2005; Broughton 2017a, c; Hauck and others, 2017). 


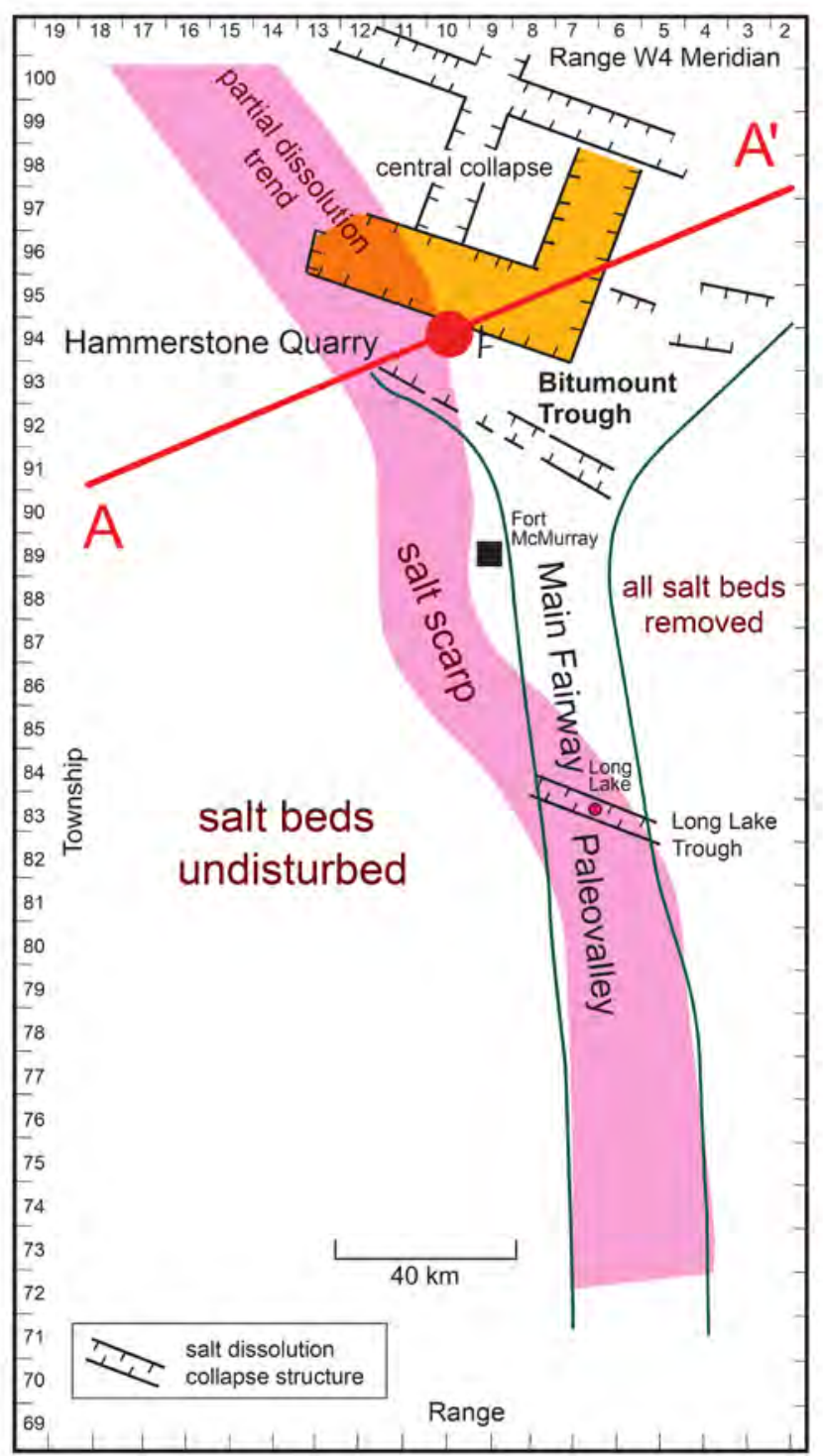

Figure 3. Devonian limestone karstic paleotopography showing Main Fairway Paleovalley and Bitumount Trough after surface erosion during the Cordilleran orogeny removed as much as 1.5 kilometers of Devonian and post-Devonian (pre-Aptian) strata along the foreland Alberta Basin. The 10- to 20-kilometer-wide salt scarp represents the position of the westward migrating partial dissolution front, separating areas of complete salt removal to the east from undisturbed salt beds to the west. Additional collapse structures such as at Long Lake follow the trace of the salt scarp. The illustrated map area includes the Alberta Land Survey, a checkerboard of Townships (northerly) and Ranges (westerly), west of the $4^{\text {th }}$ Meridian. Each Township is 36 square miles.

\section{Salt Dissolution Subsidence and Collapse Structures}

Pre-Cretaceous stages of Prairie Evaporite salt bed dissolution configured the overlying Devonian karstic paleotopography. The salt dissolution tectonism continued into the Aptian and further impacted the configuration of the buried karstic limestone surface as the sub-Cretaceous unconformity structure (fig. 3). Subsurface removal of 80-130 m of halite-dominated beds and secondary anhydrite intervals occurred as the dissolution front migrated west-northwest only $200 \mathrm{~m}$ below the karstic limestone surface. This migration of the salt dissolution front continued during Aptian deposition of the overlying McMurray Formation. The northwest-trending dissolution front resulted in a 10- to 20-kilometer-wide salt scarp consisting of partial salt bed removal. This scarp separated areas of complete salt removal to the east from undisturbed beds to the west. These subsurface salt dissolution processes resulted in saline seeps at the surface during the Early Cretaceous (Broughton, 2018a, b) and the Quaternary (Gibson and others, 2013; Cowie and others, 2014a, b, 2015; Gue and others, 2015). The saline water seeps continue to the present day (Jasechko and others, 2012; Gue and others, 2015, 2017; Birks and others, 2018).

During the Middle Jurassic-Early Cretaceous (pre-Aptian) hiatus, meteoric water moving into the shallow subsurface was channeled along permeability-enhanced trends in the Keg River strata and overlying interbedded dolomite units of the lower Prairie Evaporite. Salt removal along the margins of Keg River reefs resulted in prominent dissolution trends oriented northwest and northeast, paralleling lineaments propagated upward into Phanerozoic strata that resulted from craton block displacements. These fracture trends likely included a strike-slip component and are difficult to fully ascertain by geophysical measurements (Broughton, 2013, 2016). This parallelism was reinforced by removal of overlying thick salt build-ups along the margins of the reef trends compared to deposition of a thinned salt section above the reefs. These Cordilleran salt removal trends resulted in water movement up-section and up-structure to the northeast toward the basin margin, responsive to craton deformation, basin loading, or both (Bachu and Underschultz, 1993; Bachu and others, 1993; Bachu, 1999; Broughton, 2013, 2017a, b). In contrast, Quaternary subglacial meltwaters moving into the shallow subsurface resulted in top-down removal of the salt section (Hauck and others, 2017). 


\section{Bitumount Trough and the Salt Scarp}

Salt beds up to $130 \mathrm{~m}$ thick were removed prior to and during deposition of the McMurray Formation, culminating in the formation of the 100-kilometer-long, V-shaped, Bitumount Trough (fig. 3). A significant stage of salt removal occurred toward the end of the lower interval of deposition of the McMurray Formation (Broughton, 2013, 2015), concurrent with extensive configuration of the trough structure on the Devonian unconformity. The central-western area of the trough overlies the 20-kilometer-wide salt scarp, whereas the eastern trough overlies areas of complete salt removal. The westernmost area of the Bitumount Trough coincides with up to a 60-meter erosional cut into the Devonian carbonate strata along the paleovalley (Hauck and others, 2017). The 120-130 $\mathrm{m}$ of salt section removal is indicated by (1) projected contours on regional salt thickness maps (Meijer Drees, 1994), and (2) depth to rim elevation differences of the Bitumount Trough calculated by Broughton $(2013,2015)$.

The eastern trough structure developed during the Late Jurassic concurrent with westward migration of the north-south-oriented salt scarp. During Early Aptian, the salt scarp segment below the northern part of the Athabasca deposit migrated in an arcuate sweep to the northwest, whereas the southern part remained relatively stable and retained a north-south orientation. This scarp migration resulted in formation of the central-western Bitumount Trough above the trailing edge of the salt scarp (fig. 3) and was infilled by deposits of the lower McMurray Formation. Salt removal continued during deposition of the middle and upper McMurray intervals as the salt dissolution front migrated farther north-northwest. This resulted in the adjoined central collapse area along the northern margin of the western Bitumount Trough (Broughton, 2013, 2015).

\section{Devonian Sinkhole Valleys and Breccia Pipes}

Sinkholes, breccia pipes, and breccia pipe-sinkhole complexes are distributed on the pre-Cretaceous paleotopographic surface and were subsequently buried by the sub-Cretaceous unconformity structure (Broughton, 2013). These limestone-walled sinkholes were partially infilled by limestone breccia blocks and subsequently by lower McMurray sediment. Many of the sinkholes are developed along the lower reaches of 3- to 6-kilometer-long sinkhole valleys, such as those along the northern margin of the Bitumount Trough. These sinkhole valleys, oriented to the northeast with secondary orientations to the northwest, were responsive to salt dissolution trends overlying cross-cutting lineaments propagated up-section from differential subsidence and strike-slip displacements of Precambrian blocks (Broughton, 2013).

\section{McMurray Formation (Aptian) Breccia Pipes and Sinkholes}

There was a regional migration of the salt dissolution front to the northwest approximately $200 \mathrm{~m}$ below the northern Athabasca deposit toward the end of lower McMurray deposition. Removal of 80-130 m of salt section triggered differential subsidence of fault blocks consisting of Devonian strata overlain by Aptian lower McMurray strata that configured the western Bitumount Trough (Broughton, 2013, 2015; Barton and others, 2017; Walker and others, 2017). Breccia zones, tens of meters thick and kilometers long, characterize the margins of these displaced Devonian fault blocks (Broughton, 2013). The breccia pipes, rooted at depth to the level of the Prairie Evaporite, often pass upward into sinkholes, resulting in breccia pipe-sinkhole complexes that cross-cut lower McMurray strata (fig. 4). Many lower McMurray Formation sinkholes originated as reactivated Late Jurassic-Early Cretaceous (pre-Aptian) sinkholes upon additional salt removal in the substrate. Some sinkholes are younger and cross-cut middle McMurray Formation strata.

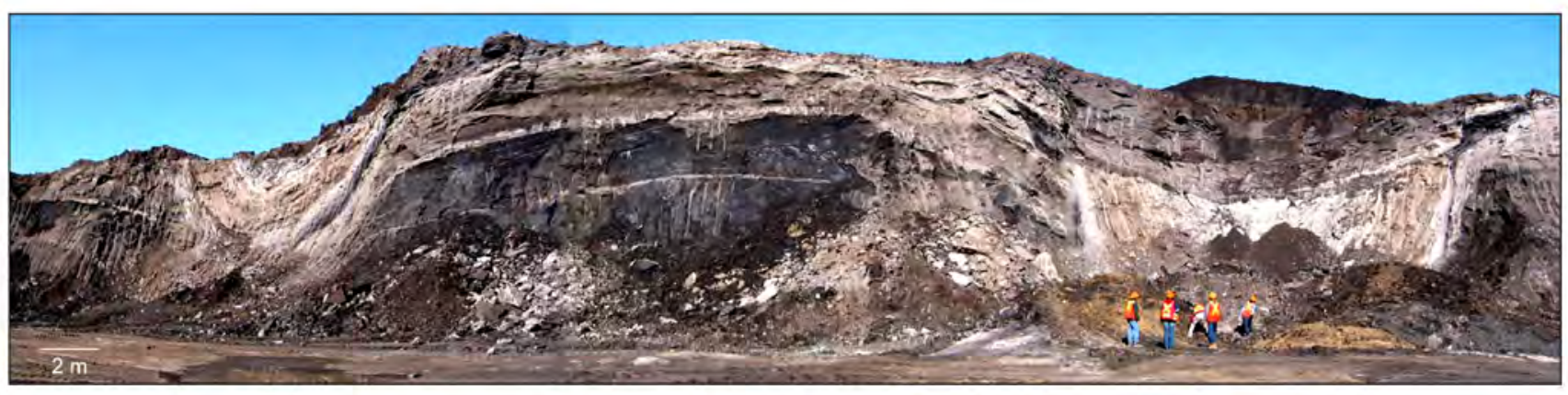

Figure 4. Example of sinkhole "chains" developed during deposition of the lower interval of the McMurray Formation, uncovered at the Aurora North Mine, northern Bitumount Trough. Modified from Broughton (2013). 


\section{Devonian Pseudo-Sinkholes}

Development of ghost-rock karstification, characterized by pseudo-sinkholes, was constrained to the area of the Hammerstone Quarry site in the southwestern Bitumount Trough (fig. 5). The quarry recovers limestone from the 30 - to 40-meter-thick Moberly Member, the uppermost and partially eroded interval of the Devonian Waterways Formation. The preserved Moberly strata consist of massive light grey limestone beds that alternate with chlorite-rich argillaceous limestone intervals. At the quarry, weathered rock profiles developed on the Devonian karstic limestone paleotopographic surface were covered by a glacially thinned mantle (less than 5 m) of McMurray Formation strata.

Weathered rock profiles in the vicinity of the quarry were deepened by slowly moving phreatic groundwater descending along clusters of closely spaced 2- to 10-centimeter-wide joints that cross-cut intensely fractured limestone beds resulting from inter-block collisions upon salt removal in the substrate (Broughton, 2018c, 2019). Descending groundwater mobilized insoluble residues downward from overlying weathered zones of chlorite-rich argillaceous limestone beds. Green-grey colored insoluble residues accumulated as replacement fabrics within decalcified zones of the underlying light grey limestone. As the weathered rock profiles deepened, the joint systems were plugged by insoluble residues, necessitating lateral expansion of the alterite zones. This resulted in distinctive 5- to 20-meter-diameter and 10- to 20-meter-deep, pseudo-sinkhole pods of alterite. These zones retain ghost-rock traces of the original limestone strata (fig. 6).

Distribution of closely spaced joint sets overprinting intensely fracture-shattered limestone was a necessary precursor that permitted the formation of pseudo-sinkholes, in contrast to commonplace salt dissolution-induced collapse sinkholes. The size and shape of these pseudo-sinkholes are superficially similar to sediment-filled dissolution subsidence-collapse sinkholes. However, the strata below these alterite pods lack bed deformation and breccia zones resulting from subsidence and collapse. Although the two karstification processes are genetically unrelated, both sinkholes and pseudo-sinkholes have common linkage to lineament fracture trends responsive to salt removal patterns at depth.

Two types of interrelated joint sets were uncovered by quarry operations: (1) commonplace infilled joints with narrow, 2- to 10-centimeter-wide wall separations without chemically altered surfaces, and (2) solution-enlarged joint channels (fig. 7). The narrow joint sets extend downward for unknown depths into Devonian strata from the overlying solution-enlarged joints at the Devonian unconformity surface. Both joint types are infilled with insoluble residues of chlorite-illite clays and quartz silt sourced from weathering of the overlying chlorite-rich argillaceous limestone beds.
The joint orientations vary within a narrow range: 40-60 degrees with offsets of 130-150 degrees, and north-south at 10 degrees. These orientations at the quarry are consistent with measurements along the Devonian limestone floor of the Athabasca River Valley (Babcock and Sheldon, 1976; Schneider and Grobe, 2013; Schneider and others, 2014). The orientations are also consistent with lineaments on the subglacial topography (Mollard, 1988; Pana and others, 2001). The lineaments are interpreted to parallel northwest and northeast fracture trends, often with strike-slip movements that propagated upward from displaced Precambrian fault blocks into the overlying Devonian strata (Broughton, 2013, 2015, 2018c, 2019).

\section{Discussion and Conclusions: Spatiotemporal Aspects of Salt Dissolution Tectonism, Sinkholes, Pseudo-Sinkholes, and Saline Seeps}

Dissolution removed up to a 130 -meter salt section across thousands of square kilometers toward the end of lower McMurray deposition, and continued during middle interval deposition of the McMurray Formation, resulting in tens of kilometers-long syndepositional trends (Broughton, 2015). Voluminous saline water seeps at the surface may have occurred during deposition (Broughton, 2018b). The salt dissolution tectonism was multi-staged during the Cordilleran orogeny, but erosion of most Tertiary strata overlying the Athabasca Oil Sands resulted in poor preservation and thus, scant evidence for this multi-staged process. The extent of post-Aptian/pre-Quaternary salt dissolution tectonism remains unknown. Nonetheless, it is widely recognized that glacial meltwaters rejuvenated a Quaternary stage of salt dissolution, resulting in saline water seepage to the surface that continues to the present day (Cowie and others, 2014a, b, 2015; Broughton, 2017a, 2018a; Gue and others, 2015, 2017).

Linkage of breccia pipe-sinkhole complexes and differential subsidence of kilometer-scale fault blocks is indicative of multi-stage salt removal events (Broughton, 2013, 2015). This association is lacking across the Hammerstone Quarry area, suggesting that deformation was responsive to a cataclysmic collapse-collision between the fault blocks. Rapid salt dissolution and cataclysmic collapse of the overlying Upper Devonian strata would have resulted in inter-block collisions, fracture-shattering the limestone beds unlike any other area of Devonian strata flooring the Athabasca Oil Sands. The location of these fracture-shattered limestone beds was a uniquely isolated area surrounded by commonplace salt dissolution tectonic events such as collapse-subsidence sinkholes. The shattered rock permitted weathered rock profiles unlike any found elsewhere, resulting in a ghost-rock karst terrain with a new type of pseudo-sinkhole. 

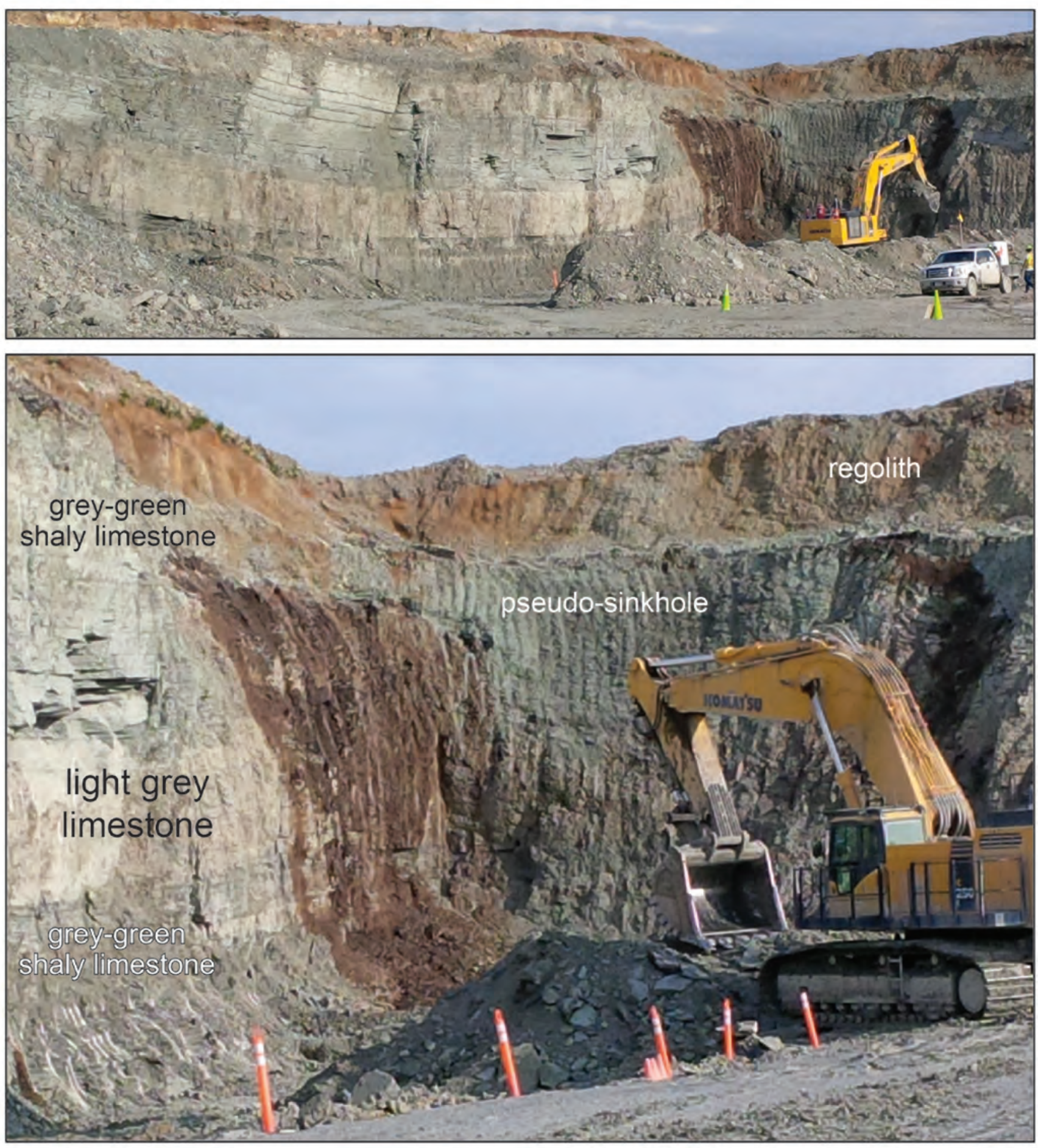

Figure 5. Pseudo-sinkholes developed in a ghost-rock karst terrain in limestone beds of the Upper Devonian Moberly Member, Waterways Formation, uncovered at the Hammerstone Quarry in the southwestern Bitumount Trough. Modified from Broughton (2018c, 2019). 

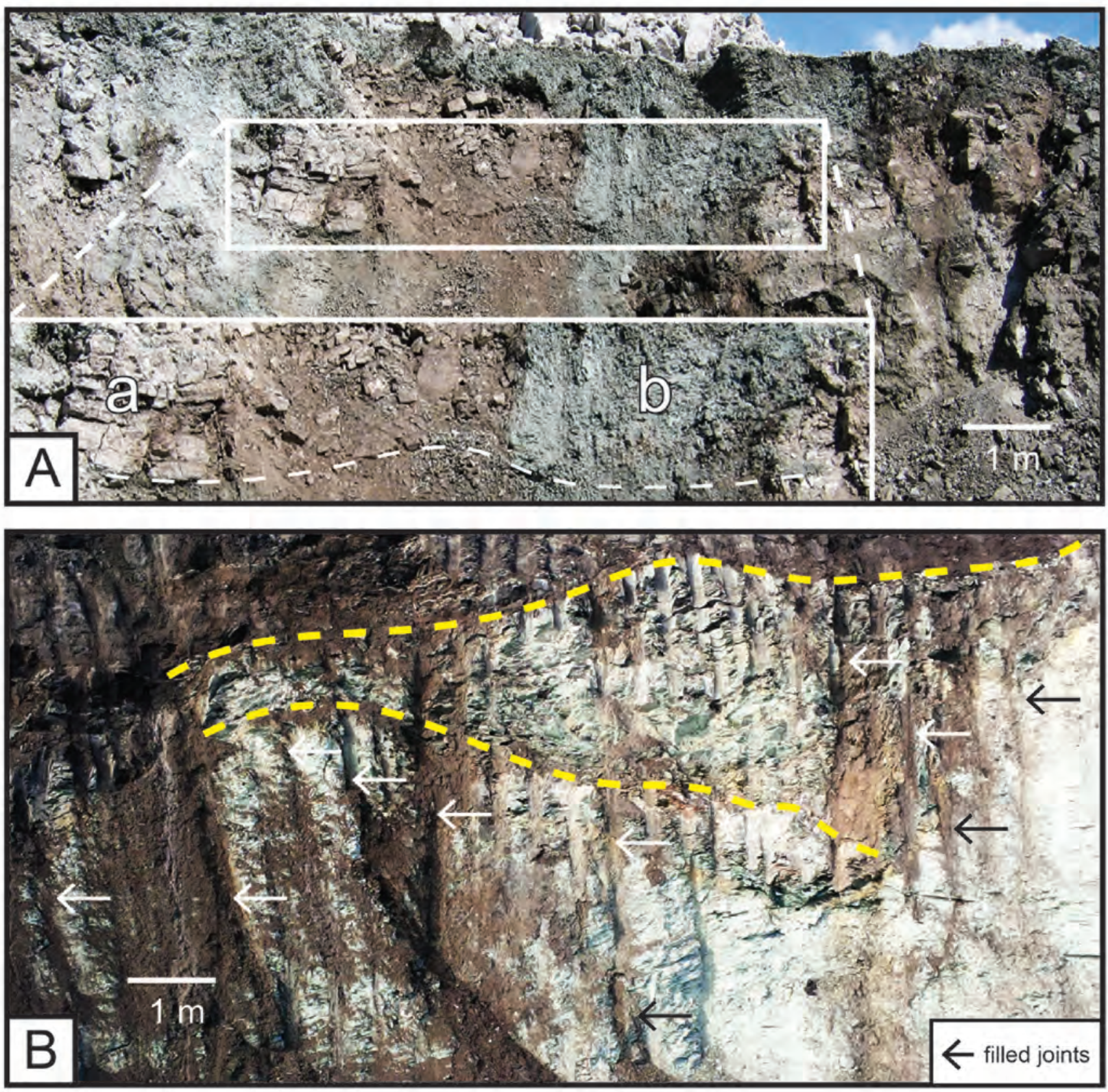

Figure 6. Deeply weathered rock profile resulting in ghost-rock karstification of argillaceous limestone of the Moberly Member, exposed at the Hammerstone Quarry (A). The chlorite-rich insoluble residues were mobilized downward along vertical joints (B, arrows) and infilled areas of calcite dissolution-induced porosity. This resulted in relict outlines of original stratification (a) as ghost-rock fabrics (b). The dashed white line delineates a bed surface and the lateral transition from undisturbed limestone (a) to alterite (b). The weathering profiles result in modest volume shrinkage, with meter-scale pseudo-truncation surfaces (B, yellow dashed lines). 

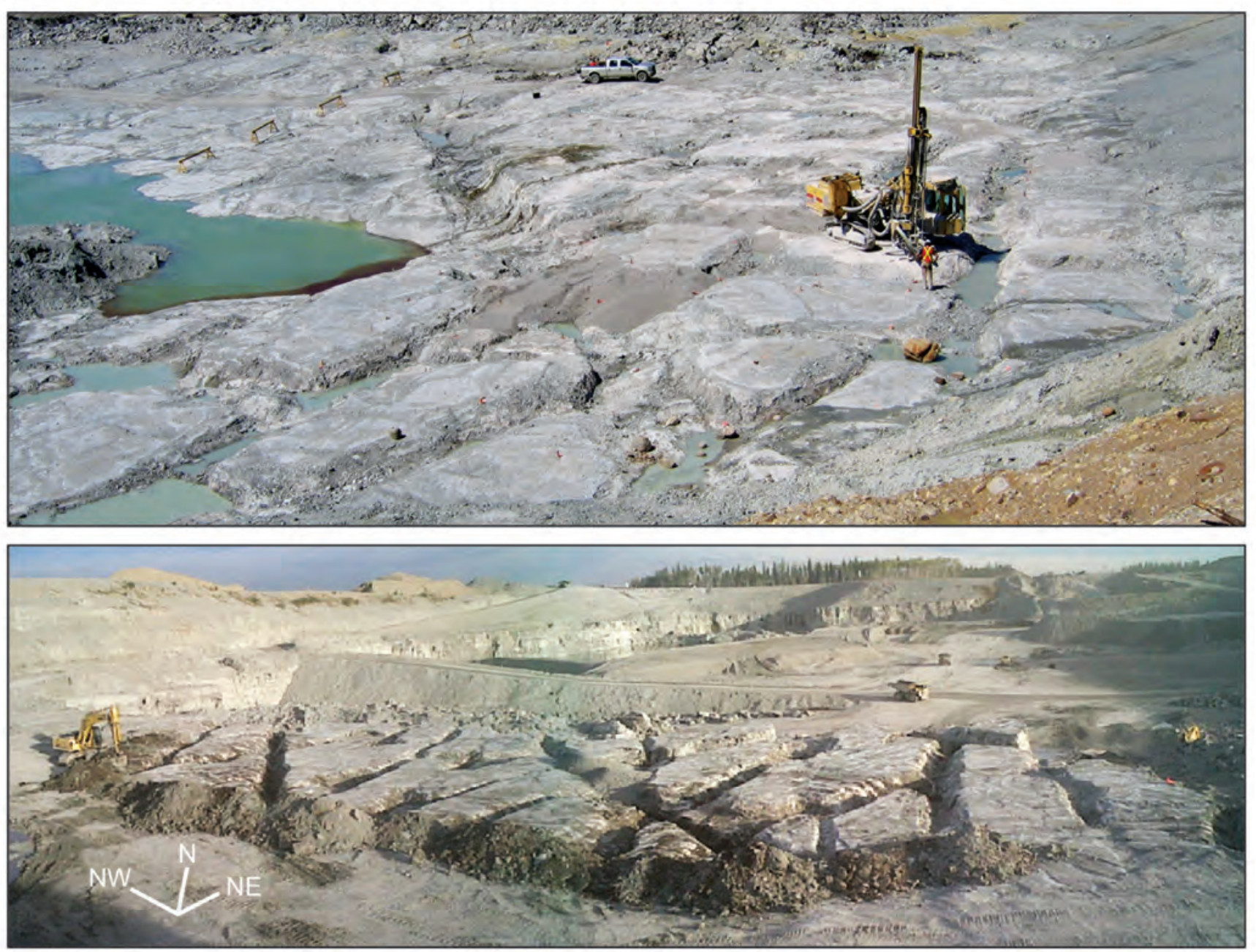

Figure 7. Solution-enlarged joints in the Moberly Member limestone, Waterways Formation (Devonian), exhumed at the Hammerstone Quarry, western Bitumount Trough. The 2- to 3-meter-deep joints were solution-enlarged at the water table and extend downward as narrow 10- to 15-centimeter-wide filled joints. Joint fills of insoluble residues are removed during quarrying to facilitate use of the limestone as crushed rock for road construction. Modified from Broughton (2018c, 2019).

\section{Acknowledgments}

The author expresses his considerable appreciation for reviews provided by Frank Stoakes, Stoakes Consulting Group, Calgary; Mark Barton, Idaho Geological Survey; Robert Mahood, Calgary; and Matthias Grobe, Alberta Geological Survey. These commentaries resulted in a greatly improved article. The Hammerstone Corporation, Calgary, kindly provided photographic images of their operations.

\section{References Cited}

Babcock, E., and Sheldon, L., 1976, Structural significance of lineaments visible on aerial photos of the Athabasca Oil Sands near Fort McKay, Alberta: Bulletin of Canadian Petroleum Geology, v. 24, p. 457-470.

Bachu, S., 1999, Flow systems in the Alberta Basin: Patterns, types and driving mechanisms: Bulletin of Canadian Petroleum Geology, v. 47, p. 455-474.

Bachu, S., and Underschultz, J., 1993, Hydrogeology of formation waters, northeastern Alberta: American Association of Petroleum Geologists Bulletin, v. 77, p. 1745-1768. 
Bachu, S., Underschultz, J., Hitchon, B., and Cotterill, D., 1993, Regional-scale subsurface hydrogeology in northeast Alberta: Alberta Geological Survey, Bulletin 61, 44 p.

Barton, M., Porter, I., O’Bryne, C., and Mahood, R., 2017, Impact of the Prairie Evaporite dissolution collapse on McMurray stratigraphy and depositional patterns, Shell Albian Sands Lease 13, northeast Alberta: Bulletin of Canadian Petroleum Geology, v. 65, p. 175-199.

Birks, S., Moncur, M., Gibson, J., Yi, Y., Fennell, J., and Taylor, E., 2018, Origin and hydrogeological setting of saline groundwater discharges to the Athabasca RiverGeochemical and isotopic characterization of the hyporheic zone: Applied Geochemistry, v. 98, p. 172-190.

Broughton, P.L., 2013, Devonian salt dissolution-collapse breccias flooring the Cretaceous Athabasca Oil Sands deposit and development of lower McMurray Formation sinkholes, northern Alberta Basin, western Canada: Sedimentary Geology, v. 283, p. 57-82.

Broughton, P.L., 2015, Syndepositional architecture of the northern Athabasca Oil Sands deposit, northeastern Alberta: Canadian Journal of Earth Sciences, v. 52, p. 21-50.

Broughton, P.L., 2016, Alignment of fluvio-tidal bars in the middle McMurray Formation-Implications for structural architecture of the Lower Cretaceous Athabasca Oil Sands deposit, northern Alberta: Canadian Journal of Earth Sciences, v. 53, p. 896-930.

Broughton, P.L., 2017a, Collapse of the Devonian Prairie Evaporite karst in the Western Canada Sedimentary BasinStructuration of the overlying Cretaceous Athabasca Oil Sands and regional flow system reversal by subglacial meltwater, in Kuniansky, E.L., and Spangler, L.E., eds., U.S. Geological Survey Karst Interest Group Proceedings, San Antonio, Texas, May 16-18, 2017: U.S. Geological Survey Scientific Investigations Report 2017-5023, p. 92-106.

Broughton, P.L., 2017b, Breccia pipe and sinkhole linked fluidized beds and debris flows in the Athabasca Oil Sands-Dynamics of evaporite karst collapse-induced fault block collisions: Bulletin of Canadian Petroleum Geology, v. 65 , p. $200-234$.

Broughton, P.L., 2017c, Hypogene karst collapse of the Devonian Prairie Evaporite basin in western Canada, in Klimchouk, A., Palmer, A., De Waele, J., Auler, A., and Audra, P., eds., Cave and karst systems of the worldHypogene karst regions and caves of the world: Springer International Publishing, chap. 39, p. 617-632.
Broughton, P.L., 2018a, Orogeny and collapse of the Devonian Prairie Evaporite karst in western Canada-Impact on the overlying Cretaceous Athabasca Oil Sands, in Parise, M., Gabrovsek, F., Kaufmann, G., and Ravbar, N., eds., Advances in karst research-Theory, fieldwork and applications: The Geological Society, London, Special Publication 466, p. 25-78.

Broughton, P.L., 2018b, Salt tectonism and distribution of brackish-water trace fossils in the Cretaceous McMurray Formation, Athabasca Oil Sands, Alberta Foreland Basin: Canadian Journal of Earth Sciences, v. 55, p. 1354-1383.

Broughton, P.L., 2018c, Ghost-rock karstification of Devonian limestone flooring the Athabasca Oil Sands in western Canada: Geomorphology, v. 318, p. 303-319.

Broughton, P.L., 2019, Ghost-rock karstification of Devonian paleotopography at the Hammerstone Quarry site in northeast Alberta [abs.]: 2019 GeoConvention, Canadian Society of Petroleum Geologists, Calgary, $7 \mathrm{p}$.

Cowie, B., James, B., and Mayer, B., 2015, Distribution of total dissolved solids in McMurray Formation water in the Athabasca Oil Sands region, Alberta, Canada-Implications for regional hydrogeology and resource development: American Association of Petroleum Geologists Bulletin, v. 99, p. 77-90.

Cowie, B., James, B., Nightingale, M., and Mayer, B., 2014a, Determination of the stable isotope composition and total dissolved solids of Athabasca Oil Sands reservoir porewater-part 1. A new tool for aqueous fluid characterization in oil sands reservoirs: American Association of Petroleum Geologists Bulletin, v. 98, p. 2131-2141.

Cowie, B., James, B., Nightingale, M., and Mayer, B., 2014b, Determination of the stable isotope composition and total dissolved solids of Athabasca Oil Sands reservoir porewater - part 2. Characterization of McMurray Formation waters in the Suncor-Firebag Field: American Association of Petroleum Geologists Bulletin, v. 98, p. 2143-2160.

Deroo, G., Powell, T., Tissot, B., and McCrossan, R., 1977, The origin and migration of petroleum in the Western Canadian Sedimentary Basin, Alberta - A geochemical and thermal maturation study: Geological Survey of Canada, Bulletin 262, 136 p.

Gibson, J., Fennell, J., Birks, S., Yi, Y., Moncur, M., Hansen, B., and Jasechko, S., 2013, Evidence of discharging saline formation water to the Athabasca River in the oil sands mining region, northern Alberta: Canadian Journal of Earth Sciences, v. 50, p. 1244-1257. 
Grasby, S., and Chen, Z., 2005, Subglacial recharge into the Western Canada Sedimentary Basin — Impact of Pleistocene glaciation on basin hydrodynamics: Bulletin of the Geological Society of America, v. 117, p. 503-514.

Grobe, M., 2000, Distribution and thickness of salt within the Devonian Elk Point Group, Western Canada Sedimentary Basin: Alberta Geological Survey, Earth Sciences Report 2000-02, 12 p.

Gue, A., Grasby, S., and Mayer, B., 2017, Influence of saline groundwater discharge on river water chemistry in the Athabasca Oil Sands region-A chloride stable isotope and mass balance approach: Applied Geochemistry, v. 89, p. $75-85$.

Gue, A., Mayer, B., and Grasby, S., 2015, Origin and geochemistry of saline spring waters in the Athabasca Oil Sands region, Alberta, Canada: Applied Geochemistry, v. 61, p. 132-145.

Hauck, T., Peterson, J., Hathway, B., Grobe, M., and MacCormack, K., 2017, New insights from regional-scale mapping and modelling of the Paleozoic succession in northeast Alberta - Paleogeography, evaporite dissolution, and controls on Cretaceous depositional patterns on the sub-Cretaceous unconformity: Bulletin of Canadian Petroleum Geology, v. 65, p. 87-114.

Hein, F., and Cotterill, D., 2006, The Athabasca Oil Sands-A regional geological perspective, Fort McMurray area, Alberta, Canada: Natural Resources Research, v. 15, p. 85-102.

Hein, F., Dolby, G., and Fairgrieve, B., 2013, A regional geologic framework for the Athabasca Oil Sands, northeastern Alberta, Canada, in Hein, F., Leckie, D., Larter, S., and Suter, J., eds., Heavy-oil and oil-sand petroleum systems in Alberta and beyond: American Association of Petroleum Geologists Bulletin, Studies in Geology, v. 64, p. 207-250.
Holter, M., 1969, Middle Devonian Prairie Evaporite of Saskatchewan: Saskatchewan Department of Mineral Resources Report 123, 134 p.

Jasechko, S., Gibson, J., Birks, J., and Yi, Y., 2012, Quantifying saline groundwater seepage to surface waters in the Athabasca Oil Sands region: Applied Geochemistry, v. 27, p. 2068-2076.

Meijer Drees, N., 1994, Devonian Elk Point Group of the Western Canada Sedimentary Basin, in Mossop, G., and Shetsen, I., eds., Geological atlas of the Western Canada Sedimentary Basin: Canadian Society of Petroleum Geology, Alberta Research Council, p. 129-147.

Mollard, J., 1988, Fracture lineament research and applications on the western Canadian plains: Canadian Geotechnical Journal, v. 25, p. 749-767.

Pana, D., Waters, J., and Grobe, M., 2001, GIS compilation of structural elements in northern Alberta: Alberta Geological Survey, Earth Sciences Report 2001-01, 53 p.

Schneider, C., and Grobe, M., 2013, Regional cross-sections of Devonian stratigraphy in northeastern Alberta (NTS 74D, E): Alberta Geological Survey Open File Report 2013-05, 25 p.

Schneider, C., Mei, S., Haug, K., and Grobe, M., 2014, The sub-Cretaceous unconformity and the Devonian subcrop in the Athabasca Oil Sands area, Townships 87-99, Ranges 1-13, West of Fourth Meridian: Alberta Geological Survey Open File Report 2014-07.

Walker, J., Almási, I., Stoakes, F., Potma, K., and O’Keefe, J., 2017, Hypogene karst beneath the Athabasca Oil SandsImplications for oil sands mining operations: Bulletin of Canadian Petroleum Geology, v. 65, p. 115-146. 


\title{
Abstracts-Geologic Framework of Karst Systems
}

\section{Geologic Framework and Hydrostratigraphy of the Edwards and Trinity Aquifers Within Hays County, Texas}

\author{
By Allan K. Clark ${ }^{1}$ \\ ${ }^{1}$ U.S. Geological Survey, 5563 De Zavala Road, Suite 290, San Antonio, TX 78249. \\ (Email: akclark@usgs.gov)
}

\begin{abstract}
The Edwards and Trinity aquifers are classified as major aquifers by the Texas Water Development Board and are major sources of water in south-central Texas, where Hays County is located. Detailed maps and descriptions of the geologic framework and hydrostratigraphic units (HSUs) of these karstic aquifers in Hays County are needed for water managers to effectively manage groundwater resources in the area. During 2016-18, the U.S. Geological Survey, in cooperation with the Edwards Aquifer Authority, documented the geologic framework and hydrostratigraphy of the Edwards and Trinity aquifers for a large part of Hays County, characterizing approximately 560 square miles of the county. The report includes a 1:24,000-scale hydrostratigraphic map and descriptions of the geology and HSUs in the study area (Clark and others, 2018). In addition, parts of the adjacent upper confining unit to the Edwards aquifer are described. The rocks exposed within the study area comprise outcrops of the Trinity and Edwards Groups and the overlying Washita, Eagle Ford, Austin, and Taylor Groups. The rocks are sedimentary
\end{abstract}

and Cretaceous in age. The principal structural feature in Hays County is the Balcones fault zone, which is the result of late Oligocene and early Miocene-age high-angle normal faulting and fracturing. Hydrostratigraphically, the exposed rocks represent a section of the upper confining unit to the Edwards aquifer, the Edwards aquifer, the upper zone of the Trinity aquifer, the middle zone of the Trinity aquifer, and the upper part of the lower zone of the Trinity aquifer. Complexity in the aquifer system results from a combination of the original depositional history, bioturbation, primary and secondary porosity, diagenesis, fracturing, and faulting.

\section{Reference Cited}

Clark, A.K., Pedraza, D.E., and Morris, R.R., 2018, Geologic framework and hydrostratigraphy of the Edwards and Trinity aquifers within Hays County, Texas: U.S. Geological Survey Scientific Investigations Map 3418, 1 sheet, scale 1:24,000, 11-p. pamphlet, https://doi.org/10.3133/sim3418. 


\title{
Lithologic and Tectonic Controls on the Hydrogeology of the Boone Formation in the Southern Ozarks, Northern Arkansas
}

\author{
By Van Brahana ${ }^{1}$ and Walter Manger ${ }^{2}$ \\ ${ }^{1}$ Emeritus, U.S. Geological Survey. \\ 'Emeritus, University of Arkansas, 222 Gearhart Hall, Department of Geosciences, Fayetteville, AR 72701. \\ ${ }^{2}$ Emeritus, University of Arkansas, 220 Gearhart Hall, Department of Geosciences, Fayetteville, AR 72701. \\ (Email: brahana@uark.edu)
}

\section{Abstract}

The Boone Formation, a karstic interbedded limestone and chert of Early Mississippian age forms the bedrock surface of the Springfield Plateau of the southern Ozarks, typically has high concentrations of penecontemporaneous and later diagenetic chert, composing as much as 70 percent of the entire formation. Limestone between chert layers in the Boone is relatively pure, with highly variable calcisiltites to crinozoan grainstone textures, and can display well-developed, albeit constrained dissolution features. This combination of chert and limestone, mostly occurring as couplets, represents a unique hydrogeologic unit. An explanation for the formation of this limestone/chert couplet interval is presented and may be related to the early tectonic history of the Ouachita orogeny. The ultimate source of the silica in the chert layers is hypothesized to be airborne volcanic ash from island arcs south of the Ouachita Mountains. This is based on scanning electron microscopy, thickness distributions of the chert and limestone couplets, decreasing chert layer continuity away from the volcanic (silica) source, and overall 3-dimensional geometry of the contacts of the limestone/chert couplets. Ash produced pulses of silica into the atmosphere that were progressively deposited with diminishing thickness toward the north and northeast.

Oblique closure of the orogen reactivated preexisting northeast-trending basement faults. Total uplift of the sedimentary succession was as much as 150 meters in the study area, creating orthogonal fracturing with relatively small (about 1 square kilometer), tilted blocks from which the current spring-basin boundaries evolved. The influence of the limestone/chert lithologies and the tectonic aspects of uplift with systematic jointing and faulting resulted in spring discharge from the Boone Formation typically being orders of magnitude less than from the paleokarst springs in Cambrian and Ordovician dolomitic aquifers that are prevalent farther north in the Ozarks of Missouri.

\section{Introduction}

The karst hydrogeology of the Boone Formation in the southern Ozarks is significantly impacted by alternating intervals of areally extensive, bedded chert and limestone. This recurring sequence of lithologies, herein referred to as couplets, is dominant throughout the physiographic region of the Springfield Plateau, the study area in northern Arkansas (fig. 1). The chert within the couplets typically is continuous and thin ( 5 to 10 centimeters) and serves as an effective confining unit in the aquifer. The limestone within the couplets, where it has been exposed to aggressive groundwater and undergone dissolution, serves as the primary water-transmitting component of the formation.

Uplift of the sedimentary-rock cover in the study area has created systematic jointing and faulting. The resulting hydrogeology is compartmentalized and can be quite complex. Often, groundwater problems occur at a scale that lies between regional and site-specific scales, where most previous studies have been undertaken. This paper serves to examine the karst hydrogeology of the Boone Formation at this intermediate scale.

\section{Purpose and Scope}

This paper has two objectives: first, to describe the dominant factors affecting the karst hydrogeology of the Boone Formation, with a focus on the origin of the chert and limestone couplets and the related lithology and uplift associated with Ouachita tectonics, and second, to describe briefly the hydrogeology and karst development of these rocks.

The scope of this paper limits the current discussion to the study area, with limited comments about the Ouachita region. Stratigraphically, the scope is limited to a discussion from the base of the Boone Formation (including the St. Joe Member) to its top. Limited comments are also included about the regolith, derived from the insoluble weathering components of the Boone. 


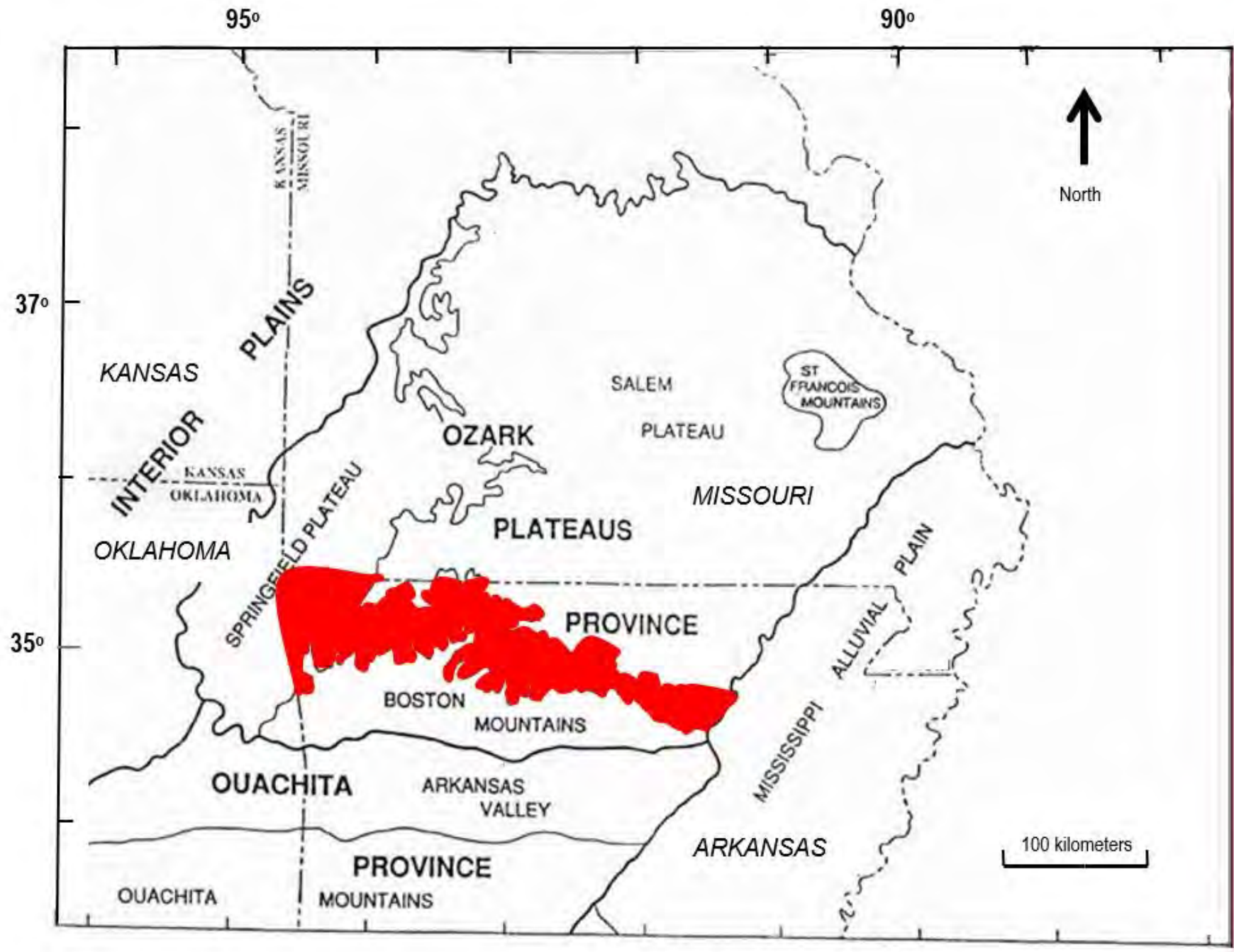

Figure modified from Imes and Emmett (1994)

Figure 1. Generalized map of major physiographic regions of the Ozark Plateaus. The study area of this paper is limited to the Springfield Plateau in northern Arkansas (shaded red).

\section{Lithology}

Distribution of the two dominant lithologies in the Boone Formation is shown on figure 2. Although the ultimate source of the chert has been a matter of conjecture for more than a century (Tarr, 1917; Tarr, 1926; Giles, 1935; Knauth and Epstein, 1976; Niem, 1977; Knauth, 1979; Liner, 1979; Keller and others, 1985; Stanton, 1994; Loomis and others, 1994; Manger and Shelby, 2000; and Mazzullo and others, 2009), recent research at the University of Arkansas by Cains and others (2016) and Philbrick and others (2016), indicates that a volcanic-ash source is most consistent with observed data. Attributes of the chert between the upper and lower divisions of the formation reflect highstand and regression of sea level, with aerobic conditions more common in the upper part of the Boone and anaerobic conditions present in the lower part. The chert in the upper Boone typically is white to light grey and contains a much greater percentage of carbonate. The upper Boone also has a greater preponderance of fossils that are preserved as detailed molds of shallow marine organisms. The interpretation that these are shallow-water environments is based on the presence of benthonic fossils with calcareous shells and supporting structures, as well as related carbonate detritus. Meteoric fresh water circulating through the sediments and recently indurated sedimentary rocks appears to be the dissolving fluid, creating not only the karst voids in the limestone part of the couplets, but dissolving the carbonate fossils in the chert of the couplets and leaving molds. 


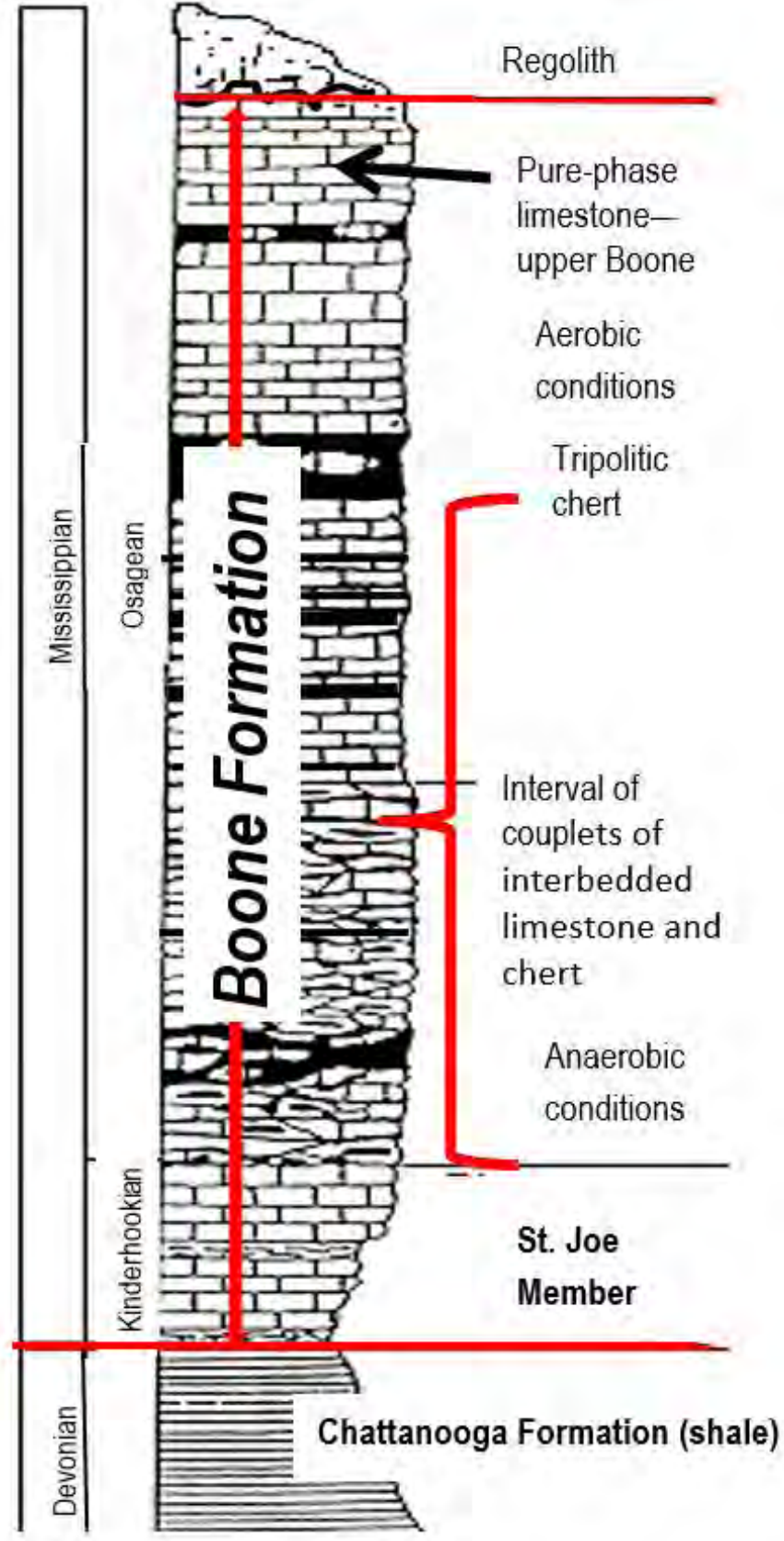

Figure 2. General lithologic attributes of the Boone Formation in northern Arkansas. Chert is shown as solid black layers and lenses within the limestone.
Limestone deposition in the study area was widespread across a broad, shallow platform (the Burlington Shelf) extending northward into Missouri (Shelby, 1986; Kresse and others, 2014). Intervals at the top and bottom of the formation generally consist of pure-phase limestones and may have sinkholes and related surficial landforms that are rare in most of the intervening layers of the Boone where chert is dominant. Throughout the couplet interval, limestone production in shallow conditions appears to be continuous, interrupted by pulses of silica deposition that overwhelm limestone production (carbonate factory). This conceptual model allows for mobilization of some of the silica to be redeposited by groundwater flow as later diagenetic chert in the upper Boone, although in the couplets, the thin (generally less than 10 centimeters), widespread (typically one kilometer or more) chert intervals are more consistent with deposition from above, rather than laterally. In the lower Boone (fig. 3A-3B), penecontemporaneous chert is dominant and limestone lithologies have graded bedding consisting of tightly packed bryozoan-crinozoan packstones and grainstones exhibiting fining-upwards sequences (Shelby, 1986).

In addition to the cyclicity of the pulses of ash, sea level and subaerial exposure played a key role in aspects of the lithology and in the dissolution that enhanced karst development (fig. 3B). Atmospheric transport and deposition of volcanic ash, measured as total thickness of silica (novaculite and chert) deposited, decreased toward the north and northeast (fig. 4), with the deposition in the south starting earlier. The thickest deposits (about 300 meters in the Arkansas Novaculite) are closest to the silica source, as well as proximate to the welded tuffs of the Hatton Tuff Lentil (Loomis and others, 1994; Cains, 2019). To the north in the study area, continuous thin layers and nodules of chert compose less than 100 meters total (Liner, 1979). Farther north in Iowa (Avcin and Koch, 1979) and Illinois (Biggs, 1957), and northeast in Kentucky and Tennessee, total thickness ranges from less than 5 to 10 meters. 


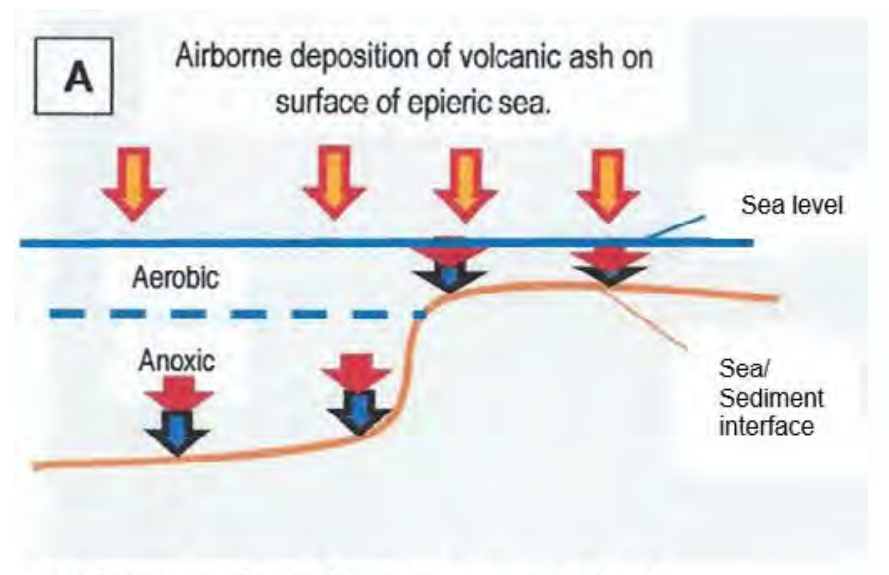

Continuous settling of limestone generated by the "carbonate factory" is overlain and intercalated with pulses of ash (as a gel) on the sea/sediment surface (tan contact); cyclicity of ash production repeats couplets, whereas duration and intensity control thickness and continuity.

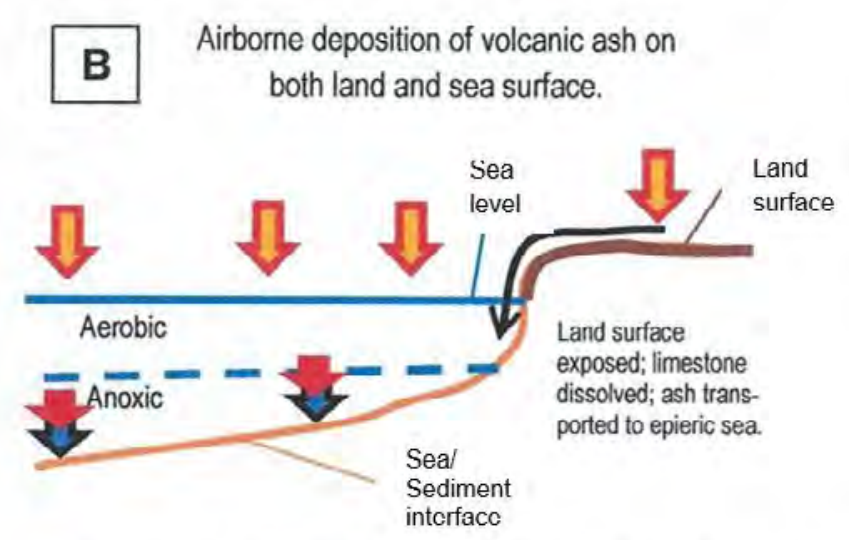

Lower sea level exposes previous shallow-water couplets. Subaerial exposure initiates limestone dissolution where favorable environments occur, creating paleokarst. Ash is transported to the sea. In deeper water, limestone/chert couplets form as shown in figure $3 \mathrm{~A}$.

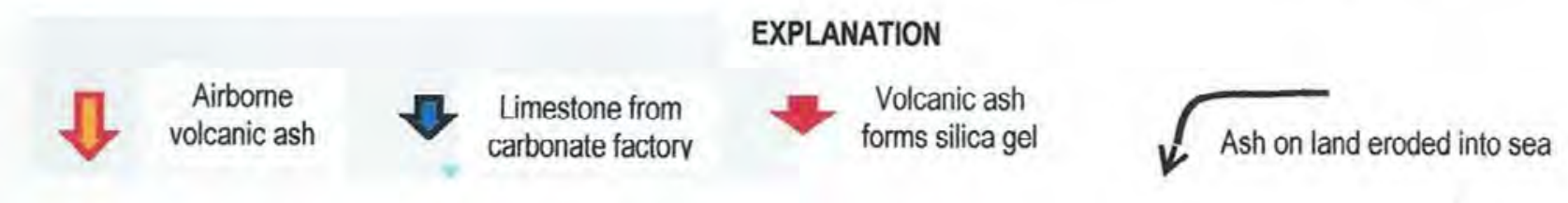

Figure 3. A, Conceptual model for the formation of the limestone/chert couplets in the Boone Formation during highstand of sea level in the study area. B, Conceptual model showing variations in development of paleokarst in the limestone part of the couplets.

In abbreviated terms, the hypothesis for the formation of the couplets in the study area involves volcanic ash falling on a shallow epieric sea and sinking of the ash to form a gel on top of limestone sediments generated from the carbonate factory. This allows the formation of thin layers of chert from recurring pulses of volcanism (fig. 5) that can be widespread areally and result in globular to planar contacts between lithologies (figs. 5-7), depending on induration. Continuous carbonate production results in variable percentages of carbonate detritus within the chert. The couplet sequence starts anew with shutting down of the volcanic pulse, allowing new limestone to be deposited atop the silica gel or chert if induration has occurred. Lithologies formed in the anoxic zone are dark grey to black (fig. 7) and do not truncate existing sedimentary features. Lithologies formed in shallower aerobic zones are generally light grey to white (figs. 5 and 6), and display shallow water depositional features (Shelby, 1986) and existing structures characteristic of subaerial exposure and weathering.

The presence of generally small but variable percentages of carbonate sediment within most of the chert is consistent with ongoing carbonate production. North of the study area in Iowa and Illinois, chert generally is not found in continuous layers, but occurs as discontinuous nodules that commonly occupy discrete bedding planes. 


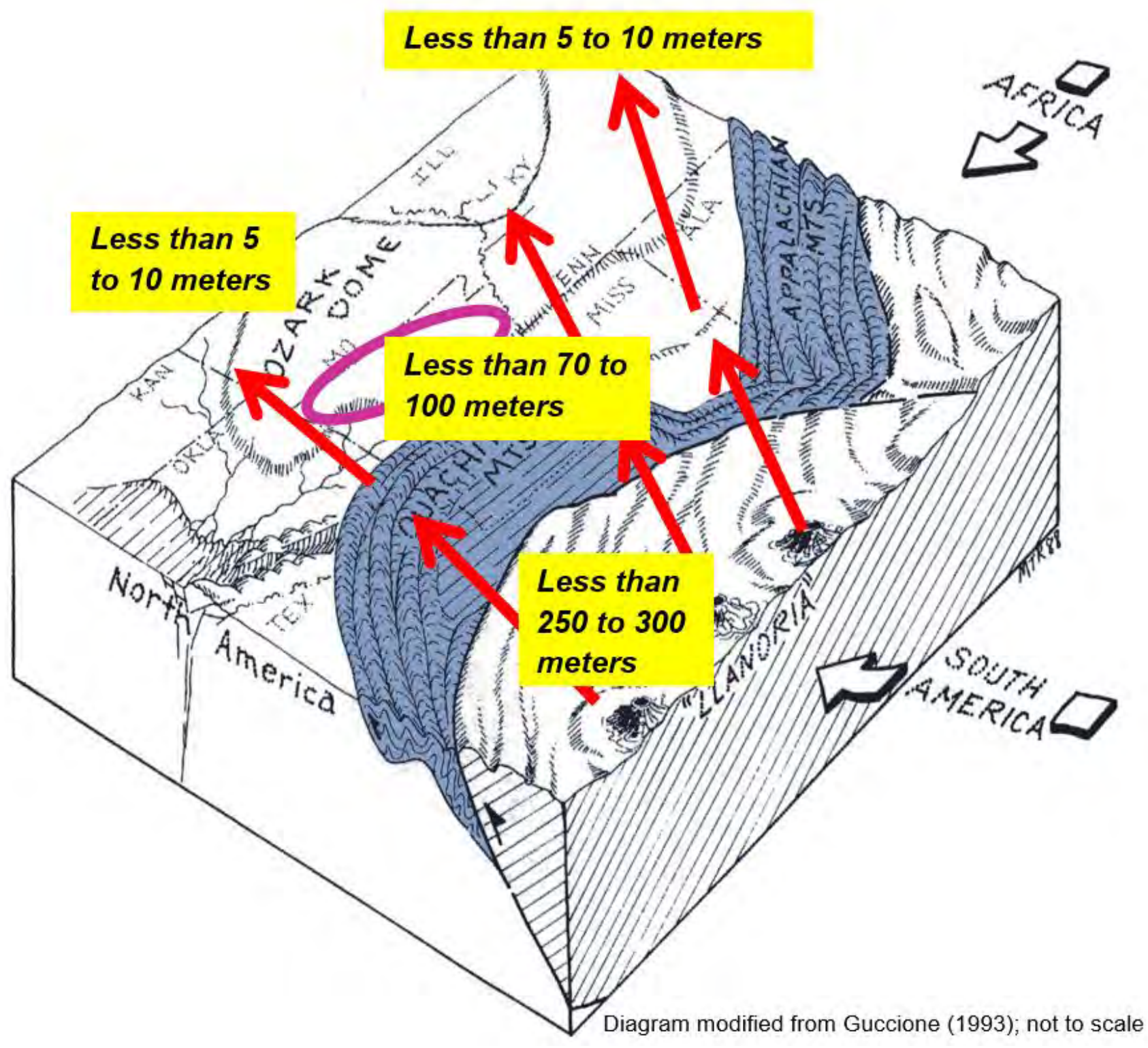

Figure 4. Block diagram showing decrease of total chert thickness with respect to the location of the island arcs above the subducting North American plate during the Ouachita orogeny. General direction of atmospheric deposition is toward the north and northeast, as indicated by the arrows (red). Total chert thickness in meters, is shown inside the boxes (yellow). Approximate location of the study area is shown by ellipse (purple). Approximate width of north edge of block is 1,200 kilometers. Source of compressive tectonic plate motion is shown along eastern and southern edges of block. 


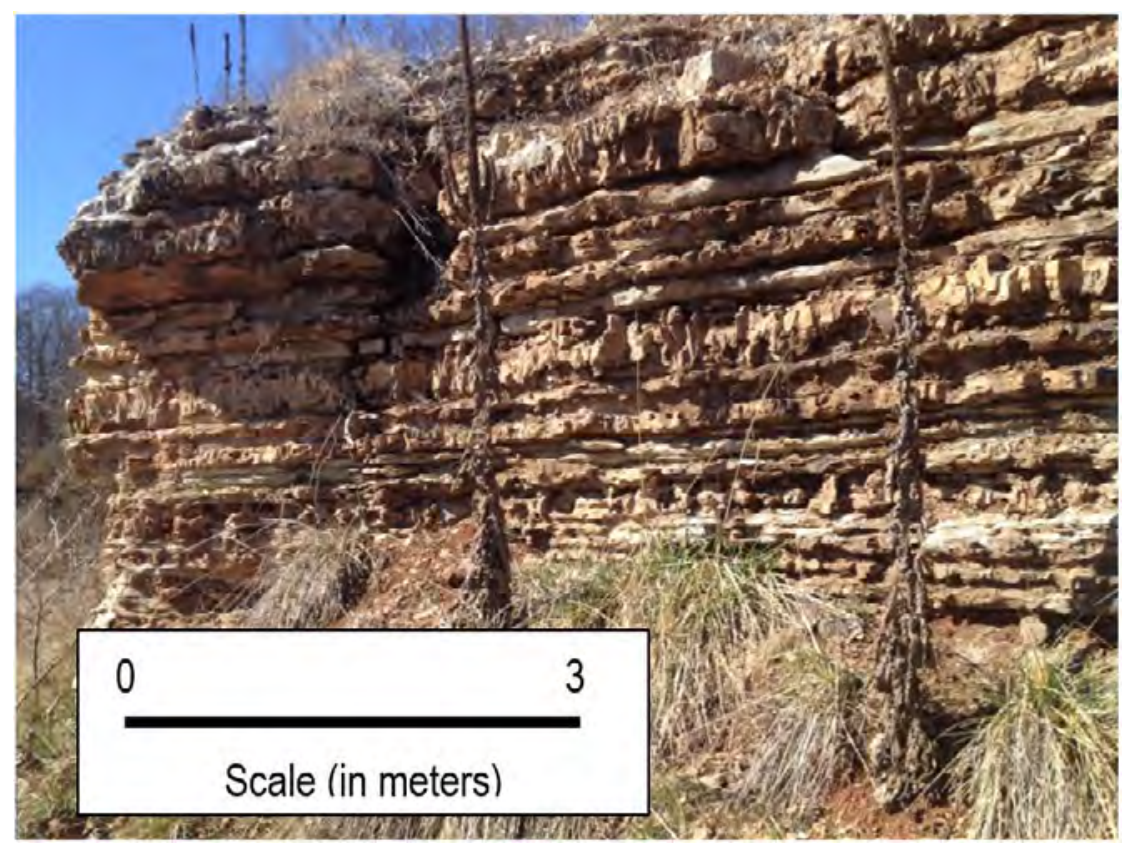

Figure 5. Photograph showing vertical succession of weathered limestone/chert couplets in outcrop, illustrating thin, wide continuous couplets with contacts that vary from planar to lobate. Photo taken by Van Brahana, University of Arkansas, 2010, near the southern boundary of Bella Vista, Arkansas.

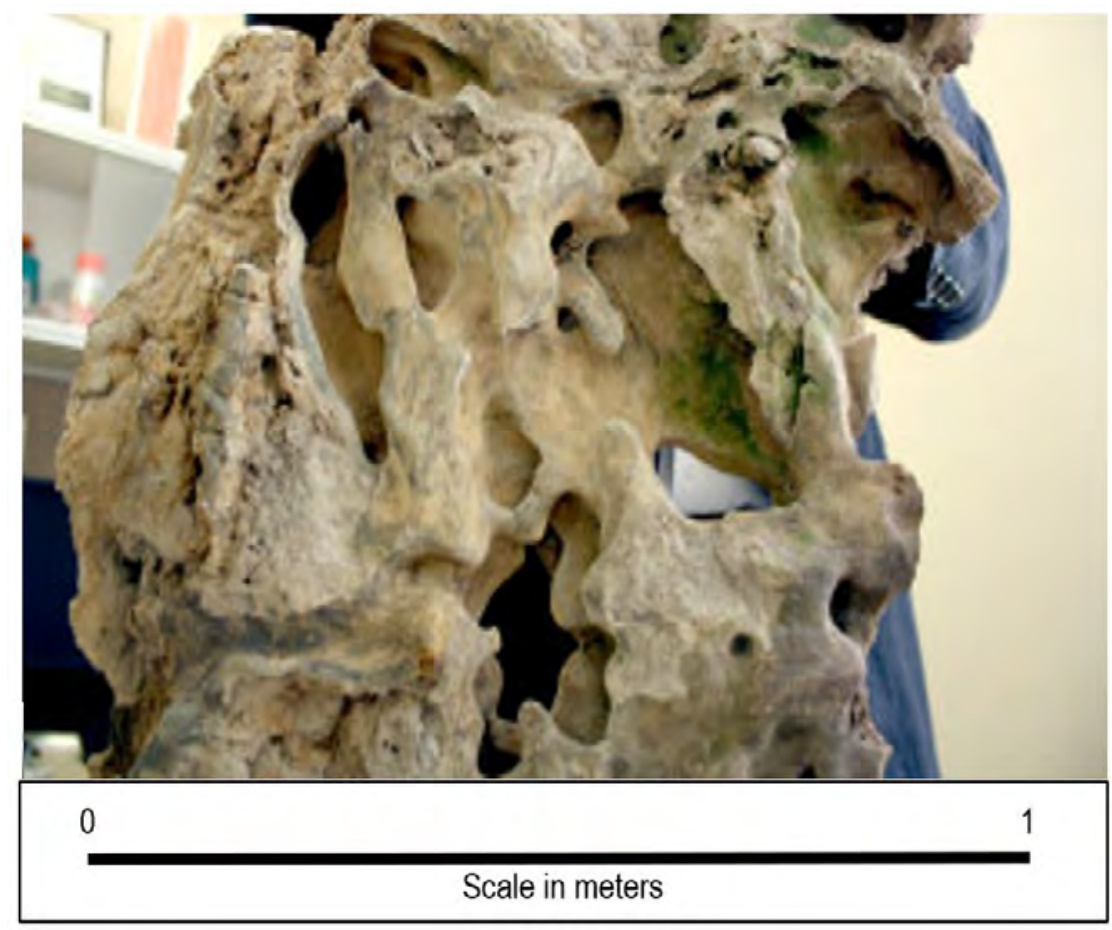

Figure 6. Weathered slab of chert showing voids where limestone was completely dissolved, illustrating the three-dimensional lobate shape of the two different lithologies that formed the couplets. This contact is interpreted as being pre-induration of the silica gel and the carbonate sediment. Planar contacts are thought to have been indurated and thus more rigid. Orientation of slab shows underside of bedding plane. 


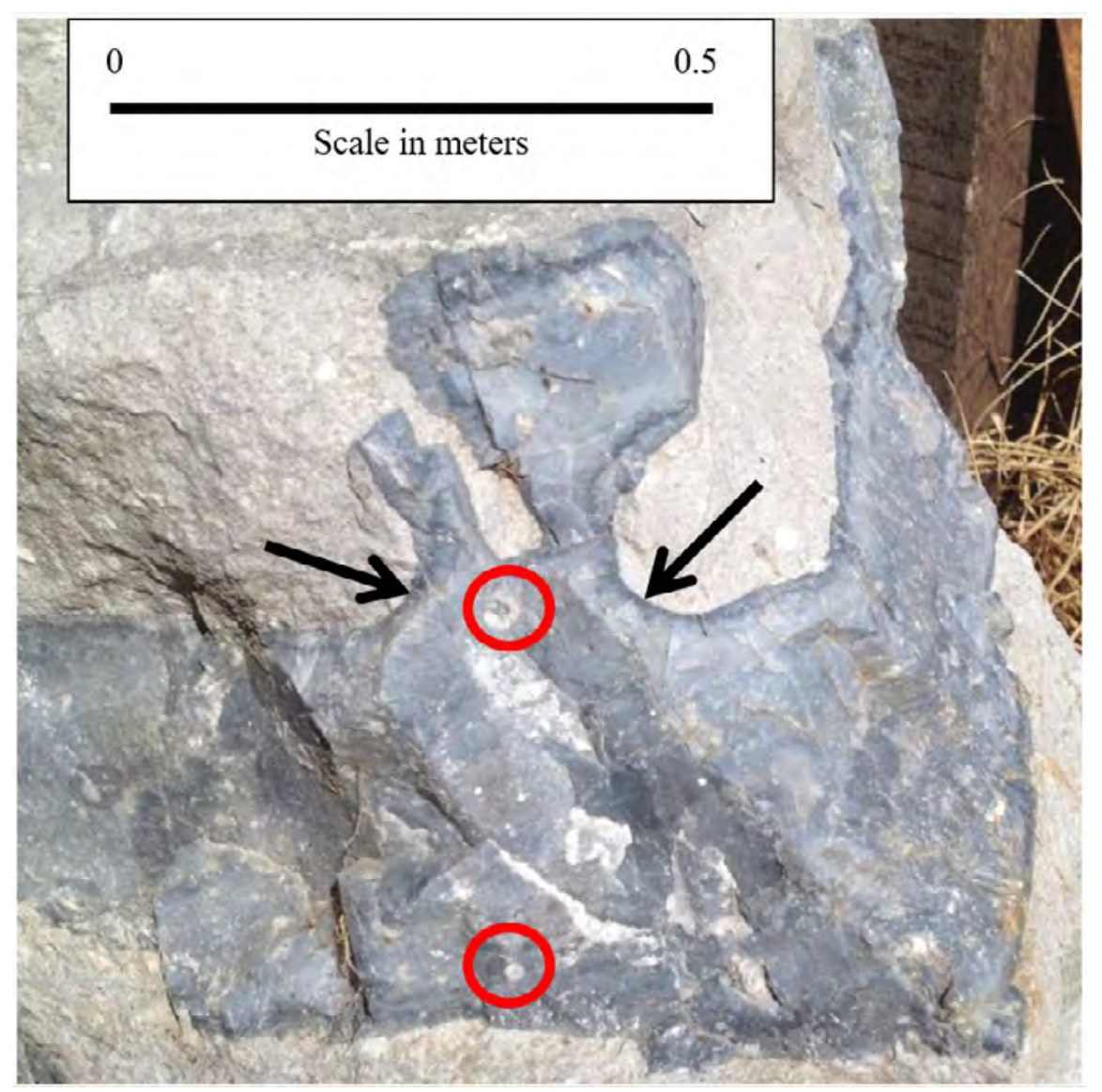

Figure 7. Unweathered block of chert and limestone from a quarry wall near the Beaver Reservoir dam. The environment of deposition is interpreted as anoxic and shows the lobate structure of the limestone (light grey) and chert (darker grey) along their contact (arrows). The lithologies have not been exposed to subaerial weathering. Crinoid stems of calcium carbonate (light grey) are shown within the red circles.

\section{Tectonics}

Tectonically, uplift created systematic joints and faults in the sedimentary-rock cover overlying the reactivated basement faults associated with the closure of the Ouachita orogen. These compressive tectonic forces also generated the volcanic ash, a result of subduction of the North American plate beneath the overriding South American plate (Thomas, 1976; Hudson, 2000). Occurrences of welded tuff are found nearby, south of the Arkoma Basin (Neim, 1977; Loomis and others, 1994). The steps in the evolution of this far-field uplift are simplified into the conceptual model described below.

The compressive closure of the tectonic plates was initiated first from the east, moving progressively westward as oblique closure (Thomas, 1976). Because the igneous rocks of the crystalline basement are much stronger than the overlying sedimentary rocks, reactivation of previously faulted basement rocks focused most of the compressive stress vertically. Maximum compressive force occurred in the south, and resulting uplift (foreland bulge) was greatest in the area of the Buffalo National River. Zones between the faults were uplifted to varying levels, from tens of meters in the south to as much as 150 meters of uplift in northern Arkansas. Supplemental evidence consistent with this includes abrupt elevation changes of contacts across the deep-seated, northeast-trending basement faults from observed gravity, magnetic, and drillhole data, and displacement of outcrop patterns (fig. 8).

Associated with the uplift, the sedimentary rocks above the crystalline basement were exposed to stresses that fractured and tilted them slightly, accommodating re-equilibration with greater space allowance. The couplets of limestone/chert responded with orthogonal joints and faults, which allowed recharge from the surface to move into the rock mass and preferentially dissolve the most favorable facies within the stack of sedimentary rocks. The chert layers controlled vertical confinement and perching of the groundwater, and the major joints and faults defined the lateral boundaries of spring basins. Groundwater moves downgradient in the resulting direction (dip) of the tilted stack, typically to small-magnitude springs at the lower, distal end of the flow system. 


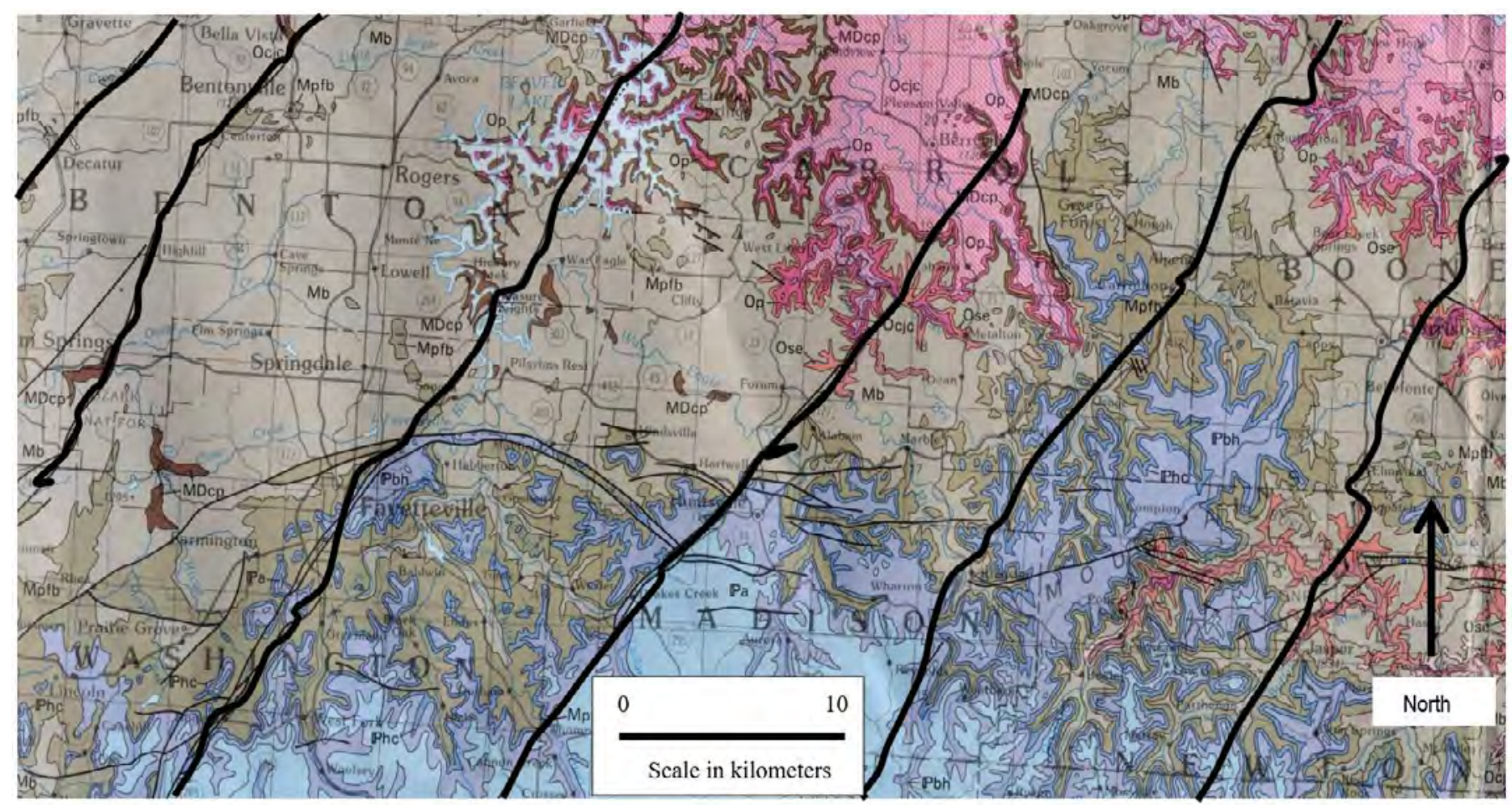

Geology modified from Haley and others, 1993

Figure 8. Approximate location of northeast-trending basement faults (shown as heavy black lines), controlling the asymmetrical outcrop patterns of rocks in the area of uplift, causing the foreland bulge in northern Arkansas. Other faults are shown with thinner black lines. Ordovician rocks are shown in shades of pink, Mississippian rocks are shown in shades of brown, and Pennsylvanian rocks are shown in shades of blue.

\section{Hydrogeology}

The presence of significant amounts of chert has several implications for the hydrogeology of the southern Ozarks, including markedly lower non-karst permeability, the capability to perch and confine flow in vertical dimensions, and the ability to redirect flow based on a tilted-block model (Brahana, 1997). These structural features resulted in numerous small-discharge springs. With changing water levels, different stacked zones of paleokarst are encountered, thereby potentially changing flow boundaries and flow directions (Brahana, 2011). Although spring discharge from this interval of the Boone is low, typically within 5 to 25 liters per minute during drought conditions, many springs continue flowing throughout the year, indicating there is a modicum of slow-release storage from the regolith. Boone Formation springs resurge from shallow groundwater flow paths through the epikarst and the underlying karstified limestones (fig. 9). Springs that resurge from the Boone with discharges greater than about 140 liters per second at base flow typically have captured surface streams where they flow across faults and are diverted into the subsurface.

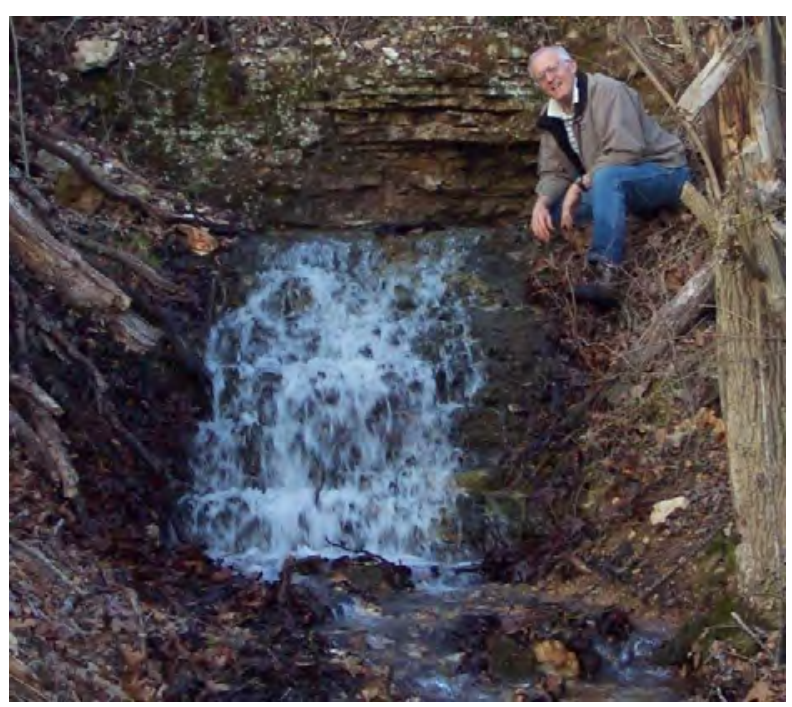

Figure 9. Hydrogeologic effect of limestone/chert couplets on springflow from the Boone Formation. Springflow resurges from dissolved limestone and is perched on underlying chert. It cascades over six couplet intervals in this photograph from the Savoy Experimental Watershed. When water levels in the Boone recede below the current level of resurgence, springflow ceases. Photo taken by Phil Hays, U.S. Geological Survey, 2010. 


\section{Summary}

The karst hydrogeology of the Boone Formation in northern Arkansas is strongly controlled by recurring intervals of areally extensive bedded limestone and chert couplets. The chert within the couplets typically is thin and serves as an effective confining unit for groundwater movement. The limestone within the couplets, where it has been exposed to chemically aggressive groundwater, can be karstified by dissolution and thus serves as the primary water-transmitting zone in the aquifer. Many of the chert layers are laterally extensive, which has the effect of controlling the location of spring discharge. Uplift of the sedimentary-rock cover in the study area has created systematic jointing and faulting, facilitating recharge to the major water-transmitting zones. The resulting hydrogeology is compartmentalized and can be quite complex, depending on the conditions that created the paleokarst. Major joints and faults commonly serve as boundaries for groundwater basins, either as high-permeability zones, or if they have been occluded by sedimentation or debris, as groundwater dams. Evaluation of spring discharge at low flow provides a tool to help determine the size of the recharge area of the groundwater basin. Where the Boone occurs, losing stream reaches are common sites of surface-water piracy, and further compound the complexity of groundwater flow.

Hydrogeologically, regional studies and limited-scale, site-specific studies provide some understanding at these scales, but the hydrogeology at an intermediate scale, where most environmental problems occur, is not well defined. Large-scale studies rely on lumping regional data, and small-scale studies commonly focus on site-specific details that are limited to property boundaries. The complexity of groundwater flow in the Boone Formation justifies a more holistic approach, one that is weighted to field studies of the natural system at meaningful and appropriate scales.

\section{Selected References}

Avcin, M.J., and Koch, D.L., 1979, The Mississippian and Pennsylvanian (Carboniferous) Systems in the United States-Iowa: U.S. Geological Survey Professional Paper 1110-M, 13 p.

Biggs, D.L., 1957, Petrology and origin of Illinois nodular cherts: Illinois State Geological Survey Circular 245, 25 p.

Brahana, J.V., 1997, Rationale and methodology for approximating spring-basin boundaries in the mantled karst terrane of the Springfield Plateau, northwestern Arkansas, in Beck, B.F., and Stephenson, J.B., eds., Sixth Multidisciplinary Conference on Engineering Geology and Hydrogeology of Karst Terranes: Rotterdam, A.A. Balkema, p. $77-82$.
Brahana, V., 2011, Ten relevant karst hydrogeologic insights gained from 15 years of in situ field studies at the Savoy Experimental Watershed, in Kuniansky, E.L., ed., U.S. Geological Survey Karst Interest Group Proceedings, Fayetteville, Arkansas, April 26-29, 2011: U.S. Geological Survey Scientific Investigations Report 2011-5031, p. 132-141.

Cains, J.M., 2019, Geochemical analysis of Mississippian cherts and Devonian-Mississippian novaculites, southern midcontinent region: Fayetteville, University of Arkansas, unpublished M.S. thesis, 74 p., https://scholarworks.uark.edu/etd/3248.

Cains, J.M., Potra, A., and Pollock, E.D., 2016, Lower Mississippian chert development, southern midcontinent region: Journal of the Arkansas Academy of Science, v. 70, article 12, p. 59-63.

Giles, A.W., 1935, Boone chert: Geological Society of America Bulletin, v. 46, p. 1814-1867.

Guccione, M.J., 1993, Geologic history of Arkansas through time and space: National Science Foundation, Arkansas Regional Studies Center, unnumbered report, $66 \mathrm{p}$.

Haley, B.R., Glick, E.E., Bush, W.V., Clardy, B.F., Stone, C.G., Woodward, M.B., and Zachry, D.L., 1993, Geologic map of Arkansas: Arkansas Geological Commission, scale 1:500,000.

Hudson, M.R., 2000, Coordinated strike-slip and normal faulting in the southern Ozark dome of northern ArkansasDeformation in a late Paleozoic foreland: Geology, v. 28, p. 511-514.

Imes, J.L., and Emmett, L.F., 1994, The geohydrology of the Ozark Plateaus aquifer system in parts of Missouri, Arkansas, Oklahoma, and Kansas: U.S. Geological Survey Professional Paper 1414-D, 127 p.

Keller, W.D., Stone, C.G., and Hoersch, A.L., 1985, Textures of Paleozoic chert and novaculite in the Ouachita Mountains of Arkansas and Oklahoma and their geological significance: Geological Society of America Bulletin, v. 96, p. 1353-1363.

Knauth, L.P., 1979, A model for the origin of chert in limestone: Geology, v. 7, p. 274-277.

Knauth, L.P., and Epstein, S., 1976, Hydrogen and oxygen isotope ratios in nodular and bedded cherts: Geochimica et Cosmochimica Acta, v. 40, p. 1095-1108. 
Kresse, T.M., Hays, P.D., Merriman, K.R., Gillip, J.A., Fugitt, D.T., Spellman, J.L., Nottmeier, A.M., Westerman, D.A., Blackstock, J.M., and Battreal, J.L., 2014, Aquifers of Arkansas_-Protection, management, and hydrologic and geochemical characteristics of groundwater resources in Arkansas: U.S. Geological Survey Scientific Investigations Report 2014-5149, 334 p., http://dx.doi.org/10.3133/sir20145149.

Liner, J.L., 1979, Lithostratigraphy of the Boone Limestone (Lower Mississippian), northwest Arkansas: Fayetteville, University of Arkansas, unpublished M.S. thesis, 88 p.

Loomis, J., Weaver B., and Blatt, H., 1994, Geochemistry of Mississippian tuffs from the Ouachita Mountains, and implications for the tectonics of the Ouachita orogeny, Oklahoma and Arkansas: Geological Society of America Bulletin, v. 106, p. 1158-1171.

Manger, W.L., and Shelby, P.R., 2000, Natural-gas production from the Boone Formation (Lower Mississippian), northwest Arkansas: Oklahoma Geological Survey Circular 101, p. 163-169.

Mazzullo, S.J., Wilhite, B.W., and Woolsey, I.W., 2009, Petroleum reservoirs within a spiculite-dominated depositional sequence - Cowley Formation (Mississippian Lower Carboniferous), south-central Kansas: American Association of Petroleum Geologists Bulletin, v. 93, no. 12, p. 1649-1689.
Niem, A.R., 1977, Mississippian pyroclastic flows and ash-fall deposits in the deep-marine Ouachita flysch basin, Oklahoma and Arkansas: Geological Society of America Bulletin, v. 88, p. 49-61.

Philbrick, J., Pollock, E., and Potra, A., 2016, Comparison of the elemental geochemistry of the Arkansas Novaculite and the Boone chert in their type regions, Arkansas: Journal of the Arkansas Academy of Science, v. 70, article 31, p. 184-189.

Shelby, P.R., 1986, Depositional history of the St. Joe and Boone Formations in northern Arkansas: Journal of the Arkansas Academy of Science, v. 40, article 22, p. 67-71.

Stanton, G.P., 1994, Processes and controls affecting anisotropic flow in the Boone-St. Joe aquifer in northwestern Arkansas: Fayetteville, University of Arkansas, unpublished M.S. thesis, 230 p.

Tarr, W.A., 1917, Origin of chert in the Burlington Limestone: American Journal of Science, v. 44, p. 409-452.

Tarr, W.A., 1926, The origin of chert and flint: University of Missouri Studies, v. 1, no. 2, 54 p.

Thomas, W.A., 1976, Evolution of Appalachian-Ouachita continental margin: Journal of Geology, v. 84, no. 3, p. 323-342. 


\title{
Hypogenic Origin of Paleokarst Caves in the Lower-Middle Ordovician in the Southern Tahe Oilfield, Tarim Basin, Northwest China
}

\author{
By Heng Zhang ${ }^{1,2}$ Zhongxian Cai, ${ }^{1,2}$ Wenge $\mathrm{Hu}^{3}$ and Xinbian $\mathrm{Lu}^{3}$ \\ ${ }^{1}$ China University of Geosciences, Key Laboratory of Tectonics and Petroleum Resources of Ministry of Education, Wuhan 430074, China. \\ ${ }^{2}$ China University of Geosciences, School of Earth Resources, Wuhan 430074, China. \\ ${ }^{3}$ Northwest Oilfield Company, SINOPEC, Urumqi, Xinjiang 830011, China. \\ (Email: cughzhang@163.com)
}

\begin{abstract}
Paleokarst cave reservoirs in Lower-Middle Ordovician limestones in the northern Tahe area, Tarim Basin, northwest China, are formed by epigenic karst processes, which are characterized by shallow meteoric flow in unconfined settings. Therefore, these paleocaves were traditionally thought to be developed within 100 meters of the regional unconformities. Recently, a deep-seated paleokarst cave system has been shown to occur in Lower-Middle Ordovician limestones in the southern Tahe Oilfield (Lu and others, 2017). An integrated approach was used to characterize the caves by combining seismic data with well drilling data and available cores. Carbon, oxygen, and strontium isotope geochemical characteristics of, and fluid inclusions in, the cave-filling calcite in the Tahe Oilfield were investigated. By comparing with previous studies in the northern Tahe Oilfield, the origin of the paleokarst caves in the southern Tahe Oilfield was determined. An extensive cave system, hosted in the lower part of the Upper Yingshan Formation in the southern Tahe Oilfield, was present from 160 to 351 meters below the unconformity. Distinguishable from the integrated conduit system in the northern Tahe Oilfield, only isolated voids were discovered in the southern Tahe Oilfield. In addition, the cave-filling calcite in the southern Tahe Oilfield was
\end{abstract}

influenced not only by meteoric water possibly derived from the northern Tahe Oilfield during the early Hercynian orogeny (late Paleozoic, about 359 million years ago), but also by thermal water from the second phase of the middle Caledonian orogeny (middle Paleozoic, about 446 million years ago) to the early Hercynian orogeny. The paleokarst caves in the southern Tahe Oilfield are interpreted as resulting from hypogene speleogenesis (deep circulation of meteoric water and thermal water) induced by the flower-like structure of a strike-slip fault system in the lower part of the Upper Yingshan Formation in confined karst settings. This study indicates that it is still possible for ascending fluids to form large fault-controlled paleokarst caves in the subsurface, which should be considered as significant petroleum-bearing targets in future exploration.

\section{Reference Cited}

Lu, X.B., Wang, Y., Tian, F., and others, 2017, New insights into the carbonate karstic fault system and reservoir formation in the Southern Tahe area of the Tarim Basin: Marine and Petroleum Geology, v. 86, p. 587-605. [Also available at https://www.sciencedirect.com/science/article/ abs/pii/S0264817217302301.] 


\title{
Abstracts-Geophysical Methods in Karst Preferential Groundwater Flow in Karst Terrane Inferred From Geoelectric Measurements
}

\author{
By Scott Ikard ${ }^{1}$ and Emily Pease ${ }^{1}$
}

\author{
${ }^{1}$ U.S. Geological Survey, 1505 Ferguson Lane, Austin, TX 78754. \\ (Email: sikard@usgs.gov)
}

\begin{abstract}
The Ellenburger-San Saba aquifer discharges springflow into the streambed of Hamilton Creek in Burnet County, central Texas. The aquifer is susceptible to contamination from surface-water reservoirs because of the presence of dissolution cavities that are hydraulically connected to the reservoirs in some locations. There is concern that preferential groundwater seepage from reservoirs into the aquifer in these locations might ultimately degrade the quality of the springwater that enters Hamilton Creek. To investigate preferential groundwater seepage patterns and hydraulic connectivity between surface-water reservoirs and the Ellenburger-San Saba aquifer, geophysical reconnaissance surveys were completed between July 2017 and January 2018 to map dissolution cavities and locate preferential groundwater flow paths within a specific region of the aquifer (Ikard and Pease, 2019). Two-dimensional electric resistivity tomography and self-potential profiling were utilized, and a simplified, three-dimensional finite-element model of the
\end{abstract}

field site was constructed to provide an interpretive aid. The self-potential data indicated the occurrence of preferential groundwater flow through a high-permeability conduit that was imaged by electric resistivity tomography but did not indicate the occurrence of groundwater flow through two fluid-filled dissolution cavities that were also imaged by electric resistivity tomography. Collectively, the surveying and modelling results demonstrate the efficacy of geoelectric methods for mapping the locations of dissolution cavities and preferential groundwater flow paths in the electrically resistive karst terrane of the Ellenburger-San Saba aquifer.

\section{Reference Cited}

Ikard, S., and Pease, E., 2019, Preferential groundwater seepage in karst terrane inferred from geoelectric measurements: Near Surface Geophysics, 2019, v. 17, p. 43-53. [Available at https://doi.org/10.1002/nsg.12023.] 


\title{
Cave Overburden Measurements Using Muons
}

\author{
By Thomas H. Prettyman, ${ }^{1}$ Glen E. Cushing, ${ }^{2}$ and Timothy N. Titus ${ }^{2}$
}

\author{
'Planetary Science Institute, 1700 East Fort Lowell, Suite 106, Tucson, AZ 85719. \\ ${ }^{2}$ U.S. Geological Survey, 2255 N. Gemini Dr., Flagstaff, AZ 86001. \\ (Email: prettyman@psi.edu)
}

\begin{abstract}
The application of atmospheric muons to measure the overburden column density of rock above a cave is described. The bulk density and microporosity of the cave ceiling can be determined from the muon measurements if the geometry of the cave is known. Temporal changes in the overburden column following precipitation are sensitive to the permeability of the rock, which controls water flow through the rock formation and into the cave. Results for a preliminary mapping study within a lava tube using a portable muon overburden gauge are presented.
\end{abstract}

\section{Introduction}

A compact, portable gauge for in situ measurements of the overburden (mass column) of cave ceilings was investigated. The gauge detects muons, subatomic charged particles produced by galactic cosmic ray interactions with the upper atmosphere. Muons arrive at the surface of the Earth in abundance (about 10,000 muons per square meter per second) and can travel large distances undeflected through rocks. Consequently, they have been used to determine subsurface depth and to image the interior of large structures (George, 1955; Alvarez and others, 1970; Tanaka, 2015). They may also find use in characterizing planetary caves (Prettyman and others, 2015). In this study, the attenuation of the vertical flux by cave ceiling materials was measured to determine the ceiling thickness in mass units of grams per square centimeter $\left(\mathrm{g} / \mathrm{cm}^{2}\right)$ or meters of standard rock (Lohmann and others, 1985) (fig. 1). If the geometric thickness of the ceiling is known, then the density and macroporosity of the rock can be determined. Data needed to constrain permeability and water saturation can be acquired by monitoring changes in the rock column in response to rainfall. Observed column variations along with rain gauge data can be fitted with models of groundwater flow through fractured media to determine permeability. Studies of permeability can be validated with a geotechnical survey of exposed portions of the cave ceiling such as at the entrance of the cave or in the interior. Percolation of meteoric water is a potential source of perennial and seasonal ice found in temperate caves. The overburden gauge can be used to support planetary analog studies of cave ice stability (PASCIS) as proposed by the U.S. Geological Survey and the Planetary Science Institute (Prettyman and others, 2020).

\section{Methods}

A ruggedized, battery-operated, low size, weight (about 3 kilograms), and power (SWaP) gauge that can be carried into a cave in a backpack and operated by a geologist was developed for this investigation (Prettyman and others, 2020). The gauge uses a plastic scintillator read out by a silicon photomultiplier to detect muons. An electronic collimation method is used to restrict the field of view of the gauge (fig. 1) and to separate muons from gamma rays produced by the decay of natural radioelements present in the surrounding rock. The measured attenuation of muons is converted to an overburden column using a calibration curve (Prettyman and others, 2020). The detector was sized to enable high throughput measurements (about 15 minutes per measurement location) to support cave mapping studies and monitoring overburden changes in response to rainfall.

\section{Results}

A preliminary mapping study was carried out in May 2019 in the Lava River Cave, a 1.2-kilometer-long lava tube in the Coconino National Forest near Flagstaff, AZ (fig. 2A). The lava tube quickly descends several tens of meters from the entrance to the lowest and coldest part (annual mean temperature of $2.8^{\circ} \mathrm{C}$ ) of the cave. Ice forms seasonally in this part of the cave, most likely from the condensation of water vapor; however, this emplacement mode has never been confirmed. After the rocky descent, the lava tube flattens out with a gradual increase in elevation for the remainder of the cave. The back of the cave has an average annual temperature of $7.2^{\circ} \mathrm{C}$. Because of the gradual rise in elevation, cold air is trapped closer to the entrance of the cave. The geometry of this cave, where the back is isolated from any cold-trapped air by being at a slightly higher elevation, provides a unique opportunity to validate thermal conduction as the dominant controlling factor for the back of the cave's microclimate and places constraints on the thermophysical properties of the overlying rock. 


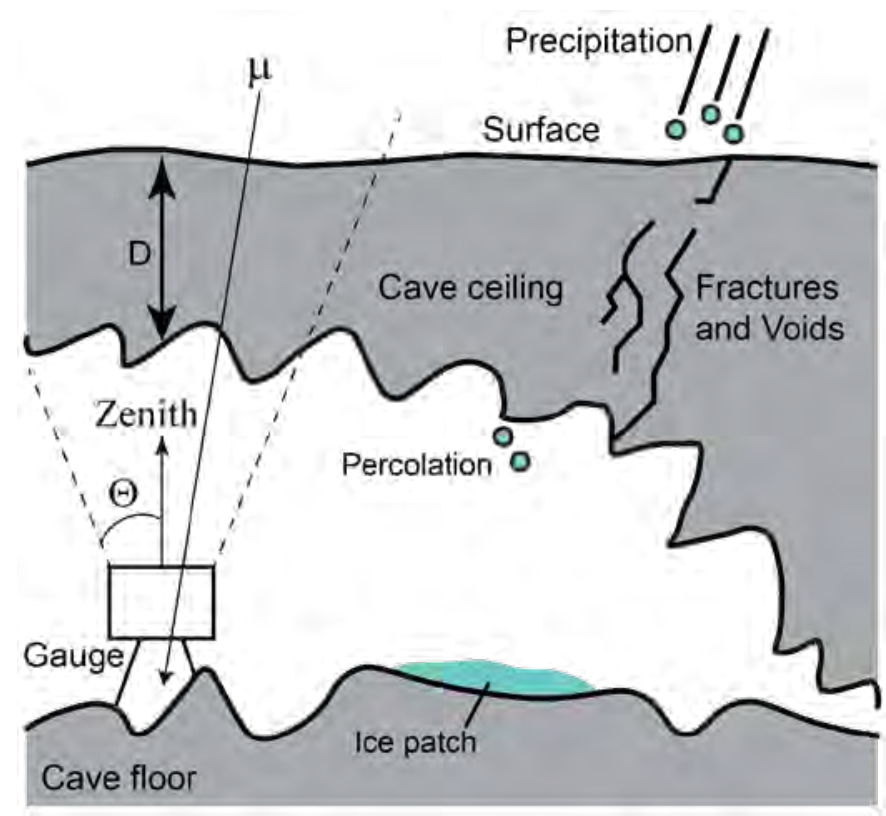

Figure 1. Diagram illustrating the use of a portable gauge for in situ measurements of the mass overburden above cave ceilings. A compact, portable gauge measures the downward flux of muons produced by galactic cosmic ray interactions in the upper atmosphere. The attenuation of muons $(\mu)$ by the cave ceiling is determined by comparing measurements made in the cave to measurements made on the surface. The measured attenuation is converted to ceiling mass overburden (D) using a calibration curve. $D$ is the average column $\left(\mathrm{g} / \mathrm{cm}^{2}\right.$ or meters of standard rock) within the field of view $(\Theta)$ of the gauge. Overburden can change, for example, as meteoric water flows through porous/ fractured rock. As such, muon overburden measurements provide constraints on percolation, which can contribute to the formation of perennial and seasonal ice found in temperate caves.

Overburden measurements were made at 12 measurement stations with 15-minute accumulation times (fig. 2B). The distance along the cave and geometric depth were estimated using a laser range finder and measurements of pressure. The uncertainty in these geometric measurements is large. As such, they are inadequate to determine the density of the cave ceiling; however, the geometric thicknesses determined from the measured overburden using the gauge and assuming standard rock $\left(2.65 \mathrm{~g} / \mathrm{cm}^{3}\right)$ for the density of the cave ceiling, were consistent with estimated depths. The entire length of the cave was measured on the last of several rainy days. The rain ended overnight, and the next day the measurements were repeated at selected stations. For some locations, the overburden column decreased, which is presumed to have resulted from draining of the rock formation following the rain event.

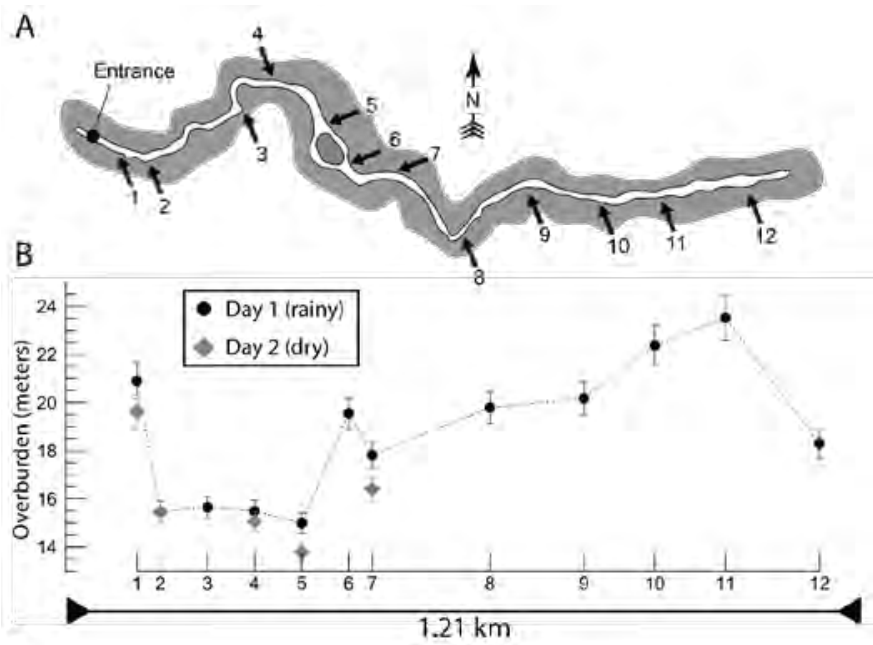

Figure 2. A, Diagram of Lava River Cave, a 1.21-kilometer (km)-long lava tube in Coconino National Forest, Flagstaff Ranger District, near Flagstaff, AZ. The numbered arrows indicate locations where 15-minute accumulations were made with the muon overburden gauge. B, The overburden, in meters, assuming the density of the cave ceiling is $2.65 \mathrm{~g} / \mathrm{cm}^{3}$ (standard rock) is shown for each of the measurement stations. The error bars indicate counting uncertainties. The first day of measurements (Day 1) occurred during rainy weather, which had lasted several days. Measurements were repeated at selected locations the following day after the rain stopped. Decreased overburden column for some locations may indicate draining of the rock formation.

\section{Conclusions and Future Work}

A low-SWaP gauge was developed and tested for rapid, in situ measurements of the mass overburden above terrestrial caves. Data acquired by the gauge provides constraints on the density and porosity of the rocks that make up the cave ceiling. In addition, monitoring changes in the overburden in response to rainfall constrains rock formation permeability and water saturation, parameters that are difficult to measure in the field. Additional work is required to verify that changes in the overburden column observed in the Lava River Cave are correlated with rainfall. In addition, a georeferenced lidar survey of the cave is needed to further validate the observations and to provide data needed to quantify physical properties of the cave roof. When geometric data are unavailable or inaccurate, muon overburden measurements may provide the most accurate estimates of roof thickness. Similar instrumentation may be feasible for planetary caves, and if so, measurements of muons could support studies of radiation shielding and structural stability. 


\section{Acknowledgments}

Work in the Lava River Cave was carried out with permission from the U.S. Forest Service, Flagstaff Ranger District. Development of the muon overburden gauge was partially supported by NASA programs, including Planetary Instrument Concepts for the Advancement of Solar System Observations (PICASSO Grant \#NNX16AK42G), the Solar System Exploration Research Virtual Institute Toolbox for Research and Exploration (TREX, Cooperative Agreement NNH16ZDA001N), and NASA Innovative Advanced Concepts (NIAC). Support was also provided by discretionary institutional funds from the Planetary Science Institute and the U.S. Geological Survey Astrogeology Science Center.

\section{References Cited}

Alvarez, L.W., Anderson, J.A., Bedwei, F.E., Burkhard, J., Fakhry, A., Girgis, A., Goneid, A., Hassan, F., Iverson, D., Lynch, G., Miligy, Z., Moussa, A.H., Sharkawi, M., and Yazolino, L., 1970, Search for hidden chambers in the pyramids: Science, v. 167, p. 832-839.
George, E.P., 1955, Cosmic rays measure overburden of tunnel: Commonwealth Engineer, p. 455-457.

Lohmann, W., Kopp, R., and Voss, R., 1985, Energy loss of muons in the energy range 1-10000 GeV: CERN Report 85-03, 29 p.

Prettyman, T.H., Titus, T.N., Boston, P.J., Koontz, S., and Miller, R.S., 2015, Mapping overburden and cave networks with muons [abs.]: 2nd International Planetary Caves Conference, https://www.hou.usra.edu/meetings/ 2ndcaves2015/pdf/9030.pdf.

Prettyman, T.H., Titus, T.N., Cushing, G.E., Okubo, C.H., Sankey, J.B., Williams, K.E., Caster, J., Boston, P.J., Schorghofer, N., and Spilde, M.N., 2020, Muon overburden gauge for planetary analog studies of cave ice stability [abs.]: 3rd International Planetary Caves Conference, https://www.hou.usra.edu/meetings/3rdcaves2020/pdf/ 1044.pdf.

Tanaka, H.K.M., 2015, Muographic mapping of the subsurface density structures in Miura, Boso, and Izu Peninsulas, Japan: Scientific Reports, DOI: 10.1038/srep08305. 


\title{
Using Deep Resistivity Imaging to Target Fault Structures for Water Supply, Arbuckle-Simpson Aquifer, Oklahoma
}

\author{
By Todd Halihan' ${ }^{1}$ and Madison Culver ${ }^{1}$ \\ ${ }^{1}$ Oklahoma State University, Boone Pickens School of Geology, 105 Noble Research Center, Stillwater, OK 74078. \\ (Email: todd.halihan@okstate.edu)
}

\begin{abstract}
Water supply for several municipalities in parts of southern Oklahoma is obtained from groundwater from springs and wells in the Arbuckle-Simpson aquifer. The purpose of the research conducted in this study is to site a reliable water supply well in the Arbuckle Group to supply a water district in a region of the aquifer with traditionally poor yields. Previous studies have shown that the area is a complex faulted dolomite with uncertainty in fault location and properties, and that the karstified faults and bedding planes of this carbonate aquifer are the best locations for high yield wells at depths greater than 30 meters (100 feet).
\end{abstract}

Work has proceeded at several sites to test electrical imaging to depths between 150 and 350 meters (500 and 1,150 feet). For the proposed well site, an 1,110-meter (3,610-foot)-long multi-electrode resistivity line was used to produce an electrical image with a depth of investigation of 220 meters (730 feet). Analysis of these data indicates that the faulting in the area is more complex than previously thought. Test drilling indicates the 220-meter (730-foot) drilling target for the aquifer can provide 450 gallons per minute in a region that typically produces only 10 gallons per minute. The logistical and interpretation issues for collecting multi-electrode resistivity data at this scale will also be discussed. 


\title{
Abstracts-Karst Geomicrobiology
}

\section{Harmful Algal Blooms in Karst Terrains}

\author{
By Tom D. Byl, ${ }^{1,2}$ Benjamin Miller, ${ }^{1}$ Rickard Toomey, ${ }^{3}$ and De'Etra Young ${ }^{2}$
}

${ }^{1}$ U.S. Geological Survey, 640 Grassmere Park, Suite 100, Nashville, TN 37211.

${ }^{2}$ Tennessee State University, College of Agriculture, 3500 John A Merritt Blvd, Nashville, TN 37209.

${ }^{3}$ Mammoth Cave National Park, Division of Science and Resource Management, P.O. Box 7, Mammoth Cave, KY 42259.

(Email: tdbyl@usgs.gov)

\section{Abstract}

Harmful algal blooms (HABs), often caused by cyanobacteria (blue-green algae), are increasingly a water-quality concern across the United States due to their production of cyanotoxins. Toxin-producing cyanobacteria were found in 74 percent of the 79 southeastern United States streams and rivers surveyed by the U.S. Geological Survey in 2015; cyanotoxins were found in about 35 percent of the 79 rivers. Middle and east Tennessee and Kentucky depend on surface-water resources for water supply and irrigation, and these resources are vulnerable to HABs. However, very little is known about the spatial and temporal occurrence of HABs in middle and east Tennessee. Microcystis, Oscillitoria, Leptolyngbya, Planktothrix, Nostoc, Dolichospermum, and Hapalosiphon are types of cyanobacteria that have continued to thrive in Tennessee and Kentucky and have adapted to grow near lights used for tours in the cave passages at Mammoth Cave National Park.
During preliminary cyanotoxin testing, 10 out of 11 cave sites with visible algal growth tested positive for microcystin (total concentration range was 0.154 to 2.59 micrograms per liter $[\mu \mathrm{g} / \mathrm{L}]$ and analyzed using Enzyme-Linked ImmunoSorbent Assays [ELISA]). No microcystins were detected at control sites in Mammoth Cave where algae were not visible. Another common terrestrial cyanobacterium, Nostoc commune, found growing along the surface of limestone gravel paths had microcystin concentrations ranging from 0.0 to $16.6 \mu \mathrm{g} / \mathrm{L}$. The difference in toxin concentrations between the cyanobacteria growing near the lights and the growth along the gravel paths may be due to differences in algal community structure, light intensity, subtle geochemical variances, moisture, or some other environmental factor. These preliminary findings raise interesting questions such as, what percent of the terrestrial cyanobacteria are capable of producing toxins, what toxins are they capable of producing, and what are the environmental signals that trigger the production of toxins in this environment? 


\title{
Lampenflora Pigment and Microcystin Toxin in Mammoth Cave National Park, Kentucky
}

\author{
By Brittaney Hogan, ${ }^{1}$ Rickard Toomey, ${ }^{2}$ De'Etra Young, ${ }^{1}$ and Thomas By|l,3
}

\author{
${ }^{1}$ Tennessee State University, College of Agriculture, 3500 John A Merritt Blvd, Nashville, TN 37209. \\ ${ }^{2}$ Mammoth Cave National Park, Division of Science and Resource Management, P.O. Box 7, Mammoth Cave, KY 42259. \\ ${ }^{3}$ U.S. Geological Survey, 640 Grassmere Park, Suite 100, Nashville, TN 37211. \\ (Email: tdbyl@usgs.gov)
}

\begin{abstract}
Algae have adapted to live in a variety of terrestrial environments, even in the cave passages at Mammoth Cave National Park. Cyanobacteria (blue-green algae) and chlorophyta (green algae) are the two main algae that grow close to the tour lights installed along the cave passages. These cave-adapted algal growths are called lampenflora. The lampenflora are considered a nuisance because they are not a natural cave flora and can detract from a natural cave experience. Additionally, it is unknown how the presence of lampenflora affects cave biota. Some cyanobacteria have been shown to produce cyanotoxins such as microcystin, which can present a danger to cave fauna and tourists.
\end{abstract}

The objective of this research was to develop quick, reliable tools that could be used to characterize the lampenflora and differentiate between cyanobacteria and chlorophyta. Lampenflora sites that represented communities of cyanobacteria and chlorophyta were characterized using a dual-channel fluorescence-based sensor (sensors for chlorophyll a and phycocyanin). The ratio of chlorophyll a to phycocyanin provided a quick method to evaluate if the algal community is dominated by cyanobacteria or chlorophyta. The intensity of the reading provided some indication of lampenflora coverage on the rock but maxed out when the cave wall was more than 60 -percent covered with lampenflora. Additional research will look at the correlation between cyanotoxin and pigment concentrations to determine if the chlorophyll a or phycocyanin is an indicator of toxin levels. 


\title{
Insights Into the Microbial Diversity of the Karstic Upper Floridan Aquifer
}

\author{
Brent C. Christner ${ }^{1}$ \\ ${ }^{1}$ University of Florida, Department of Microbiology and Cell Science, 1355 Museum Dr., Gainesville, FL 32611. \\ ${ }^{2}$ University of Florida, Department of Geological Sciences, 241 Williamson Hall, Gainesville, FL 32611. \\ (Email: abarrysosa@ufl.edu)
}

By Adrian Barry-Sosa, ${ }^{1}$ Madison K. Flint, ${ }^{2}$ Andrew Oberhelman, ${ }^{2}$ Justin C. Ellena, ${ }^{1}$ Jonathan B. Martin, ${ }^{2}$ and

\section{Abstract}

The Upper Floridan aquifer (UFA) is the top unit of the Floridan aquifer system, which is a hydrogeological formation underlying the Florida Peninsula, as well as parts of southern Georgia and Alabama. In Florida, the thickness of the UFA varies between 10 and 500 meters (Miller, 1986; Williams and Kuniansky, 2016). For most of its extension, it is a confined aquifer, but in northcentral Florida, the top confining unit has been removed by erosion and is a location where several springs discharge from the UFA. Twelve springs from locations within the unconfined portion of the UFA, which were classified in three main groups according to their residence times and geochemical characteristics, were studied. The first group consisted of five of the Ichetucknee springs that do not directly interact with surficial waters. The second group of five springs is in proximity to rivers that experience reversals (for example, intrusion of river water into the spring during flooding), with a frequency varying from a few times a year to once every few years. Finally, two locations were sampled in the Santa Fe River system, which is a location where the Santa Fe River enters a sink and flows underground for approximately 6 kilometers, where it subsequently mixes with UFA water discharged from the matrix.

There are no significant differences in temperature, $\mathrm{pH}$, specific conductivity, oxidation-reduction potential, or turbidity in water discharging from the Ichetucknee Springs group and the reversing springs group at base flow, but there are highly significant differences in oxygen concentration (statistical p-value less than $0.001[\mathrm{p}<0.001]$ ). In contrast, all of these geochemical parameters have high temporal variability in the Santa Fe River system attributed to the heavy influence of surficial waters. Nitrous oxide has been measured in concentrations well above atmospheric in all sampled springs (Flint and others, 2021) and evidence has been documented of methane being produced in deeper parts of the UFA. Production and consumption of these greenhouse gases are likely controlled by microbial pathways dependent on the concentrations of reactive nitrogen species, as well as the lability of dissolved organic matter.
Microbiological sampling of springwaters has revealed significantly lower cell concentrations $(p<0.001)$ in springs that discharge only UFA water compared with those that interact more frequently with surficial waters. Measurement of adenosine triphosphate (ATP) as a proxy for viable biomass indicates that there are no significant differences in ATP concentration per cell among the springs except for the Devil's Eye Spring, that is part of the Ichetucknee Springs group $(p<0.001)$. This spring also has the lowest dissolved oxygen concentration in this group $(0.25$ plus or minus 0.02 milligram per liter), and the water is estimated to have an apparent age of around 40 years based on ${ }^{3} \mathrm{H} / 3 \mathrm{He}, \mathrm{CFC}-11$, CFC-12, and CFC-113 tracers, which is substantially older than that of other springs in the same group (Martin and others, 2016).

Amplification and sequencing of $16 \mathrm{~S}$ ribosomal RNA genes (16S rRNA) revealed that the most abundant phylum in the springs is Proteobacteria, with an average abundance of 45 percent across all samples, followed by Bacteroidetes with 10 percent. The bacterial phylum Patescibacteria and the archaeal DPANN (named after the first five phyla defined in it: Diapherotrites, Parvarchaeota, Aenigmarchaeota, Nanoarchaeota, and Nanohaloarchaeota) are the third and seventh most abundant groups, representing 7.2 and 2.6 percent, respectively. Devil's Eye Spring had one of the highest abundances of phyla belonging to the DPANN and Parcubacteria, with a combined abundance in the 0.1 micrometer filter fraction of approximately 70 percent. The high abundances of these groups in this environment opens the possibility for focused studies of these poorly known phyla to understand fundamentals about their biology and processes. We have found that their abundances negatively correlate with the oxygen concentration (correlation coefficient of $-0.66, p=0.044$ for Patescibacteria and a correlation coefficient of $-0.81, \mathrm{p}=0.008$ for DPANN), which is consistent with metabolic predictions from metagenomic studies that imply they are anaerobic microbes that use fermentation for bioenergetics (Castelle and others, 2017; Liu and others, 2018; Beam and others, 2020). 
In spite of the UFA's key role as a freshwater source for a large part of Florida, the microbial processes at play here as well as in other subsurface karstic environments are not very well characterized. The abundance of poorly studied microbial groups opens the possibility for describing new lifeforms that have expanded the tree of life, and to better understand the role UFA microbial communities have in shaping the water geochemistry.

\section{References Cited}

Beam, J.P., Becraft, E.D., Brown, J.M., Schulz, F., Jarett, J.K., Bezuidt, O., Poulton, N.J., Clark, K., Dunfield, P.F., Ravin, N.V., Spear, J.R., Hedlund, B.P., Kormas, K.A., Sievert, S.M., Elshahed, M.S., Barton, H.A., Stott, M.B., Eisen, J.A., Moser, D.P., Onstott, T.C., Woyke, T., and Stepanauskas, R., 2020, Ancestral absence of electron transport chains in Patescibacteria and DPANN: Frontiers in Microbiology, v. 11, p. 1-16, https://doi.org/10.3389/fmicb.2020.01848.

Castelle, C.J., Brown, C.T., Thomas, B.C., Williams, K.H., and Banfield, J.F., 2017, Unusual respiratory capacity and nitrogen metabolism in a Parcubacterium (OD1) of the Candidate Phyla Radiation: Scientific Reports, v. 7, p. 1-12, https://www.nature.com/articles/srep40101.
Flint, M.K., Martin, J.B., Summerall, T.I., Barry-Sosa, A., and Christner, B.C., 2021, Nitrous oxide processing in carbonate karst aquifers: Journal of Hydrology, v. 594, 13 p., https://www.sciencedirect.com/science/article/abs/pii/ S0022169420313974.

Liu, X., Li, M., Castelle, C.J., Probst, A.J., Zhou, Z., Pan, J., Liu, Y., Banfield, J.F., and Gu, J.D., 2018, Insights into the ecology, evolution, and metabolism of the widespread Woesearchaeotal lineages: Microbiome, v. 6, 16 p., https://microbiomejournal.biomedcentral.com/articles/ 10.1186/s40168-018-0488-2.

Martin, J.B., Kurz, M.J., and Khadka, M.B., 2016, Climate control of decadal-scale increases in apparent ages of eogenetic karst spring water: Journal of Hydrology, v. 540, p. $988-1001$, https://www.sciencedirect.com/science/article/ abs/pii/S0022169416304401.

Miller, J.A., 1986, Hydrogeologic framework of the Floridan aquifer system in Florida and in parts of Georgia, Alabama, and South Carolina: U.S. Geological Survey Professional Paper 1403-B, 91 p., https://pubs.er.usgs.gov/publication/pp1403B.

Williams, L.J., and Kuniansky, E.L., 2016, Revised hydrogeologic framework of the Floridan aquifer system in Florida and parts of Georgia, Alabama, and South Carolina (ver. 1.1, March 2016): U.S. Geological Survey Professional Paper 1807, 140 p., 23 pls., http://dx.doi.org/10.3133/pp1807. 


\title{
Influence of the Cumberland River on Groundwater Flow Direction in a Fuel-Contaminated Aquifer in Nashville, Tennessee
}

\author{
By Darrius Lawson, ${ }^{1}$ Chris Vanags, ${ }^{2}$ De'Etra Young, ${ }^{1}$ Jessica Oster, ${ }^{2}$ and Tom Byl1,3 \\ ${ }^{1}$ Tennessee State University, College of Agriculture, 3500 John A Merritt Blvd, Nashville, TN 37209. \\ ${ }^{2}$ Vanderbilt University, Earth and Environmental Science, 5726 Stevenson Center, Nashville, TN 37240. \\ ${ }^{3}$ U.S. Geological Survey, 640 Grassmere Park, Suite 100, Nashville, TN 37211. \\ (Email: tdbyl@usgs.gov)
}

\begin{abstract}
The Tennessee State University research farm in Nashville, Tennessee, is located along the Cumberland River and has nine 250-foot-deep wells that can be used to monitor groundwater levels and quality. The wells have 6-inch steel casings to the top of bedrock (20-40 feet below land surface), and the lower part of the wells are open boreholes in limestone bedrock. The upper limestone is the Hermitage Formation which extends approximately 100 feet below land surface. Below the Hermitage Formation is the Carters Limestone. The research well located adjacent to the northern property line is contaminated with trace concentrations of benzene, ethyl benzene, and extractable petroleum hydrocarbons. Several potential sources of fuel contaminants occur adjacent to the site, making it important to understand groundwater flow direction to identify the source of the contaminants. Another unique feature of the water from the contaminated well is the high concentration of dissolved iron (greater than 5 milligrams per liter of ferrous iron). High levels of dissolved iron can be toxic to groundwater bacteria, which raised the concern that there may not be many indigenous bacteria capable of biodegrading fuel compounds.
\end{abstract}

The objectives of this study were to determine groundwater flow direction and if there were viable bacteria capable of biodegrading hydrocarbon compounds. To accomplish the first objective, groundwater levels were measured every 15 minutes in three research wells using water-level transducers. The water levels were confirmed with electrical tape measurements every 2 to 4 weeks in 2018-2019. The U.S. Geological Survey Cumberland River gage (USGS 03431514) located a quarter mile upstream of the farm provided river water-surface elevation for the same time period. The location and water elevations for the three wells and the Cumberland River were entered into the Environmental Protection Agency Groundwater Flow Model 3PE to triangulate the groundwater flow direction. The modeled groundwater hydraulic gradient fluctuated approximately 90 degrees in response to changing river and groundwater elevations. In addition to calculating flow direction, actively growing bacteria were measured using Biological Activity Reaction Test (BART) assays. Denitrifying iron-related and sulfur-related bacteria were present at 10,000 or more bacteria per milliliter in the contaminated well during three sampling events. Previous studies in contaminated karst aquifers found these bacteria types were capable of biodegrading petroleum compounds, but the rates varied depending upon the terminal electron acceptors present in the aquifer. 


\title{
Abstracts-Karst Aquifer Systems Karst Springs of Northern Arkansas
}

\author{
By Van Brahana ${ }^{1}$ and John Svendsen²
}

\author{
${ }^{1}$ Emeritus, U.S. Geological Survey. \\ ${ }^{1}$ Emeritus, University of Arkansas, 222 Gearhart Hall, Department of Geosciences, Fayetteville, AR 72701. \\ ${ }^{2}$ University of Arkansas at Little Rock, Department of Geology, Little Rock, AR 72204. \\ (Email: brahana@uark.edu)
}

\begin{abstract}
Arkansas has many thousands of springs, but unlike most of our surrounding sister states, has no comprehensive single publication that synthesizes their science, history, beauty, or attributes. Such publications aid in educating a non-technical audience about how springs function and how they can be protected. As urban, rural, and agricultural development expands in the state, a strong need to minimize the environmental impact of human activity on springs is becoming apparent, particularly for springs that occur in karst terranes. The Ozark Plateaus in northern Arkansas is a karst landscape, with widely varying geology that is responsible for distinctly different karst features and hydrology. Some parts of the Ozarks in Arkansas are renowned as easily visualized, well-developed karst, but most areas are mantled in regolith and not recognized by most of our citizens as having rapid flow and minimally attenuated groundwater quality. This presentation introduces attributes of selected karst springs and provides specifics about the human interface with these features, as well as selected details of their hydrogeology. The
\end{abstract}

human aspects include the role springs played in the settlement of the state, serving as sacred places, sourcing medical applications of mineral-water therapies, being vacation destinations and spas, serving as the dominant aspect of parks, and in conveying history through fascinating case studies. The hydrogeologic aspects include data showing natural variations in discharge, selected water-quality attributes and changes brought about by humans, and the recognition of their unique ecosystems and occurrence of fauna. Diagrams and photos supplement the descriptions and illustrate how karst spring systems work, providing insight into the fragile nature and the potential for contamination that is present in many of these typically unseen underground flow systems.

This presentation is part of a larger statewide spring project, "Arkansas - Land of a Thousand Springs." Utilizing a full-color, coffee-table-book format, this book seeks to inspire conversation, thought, insight, and ultimately, action. 


\title{
Evaluation of Bubbling Springs in the Arbuckle Formation, Southern Oklahoma
}

\author{
By Todd Halihan' ${ }^{1}$ and Robert Agnew²
}

${ }^{1}$ Oklahoma State University, Boone Pickens School of Geology, 105 Noble Research Center, Stillwater, OK 74078.

${ }^{2}$ Oklahoma State University, Division of Engineering Technology, 545 Engineering North, Stillwater, OK 74078.

(Email: todd.halihan@okstate.edu)

\begin{abstract}
Numerous karst groundwater springs bubble, yet the flow and transport of gases are not well understood in hydrogeology. An understanding of the processes by which gases enter, migrate, and are liberated from groundwater is required. Through analysis of existing published literature, seven facies of groundwater bubbles were developed to provide a framework for research in these specific categories of gas transport. Furthermore, a quantitative conceptual model of gas migration in groundwater allows an understanding of which informative aquifer signals are present in gas data and which information signals are masked or diminished by phase changes. To better understand multiphase bubbling springs, an instrument was subsequently designed and deployed over a spring discharge in southern Oklahoma that measured the
\end{abstract}

total gas flux, ebullative and diffusive. Discharge from the spring was measured to produce a hydropneumograph of gas and water mass flux over time, and water and gas samples were collected for compositional analysis. By combining the compositional data of exsolved and dissolved gas with the mass flow rates from the hydropneumograph, estimation of the quantity of light noble gases is radically changed (plus 60 percent for helium, plus 45 percent for neon). These changes in light noble gas quantities can affect the calculation of recharge temperature by 4 to 25 percent (depending on the model selected). The developed framework and these improvements in the understanding of bubbling karst springs provide an additional avenue for researchers to explore and quantify aquifer dynamics that are largely ignored in the extant literature. 


\title{
Abstracts-Simulation of Karst Aquifers \\ Recalibration at Sinking Pond, Tennessee-Implications of Climate Extremes for Understanding Hydrologic Controls on Karst Ecosystems
}

\author{
By Jennifer Cartwright ${ }^{1}$ and William Wolfe ${ }^{2}$ \\ ${ }^{1}$ U.S. Geological Survey, 640 Grassmere Park, Nashville, TN 37211. \\ ${ }^{2}$ Emeritus, U.S. Geological Survey. \\ (Email: jmcart@usgs.gov)
}

\begin{abstract}
Karst depression wetlands throughout the eastern United States are important to regional and global biodiversity but may be threatened by hydrologic shifts under climate change. For example, increased ponding duration since 1970 in Sinking Pond - a 35-acre seasonally flooded karst depression wetland on the Highland Rim of Tennessee - has been implicated in recruitment failure of overcup oak (Quercus lyrata). Hydrologic models based on rainfall and temperature records from 1854 through 2002 successfully simulated observed inundation patterns in Sinking Pond and showed that prolonged inundation (more than 200 days per year) was considerably more common after 1970 than before. However,
\end{abstract}

model calibration and validation datasets did not include extreme climatic events such as droughts. A subsequent severe drought in 2007 and 2008 provided an opportunity to recalibrate the Sinking Pond hydrologic model to better represent the drivers of pond inundation across a wider range of climate conditions. Although recalibration of published hydrologic models is relatively rare, this study demonstrates its importance for ecohydrologic studies, as climatic extremes (droughts and intense storms) may become more common under climate change than they were in historical records. This study has potential relevance for a variety of karst-dependent ecosystems in which ecological shifts may be driven by changing hydrologic conditions. 


\title{
Simulating Groundwater Flow in Karst Aquifers With Distributed Parameter Models-A Comparison of Porous-Equivalent Media and Hybrid Flow Approaches
}

\author{
By Eve L. Kuniansky ${ }^{1}$ \\ ${ }^{1}$ U.S. Geological Survey, 1700 Corporate Drive, Suite 500, Norcross, GA 30093. \\ (Email: elkunian@usgs.gov)
}

\section{Abstract}

Understanding karst aquifers for purposes of their management and protection, poses unique challenges. Karst aquifers are characterized by groundwater flow through conduits (tertiary porosity), and (or) rock layers with interconnected large pores (secondary porosity with interconnected macropores greater than $0.5 \mathrm{inch}$ ), which occur in carbonate rock usually from biologic activities of burrowing animals, such as shrimp or clams), and (or) through intergranular pores (primary or matrix porosity, pores generally much less than 0.5 inch). Since the late 1960 s, advances have been made in the development of numerical computer codes and the use of mathematical model applications toward the understanding of dual (primary [matrix] and tertiary [fractures and conduits]) porosity groundwater flow processes, as well as characterization and management of karst aquifers. The computer code MODFLOW Conduit Flow Process allows for simulation of all three types of porosity (Shoemaker and others, 2008).

The Floridan aquifer system in Florida and parts of Alabama, Georgia, and South Carolina, consists of a thick sequence of predominantly carbonate rocks. Karst features are present over much of its area, especially in Florida where more than 30 first-magnitude (average flow of more than 100 cubic feet per second) springs occur, numerous sinkholes and submerged conduits have been mapped, and numerous circular lakes within sinkhole depressions are present. Different types of mathematical models have been applied to simulations of the Floridan aquifer system. Most of these models are distributed parameter models based on the assumption that, like a sponge, water flows through connected pores within the aquifer system and can be simulated with the same mathematical methods applied to flow through sand and gravel aquifers; these models are usually referred to as porous-equivalent media models. The partial differential equation solved for groundwater flow is the potential flow equation of fluid mechanics, which is used when flow is dominated by potential energy and has been applied to many fluid problems in which kinetic energy terms are dropped from the differential equation solved. In many groundwater model codes (basic MODFLOW; Harbaugh, 2005), it is assumed that the water has a constant temperature and density and that flow is laminar, such that kinetic energy has minimal impact on flow. Some models have been developed that incorporate the submerged conduits as a one-dimensional pipe network within the aquifer rather than as discrete, extremely transmissive features in a porous-equivalent medium (Hill and others, 2010; Gallegos and others, 2013). These submerged conduit models are usually referred to as hybrid models and can include the capability to simulate both laminar and turbulent flow in the one-dimensional pipe network.

Comparisons of the application of a porous-equivalent media model with and without turbulence (MODFLOWConduit Flow Process mode 2 and basic MODFLOW, respectively) and a hybrid (MODFLOW-Conduit Flow Process mode 1) model to the Woodville Karst Plain near Tallahassee, Florida, were made and fully discussed in Davis and others (2010), Gallegos and others (2013), and Kuniansky (2016a), which is the source of this abstract and figures (slightly modified for this proceedings). Figure 1 shows the location of cells with mapped conduits for the hybrid model and cells with large hydraulic conductivity for the two porousequivalent media models. The simulations indicated that for annual, monthly, or seasonal average hydrologic conditions, all modeling approaches met calibration criteria. Thus, the increased effort required, such as the collection of data on conduit locations to develop a hybrid model and its increased computational burden, is not necessary for simulation of average hydrologic conditions because non-laminar flow effects on simulated head and spring discharge are minimal. However, simulation of a large storm event in the Woodville Karst Plain with daily stress periods indicated that turbulence is important for matching daily springflow hydrographs with either a porous-equivalent media model or the hybrid model. Thus, if matching streamflow hydrographs over a storm event is required, the simulation of non-laminar flow and the location of conduits is required. 


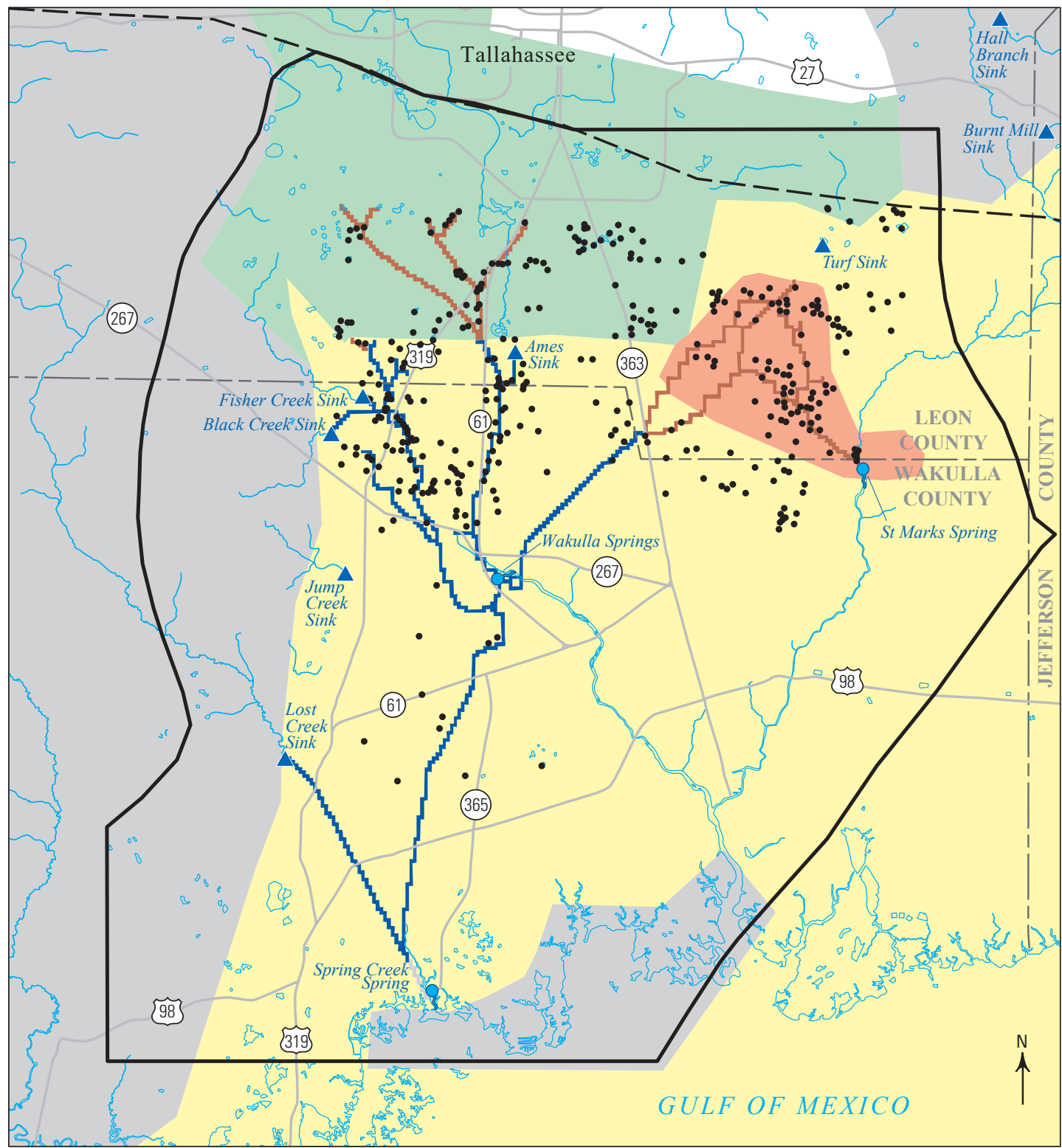

Base modified from U.S. Geological Survey digital data, 1:24,000 Albers Equal-Area Conic projection, North American Datum of 1983

Standard parallels $29^{\circ} 30^{\prime}$ and $45^{\circ} 30^{\prime}$, central meridian $-83^{\circ} 00^{\prime}$

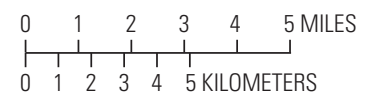

Modified from Davis and others, 2010, figure 27

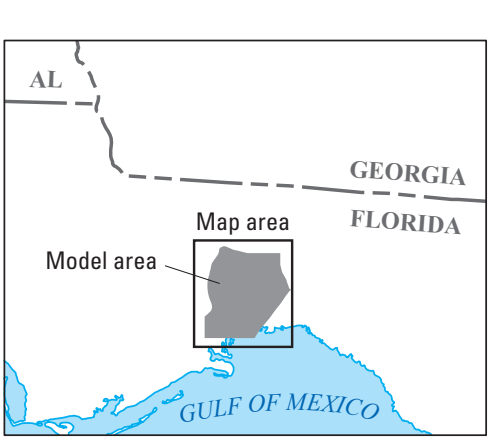

\section{EXPLANATION}

Simulated horizontal hydraulic conductivity in model layer 2 . in feet per day

10 to 100

101 to 1,000

1,001 to 10,000

10,001 to 100,000

100,001 to $1,000,000$

$1,000,001$ to $5,000,000$

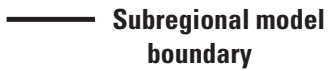

- - Cody Scarp

- Sinkhole

A Sink-With creek inflow

- Spring-Tail points in direction of flow

Figure 1. Simulated hydraulic conductivity in model layer 2 with large hydraulic conductivity located at submerged conduits for approaches B and C on figure 2, Woodville Karst Plain, Florida. 
Figure 2 shows steady-state potentiometric maps for average conditions comparing the hybrid model to two porous-equivalent media models - a hypothetical with no large hydraulic conductivity cells at the conduit locations and one with. This comparison indicates that for the Woodville Karst Plain the porous-equivalent media model can duplicate the hybrid model potentiometric map during average flow conditions with high hydraulic conductivity cells in the porous-equivalent media model at conduit locations.

The main challenge in application of the methods and approaches for developing hybrid models relates to the difficulty of mapping conduit networks or having high-quality datasets to calibrate these models. Additionally, hybrid models or porous-equivalent media models with large hydraulic conductivity contrasts at conduit locations have long simulation times (tend to create ill-conditioned models with slow convergence), which can preclude the use of parameter estimation for calibration. Simulation of contaminant transport that does not account for preferential flow through conduits or extremely permeable zones in any approach is ill-advised. Simulation results in other karst aquifers or other parts of the Floridan aquifer system may differ from the comparison presented. All model datasets are available from Kuniansky (2016b) for those that wish to experiment with any of these site models.

\section{References Cited}

Davis, J.H., Katz, B.G., and Griffin, D.W., 2010, Nitrate-N movement in groundwater from the land application of treated municipal wastewater and other sources in the Wakulla Springs springshed, Leon and Wakulla Counties, Florida, 1966-2018: U.S. Geological Survey Scientific Investigations Report 2010-5099, 90 p. [Also available at https://pubs.usgs.gov/sir/2010/5099/pdf/sir2010-5099_ davis_revised_3-2-2011.pdf.]
Gallegos, J.J., Hu, B.X., and Davis, Hal, 2013, Simulating flow in karst aquifers at laboratory and sub-regional scales using MODFLOW-CFP: Hydrogeology Journal, v. 21, no. 8, p. 1749-1760.

Harbaugh, A.W., 2005, MODFLOW-2005, the U.S. Geological Survey modular ground-water modelthe Ground-Water Flow Process: U.S. Geological Survey Techniques and Methods, book 6, chap. A16. [Also available at https://pubs.usgs.gov/tm/2005/tm6A16/.]

Hill, M.E., Stewart, M.T., and Martin, A., 2010, Evaluation of the MODFLOW-2005 Conduit Flow Process: Ground Water, v. 48, p. 549-559.

Kuniansky, E.L., 2016a, Simulating groundwater flow in karst aquifers with distributed parameter modelsComparison of porous-equivalent media and hybrid flow approaches: U.S. Geological Survey Scientific Investigations Report 2016-5116, 14 p. [Also available at https://doi.org/10.3133/sir20165116.]

Kuniansky, E.L., 2016b, MODFLOW and MODFLOW Conduit Flow Process data sets for simulation experiments of the Woodville Karst Plain, near Tallahassee, Florida with three different approaches and different stress periods: U.S. Geological Survey data release, http://dx.doi.org/10.5066/F7PK0D87.

Shoemaker, W.B., Kuniansky, E.L., Birk, S., Bauer, S., and Swain, E.D., 2008, Documentation of a Conduit Flow Process (CFP) for MODFLOW-2005: U.S. Geological Survey Techniques and Methods, book 6, chap. A24, 50 p. [Also available at https://pubs.usgs.gov/tm/tm6a24/pdf/tm6-A24.pdf.] 
A. Porous-equivalent media model No high conductivity $(K)$ cells at conduits

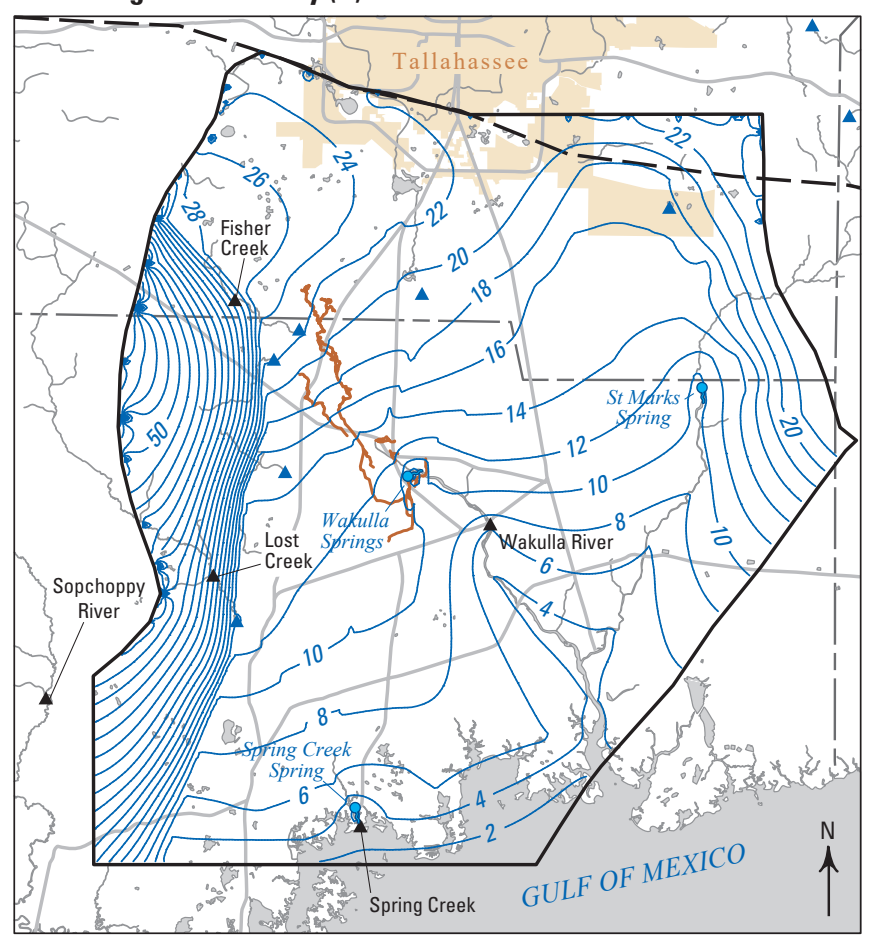

C. Hybrid model with 1-dimensional pipes linked to porous-equivalent media model

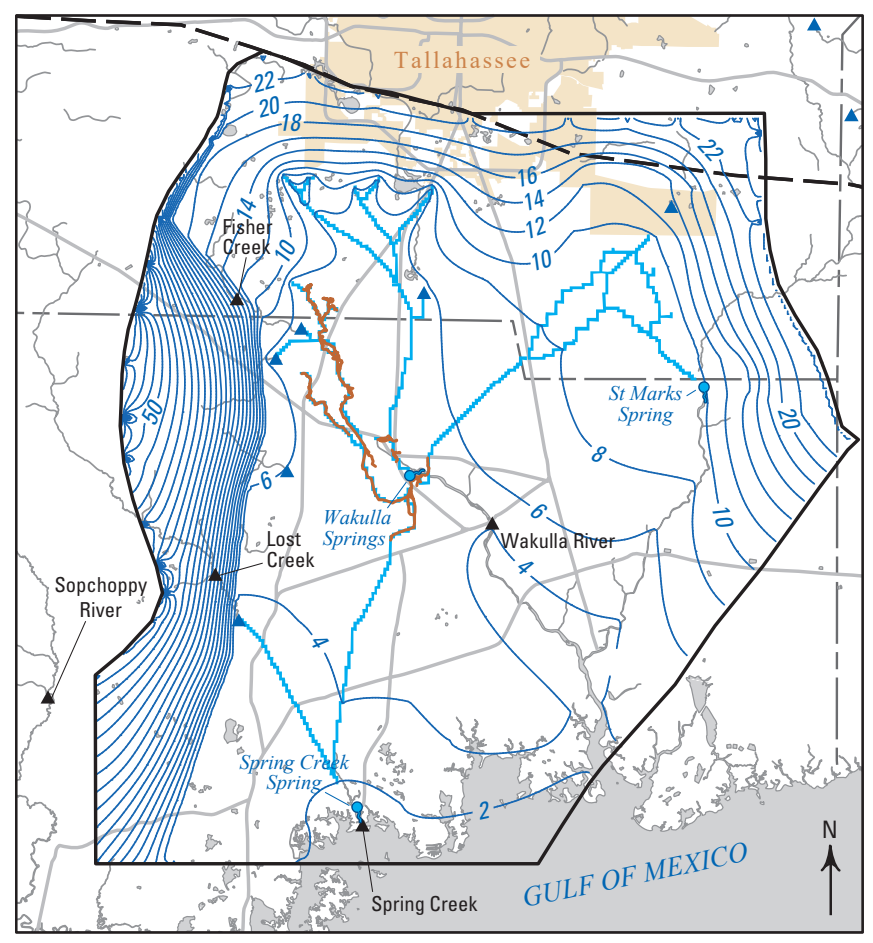

Modified from Kuniansky, 2016a
B. Porous-equivalent media model High $K$ cells at conduits

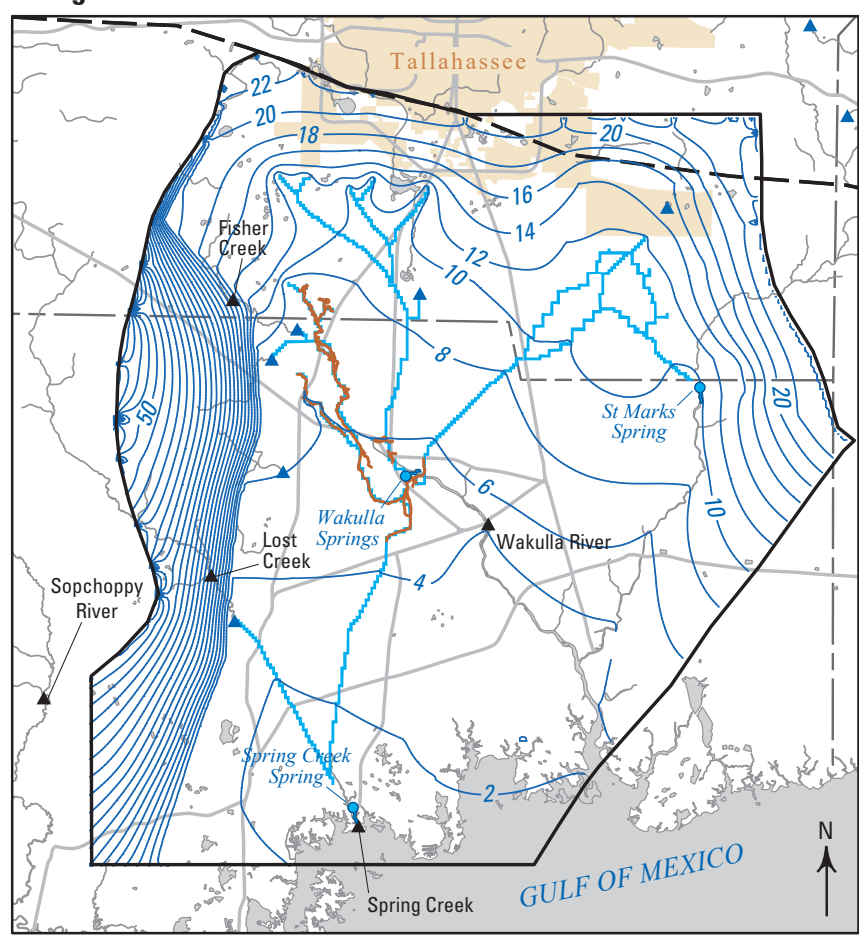

Base modified from U.S. Geological Survey 1:24,000-scale digital data

Albers Equal-Area Conic projection North American Datum of 1983

$\begin{array}{lllllll}0 & 1 & 2 & 3 & 4 & 5 \text { MILES }\end{array}$

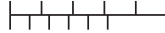
0122345 KILOMETERS

\section{EXPLANATION}

Subregional model boundary

Cody Scarp

Mapped submerged cave

- 2- Simulated potentiometric contour of model layer 2-Shows altitude at which water would have stood in tightly cased wells. Contour interval 2 feet. Datum is National Geodetic Vertical Datum of 1929

- Model cell with simulated conduit (maps $B$ and $C$ )

- Gaging station

- Sink-With creek inflow

- Spring-Tail points in direction of flow

Figure 2. Steady-state post-development simulated potentiometric maps of model layer 2 in the Woodville Karst Plain, Florida. $A$, hypothetical, uncalibrated single-continuum porous-equivalent media model with no high hydraulic conductivity (K) cells in conduits (modified with background $\mathrm{K}$ values used in cells with conduits), $B$, calibrated single-continuum porous-equivalent media model (high $\mathrm{K}$ cells where there are conduits) generated from model archive of Davis and others (2010), and $C$, calibrated hybrid model generated from model archive of Gallegos and others (2013). 


\title{
Karst Interest Group Field Trip Guide to the Cumberland Plateau of Tennessee
}

\author{
By Ben Miller ${ }^{1}$ and Brian Ham² \\ ${ }^{1}$ U.S. Geological Survey, 640 Grassmere Park, Suite 100, Nashville, TN 37211. \\ ${ }^{2}$ Tennessee Department of Environment and Conservation, 312 Rosa L. Parks Ave., Nashville, TN 37243. \\ (Email: bvmiller@usgs.gov)
}

\section{Introduction}

This field trip will focus on the hydrology and geology of the northern Cumberland Plateau of Tennessee (fig. 1). The karst of the Cumberland Plateau physiographic province is extensive, unique, and exhibits some of the greatest caves in the eastern United States. Field trip stops will focus on the stratigraphy of the Plateau and will visit some of the more famous recharge features, discharge features, and karst windows to provide context, scale, and give the participants an idea of the character of several major karst systems in Tennessee. There are five planned stops; however, the fifth stop may not be visited if we spend too much time at the first four stops. Please note, within the field trip guide are descriptions of numerous caves that are located on state-owned lands or may be privately owned. The locations of these caves are not shown on maps to protect sensitive cave resources and to respect landowners. Permission and (or) permits must be obtained for access to any of the caves described within this field trip guide.

\section{Stratigraphy}

The generalized stratigraphic sequence encountered along the field trip will consist of geologic units ranging from Mississippian to Pennsylvanian in age (fig. 2), and the following descriptions are referenced from the Grassy Cove geologic quadrangle map published by Milici (1965). The top of the stratigraphic sequence includes a series of sandstones and shales that are part of the Crab Orchard Mountain Group. Individual sandstone and shale units of this group in the Grassy Cove region include the Vandever Formation, Newton Sandstone, and Whitwell Shale (fig. 2). The lower units of this group (Sewanee Conglomerate) and the underlying Gizzard Group represent the uppermost unit encountered at other stops along the field trip (Bee Rock). The Sewanee Conglomerate is a yellowish-gray to yellowish-brown sandstone often exhibiting a crossbedded structure and containing quartz pebbles. Moving downward, the upper formation of the Gizzard Group is the Signal Point Shale, a light- to dark-gray silty shale ranging in thickness from 0 to 23 meters $(\mathrm{m})$ ( 0 to 75 feet [ $\mathrm{ft}]$ ), which is interbedded with yellowish-gray fine-grained sandstones and includes the Wilder coal seam near the top of the formation. Below the Signal Point Shale is the Warren Point Sandstone, the lowest formation in the sequence of the Pennsylvanian series in this area. The Warren Point Sandstone ranges in thickness from 0 to $15 \mathrm{~m}(0$ to $49 \mathrm{ft})$ and is a yellowish- to brownish-gray fine-grained sandstone, which exhibits crossbedding in some locations. The Pennington Formation underlies the Warren Point Sandstone and is the uppermost unit in the Mississippian sequence. The Pennington Formation consists of interbedded shale, sandstone, and limestone. The Pennington Formation has been studied recently in more depth by Hali Steinmann (Western Kentucky University) as part of her Master's thesis, which documents the controls on speleogenesis and provides insight into the lithologic and hydrologic conditions within the formation (Steinmann, 2018). Beneath the Pennington Formation lies the Bangor Limestone, a medium- to darkgray limestone that contains abundant fossil fragments and is oolitic in places. The Hartselle Formation, a grayish-orange to yellowish-brown sandstone, underlies the Bangor Limestone and is a major confining layer in the region. Where the Hartselle has been breached by erosion, many pit caves form along the contact between the Hartselle and the underlying Monteagle Limestone. The Monteagle Limestone is a medium-gray, thick-bedded limestone, and is one of the more prominent limestones that contain many of the classic deep pits and large caves along the Cumberland Plateau. The St. Louis Limestone underlies the Monteagle Limestone and is typically characterized by an abundance of chert that can influence local karst groundwater movement by perching water on the chert beds. Finally, the base of the stratigraphic section that will be seen on the trip is the Warsaw Limestone and the Fort Payne Formation. The Warsaw Limestone is a brownish-gray crystalline limestone that commonly is crossbedded. The Fort Payne Formation consists of limestones and dolomites, which are highly siliceous, varying from medium- to thick-bedded, and weathers to irregular beds of fossiliferous chert. 


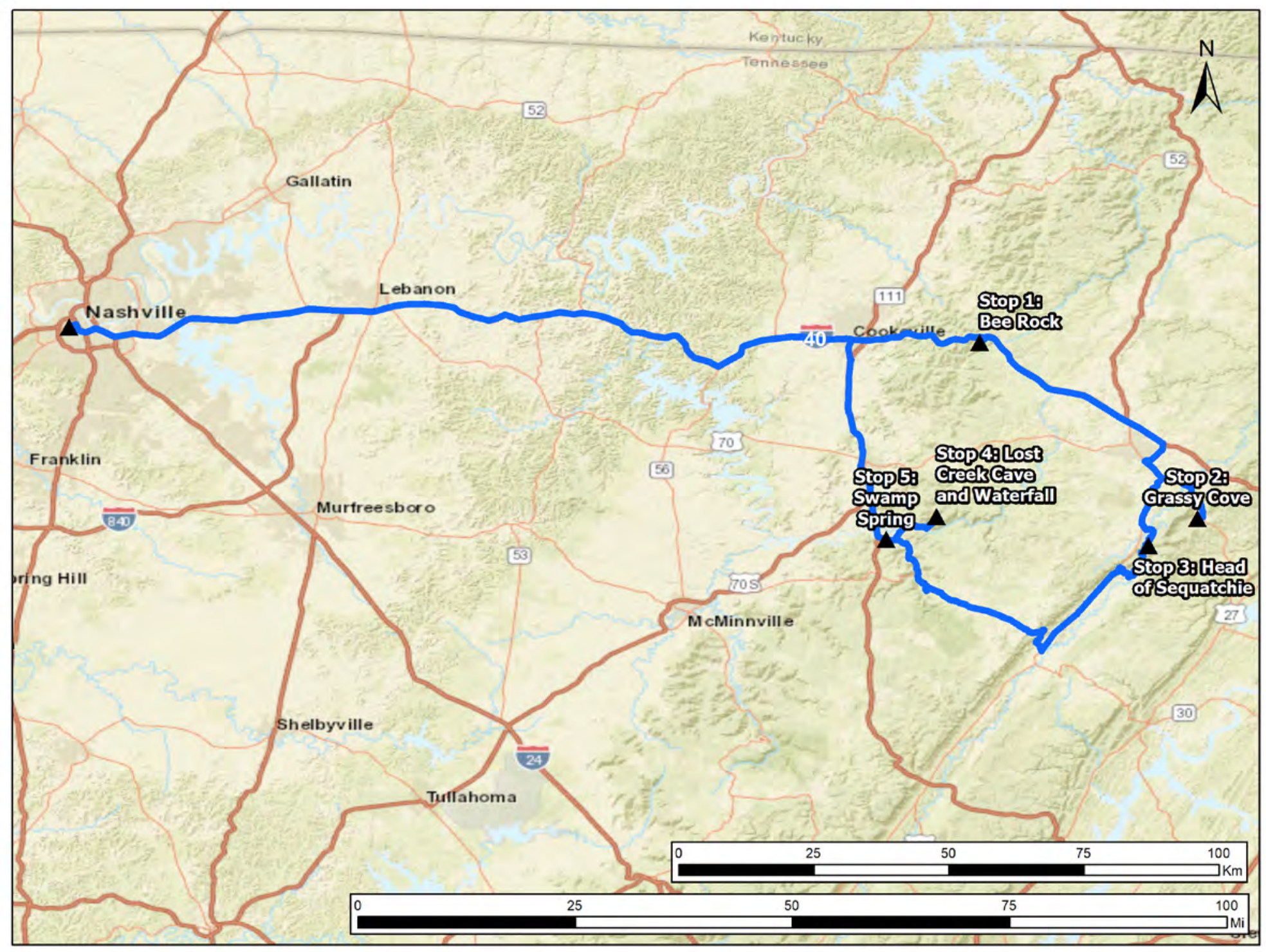

Figure 1. Route overview and five stop locations for the Karst Interest Group field trip to the Cumberland Plateau, Tennessee. Base map from ESRI "Terrain with labels," accessed February 6, 2020, at https://www.arc gis.com/home/item.html?id=fe44cf9a739848939988addfeba473e4. 


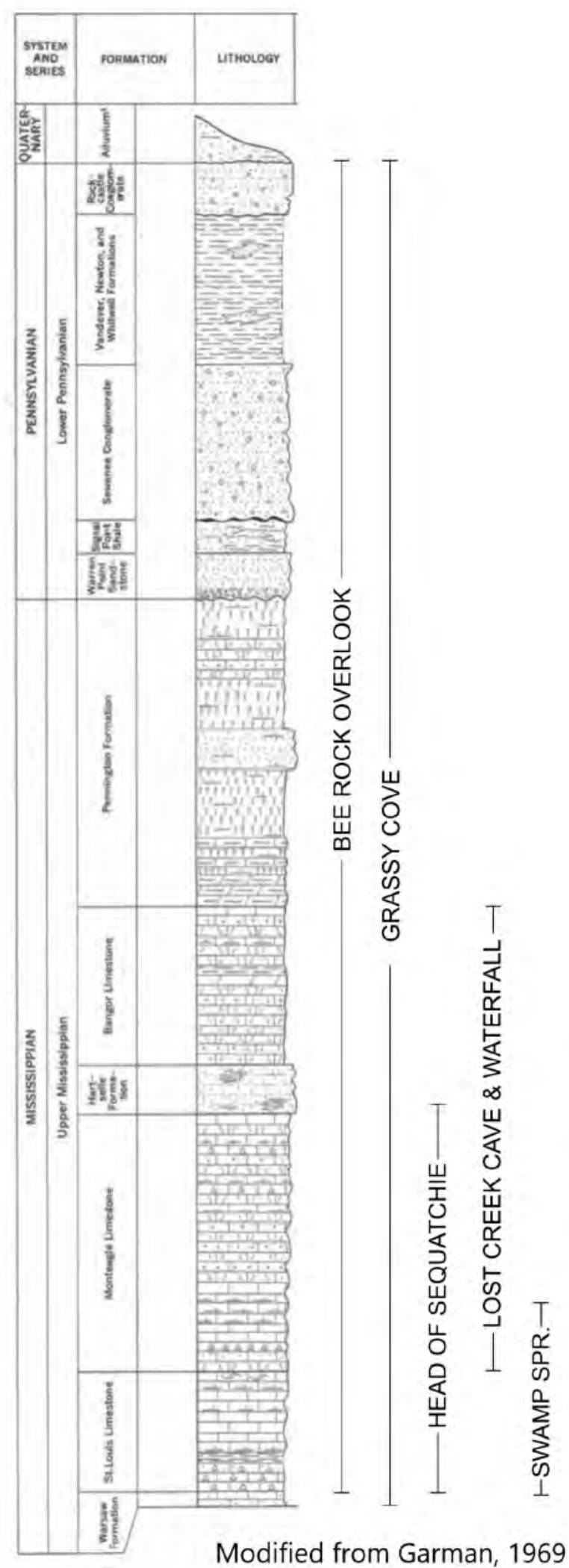

Figure 2. Stratigraphic column showing stratigraphic location of field trip stops. Note that the Fort Payne Formation referenced in the stratigraphy section is not shown on the stratigraphic column.

\section{Directions to Stop 1}

-From 1919 West End Ave., Nashville, TN: Take West End Ave. and Broadway to I-40 E: 1.3 kilometers $(\mathrm{km})$ or 0.8 miles (mi)

-Follow I-40 E to Exit 300: $146.9 \mathrm{~km}$ (91.3 mi)

-Turn right onto TN-84: $0.2 \mathrm{~km}(0.1 \mathrm{mi})$

-Turn left onto Bee Rock Road: 0.3 km (0.2 mi)

\section{Stop 1: Bee Rock in Monterey, Tennessee (N. $36.12903^{\circ}$, W. $85.28615^{\circ}$ )}

Bee Rock is an overlook and popular rock-climbing area that was recently purchased by the City of Monterey as a city park (fig. 3). The bluff face ranges from 24 to $30 \mathrm{~m}$ (79 to 98 $\mathrm{ft}$ ) in height and wraps around the nose of a small ridge. The bluff overlooks Stamps Hollow, which combines with Jake and Tayes Hollows to form the Calfkiller Valley (fig. 4). The Calfkiller Valley contains several hundred caves including Blue Springs Cave, the longest cave in Tennessee $(64.4 \mathrm{~km}$ [40 mi]). Although the topographic start of the Calfkiller River lies before us, the hydrologic origins of the river are more complex. A short distance away, on the north side of the town of Monterey, are the headwaters of the Falling Water River, which eventually flows over several impressive waterfalls at Burgess Falls State Park, over 48 km (30 mi) downstream. During baseflow conditions, the Falling Water River sinks at the contact between the Mississippian Hartselle Formation and the underlying Monteagle Limestone (fig. 4) (Jones, 2001). From this point, the water travels underneath the caprock of the Cumberland Plateau and is next encountered in the Yellow River of China Cave, a 6-km (3.7-mi)-long cave located down the Calfkiller Valley approximately $4 \mathrm{~km}(2.5 \mathrm{mi})$ from where we stand. From the Yellow River in China Cave, the water travels to Twenty Springs, a multiple-outlet spring system located along the Calfkiller River. During base-flow conditions these springs are the perennial start of the Calfkiller River.

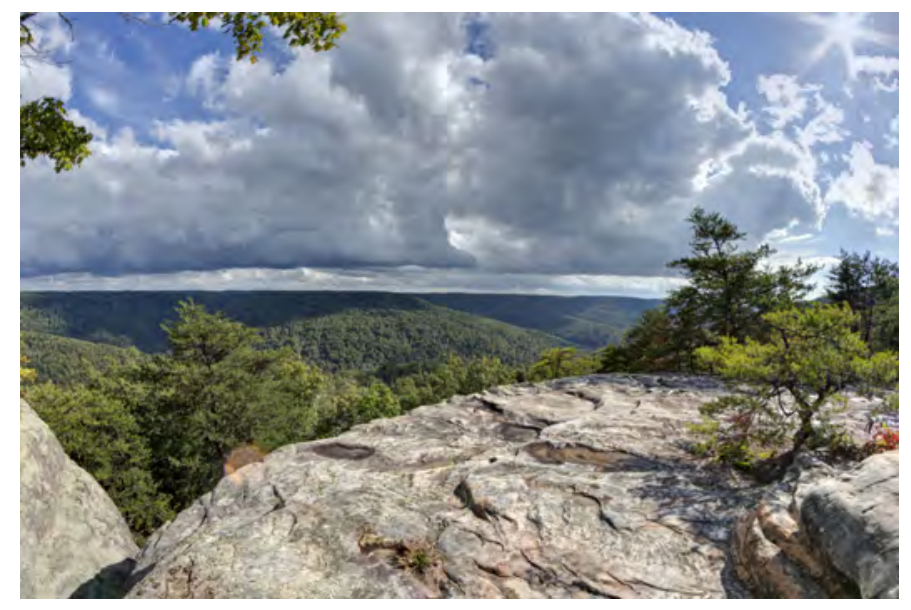

Figure 3. View from Bee Rock in Monterey, Tennessee, looking south-southwest into Stamps Hollow. Photo taken by Chuck Sutherland, October 3, 2014 (used with permission). 


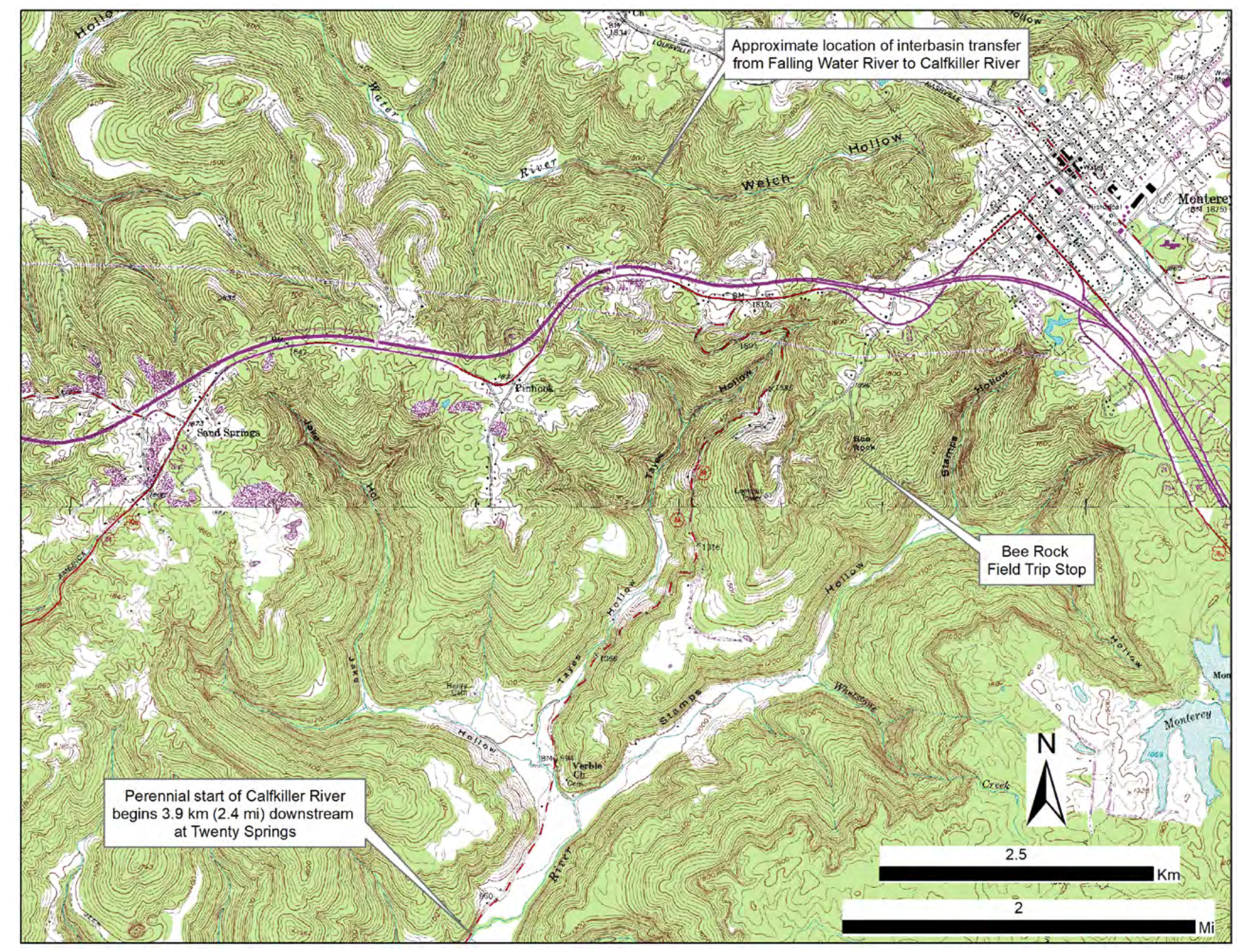

Figure 4. General overview of topography and referenced place names at field stop 1, Bee Rock, Monterey, Tennessee. Map compiled from 1:24,000-scale topographic quadrangle maps (individual 7.5-minute quadrangles: Monterey and Monterey Lake), 20-foot contour interval. 


\section{Directions to Stop 2}

\author{
-Proceed back to I-40 E: $0.5 \mathrm{~km}(0.3 \mathrm{mi})$ \\ -Follow I-40E to Exit 322: $34.3 \mathrm{~km}(21.3 \mathrm{mi})$ \\ -Turn right onto TN-101/TN-392: $4.5 \mathrm{~km}(2.8 \mathrm{mi})$ \\ -Turn left onto TN-127: $4.0 \mathrm{~km}(2.5 \mathrm{mi})$ \\ -Slight left onto TN-68 S: $11.6 \mathrm{~km}$ (7.2 mi) \\ -Turn right onto Kemmer Road and follow to Stop 2: 1.0 \\ $\mathrm{km}(0.6 \mathrm{mi})$
}

\section{Stop 2: Grassy Cove (N. $35.83827^{\circ}$, W. $84.92696^{\circ}$ )}

Grassy Cove is the largest closed depression in the USA (Palmer and Palmer, 2009), with an area of 65 square kilometers $\left(\mathrm{km}^{2}\right)$ and approximate dimensions of 13 by $5 \mathrm{~km}$ ( 8 by $3 \mathrm{mi}$ ) and an average depth of $304 \mathrm{~m} \mathrm{(1,000} \mathrm{ft).} \mathrm{Relief}$ can frequently exceed $457 \mathrm{~m}(1,500 \mathrm{ft}$ ) (figs. 5 and 6). Our visit to Grassy Cove will include driving around the inside of the giant closed depression and a stop at the historic Grassy Cove Community where an overview of the geology and discussion of the major karst components will take place.

The gigantic closed depression of Grassy Cove is an example of a headward migrating cove, which has occurred in the Sequatchie Valley as a result of large regional scale structural features (Milici, 1968). The Sequatchie Valley is an exceptionally straight valley formed along the axis of a major anticlinal fold. The overlying Pennsylvanian-age strata were breached by erosional processes that exposed the underlying softer Mississippian-age strata and caused incision of the valley and migration headward along the axis of the anticline. At the head of this anticlinal valley, the geomorphic processes are at an earlier stage of development compared with the broad Sequatchie Valley. The broad valley suddenly begins at a large spring that discharges from the base of Dorton Knob and Hinch Mountain, which have not yet eroded away to connect the large, closed depression of Grassy Cove with the Sequatchie Valley (figs. 6 and 7). Grassy Cove is the next major portion of the valley along the anticlinal axis.
The siliciclastic Pennsylvanian strata have already been breached, exposing the underlying Mississippian limestones and resulting in the karstification present throughout the cove. Upgradient along the axis of the anticline from Grassy Cove are several smaller coves that are at an even earlier stage of cove retreat: Little Cove, Bat Town Cove, and McClough Hollow (McClough Hollow is located off the map extent of figure 6). Beyond these smaller coves, the anticlinal structure plunges to the northeast forcing the more readily karstified limestones deeper underground in the Obed and Big South Fork River regions. This results in a general lack of caves in this area compared to other parts of the Cumberland Plateau.

Stratigraphically, the geologic units present in Grassy Cove are the same as those discussed in the introductory stratigraphy section and encountered at Bee Rock. The primary difference in Grassy Cove, compared to the rest of the Cumberland Plateau, is the large degree of faulting and structural deformation that has altered the otherwise nearly flat-lying geologic units. The floor of Grassy Cove consists of Mississippian-age Warsaw Limestone, with a small portion of the floor extending down into the Fort Payne Formation (Milici, 1965). The flanks of Grassy Cove are the same sequence found throughout the Cumberland Plateau. The upper formation in the sequence locally is the Pennsylvanian-age Vandever Formation near the top of Brady Mountain, extending down through the Mississippian-age St. Louis Limestone at the base of the slopes.

Hydrologically, Grassy Cove was one of the very first complex karst hydrologic systems to be studied intensively in Tennessee. In the early 1970s, Dr. Nicholas Crawford (Western Kentucky University) spent several years studying the hydrologic relations of the karst systems in and around Grassy Cove (Crawford, 1989). This work included extensive hydrologic monitoring, dye tracing, and geochemical analysis. From this work we have a much deeper understanding of the interrelations between the large and smaller scale hydrologic systems in and around Grassy Cove.

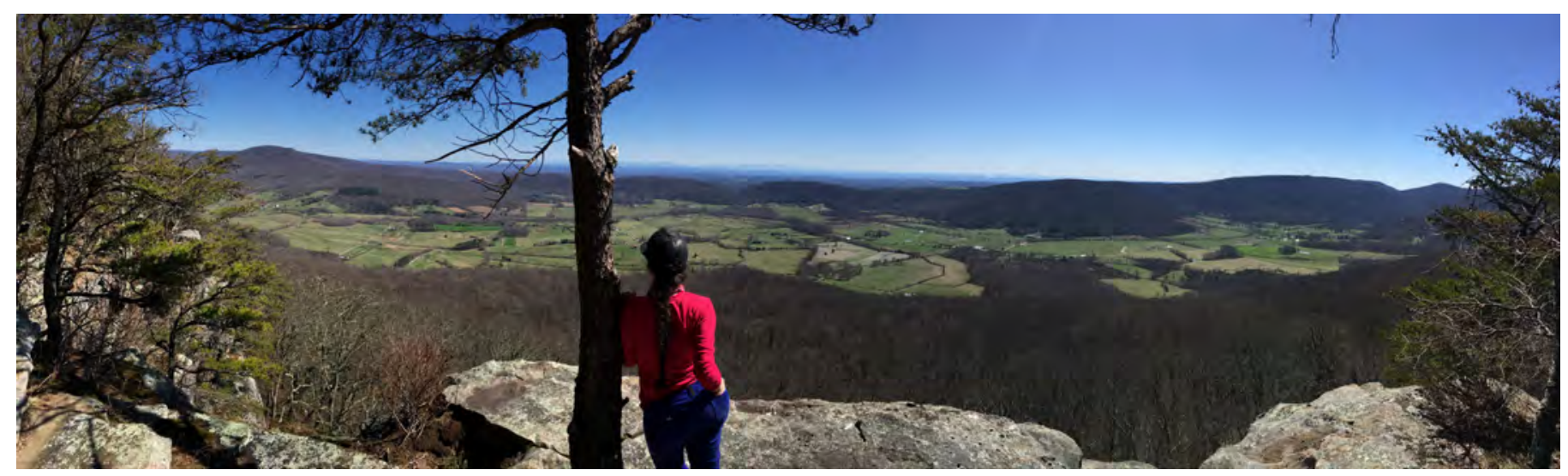

Figure 5. Grassy Cove as viewed from an overlook on Brady Mountain, Tennessee, looking southeast. Photo taken by Ben Miller, U.S. Geological Survey, December 17, 2019. 


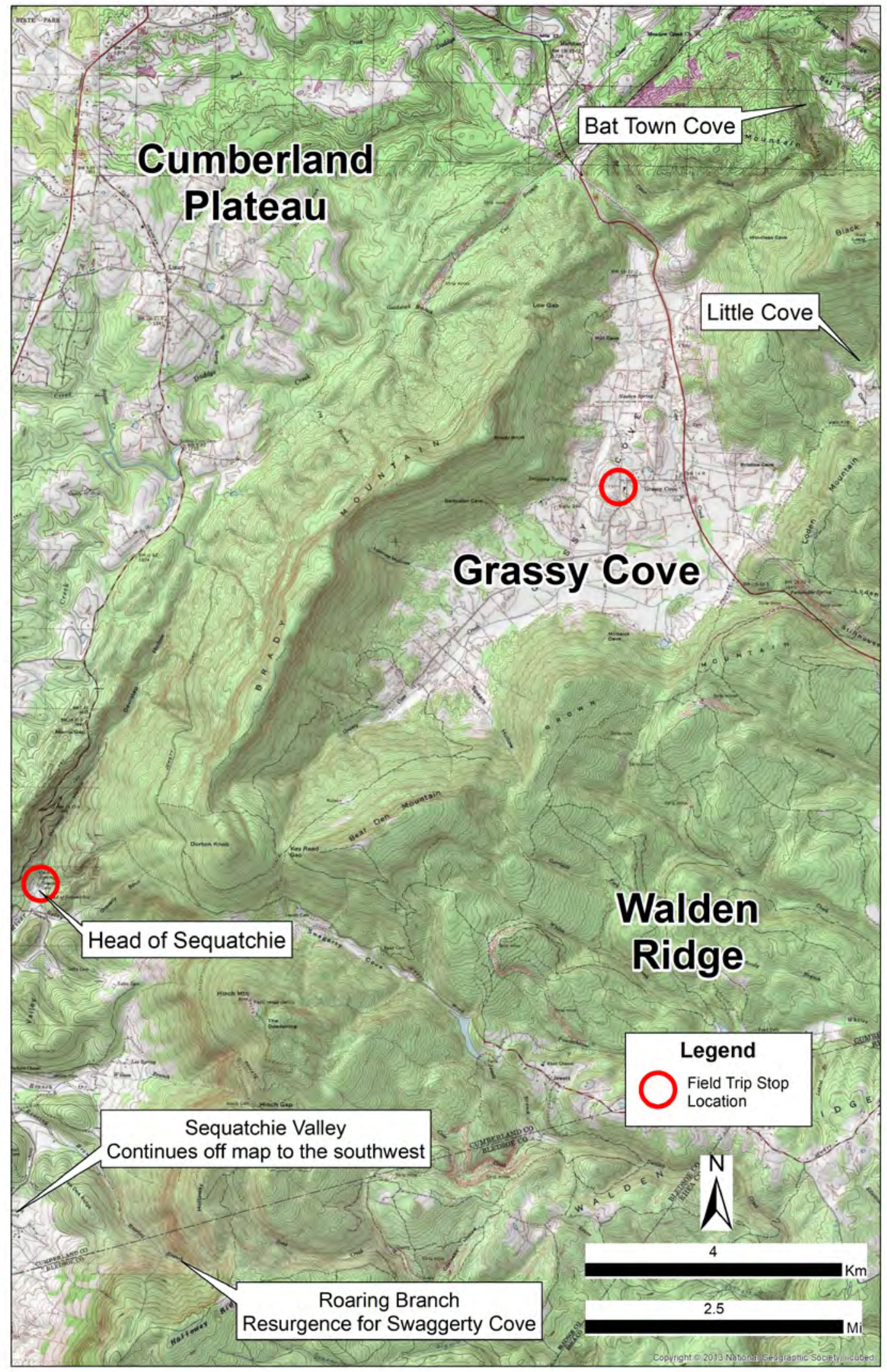

Figure 6. Overview map of the Grassy Cove and Head of Sequatchie area on the Cumberland Plateau, Tennessee. Map compiled from 1:24,000-scale topographic quadrangle maps (individual 7.5-minute quadrangles: Crossville, Dorton, Grassy Cove, Melvine, Pennine, and Vandever), 20-foot contour interval. 
Along the interior flanks of Grassy Cove are numerous smaller scale karst systems, such as the Milksick Cave-Bill Kemmer Spring system and the Windlass Cave-Boiling Springs system (locations not shown). Streams found in these smaller scale systems, in caves or sinking into caves, proceed rather rapidly through conduits to resurge at springs lower in elevation, which then flow across the floor of Grassy Cove towards Mill Cave (location not shown). Once water enters Mill Cave, the stream flows through $2 \mathrm{~km}$ (1.2 mi) of air-filled stream passages before the main passage ends at a large terminal breakdown. From this point, the water from Mill Cave and Grassy Cove is not encountered again for 7.8 $\mathrm{km}(4.8 \mathrm{mi})$, where the stream resurges in an enormous trunk passage 123 meters (405 feet) inside Run to the Mill Cave (Lane, 1979) (location not shown). The stream then flows through large passageways before eventually reaching a sump in a series of small breakdown rooms and passages. The water then flows to the spring complex at Head of Sequatchie, first reappearing at a karst window in Devilstep Hollow Cave before issuing from the main springs. The water that sinks at Mill Cave in Grassy Cove takes several days to resurge at Head of Sequatchie. It is the long unseen flow path from the breakdown in Mill Cave to the rise at Head of Sequatchie that has motivated cavers to search for the continuation of the elusive "Mill Trunk" and led to the discovery and exploration of many of the significant caves in the area. In addition to the large volume of water that sinks in Grassy Cove, there are three other smaller coves that contribute water to the flow system and are located farther north along the anticlinal axis: Little Cove and Bat Town Cove (fig. 6), and McClough Hollow (located northeast just off the map extent on figure 6). McClough Hollow is the northernmost of these minor coves and currently holds the record for the longest dye trace in Tennessee with a straight-line trace length of $15.5 \mathrm{~km}(9.6 \mathrm{mi})$ (Crawford, 1989).

Inside Grassy Cove are a total of 54 caves; however, directly adjacent and often associated with the hydrologic system of the cove are over 80 additional caves (Tennessee Cave Survey, 2019a). These caves range considerably in character, length, and depth, and several caves are worth noting. Mill Cave in the northern portion of Grassy Cove is the primary drain for Grassy Cove with $2 \mathrm{~km}(1.2 \mathrm{mi})$ of survey in large stream passages (Crawford, 1973b). Grassy Cove Saltpeter Cave and The Gouffre are two major caves (locations not shown) along the flank of Brady Mountain with $12.7 \mathrm{~km}(7.9 \mathrm{mi})$ and $3.4 \mathrm{~km}(2.1 \mathrm{mi})$ of surveyed passages, respectively (Sims, 1977; Anderson and Kambesis, 1992). The caves appear to be very closely related and at least hydrologically connected, although no humanly passable connection has been established. The area also has a high concentration of some of Tennessee's deepest caves, with at least seven caves that exceed $152 \mathrm{~m}$ (500 ft) in depth. Dorton Knob Smoke Hole (location not shown) contains the deepest single pit in Tennessee with Hidden Well, an 89-m (293-ft) drop near the bottom of the 201-m (660-ft)-deep cave (Green and Miller, 2014).

\section{Directions to Stop 3}

-Follow route back to TN-127 S: $12.4 \mathrm{~km}(7.7 \mathrm{mi})$

-Follow route to Linary Road: $3.4 \mathrm{~km}(2.1 \mathrm{mi})$

-Take left onto Linary Road/Old State Hwy 28 and follow to Park entrance: $11.9 \mathrm{~km}(7.4 \mathrm{mi})$

\section{Stop 3: Head of Sequatchie (N. $35.79350^{\circ}$, W. $85.00825^{\circ}$ )}

Head of Sequatchie is part of the Justin P. Wilson Cumberland Trail State Scenic Trail State Park system. This system of parks is a portion of the planned trail system to eventually provide a $454-\mathrm{km}(282-\mathrm{mi})$ trail from the Tennessee River Gorge at the southern end to Cumberland Gap at the northern terminus (Cumberland Trails Conference, 2020). The Head of Sequatchie tract consists of 156 hectares or 385 acres and includes the discharge features for the water that sinks in Grassy Cove. The spring group includes a main spring, Head of Sequatchie, and a major overflow spring, Devilstep Hollow Overflow Spring, which combined, are the perennial headwaters of the Sequatchie River (fig. 7). 


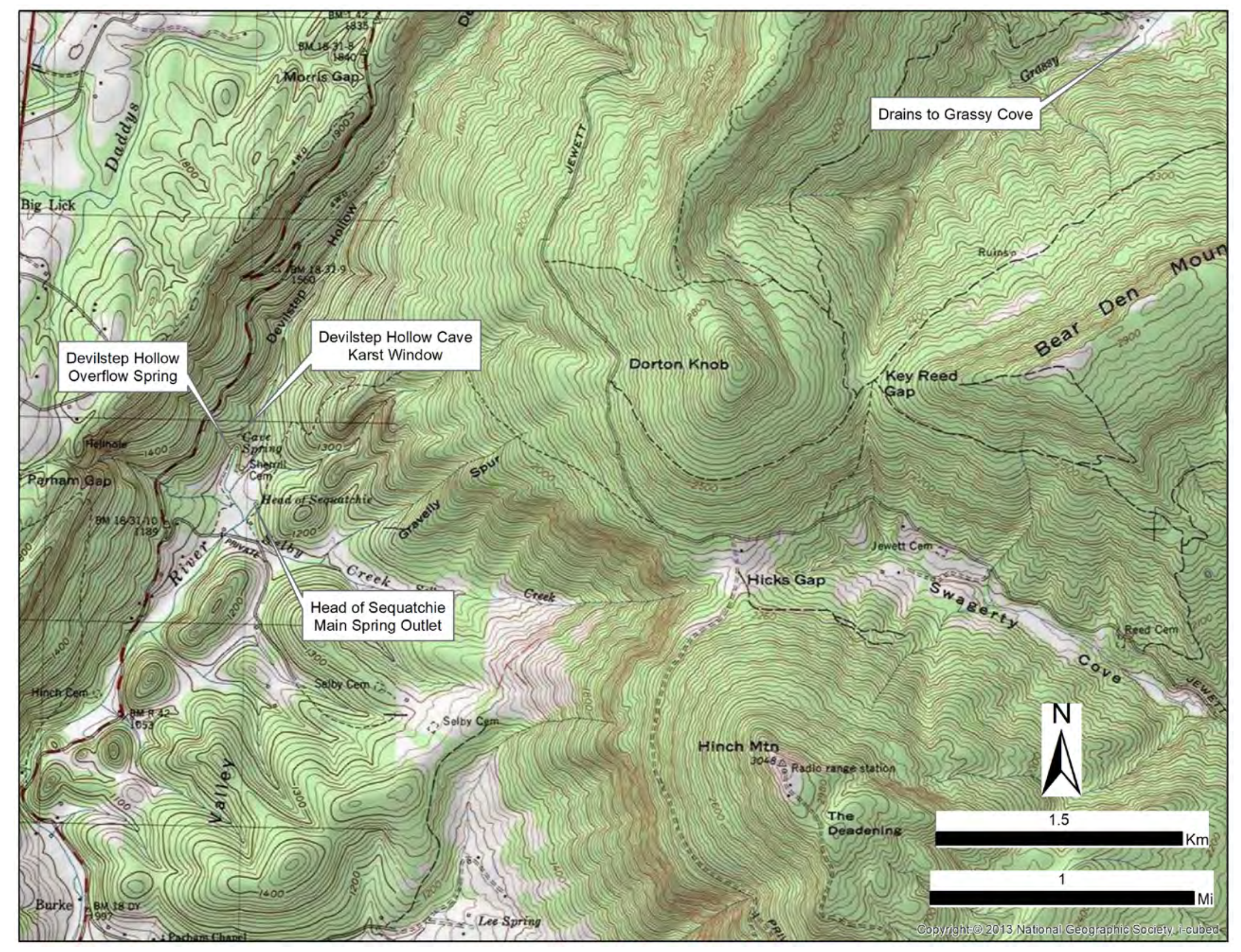

Figure 7. General overview of topography and referenced place names at field stop 3, Head of Sequatchie. Map compiled from 1:24,000-scale topographic quadrangle maps (individual 7.5-minute quadrangles: Grassy Cove and Vandever), 20-foot contour interval. 
The Head of Sequatchie area is situated in a rather tight cove-like setting beneath the peaks of Dorton Knob and Hinch Mountain (fig. 7). Hinch Mountain is the highest point on the Cumberland Plateau at $929 \mathrm{~m}(3,048 \mathrm{ft})$ in elevation, and the local relief of $600 \mathrm{~m}$ (1,968 ft) from Hinch Mountain down to Head of Sequatchie, is some of the highest relief in Tennessee outside of the Great Smoky Mountains. The water that discharges at the springs can first be seen in a deep blue pool in the large, impressive entrance to Devilstep Hollow Cave, a 786-m (2,578-ft)-long cave (Crawford, 1973a). The Monteagle Limestone is noticeably tilted at this location as well as at the main spring outlet downslope from the cave, dipping 10 to 25 degrees to the northwest. The dip is highly variable locally and the cave is a short distance downslope from a significant fault, referred to as the Devilstep Hollow Fault or the Mill Cave Fault (Milici, 1965; Moore and Milici, 1990). The water from the pool in the cave entrance then flows to the main spring at Head of Sequatchie (fig. 8). However, during times of high flow this water will also emerge at Devilstep Hollow Overflow Spring immediately downslope from the cave (fig. 9). The main spring discharges into a man-made millrace from a small cave that was mapped to $45 \mathrm{~m}$ (149 ft) by the authors during a 2016 drought (fig. 10; Miller, 2016). The discharge from the spring does not vary considerably, normally discharging from 0.6 to 0.7 cubic meters per second $\left(\mathrm{m}^{3} / \mathrm{s}\right)\left(20\right.$ to 25 cubic feet per second $\left.\left[\mathrm{ft}^{3} / \mathrm{s}\right]\right)$ and typically not exceeding $1 \mathrm{~m}^{3} / \mathrm{s}\left(35 \mathrm{ft}^{3} / \mathrm{s}\right)$. This may be the result of a constricted orifice between Devilstep Hollow Cave and the spring that limits the volume of discharge to the main spring outlet. The overflow spring can discharge a tremendous amount of water during floods, measured by the authors at $4.2 \mathrm{~m}^{3} / \mathrm{s}\left(150 \mathrm{ft}^{3} / \mathrm{s}\right)$, though the spring becomes non-wadeable at flows above this discharge. The overflow spring discharges from rubble at the base of several small rock outcrops, though observations in drier periods noted this rubble appears to be filling multiple small conduits.

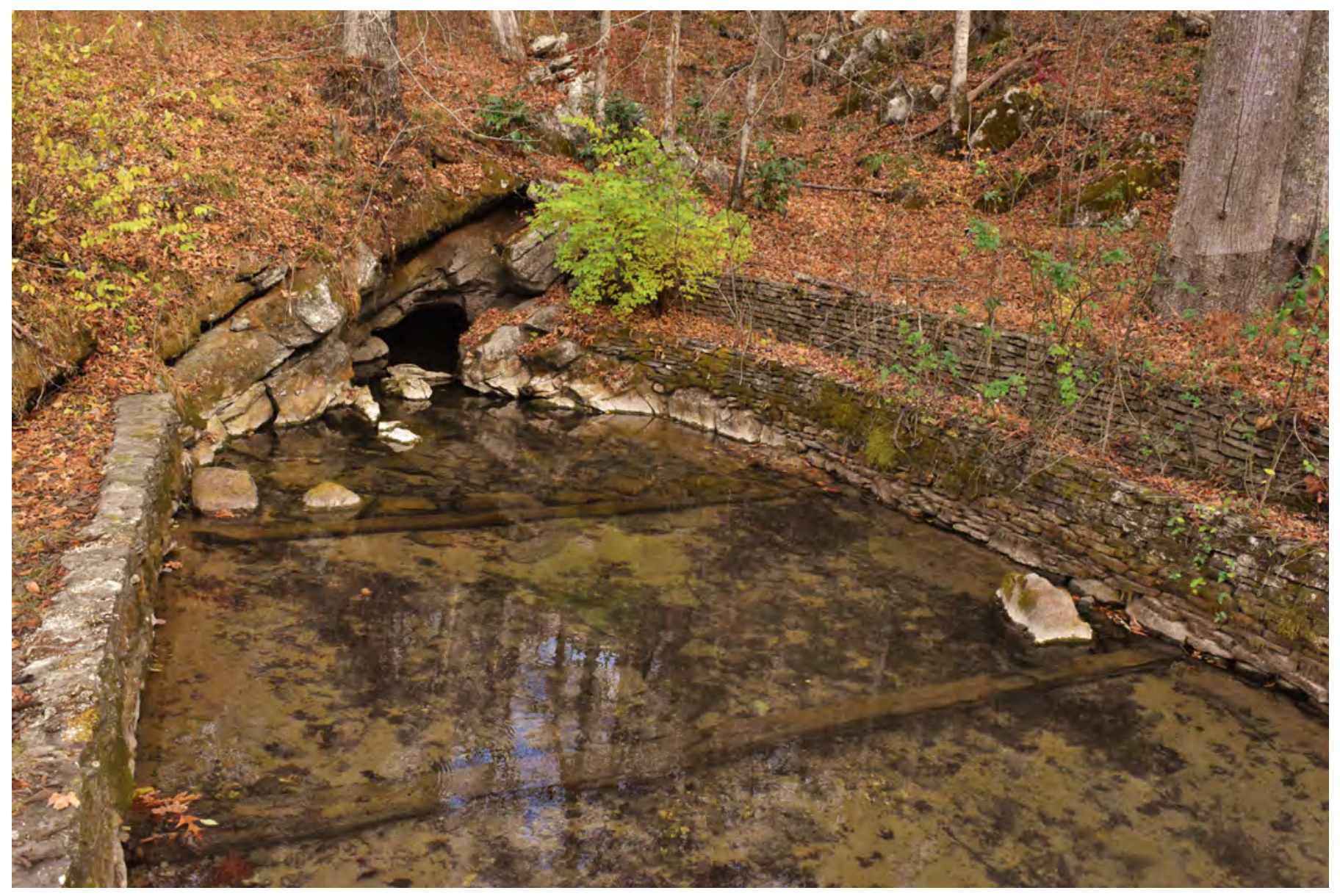

Figure 8. Head of Sequatchie main spring, Head of Sequatchie State Park, Tennessee. Note the dipping beds of Monteagle Limestone at the springhead. Photo taken by Brian Ham, Tennessee Department of Environment and Conservation, November 27, 2016. 


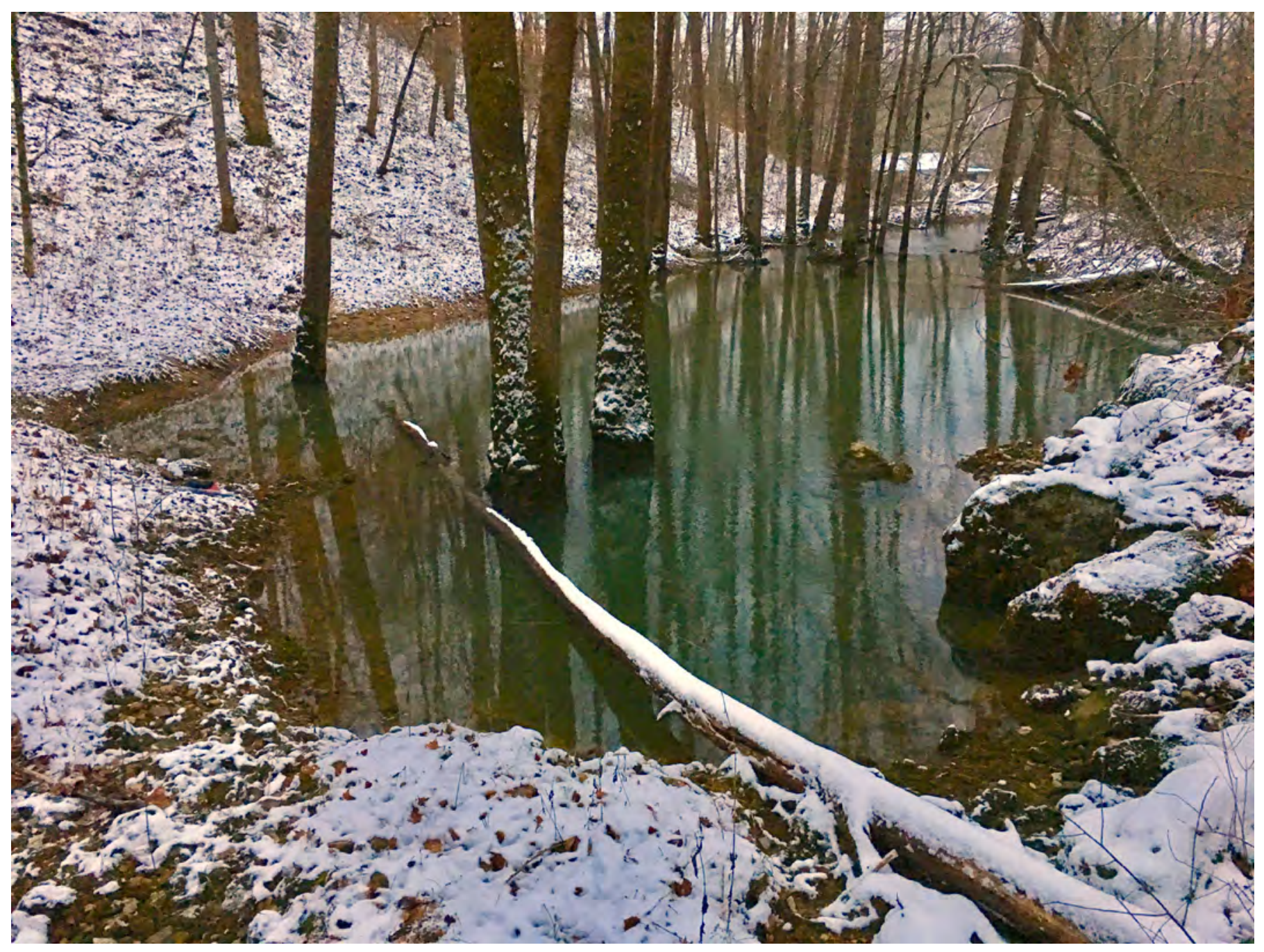

Figure 9. Devilstep Hollow Overflow Spring discharging during winter at Head of Sequatchie, Tennessee. Photo taken by Brian Ham, Tennessee Department of Environment and Conservation, January 6, 2017.

Monitoring of flow conditions at Head of Sequatchie Spring with instrumentation at both the main outlet and overflow springs began in June 2016 by the Karst Springs Initiative, a citizen science group focused on spring studies. The visit to Head of Sequatchie will include walking to the primary resurgence and the overflow resurgence with a discussion of research being conducted on the hydrology of the area. Lunch for the group will take place at this site, and the field trip leaders will take the opportunity to discuss in more depth the tracing that was previously conducted to delineate the recharge area for Head of Sequatchie Spring. This discussion will include dye tracing results of injections at McClough Hollow, Bat Town Cove, and Mill Cave in Grassy Cove, all of which are recharge areas for the spring. The overview will also include a discussion of dye tracing from Swagerty Cove, which established a connection between the cove and the nearby rise of Roaring Branch and helped to define the groundwater basin divide for Head of Sequatchie Spring.

Devilstep Hollow Cave is also a significant archeological resource exhibiting some of the most unique cave art in the state, including petroglyphs, pictographs, and mud glyphs. Dr. Jan Simek (University of Tennessee-Knoxville) along with other members of the archeological community have thoroughly researched the significance of this cave art site along with other sites in Tennessee and the southeastern U.S. (Simek and others, 2001). A brief discussion of the cave art found in Devilstep Hollow Cave will be provided to highlight the importance of this resource. 


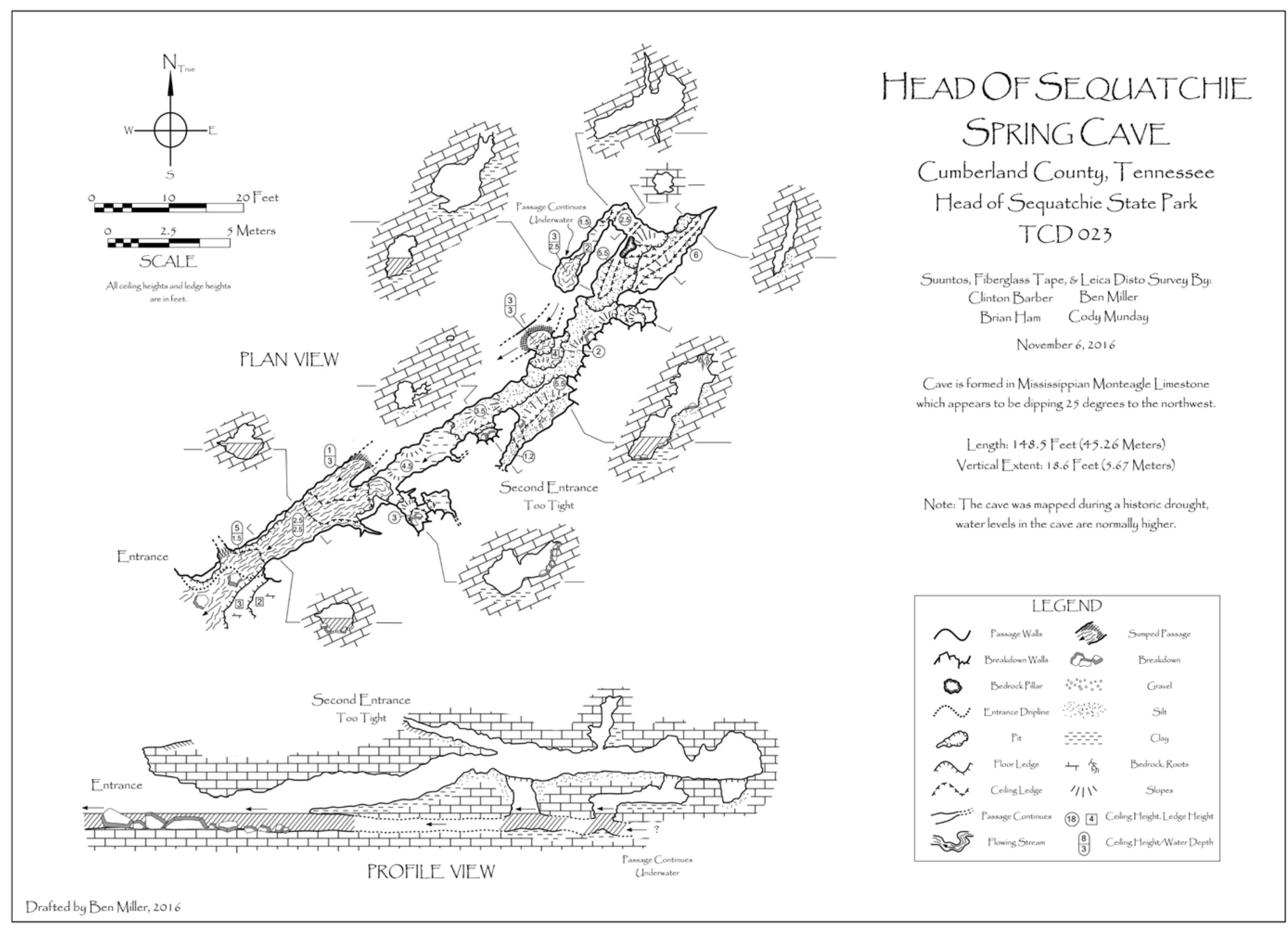

Figure 10. Map of Head of Sequatchie Spring Cave, Head of Sequatchie State Park, Cumberland County, Tennessee. 


\section{Directions to Stop 4}

-From Stop 3, continue on Old State Hwy 28: 10.8 km (6.7 $\mathrm{mi})$

-Turn left onto State Hwy 509 and follow to TN-127 S: $2.6 \mathrm{~km}(1.6 \mathrm{mi})$

-Turn left and follow TN-127 S to TN-30 W: $19.6 \mathrm{~km}$ (12.2 mi)

-Turn right onto TN-30W: $29.3 \mathrm{~km}(18.2 \mathrm{mi})$

-Turn left onto TN-285 W: $8.7 \mathrm{~km}(5.4 \mathrm{mi})$

-Turn right onto Hickory Valley Road: 2.7 km (1.7 mi)

-Turn right onto Big Bottom Road and follow to Stop 4: $6.9 \mathrm{~km}(4.3 \mathrm{mi})$

\section{Stop 4: Lost Creek Cave and Waterfall (N $35.84088^{\circ}$, W $85.36104^{\circ}$ )}

During this stop, participants will visit Lost Creek Falls and Lost Creek Cave (fig. 11). Lost Creek State Natural Area was established by the State of Tennessee in 2012 and now provides access to this unique karst feature for the public.

The water seen at the main waterfall at Lost Creek Falls originates from a short cave, Lost Creek Resurgence Cave (91 m or $300 \mathrm{ft}$ in length) (location not shown), formed in the Bangor Limestone. Shortly downstream, the water flows over the Hartselle Formation-Monteagle Limestone contact as an $18-\mathrm{m}(60-\mathrm{ft})$ waterfall and sinks immediately, though during high flows the stream continues over the surface for a distant of approximately $120 \mathrm{~m}(400 \mathrm{ft})$ before entering the spacious Lost Creek Cave entrance, formed in the Monteagle Limestone. This uniquely vertical expression of a karst window between these geologic horizons is seen at other locations on the Cumberland Plateau, including nearby Virgin Falls (fig. 11), and was also documented in the models of plateau escarpment development by Crawford in the 1970s (Crawford, 1987). This stop is a great place for photographers as shown by the panorama photo of a high flow event taken by Tim Curtis in December 2015 (fig. 12).

The Lost Creek Cave system includes four hydrologically connected caves (fig. 13; Tennessee Cave Survey, 2019b). Lost Creek Cave is $5.7 \mathrm{~km}$ (3.52 mi) long and the main entrance is situated across from Lost Creek Waterfall in the $45-\mathrm{m}$ (150-ft)-deep sinkhole. The entrance is approximately $30 \mathrm{~m}$ $(100 \mathrm{ft})$ wide and $18 \mathrm{~m}(60 \mathrm{ft})$ tall. A grist mill was historically situated at the entrance and there is evidence of Civil War era saltpeter mining in several of the passages. Approximately $914 \mathrm{~m}(3,000 \mathrm{ft})$ inside the cave, a $12-\mathrm{m}$ (40-ft) waterfall is encountered, which is the same water that is sinking at the base of Lost Creek Waterfall outside of the cave.

Your Cave (location not shown) contains $5.6 \mathrm{~km}$ (3.46 mi) of passage and has four different entrances. Although significant exploration and survey were conducted in an attempt to connect this cave with Lost Creek Cave, these two caves remain unconnected, although they are part of the same hydrologic system (Crawford, 1987). The cave has a vertical extent of $80 \mathrm{~m}(262 \mathrm{ft})$, similar to the vertical extent of Lost Creek Cave at $73 \mathrm{~m}(240 \mathrm{ft})$.

Merrybranch Cave (location not shown) is located about $914 \mathrm{~m}(3,000 \mathrm{ft})$ southwest of Lost Creek Cave on the southeast side of Pine Mountain. The entrance is $12 \mathrm{~m}(40 \mathrm{ft})$ high and $6 \mathrm{~m}(20 \mathrm{ft})$ wide and is situated $6 \mathrm{~m}(20 \mathrm{ft})$ above where the streambed flows over the Hartselle FormationMonteagle Limestone contact. The large entrance is formed in a bluff face of the Bangor Limestone with a stream flowing over breakdown. The cave approaches $1.2 \mathrm{~km}(4,000 \mathrm{ft})$ of total length, and the majority of the cave consists of $914 \mathrm{~m}$ $(3,000 \mathrm{ft})$ of main cave passage with average dimensions of $6 \mathrm{~m}(20 \mathrm{ft})$ wide and $3 \mathrm{~m}(10 \mathrm{ft})$ tall.

Dry Creek Falls Cave (location not shown) has been surveyed to a length of $777 \mathrm{~m}(2,550 \mathrm{ft})$ and has a vertical extent of $43 \mathrm{~m}(140 \mathrm{ft})$. The cave entrance is located on the northwest side of the valley, and the entrance consists of a

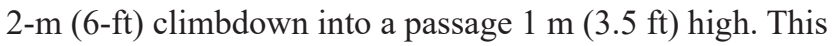
crawl leads to a large breakdown room and the main stream is located below. There are two pits in the cave that are $23.7 \mathrm{~m}$ $(78 \mathrm{ft})$ and $12 \mathrm{~m}(40 \mathrm{ft})$ deep, respectively. A lower stream passage continues before eventually becoming too low to traverse, though this portion of the cave is trending in the direction of the end of surveyed passages in Your Cave.

As part of Crawford's research, he conducted dye tracing at Lost Creek Cove, Lost Creek Cave, Dry Creek, and Your Cave (fig. 14). The recharge area for the water seen at Lost Creek Waterfall originates in Dog Cove, a portion of the Natural Area recently acquired by the State of Tennessee. The water from Dog Cove sinks at a major swallet at the southern end of Lost Creek before resurging at Lost Creek Resurgence Cave. The water from the Lost Creek Cave system then follows a subsurface route under Dry Creek prior to rising at "the Pools" within the Caney Fork River channel at the downstream end of Big Bottom before sinking again during baseflow and then rising at Island Spring (Crawford, 1987). 


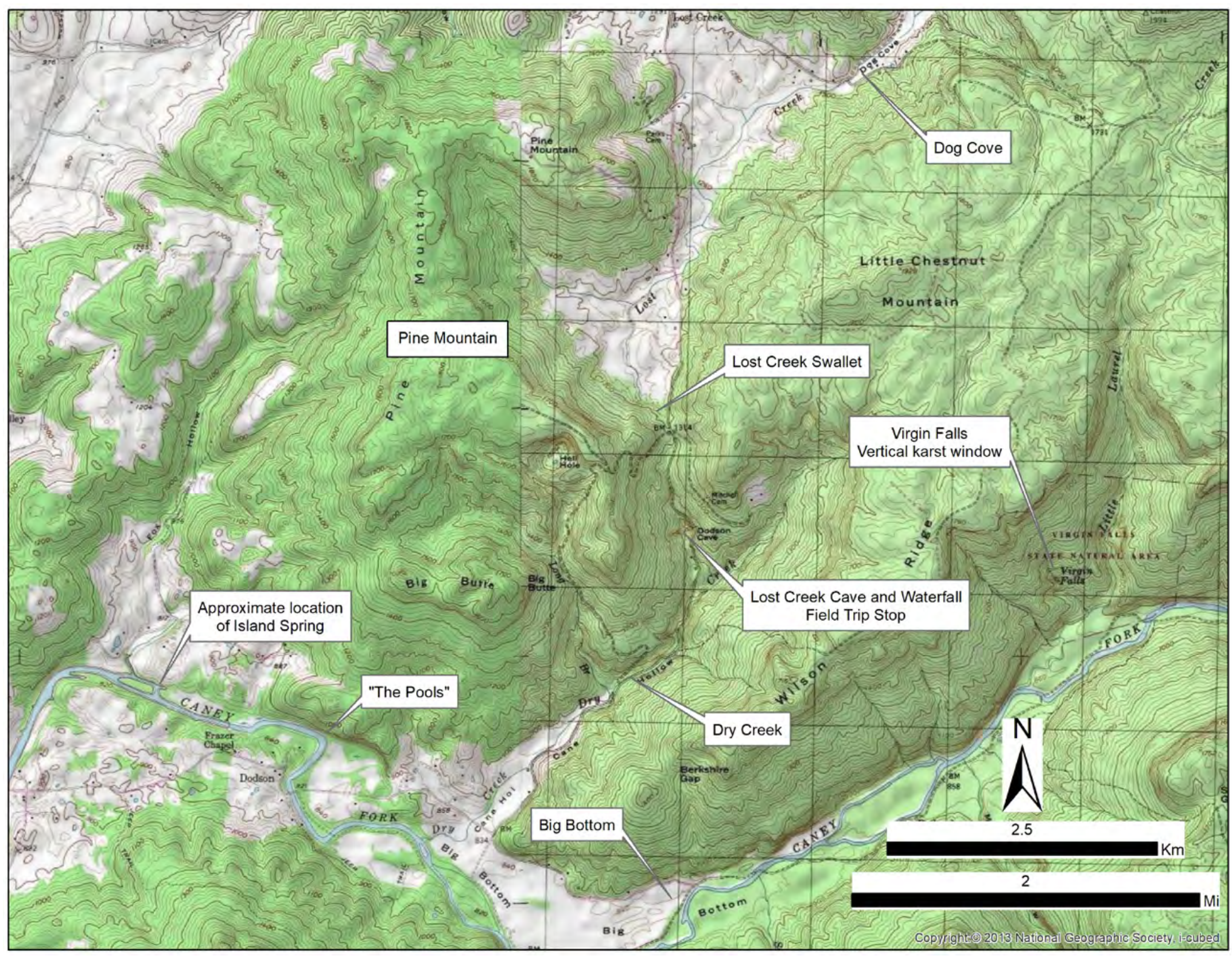

Figure 11. General overview of topography and referenced place names at field stop 4, Lost Creek Cave and Waterfall, Tennessee. Map compiled from 1:24,000-scale topographic quadrangle maps (individual 7.5-minute quadrangles: Bald Knob, Lonewood, Rossett, and Sparta), 20-foot contour interval. 


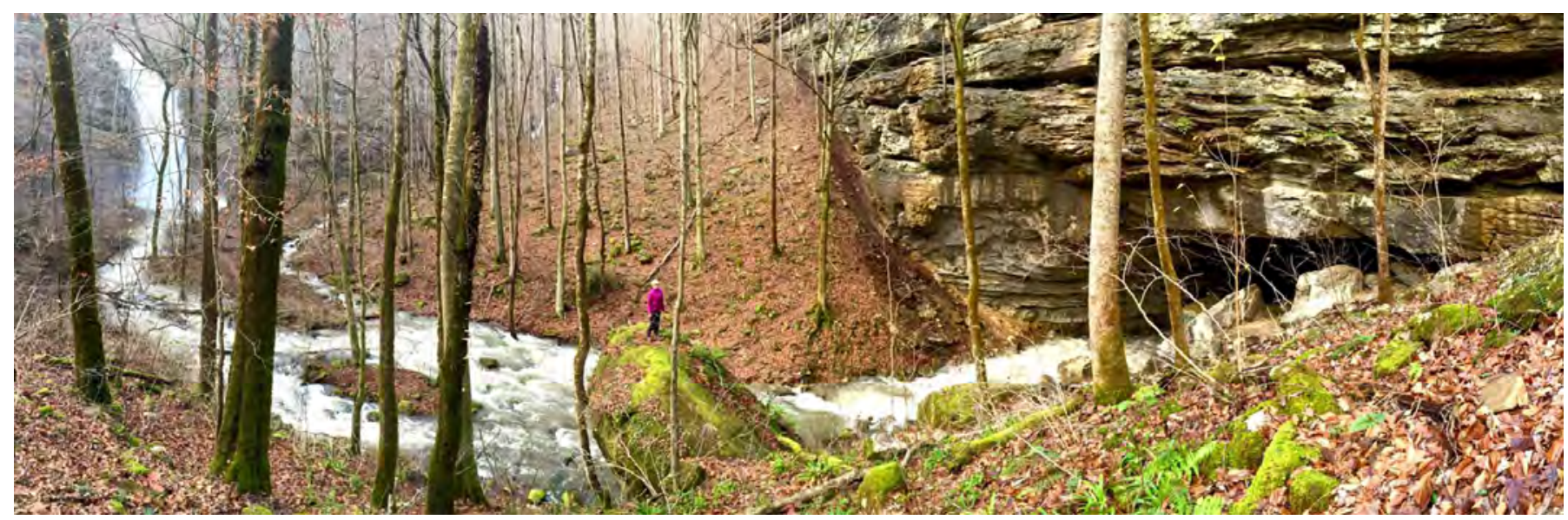

Figure 12. Lost Creek Waterfall and Cave, Lost Creek State Natural Area, during a 2015 flood event. Photo taken by Tim Curtis, December 2015 (used with permission). 


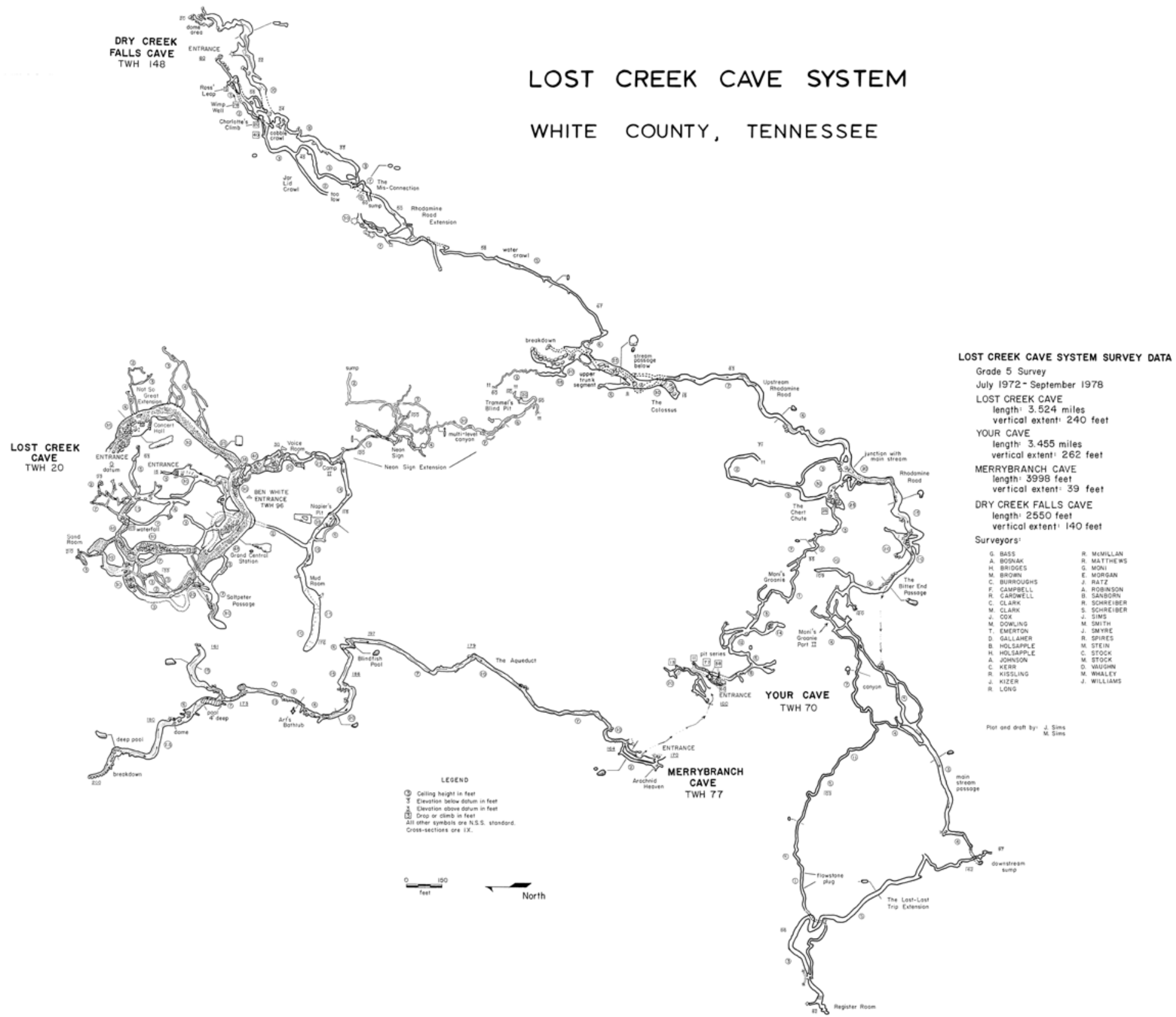

Figure 13. Map of Lost Creek Cave System, White County, Tennessee. Map by Jeff and Michelle Sims, Tennessee Cave Survey (used with permission). 


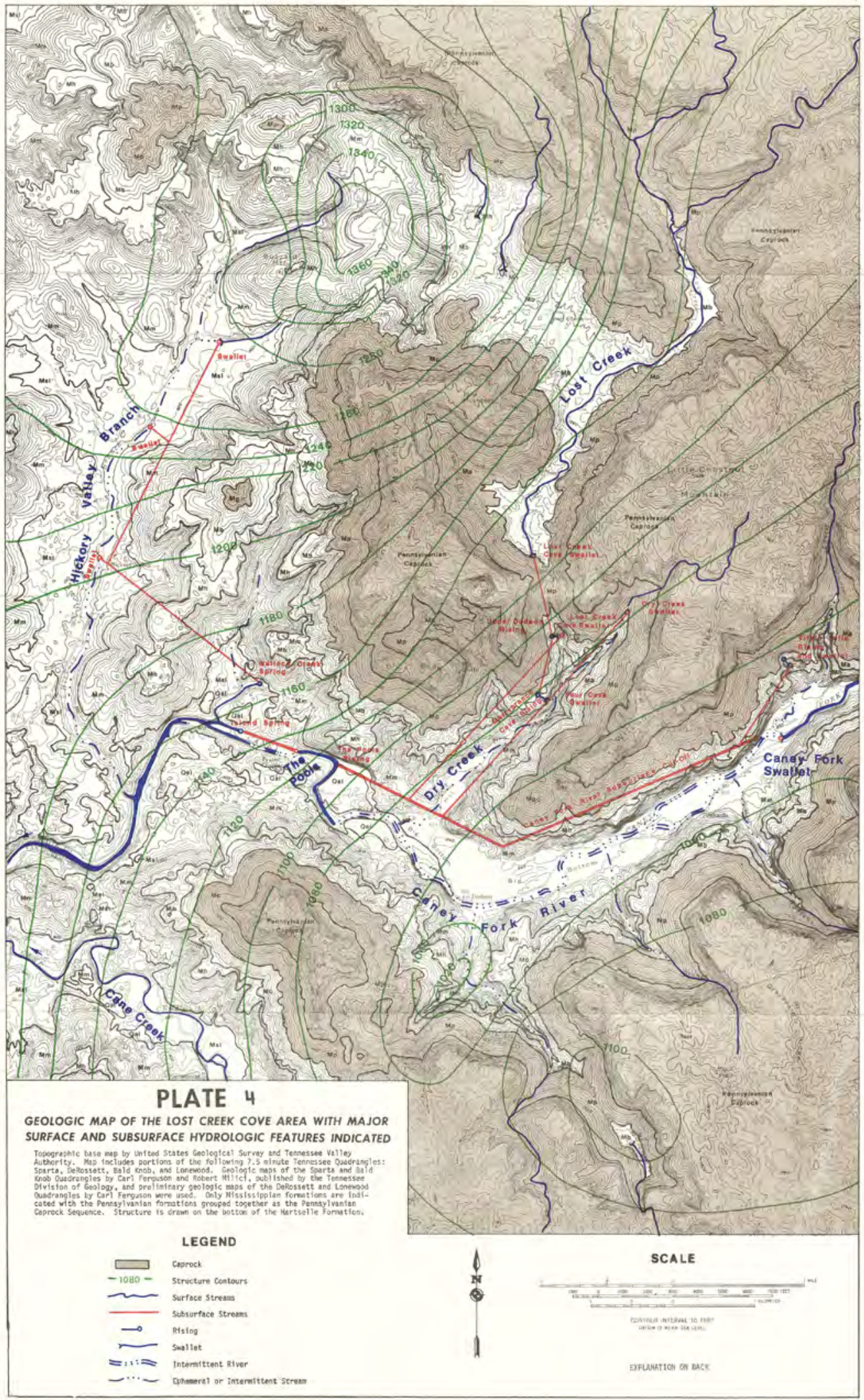

Figure 14. Hydrogeological map of the Lost Creek Cove area, Tennessee (Crawford, 1982). 


\section{Directions to Stop 5}

-Follow Big Bottom Road back to TN-285 W: 9.7 km $(6.0 \mathrm{mi})$

-Turn right onto $\mathrm{TN}-285 \mathrm{~W}$ to Stop 5: $1.6 \mathrm{~km}(1.0 \mathrm{mi})$

\section{Stop 5: Swamp Spring (N. $35.80243^{\circ}$, W. $85.44439^{\circ}$ )}

This is an optional stop, if time allows.

Swamp Spring is a large spring located at the northern end of Spencer Mountain, a highly dissected lobe of the Cumberland Plateau (fig. 15). The spring discharges at the head of a $0.7-\mathrm{km}$ (0.4- mi)-long channel with multiple overflow springs (fig. 16) and some wetlands before draining into Cane Creek, a major tributary to the upper Caney Fork River. Recent studies by the Karst Springs Initiative have shown the spring to be one of the largest in the state. The discharge can be extremely variable, with flows that range from $0.2 \mathrm{~m}^{3} / \mathrm{s}\left(8 \mathrm{ft}^{3} / \mathrm{s}\right)$ to $7 \mathrm{~m}^{3} / \mathrm{s}\left(250 \mathrm{ft}^{3} / \mathrm{s}\right)$. Additionally, the spring is seasonally inundated by nearby Great Falls Lake for extended periods of time. The Karst Springs Initiative is currently developing a stage-discharge relation for the spring and has a pressure transducer installed to monitor stage and temperature at 30-minute intervals.

The recharge area for Swamp Spring lies to the south and includes the western half of an impressive karst system, referred to herein as the Cane Creek karst system (fig. 17), which includes some of the more renowned caves in Tennessee. Notable to the Swamp Spring system is Rumbling Falls Cave, a 26-km (16.1-mi)-long stream cave with enormous rooms, a 61-m (201-ft) drop, and a large river that can be followed for $6.4 \mathrm{~km}$ (4 mi) (Swartz, 2002; Smith, 2017; Marion Smith, 2019, oral commun.). The cave, which is one of the most significant speleological discoveries in the past 25 years in Tennessee, was the center of controversy when the nearby city of Spencer planned to discharge sewage effluent into Dry Creek, a major sinking stream that contributes significant flow to the cave (Jones and others, 2002). This plan by the city that was later approved by the State of Tennessee was the impetus for dye tracing studies that delineated the Swamp Spring recharge area (fig. 17) (Jones and others, 2002). The results from the studies indicated that the plan would damage the fragile ecosystem within Rumbling Falls Cave; thus, the permit to discharge the effluent into Dry Creek was ultimately denied.

There are multiple sink points in nearly all the valleys of the surrounding area, some of which are near the Pennington Formation-Bangor Limestone contact, others of which are at the Hartselle Formation-Monteagle Limestone contact. Often these swallets may drain to different karst systems even though they are in the same topographic valley. Such is the case with Cane Creek where the upper swallets drain to the east to the Cane Creek Spring/Crusher Hole system, and some of the lower sink points contribute flow to the Swamp Spring system (fig. 17).

The karst system that runs along the eastern portion of Cane Creek includes several major cave systems: Rice Cave (13.8 km, $8.6 \mathrm{mi}$ ) (Smyre, 2008), Davis Tire Cave (2 km, $1.2 \mathrm{mi})$, Camps Gulf Cave (12.6 km, $7.8 \mathrm{mi})$, and Cueva Guapa Delnorte $(6.4 \mathrm{~km}, 4 \mathrm{mi})$. The most famous of these systems is Camps Gulf Cave, which has some of the largest rooms of any cave in the U.S. and is located at the downstream end of the eastern portion of the karst system. This system discharges at Cane Creek Spring, also known as Crusher Hole, located immediately downstream of the confluence of Camps Gulf Branch with Cane Creek and is approximately $10.8 \mathrm{~km}$ (6.7 mi) upstream from Swamp Spring (figs. 15 and 17).

The western karst system that recharges Swamp Spring begins largely with Dry Creek, which drains the uplands south of Spencer before dropping into a large gorge-like valley. A dye injection done during low base-flow conditions from a swallet near the Pennington Formation-Bangor Limestone contact took approximately 22 days to reach the main stream in Rumbling Falls Cave and an additional 10 days to reach Swamp Spring; during higher flows this travel time would likely be an order of magnitude less (Sid Jones, 2019, oral commun.). Water was also traced to Rumbling Falls Cave from the Black Rock River Cave-Windy River Cave system along the western flank of Cane Creek, which drains lower swallets on Cane Creek as well as Indian Camp Branch, a side tributary to Cane Creek (figs. 15 and 17). In addition to the major recharge contributions of Dry Creek and Cane Creek, recharge also was contributed from McKeever Cave (305 m, $1000 \mathrm{ft})$ and a large internally drained karst "valley," Turkey Cot Cove (figs. 15 and 17). Notably, these features appear to initially drain south, down-dip and perched on the Hartselle Formation. At a point near or upstream of Rumbling Falls Cave, this flow breaches the Hartselle Formation, then the cave stream flows north for $6.4 \mathrm{~km}$ (4 mi) through a large river trunk passage (fig. 18) towards base level and apparently going against or up-dip. After flowing through Rumbling Falls Cave, the stream sumps and re-emerges in Swamp River Cave (6.4 $\mathrm{km}$ or $4 \mathrm{mi}$ ) before finally resurging at Swamp Spring. Although the underground flow path of the stream from Dry Creek through Rumbling Falls Cave is not significantly longer (approximately $11.6 \mathrm{~km}$ or $7.2 \mathrm{mi}$ ) than other similarly large karst systems, it is unique in that greater than 65 percent of the length can be humanly traversed, mostly through very large passage (fig. 18). 


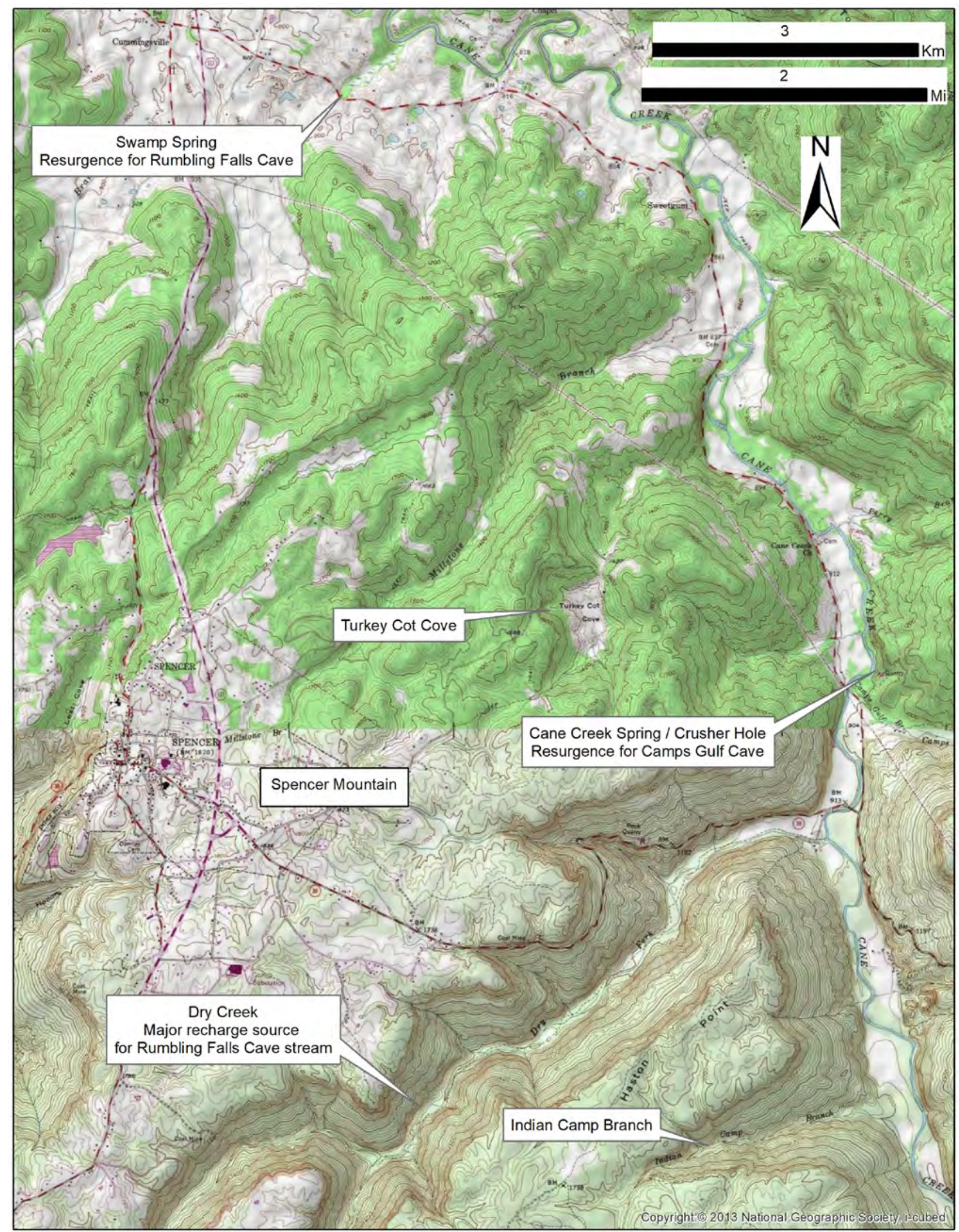

Figure 15. General overview of topography and referenced place names at field stop 5, Swamp Spring, Tennessee. Map compiled from 1:24,000-scale topographic quadrangle maps (individual 7.5-minute quadrangles: Bald Knob and Spencer), 20-foot contour interval. 


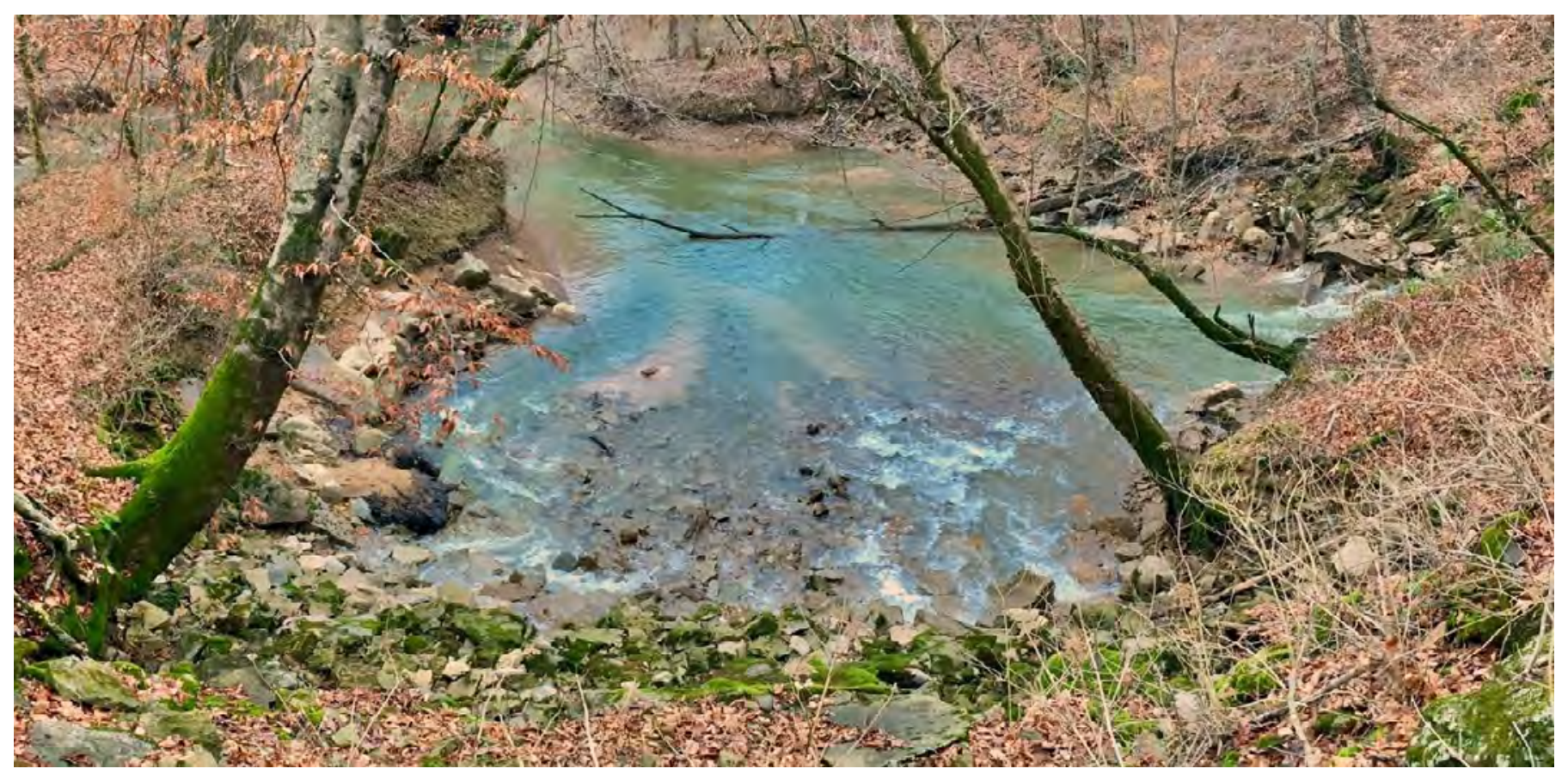

Figure 16. The main springhead at Swamp Spring. Additional overflow springs can be seen entering downstream of the main outlet along the right bank. Photo taken by Brian Ham, Tennessee Department of Environment and Conservation, November 27, 2016. 


\section{Spencer Area Karst Hydrology Van Buren Co., Tennessee}

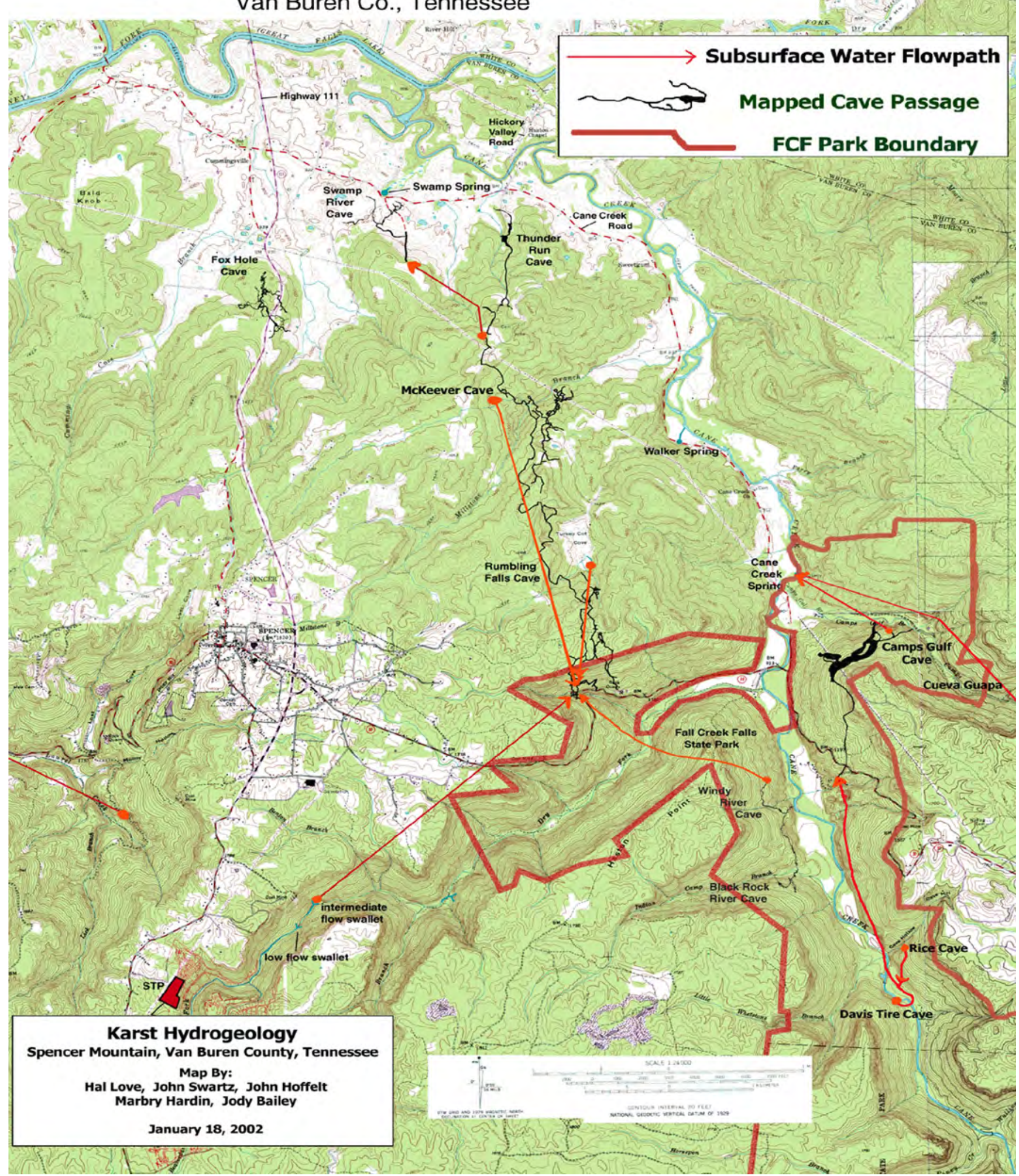

Figure 17. Hydrogeological map of the Spencer Mountain/Cane Creek karst system, Van Buren County, Tennessee. Map by Sid Jones, 2002, modified from Love and others, 2002 (used with permission). 


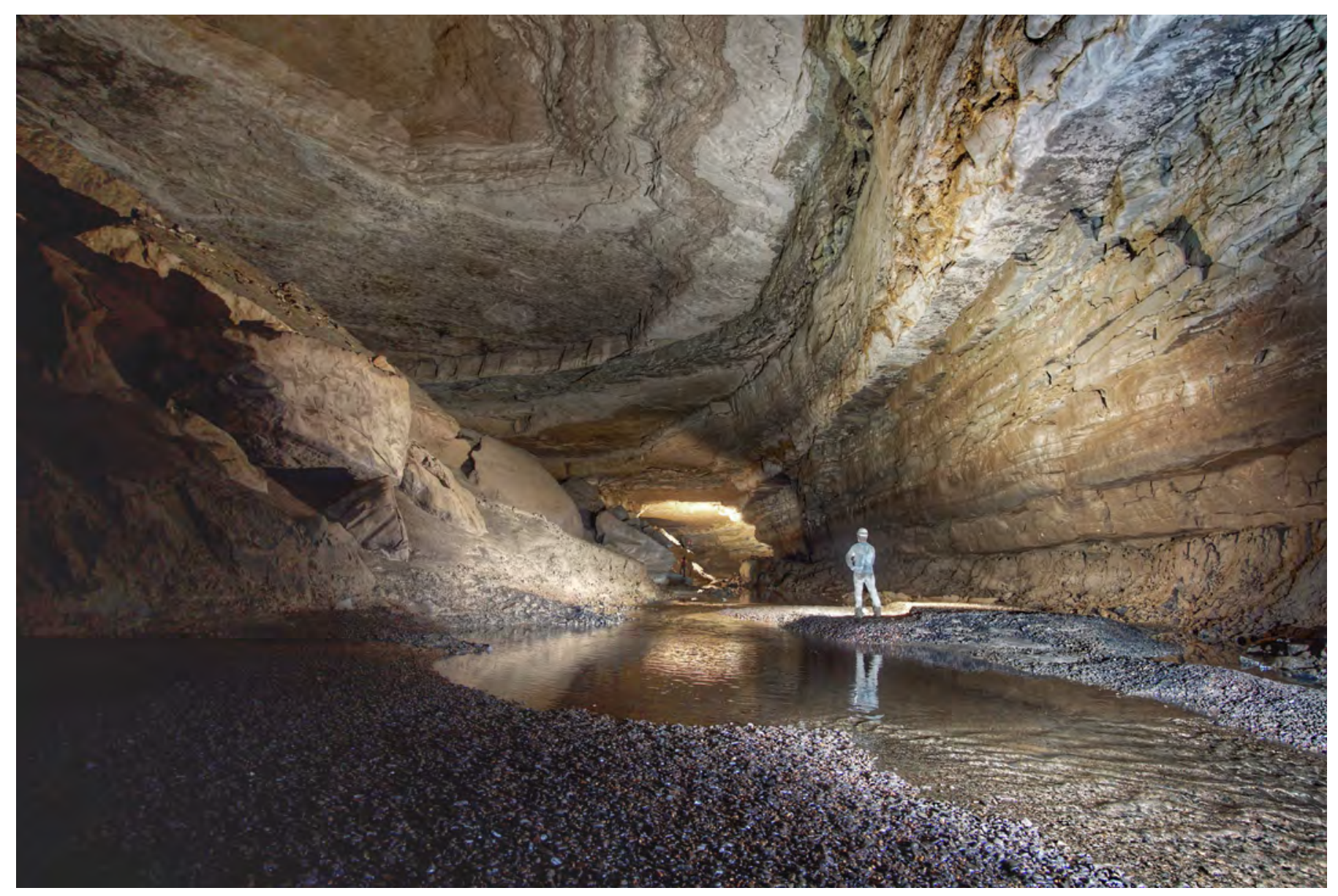

Figure 18. Large river passage in Rumbling Falls Cave during low-flow conditions. The cave is a primary recharge contributor to the Swamp Spring system. Photo taken by Jim Fox, September 27, 2017 (used with permission).

\section{Directions back to Nashville}

-Follow TN-285 W to TN-111 N: $1.45 \mathrm{~km}(0.9 \mathrm{mi})$

-Follow TN-111 N to I-40: $41.5 \mathrm{~km}(25.8 \mathrm{mi})$

-Follow I-40 W to Nashville: $127 \mathrm{~km}(79 \mathrm{mi})$

\section{References}

Anderson, C., and Kambesis, P., 1992, Cave map of The Gouffre: Tennessee Cave Survey, Nashville, Tennessee, unpublished map.

Crawford, N., 1973a, Cave map of Devilstep Hollow Cave: Tennessee Cave Survey, Nashville, Tennessee, unpublished map.

Crawford, N., 1973b, Cave map of Mill Cave: Tennessee Cave Survey, Nashville, Tennessee, unpublished map.
Crawford, N.C., 1982, Karst hydrogeology of TennesseeGuidebook for karst hydrogeology workshop:

U.S. Environmental Protection Agency, Groundwater Section, Region IV, $102 \mathrm{p}$.

Crawford, N.C., 1987, The karst hydrogeology of the Cumberland Plateau Escarpment of TennesseeSubterranean stream invasion, conduit cavern development, and slope retreat in the Lost Creek Cove area, White County, Tennessee: Tennessee Department of Conservation, Division of Geology, no. 44, part 1.

Crawford, N.C., 1989, The karst hydrogeology of the Cumberland Plateau Escarpment of Tennessee: Karst valley development and the headward advance of the Sequatchie Valley in the Grassy Cove area, Cumberland County, Tennessee: Tennessee Department of Conservation, Division of Geology. no. 44, part 2.

Cumberland Trails Conference, 2020, The Cumberland Trails Conference: Tennessee Department of Environment and Conservation, website accessed January 6, 2020, at www.cumberlandtrail.org. 
Garman, R.K., 1969, Geologic map and mineral resources summary of the Monterey Lake quadrangle: Tennessee Division of Geology Geologic Quadrangle Map 331 SE, scale 1:24,000.

Green, M., and Miller, B., 2014, Tennessee's hidden mystery, in Guidebook for the 2014 NSS Convention in Huntsville, Alabama: Huntsville, Alabama, National Speleological Society, p. 80-92.

Jones, S., 2001, Following the water in the Falling Water River, in Proceedings of the Tennessee Water Resources Symposium, 11th, Burns, Tennessee, 2001: Tennessee Section of the American Water Resources Association, p. P-2-P-5.

Jones, S., Hoffelt, J., Anderson, S., Love, H., and Bailey, J., 2002, Karst hydrogeology of Spencer Mountain, Van Buren County, Tennessee, in Proceedings of the Tennessee Water Resources Symposium, 12th, Burns, Tennessee, 2002: Tennessee Section of the American Water Resources Association, p. 2A-34-2A-39.

Lane, B., 1979, Cave map of Run to the Mill Cave: Tennessee Cave Survey, Nashville, Tennessee, unpublished map.

Love, H., Swartz, J., Hoffelt, J., Hardin, M., and Bailey, J., 2002, Karst hydrogeology_-Spencer Mountain, Van Buren County, Tennessee: Unpublished map.

Milici, R.C., 1965, Geologic map and mineral resources summary of the Grassy Cove quadrangle: Tennessee Division of Geology Geologic Quadrangle Map 117 SW, scale 1:24,000.

Milici, R.C., 1968, The physiography of Sequatchie Valley and adjacent portions of the Cumberland Plateau, Tennessee: Tennessee Division of Geology Report of Investigations 22, $15 \mathrm{p}$.

Miller, B., 2016, Cave map of Head of Sequatchie Spring Cave: Tennessee Cave Survey, Nashville, Tennessee, unpublished map.
Moore, J.L., and Milici, R.C., 1990, Geologic map and mineral resources summary of the Vandever quadrangle: Tennessee Division of Geology Geologic Quadrangle Map $109 \mathrm{SE}$, scale 1:24,000.

Palmer, A.N., and Palmer, M.V, 2009, Geology of Tennessee, in Caves and karst of the USA: Huntsville, Alabama, National Speleological Society, p. 80-82.

Simek, J.F., Cressler, A., Faulkner, C.H., Ahlman, T.M., Creswell, B., and Franklin, J.D., 2001, The context of late prehistoric cave art-The art and archaeology of 11th Unnamed Cave, Tennessee: Southeastern Archaeology, v. 20 , no. 2 , p. 142-153.

Sims, J., 1977, Cave map of Grassy Cove Saltpetre Cave: Tennessee Cave Survey, Nashville, Tennessee, unpublished map.

Sims, J., and Sims, M., 1978, Cave map of the Lost Creek Cave System: Tennessee Cave Survey, Nashville, Tennessee, unpublished map.

Smith, M.O., 2017, The discovery and exploration of Rumbling Falls Cave: Unpublished document, 134 p.

Smyre, J., 2008, Cave map of Rice Cave: Tennessee Cave Survey, Nashville, Tennessee, unpublished map.

Steinmann, H., 2018, Controls on speleogenesis in the Upper-Mississippian Pennington Formation on the Western Cumberland Plateau Escarpment: Bowling Green, Western Kentucky University, Master's thesis, 124 p., https://digitalcommons.wku.edu/theses/3088.

Swartz, J., 2002, Cave map of Rumbling Falls Cave: Tennessee Cave Survey, Nashville, Tennessee, unpublished map.

Tennessee Cave Survey, 2019a, Cave location database: Tennessee Cave Survey database, http://www.subworks.com/tcs/contacts.html.

Tennessee Cave Survey, 2019b, Narrative file descriptions of White County caves: Tennessee Cave Survey database, unpublished digital data, http://www.subworks.com/tcs/ contacts.html. 

For more information concerning the research in this report, contact Water Availability and Use Science Program Coordinator Water Resources Mission Area

U.S. Geological Survey

12201 Sunrise Valley Drive

Mail Stop 415

Reston, VA 20192 


\section{$\frac{\mathbb{2}}{3}$}

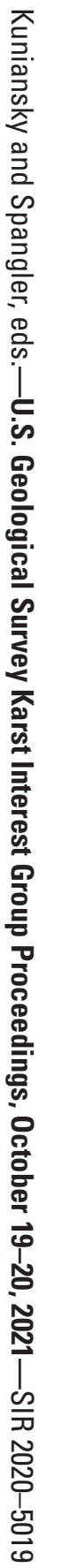

